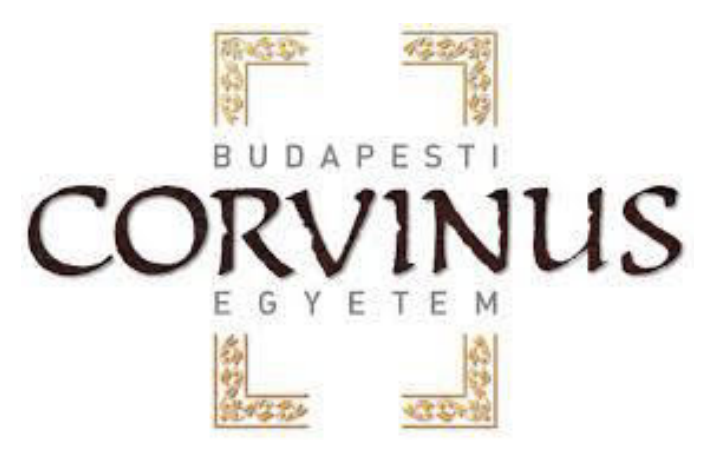

\title{
Reverz hidrolízis és transzglikoziláció tanulmányozása oligoszacharidok szintézisére
}

\author{
Doktori értekezés
}

Styevkó Gabriella

Témavezetők: Dr. Habil. Nguyen Duc Quang egyetemi docens Prof. Dr. Hoschke Ágoston professzor emeritus

\section{Budapest}




\section{A doktori iskola}

megnevezése: Élelmiszertudományi Doktori Iskola

tudományága: Élelmiszertudományok

vezetője:

Dr. Felföldi József

egyetemi tanár, $\mathrm{PhD}$

Budapesti Corvinus Egyetem, Élelmiszertudományi Kar

Fizika-Automatika Tanszék

Témavezetők: $\quad$ Dr. Habil. Nguyen Duc Quang

egyetemi docens, $\mathrm{PhD}$

Prof. Dr. Hoschke Ágoston

professzor emeritus, CSc

Budapesti Corvinus Egyetem, Élelmiszertudományi Kar

Sör- és Szeszipari Tanszék

A jelölt a Budapesti Corvinus Egyetem Doktori Szabályzatában elöírt valamennyi feltételnek eleget tett, a mühelyvita során elhangzott észrevételeket és javaslatokat az értekezés átdolgozásakor figyelembe vette, ezért az értekezés nyilvános vitára bocsátható. 
A Budapesti Corvinus Egyetem Élettudományi Területi Doktori Tanácsának 2015. június 9-i határozatában a nyilvános vita lefolytatására az alábbi bíráló Bizottságot jelölte ki:

\section{BÍRÁLÓ BIZOTTSÁG:}

\section{Elnöke}

Biacs Péter, DSc

\section{Tagjai}

Stefanovitsné Bányai Éva, DSc

Halász Anna, DSc

Amtmann Mária, $\mathrm{PhD}$

Gelencsér Éva, CSc

Opponensek

Gyémánt Gyöngyi, PhD

Simonné Sarkadi Livia, DSc

Titkár

Kun Szilárd, PhD 


\section{Tartalomjegyzék}

1 BEVEZETÉS ÉS CÉLKITÜZÉS ........................................................ 1

2 IRODALMI ÁTTEKINTÉS …............................................................................. 5

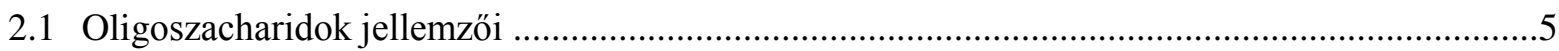

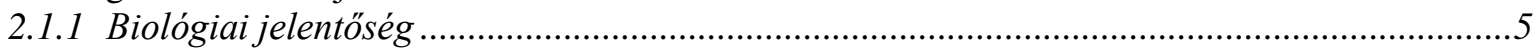

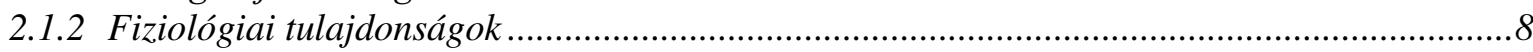

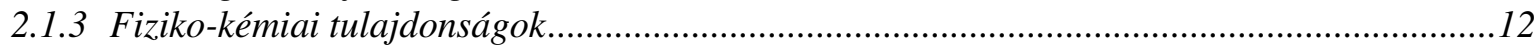

2.2 Oligoszacharidok elóállítása fizikai és kémiai módszerekkel .................................................13

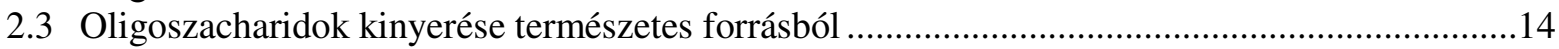

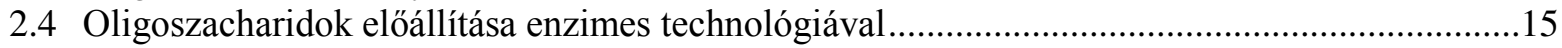

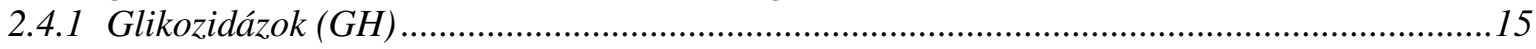

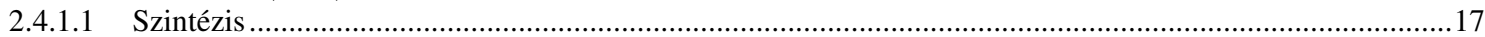

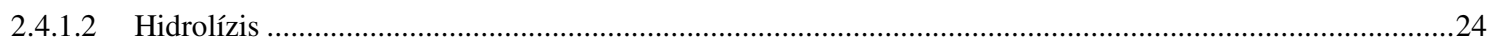

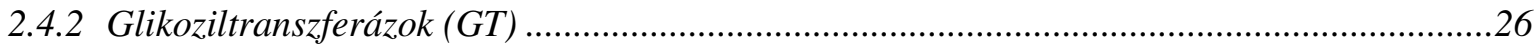

2.4.2.1 Szintézis non-Leloir glikoziltranszferázokkal ................................................................................

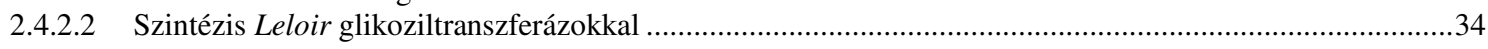

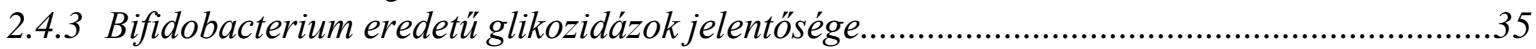

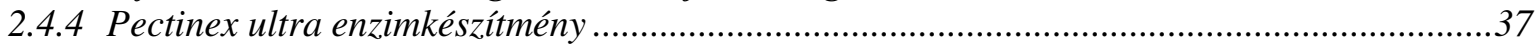

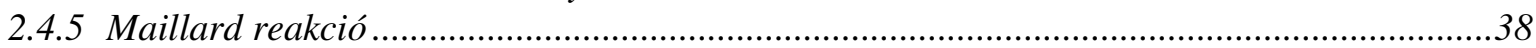

3 ANYAGOK ÉS MÓDSZEREK...................................................................... 41

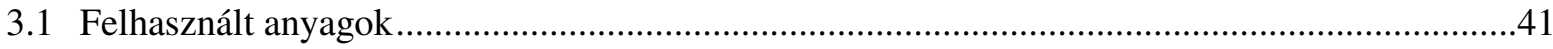

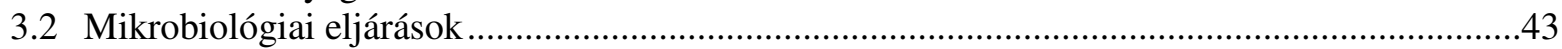

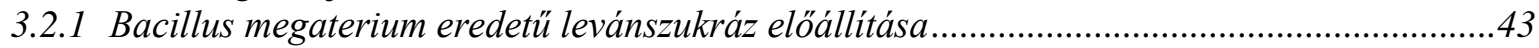

3.2.2 Bifidobacterium longum eredetü enzimpreparátum elöállitása.............................................43

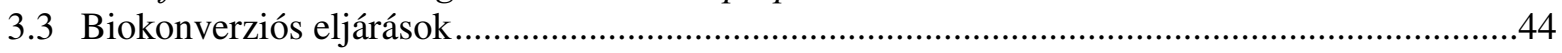

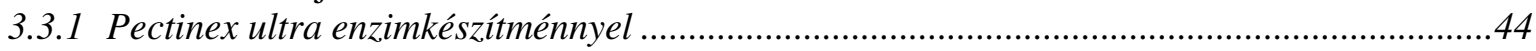

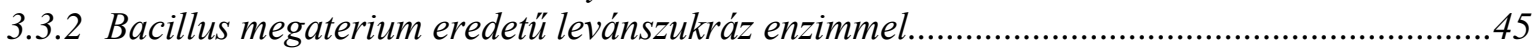

3.3.3 Bifidobacterium longum eredetü enzimpreparátummal .......................................................45

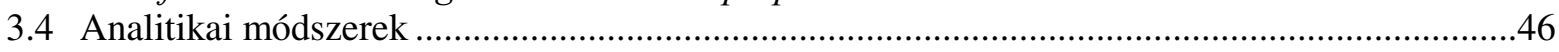

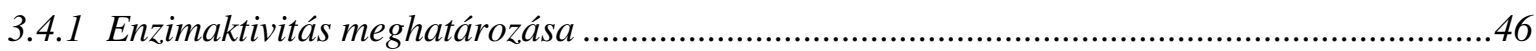

3.4.1.1 A Pectinex utra és a Bifidobacterium longum eredetủ preparátum aktivitásainak meghatározása ...................46

3.4.1.2 Bacillus megaterium eredetủ levánszukráz akvitásának meghatározása .........................................................48

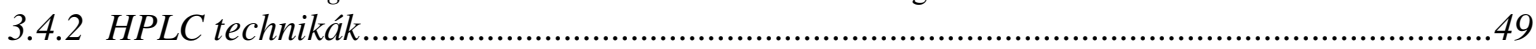

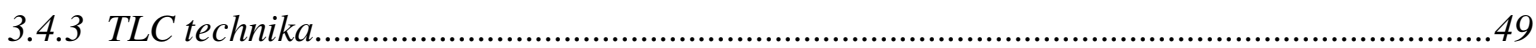

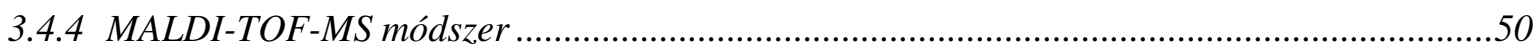

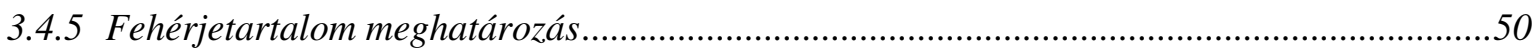

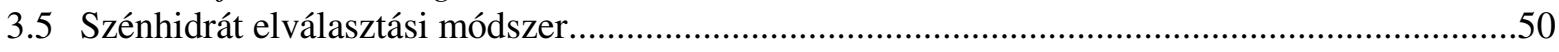

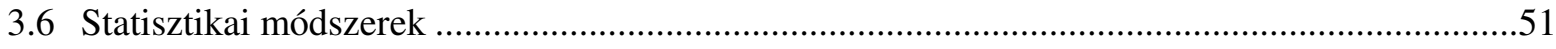

4 KÍSÉRLETI EREDMÉNYEK ÉS ÉRTÉKELÉSÜK ............................. 53

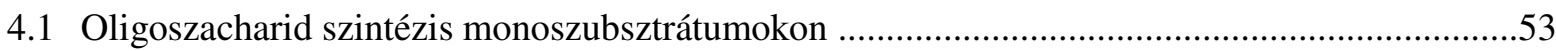

4.1.1 Transzglikoziláció Pectinex ultra enzimkészitménnyel .........................................................53

4.1.1.1 Glükozil-glükózok ...................................................................................................................5

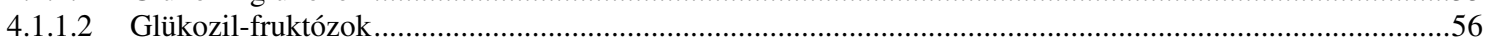

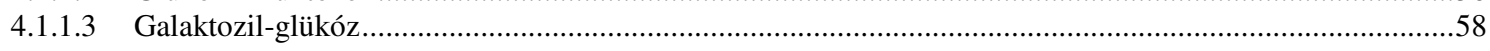

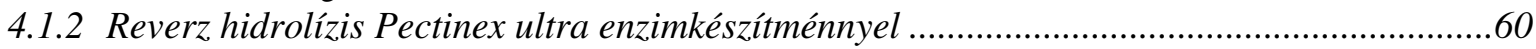

4.1.3 Transzglikoziláció Bifidobacterium longum eredetü enzimpreparátummal ...........................61

4.1.4 Különbözö paraméterek hatása a mannóz alapú di/oligoszacharidok szintézisére.................63

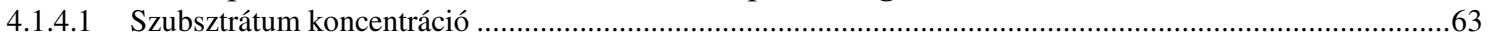

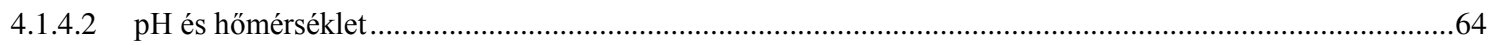

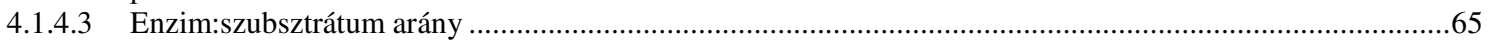

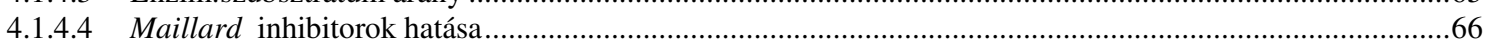

4.1.5 A mannóz alapú di/oligoszacharidok elválasztása és jellemzése............................................67

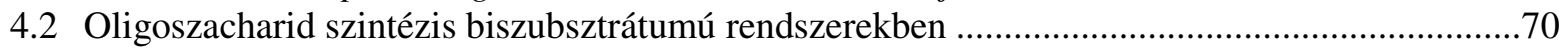

4.2.1 Reverz hidrolizis Pectinex ultra enzimkészítménnyel ...........................................................70

4.2.2 Transzglikoziláció Pectinex ultra enzimkészítménnyel ..........................................................72 


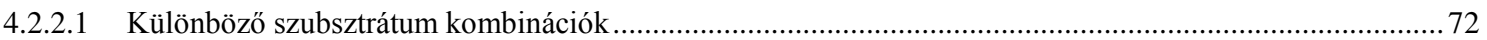

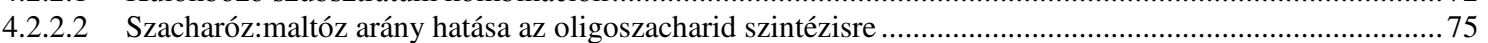

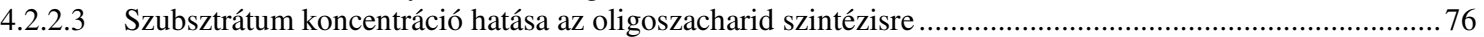

4.2.3 Transzglikoziláció Bacillus megaterium eredetü levánszukráz enzimmel ............................ 77

4.2.4 Transzglikoziláció Bifidobacterium longum eredetü preparátummal.................................. 80

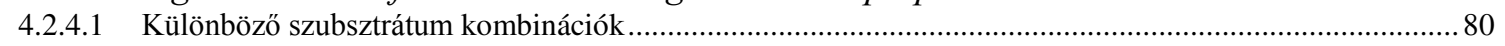

4.2.4.2 Optimális szubsztrátum koncentráció és szubsztrátum:szubsztrátum arány ............................................. 81

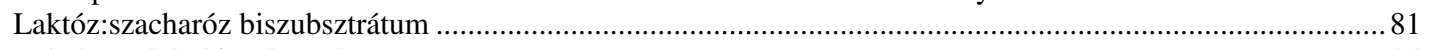

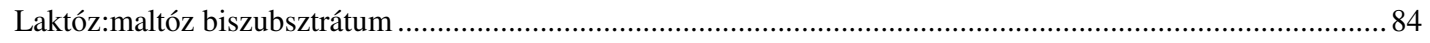

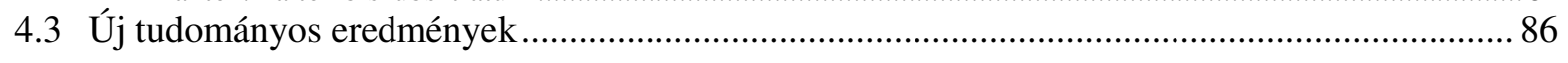

$5 \quad$ KÖVETKEZTETÉSEK ÉS JAVASLATOK..........................................89

6 ÖSSZEFOGLALÁS ...................................................................................91

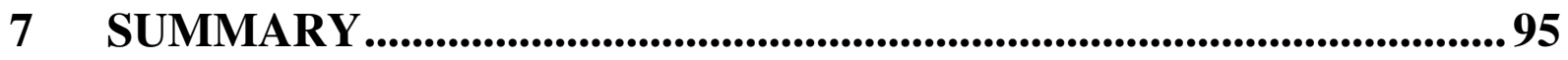

8 IRODALOMJEGYZÉK .......................................................................99

9 PUBLIKÁCIÓS JEGYZÉK............................................................................ 113 


\section{RÖVIDÍTÉSEK JEGYZÉKE}

AG:

AGE:

Asp:

BSA:

CMP

FOS:

GDP:

$\mathrm{GH}$ :

GlOS:

Glu:

GOS:

GT:

HMO:

HPAEC-PAD:

HPLC:
Aminoguanidine hydrochloride, aminoguanidin-hidroklorid

Advanced glycation endproduct, Elörehaladott glikációs végtermékek

Asparagine acid, Aszparaginsav

Bovine serum albumin, Marha szérum albumin

Citozine-monophosphate, Citozin-monofoszfát

Fructooligosaccharide, Frukto-oligoszacharid

Guanidine-diphosphate, Guanidin-difoszfát

Glycosyl hydrolase, Glikozil hidroláz

Glucooligosaccharide, Glüko-oligoszacharid

Glutamic acid, Glutaminsav

Galactooligosaccharide, Galakto-oligoszacharid

Glycosyltransferase, Glikoziltranszferáz

Human Milk Oligosaccharide, Anyatej-oligoszacharid

High performance anion exchange chromatography,

Pulsed amperometric detector, Nagyhatékonyságú anioncserélő kromatográfia - Pulzáló amperometriás detektor

High performance liquid chromatography,

Nagyhatékonyságú folyadék kromatográfia

MALDI-TOF-MS: Matrix assisted laser desorption ionisation - Time of flight-

Mass spectrometry, Mátrix által segített lézer deszorpció ionizáció

- Repülési idő - Tömegspektrometria

NDO:

Non-digestible oligosaccharide, Nem emészthető oligoszacharid

OPD:

o-phenylene-diamine-dihydrochloride,

o-fenilén-diamin-dihidroklorid

OS:

Oligosaccharide, Oligoszacharid

SCFA:

Short chain fatty acid, Rövid szénláncú zsírsav

SMC:

Semicarbazide-hydrocloride, Szemikarbazid-hidroklorid

TDP:

Timidine-diphosphate, Timidin-difoszfát

TLC:
Thin layer chromatography, Vékonyréteg kromatográfia 


\section{BEVEZETÉS ÉS CÉLKITƯZÉS}

A szénhidrátok fontos és meghatározó szerepet játszanak az élővilágban. E biomolekulák számos biológiai funkcióval rendelkeznek: energia ellátás (pl. glükóz), tápanyagok tartalékolása (pl. keményítő, glikogének, stb.), építőanyagok (pl. cellulóz, kitin), nukleotidoknak, koenzimeknek stb. fontos komponensei. A szénhidrátok összetételüket és szerkezetüket tekintve sokfélék lehetnek. A polimerizáltsági fok alapján négy csoportra oszthatók: monoszacharidok, diszacharidok, oligoszacharidok (3-10 tagszámú) és poliszacharidok (10-nél nagyobb tagszámú). Az oligoszacharidok (OS) a szénhidrátok egyik fontos csoportja, melyek meghatározó szerepet játszanak a biológiai rendszerekben, pl. részt vesznek különböző felismerési folyamatokban, nagy szerepük van a sejtek szervezési és védelmi mechanizmusában, hatásuk lehet a fehérjék biológiai funkciójára stb. Továbbá a kedvező fiziko-kémiai, fiziológiai és technológiai tulajdonságuk miatt az élelmiszeriparban is széleskörüen alkalmazzák. Egyes oligoszacharidokat a bennük lévő speciális glikozidos kötéseknek köszönhetően az emésztőrendszer enzimei nem képesek lebontani (nem-emészthető oligoszacharidok), melyek így diabetikus vagy alacsony kalóriatartalmú termékek gyártására használhatók. Emellett prebiotikus hatásúak is lehetnek, azaz kedvezően támogathatják a vastagbélben élő jótékony hatású mikroorganizmusok szaporodását, illetve aktivitását. Ezeket funkcionális élelmiszerek összetevőjeként széleskörüen alkalmazzák.

Az előállításuk különböző eljárásokkal történhet: kémiai, fizikai vagy enzimes úton. Oligoszacharidokhoz juthatunk természetes forrásból történő kinyeréssel is. A kémiai eljárás bonyolult és költséges folyamat, nehéz a léptéknövelés megoldása, valamint nagy a melléktermék képződésének kockázata. A fizikai oligoszacharid előállítási módszerek hátránya, hogy nem specifikusak, így alkalmazásuk korlátozott. A fizikai és kémiai előállítással szemben az enzimes módszerek nagy előnye, hogy a régio- és sztereospecifitásnak köszönhetően szabályozható a termékspektrum, minimális a melléktermék képződés lehetősége, emellett változatos reakciókörülmények között is megvalósítható a biokonverzió. A felsorolt indokok miatt az enzimes szintézist részesítik előnyben. Jelenleg számos kereskedelemben kapható prebiotikus oligoszacharidot (pl. GOS, FOS) kizárólag enzimes technológiával állítanak elő. Az oligoszacharidok enzimes előállításának különböző módjai lehetnek: poliszacharidok enzimes hidrolízise, transzglikoziláció és reverz hidrolízis reakciók. Számos enzim (hidrolázok, glikoziltranszferázok, glikoszintázok) képes szintézis reakció katalizálására, amellyel célzott összetételü/szerkezetetü oligoszacharidok állíthatók elő, akár mono- akár biszubsztrátum rendszerekben. Vannak köztük olyan enzimek, amelyek katalitikus mechanizmusáról még kevés információ áll rendelkezésünkre. Ezen enzimek katalitikus aktivitásának megismerésével pedig 
lehetőségek nyílhatnak új technológiák alkalmazására, vagy akár új oligoszacharidok előállítására.

E kutatási területhez kapcsolódva doktori kutatómunkámban különböző eredetü enzimpreparátumok transzglikozilációs és reverz hidrolitikus hatásait tanulmányoztam mono- és biszubsztrátum rendszerekben. A szintetizált oligoszacharidok, valamint az enzimek katalitikus hatásának tanulmányozásából származó eredmények bővíthetik a tudományos alapismereteket, hozzájárulhatnak az enzimek hatásmechanizmusainak megértéséhez, biológiai funkciók (működés és szabályozás) feltárásához, továbbá kívánt funkciójú vagy szerkezetü termék(ek) előállítására szolgáló enzimes technológiák kidolgozásához.

\section{Célkitűzések:}

- Célom volt a kereskedelmi Pectinex ultra ipari enzimkészítményben található kísérő enzimek vizsgálata és ezek oligoszacharid szintetizáló mechanizmusának igazolása különböző szubsztrátumokon. A Pectinex ultra egy pektinbontás céljára kifejlesztett fonalas gomba (Aspergillus aculeatus) eredetü ipari készítmény, amely számos kísérő enzimmel rendelkezik. Számos irodalmi adat áll rendelkezésre, hogy kísérő enzimeivel oligoszacharidok szintetizálhatók.

Ennek igazolására tanumányoztam az alábbi enzimes folyamatokat :

○ Transzglikoziláció diszacharid szubsztrátumokon

○ Reverz hidrolízis monoszacharid szubsztrátumokon

- Célom volt a Pectinex ultra enzimkészítmény alkalmazásával a mannóz alapú (di-, oligo)szacharidok szintézisének tanulmányozása. A manno-oligoszacharidok biológiai szerepe jelentős. Számos glikoprotein építőkövei, és bizonyítottan tapadásgátló tulajdonsággal rendelkeznek.

A kisérleti terv megvalósítására az alábbi részfeladatokat végeztem:

○ Szubsztrátum koncentráció hatása

○ pH és hőmérséklet hatása

○ Optimális enzim:szubsztrátum arány

○ Maillard inhibició vizsgálata

○ A mannóz alapú (di, oligo) szacharidok tisztítása és jellemzése 
- Céljaim között szerepelt egy Bifidobacterium longum Bb-46 eredetű enzimpreparátum transzglikozilezési tulajdonságainak vizsgálata különböző diszacharidokon. A bifidobaktérium eredetü enzimek felé egyre nagyobb figyelem irányul. Ennek oka, hogy a Bifidobacterium eredetü enzimmel elöállított prebiotikus szénhidrátot a probiotikus mikroorganizmusok könnyebben hasznosíthatják.

- Egyes enzimek által katalizált reverz hidrolízis vagy transzglikozilációs reakciójában többféle donor/akceptor molekula részt vehet. Az enzimek e specifitásának ismeretében lehetőség van akár új oligoszacharidok szintézisére is. Ennek meghatározására célul tüztem ki két-szubsztrátumos rendszerek tanulmányozását a következő részfeladatokkal:

○ Pectinex ultra enzimkészítmény vizsgálata biszubsztrátumok esetében

- Reverz hidrolízis vizsgálata különböző monoszacharid kombinációk esetében

- Transzglikozilációs reakciók vizsgálata különböző diszacharid kombinációk esetében

○ Bacillus megaterium DSM 319 eredetü rekombináns levánszukráz enzim tanulmányozása biszubsztrátum rendszerekben

○ Bifidobacterium longum $\mathrm{Bb}-46$ eredetű preparátum transzglikozilációs reakcióinak vizsgálata biszubsztrátum rendszerekben 
DOI: 10.14267/phd.2015034 


\section{IRODALMI ÁTTEKINTÉS}

\subsection{Oligoszacharidok jellemzői}

A szénhidrátok molekulaméretük illetve polimerizáltságuk alapján négy csoportba oszthatók: monoszacharidok, diszacharidok, oligoszacharidok és poliszacharidok. Az oligoszacharidok olyan összetett szénhidrátok, amelyek az IUB-IUPAC (International Union of Pure and Applied Chemistry) szerint 3-10, más szerzők szerint 3 - 19 monoszacharid egységből épülnek fel (MussatTo \& MANCILHA, 2007; WeIJers et al., 2008). Ezen meghatározások azonban nem racionális fiziológiai vagy kémiai tulajdonságokon alapulnak, ugyanis néhány diszacharid (pl. laktulóz) hasonló biológiai tulajdonságokat mutat mint a nagyobb polimerizáltságú szénhidrátok, és fontos szerepet játszanak az élelmiszergyártásban. Az oligoszacharidok kis molekulatömegű szénhidrátok, és fiziológiai tulajdonságaik alapján az emészthető és nem emészthető kategóriába sorolhatók (CRITTENDEN \& PlAYNE, 1996; HiRAYAMA, 2002; MusSATto \& MANCILHA, 2007).

\subsubsection{Biológiai jelentöség}

A szénhidrátok a biomolekulák egy jelentős osztályát képezik, amelyeknek fontos szerepe van a biológiai folyamatokban. Kétségkívül a szénhidrátok kulcsfontosságú energiaforrásként szolgálnak, és szerkezeti polimer szerepet is betöltenek. Továbbá, a szénhidrátok (poliszacharidok vagy glikokonjugátumok) minden sejt felületén és extracelluláris állományban megtalálhatók.

Az oligoszacharidok a természetben előforduló szénhidrátok egyik nagy csoportja, amelyek biológiai szerepe jelentős (bioaktív komponensek).

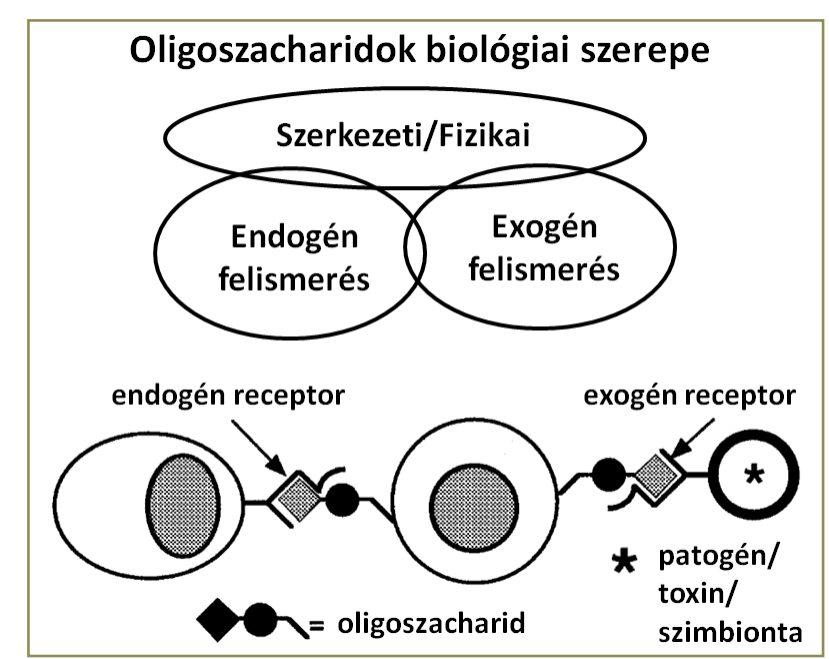

1. ábra: Oligoszacharidok biológiai szerepe (GAGNEUX \& VARKI, 1999) 
Biológiai funkciójuk szerint két nagy csoportra oszthatók (1. ábra):

1. elsődlegesen szerkezeti és fizikai szereppel rendelkező oligoszacharidok

2. felismerési folyamatok résztvevői (ez a csoport 2 alcsoportra osztható)

a. önfelismerő (,self recognition”) folyamatok résztvevői,

b. nem önfelismerő (,non-self recognition”) folyamatok résztvevői:

E folyamatokban föként mikroorganizmus vagy parazita receptorok vesznek részt, de a szimbiózisért (pl. a bélbaktréiumok megtelepedéséért) is e csoport felelhet (GAGNEUX \& VARKI, 1999).

E szénhidrátok nem csak specifikus felismerő folyamatok közvetítői, hanem képesek számos biológiai folyamat befolyásolására is. Emellett ezek a molekulák nagy szerepet játszanak a biológiai anyagok (glikokonjugátumok) hatalmas szerkezeti diverzitásában, mely elengedhetetlen a komplex organizmusok fejlődéséhez, differenciálódásához illetve más szervezetekkel való kölcsönhatásához (VARKI, 1993). Számos oligoszacharidnak, proteoglikánnak, kollagénnek nagy szerepe van a szövetek szerkezetének integritásában, porozitásában és fizikai védelmében. A glikoproteinek felületén lévő oligoszacharidok megvédhetik a polipeptid láncokat attól, hogy a proteázok vagy antitestek felismerjék a molekulát, így megakadályozzák azok lebontását. A glikánok közvetlen hatással lehetnek a fehérjék negyedleges és másodlagos szerkezetére is azáltal, hogy az endoplazmatikus retikulumban hozzájárulnak a polipeptidek helyes feltekeredéséhez. Emellett segítik a fehérjék oldhatóságának és konformációjának megtartását (VARKI, 1993; WORMALD \& DWEK, 1999; PARODI, 2000).

Az extracelluláris mátrix glikokonjugátumok széles köréből tevődik össze. Minden glikokonjugátum rendelkezik olyan kötő hellyel, amellyel különböző típusú cukorláncokat képesek megkötni, pl. a fibronektin és a kollagén heparin-kötő domain-nel rendelkeznek (VARKI, 1993). Ennek köszönhetően nagy szerepük van a sejtek szervezési és védelmi funkciójában.

Tekintettel a sejtfal összetételére, már régóta feltételezték, hogy az oligoszacharidok meghatározó szerepet játszanak a sejt-sejt és a sejt-mátrix interakciókban. Egyes oligoszacharidok nagy specifitású receptorként viselkedhetnek különböző vírusok, baktériumok és paraziták számára. Emellett receptorok lehetnek növényi és bakteriális toxinok részére, valamint antigénként is szerepelhetnek különböző autoimmun és alloimmun reakciókban. A legtöbb ilyen reakcióban fontos szerepet játszik a résztvevő oligoszacharid szekvenciája. Ez a specifitás előnyös azon kutatók számára, akik e cukorláncok expresszióját tanulmányozzák (VARKI, 1993). Továbbá meghatározott szénhidrátok nem csak receptorként szerepelhetnek különböző mikrobiális fertőzésekben és immunreakciókban, hanem azok megszüntetésében is részt vehetnek. Ebben az esetben különböző specifikus monoszacharidok hozzáadásával vagy az 
oligoszacharid szekvenvencia módosításával elkerülhető, hogy a mikroorganizmusok azt receptorként ismerjék fel. Erre példa az $O$-acetil-észter hozzákapcsolása a terminális sziálsav kilences pozíciójához, mellyel megakadályozható az influenza A vírus megkötődése (ZoPF \& RоTH, 1996).

Az oligoszacharidok egyes oldható glikokonjugátumokon (pl. a mucinon) viselkedhetnek úgynevezett „,csali” szénhidrátként is a mikroorganizmusok és paraziták ellen. E védekező mechanizmus során a patogén mikroorganizmus, amikor megkísérel átjutni a nyálkahártya membránokon elöször a rokon oligoszacharid ligandummal találkozik (2. ábra), melyhez hozzákapcsolódva már nem tud a nyálkahártya sejtjeihez kapcsolódni, megakadályozva ezzel a szervezet megbetegedését (CHEN et al., 1993; ZoOPF \& RoOTH, 1996).

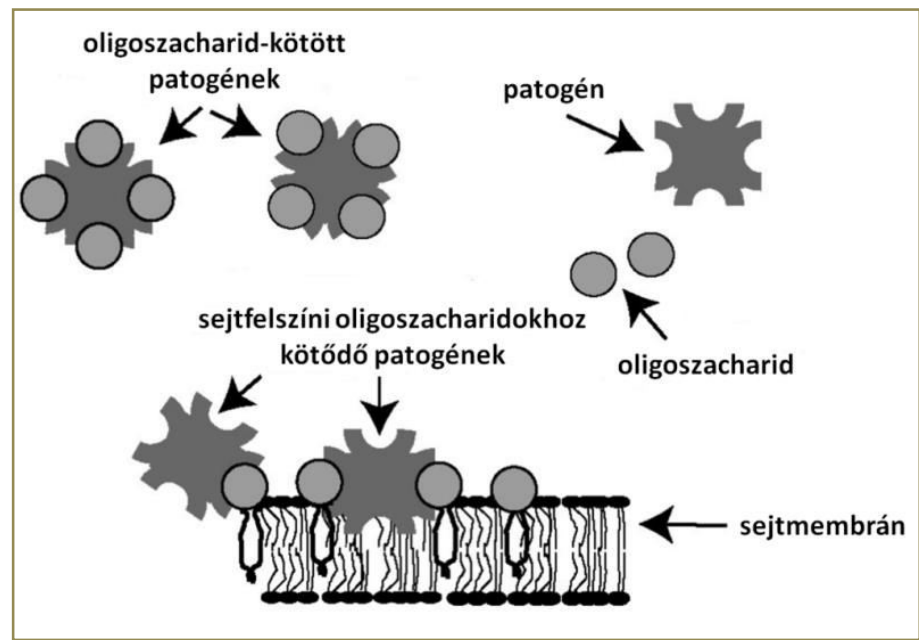

\section{2. ábra: Patogének megtapadásának gátlása oligoszacharidokkal (PRIETO, 2005)}

Specifikus oligoszacharidok kölcsönhatásával szimbiotikus kapcsolatok is létrejöhetnek. Erre példa egyes bélbaktériumok jelenléte az állati szervezetekben (SERVIN \& COCCONIER, 2003), vagy a gyökérgümőt létrehozó ( $\mathrm{N}_{2}$-kötő) baktériumok és a gazdanövény között létrejövő kapcsolat (STAEHELIN et al., 2006), ez az oligoszacharidok által nyújtott fajok közötti felismerés mindkét résztvevő szervezet számára hasznos.

E szénhidrátoknak hatása lehet a fehérjék biológiai funkciójára is. Számos példa van, melyben a glikoziláció lényegesen módosítani tudja a peptidek rokon ligandumokkal vagy receptorokkal történő interakcióját (SELLERS et al., 1988; JENTOFT, 1990). A glikoziláció közvetítheti egy fehérjefunkció be-, kikapcsolását vagy átváltását.

Egyes biológiailag fontos molekulák számára az oligoszacharidok raktározási szerepet is betölthetnek. In vivo körülmények között bizonyították, hogy egyes növekedési faktorok specifikusan és erősen tudnak kötődni bizonyos glükózaminoglikán láncokhoz (MACH et al., 1993; DiGABRIELE et al., 1998). E kötődésnek köszönhető a növekedési faktor a sejtet körülvevő 
extracelluláris mátrixban való lokalizációja, amely fontos szerepet játszik a stimulálásban, és megakadályozza a sejttől távol eső térbe történő diffúzióját. Továbbá megvédi a növekedési faktort a nem-specifikus proteolízistől is, így segíti megőrizni aktivitását. A szekréciós granulumokban található glükózaminoglikán láncnak pedig a kiválasztott fehérje védelmében és annak szabályozásában van fontos szerepe.

A sejtek intracelluláris és intercelluláris anyagcseréjében szintén részt vehetnek az oligoszacharidok. Az intracelluláris funkció egyik példája a frissen szintetizált lizoszómális enzimek mannóz-6-foszfát végének szerepe az enzimek végső helyükre történő eljutásában (VARKI, 1993). Az intercelluláris anyagcsere során a glikolizáció a sejtekben lévő fehérjék kicserélődésére és felezési idejére is hatással lehet. Az ép állati szervezetekben egyes receptorok által felismert oligoszacharid szekvenciák a glikokonjugátum vagy akár az egész sejt keringésből történő eltávolítását jelentheti. A legtöbb ilyen típusú interakció specifikus a receptor által felismert oligoszacharid szekvenciájára.

Egyes oligoszacharidok önmagukban is rendelkezhetnek biológiai hatással. Ezek a hormonszerü szénhidrátok („oligoszacharinok”) védekezési reakciót aktiválhatnak, és részt vehetnek pl. növényi szövetek növekedésének és differeciálódásának szabályozásában (TSAVKELOVA et al., 2006; ENRíQUEZ-GUEVARA et al., 2010). A szabad hosszúláncú manno-oligoszacharidok is jelentősek e szempontból. E molekuláknak in vitro erős immunszupresszív hatása van az emlős szervezetekre (MUCHMORE et al., 1990; VARKI, 1993).

\subsubsection{Fiziológiai tulajdonságok}

Az oligoszacharidok kedvező fizikokémiai jellemzőkkel rendelkeznek de jótékony fiziológiai tulajdonságuk miatt alkalmazzák széles körben élelmiszerösszetevőként.

A keményítővel és az egyszerü cukrokkal ellentétben, néhány oligoszacharidot a száj mikroflórája (pl. Streptococcus mutans) nem hasznosít, ezáltal nem okoznak fogszuvasodást (PRAPULLA et al., 2000). Ennek köszönhetően jól alkalmazhatók cukorhelyettesítőként cukrászati termékekben, rágógumikban, joghurtokban és üdítőitalokban.

Egyes oligoszacharidokat az emberi szervezet, bizonyos enzimek hiánya miatt nem képes megemészteni. Ezek a nem-emészthető oligoszacharidok (NDO). Általában édeskések, kis kalóriatartalmúak, így a diétázók illetve a cukorbetegek is fogyaszthatják (CRITTENDEN \& PLAYNE, 1996). Emészthetetlenségük miatt képesek épségben eljutni a vastagbélbe, és így egyes anaerob baktériumok számára szubsztrátumok. A fermentáció során energia forrást jelentenek a baktériumok szaporodásához, és a folyamat során a szervezet számára nem hasznosítható gázok $\left(\mathrm{H}_{2}, \mathrm{CO}_{2}, \mathrm{CH}_{4}\right)$, valamint rövidláncú zsírsavak (pl. acetát, a propionát, a butirát és az L-laktát) 
termelődnek (LOO et al., 1999). A nem-emészthető és emészthető oligoszacharidok metabolizmusát a 3. ábra szemlélteti.

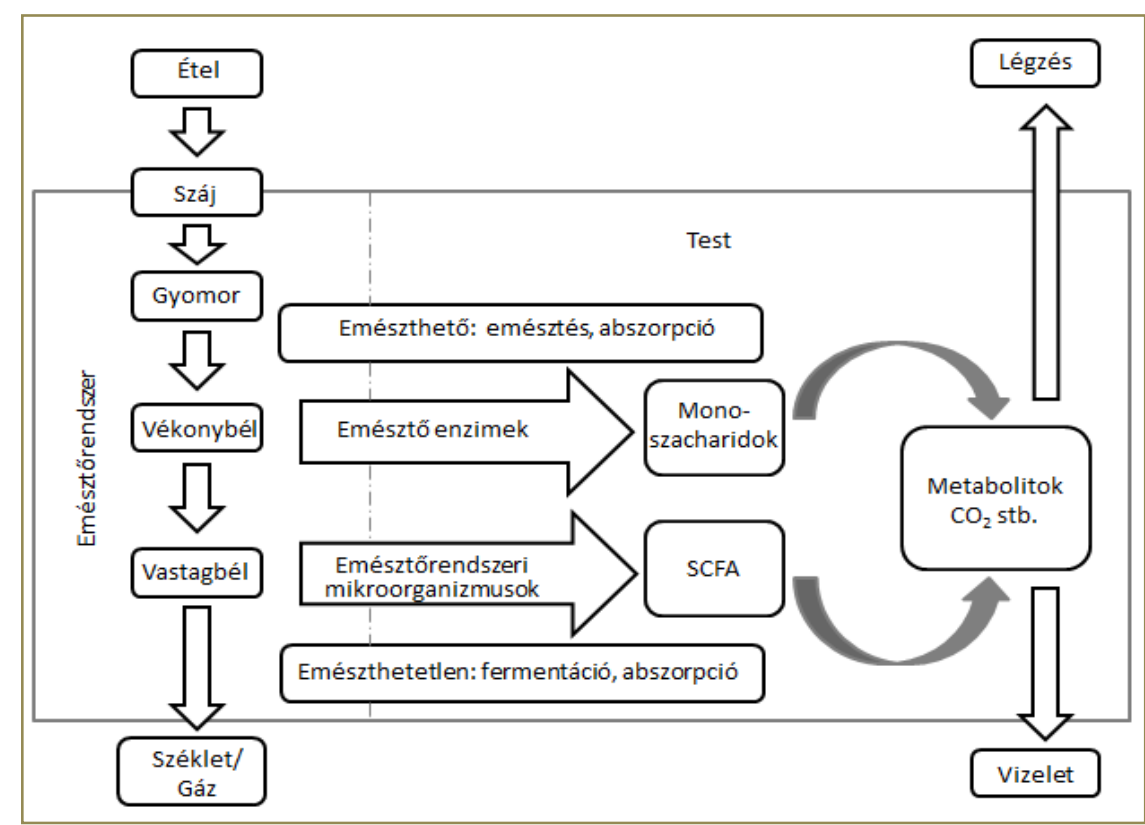

3. ábra: Az emészthető és nem-emészthető szénhidrátok anyagcsere folyamatának különbségei (HIRAYAMA, 2002)

A NDO-ok bár nem látják el a szervezetet monoszacharidokkal, indirekt energiaforrásként szolgálnak és anyagcsereszabályozó szerepet töltenek be. A vastagbélben termelődő rövidláncú zsírsavak mennyisége és típusa függ a NDO típusától, valamint a vastagbél mikroflórájának összetételétől (SAKO et al., 1999). Az emésztőrendszerben rendkívül sok, föleg obligát anaerob baktérium van jelen. Ez a mikrobiális közösség rendkívül összetett, mind a mikroorganizmusok számát (hozzávetőlegesen $10^{13}$ sejt), mind azok sokféleségét (400 - 500 különböző faj) tekintve (MusatTo \& MANCILHA, 2007). E mikroorganizmusok közül bizonyos fajok hasznosak a szervezet számára, egyes fajok azonban patogének, akut és krónikus betegségek kiváltó okai lehetnek. Kémiai szerkezetük miatt a NDO-okat csak korlátozott számú baktérium hasznosítja. A béltraktusban jelen levő baktériumok közül leginkább a bifidobaktériumok és lactobacillusok képesek az oligoszacharidokat hasznosítani, ezáltal kedvező hatást gyakorolni az emberi test müködésére (OKU \& NAKAMURA, 2002; MuSSATTO \& MANCILHA, 2007).

A vastagbélben az oligoszacharidok fermentálhatósága függ a polimerizációs foktól, a felépítő monoszacharidok glikozidos kötésétől és az elágazások mértékétől, a baktériumok közötti szinergiától, az oligoszacharid - baktérium - fermentációs termék kapcsolattól, a fermentáció természetétől és a szacharolitikus kapacitástól. A vastagbél baktériumai által végzett NDOhasznosítás a következő hatásokat gyakorolhatja a szervezetre: 
1. A vastagbél mikroflórájának módosítása: Az oligoszacharidok szubsztrátumként szolgálnak az anaerob baktériumok, föleg a bifidobaktériumok, növekedéséhez/szaporodásához/aktivitásához, ezáltal közvetetten gátolják a káros baktériumok tevékenységét. A csecsemők bélrendszerében kialakuló bifidomikroflóra pl. az anyatejben található galaktóz tartalmú oligoszacharidoknak köszönhető (BOUHNIK et al., 1999; LoO et al., 1999; Bode, 2006; MACFARLANE \& MACFARLANE, 2007; CRITTENDEN \& PLAYNE, 2009).

2. A vastagbél illetve a széklet pH-jának csökkentése: A vastagbélben történő oligoszacharid fermentáció során a keletkezett rövidláncú zsírsavak csökkentik a vastagbél illetve a széklet pH-ját. Az alacsony $\mathrm{pH}$ gátolja bizonyos patogén baktériumok növekedését, a bifidobaktériumok és a tejsavbaktériumok szaporodását azonban stimulálja (CAMPBELL et al., 1997; LOO et al., 1999; MuSSATTO \& MANCILHA, 2007).

3. Székrekedés enyhitése: A nem emészthető oligoszacharidok, az étkezési rostokhoz hasonlóan, megelőzik a székrekedést. A vastagbél baktériumai által végzett NDO fermentáció végtermékei a rövidláncú zsírsavak, amelyek eredményesen felszívódnak a humán vastagbél hámsejtjeiben, stimulálják azok növekedését, valamint a só és a víz felszívódását. Növelik az ozmotikus nyomást és ezáltal a széklet nedvességtartalmát (QIANG et al., 2009).

4. Tápanyagtermelés, mint például a $\mathrm{B}$ vitaminok $\left(\mathrm{B}_{1}, \mathrm{~B}_{2}, \mathrm{~B}_{6}, \mathrm{~B}_{12}\right.$, nikotinsav és folsav) szintézise (CASElATO DE SousA et al., 2011).

5. Hasmenés kialakulásának megelözése: E tulajdonságuk közvetlen összefüggésben állhat a bifidobaktériumok által, a $\mathrm{Gram}^{+}$és $\mathrm{Gram}^{-}$baktériumokra gyakorolt gátló hatásával (DEVRESE \& MARTEAU, 2007; QIANG et al., 2009).

6. Emésztőrendszeri, légzőszervi, húgyúti és ivarszervi fertözések megelözése azáltal, hogy gátolják a baktériumok megtapadását az epithel sejtek felületén (MUSSATTO \& MANCILHA, 2007; CRITTENDEN \& PLAYNE, 2009).

7. Ásványi anyagok felszívódásának indukálása (pl. vas, kalcium és magnézium): A nem emészthető oligoszacharidok által megkötött ásványi anyagok nem szívódnak fel, így elérik a vékonybelet, ahol a szénhidrát mátrixból felszabadulva szívódnak fel. A vastagbélben felszívódó kalcium nagymértékben csökkentheti a csontritkulás kialakulásának kockázatát és elősegíti a csontsűrüség és a csonttömeg növekedését (LOO, 2006; QIANG et al., 2009).

8. Szénhidrát és lipid anyagcserére gyakorolt jótékony hatás: Csökkentik a vér koleszterin, triglicerid és foszfolipid koncentrációját, ezáltal mérsékelve a diabétesz illetve az elhízás kialakulásának kockázatát. Egyes kutatók szerint a vérszérum koleszterin koncentrációja összefügg a bélmikroflóra változásaival. Egyes Lactobacillus acidophilus törzsek képesek 
asszimilálni a koleszterint, míg más mikrobák képesek a koleszterin bélfalon keresztüli felszívódását gátolni. Más vélemények szerint a lipidanyagcsere változása a máj metabolikus alkalmazkodásának következménye, amit a rövidláncú zsírsavak indukálnak. (Mussatto \& Mancilha, 2007; CRitTEnden \& Playne, 2009).

9. A rák (fóként a vastagbélrák) kockázatának csökkentése: Valószínüsíthető, hogy az oligoszacharidok antikarcinogén hatása összefüggésben van a sejtszintű immunitás növekedésével, a sejtfal összetételével és a bifidobaktériumok extracellulárisan termelt anyagaival. A széklet egyes fiziológiai paraméterei, pl. a pH, az ammónia, a p-krezol és az indol tartalom kockázati tényezőknek tekinthetők a vastagbélrák kialakulásánál. Humán kísérletekben bizonyították, hogy a transzgalaktozilált diszacharidok bevitele csökkenti a széklet pH-ját, az ammónia, a p-krezol és az indol koncentrációt, elősegíti a bifidobaktériumok és a laktobacillusok növekedését, és egyidejüleg csökkenti a Bacteriodaceae populációt (MussatTO \& MANCILHA, 2007; QIANG et al., 2009).

Az emberi szervezetre gyakorolt jótékony hatásaik miatt ezeket a vegyületeket funkcionális élelmiszerként tartják számon.

A legtöbb NDO-t a prebiotikumok közé sorolják, mivel szelektíven stimulálják az emberi szervezet számára hasznos baktériumok növekedését és/vagy metabolikus aktivitását. Fogyasztásuk kedvezően változtatja a vastagbél mikroflóra összetételét, javítja a szervezet egészségi állapotát (MussatTo \& MANCILHA, 2007). Egyes oligoszacharidok fiziológai tulajdonságait az 1. táblázat mutatja.

A fiziológiai hatás kapcsán érdemes kiemelni az anyatej-oligoszacharidok jelentőségét (HMO), ugyanis nagyon fontos szerepük van az újszülöttek védekezőképességének kialakításában. Eddig több mint 130 HMO típust azonosítottak, melyek felépítésében a laktóz, az $N$-acetil-laktózamin és/vagy a lakto- $N$-bióz részt vesz. A diszacharidok szializált és fukozilált formája is előfordul az anyatejben (KovÁCs et al., 2012). Az elmúlt évtizedben jelentősen növekedett az érdeklődés a biológiailag fontos oligoszacharidok szintézise és kereskedelmi forgalmazása iránt. Dékány Gyula kutatócsoportjával kidolgozott egy szabadalmaztatott eljárást HMO prekurzorok szintézisére. Az eljárással számos fontos HMO oligoszacharid „építőelem” (lakto- $N$-neotetraóz, lakto-N-tetraóz) állítható elő (DÉKÁNY et al., 2012). 


\section{1. táblázat: Oligoszacharidok fiziológiai hatásai}

\begin{tabular}{|c|c|c|}
\hline Oligoszacharid & Fiziológiai hatás & Referencia \\
\hline $\begin{array}{l}\text { Frukto- } \\
\text { oligoszacharidok }\end{array}$ & $\begin{array}{c}\text { vér koleszterin-, foszfolipid- és triglicerid szintjének } \\
\text { csökkentése } \\
\text { Mg és Ca felszívódásának elösegítése } \\
\text { prebiotikum }\end{array}$ & $\begin{array}{l}\text { SÁNCHEZ et al., } \\
2008\end{array}$ \\
\hline $\begin{array}{l}\text { Galakto- } \\
\text { oligoszacharidok, }\end{array}$ & $\begin{array}{c}\text { prebiotikum } \\
\text { vastagbélrák elleni védelem } \\
\text { székletürítés elősegítése } \\
\text { fekália ammóniatartalmának csökkentése }\end{array}$ & SAKO et al., 1999 \\
\hline Laktulóz & $\begin{array}{l}\text { bifidogén hatás } \\
\text { székrekedés enyhítése } \\
\text { májeredetủ agyvelöbántalom enyhítése }\end{array}$ & $\begin{array}{l}\text { CRITTENDEN \& } \\
\text { PLAYNE, } 1996\end{array}$ \\
\hline $\begin{array}{l}\text { Szója- } \\
\text { oligoszacharidok }\end{array}$ & $\begin{array}{l}\text { bifidogén hatás } \\
\text { anitoxidáns } \\
\text { vérnyomás csökkentő hatás }\end{array}$ & CHEN et al., 2010 \\
\hline Glükozil-szacharóz & nem kariogén & $\begin{array}{l}\text { CRITTENDEN \& } \\
\text { PLAYNE, } 1996\end{array}$ \\
\hline $\begin{array}{l}\text { Malto- } \\
\text { oligoszacharidok }\end{array}$ & $\begin{array}{c}\text { csökkenti a káros baktériumok (pl. a C. perfringes és az } \\
\text { Enterobacteriaceae családba tartozó fajok) számát illetve } \\
\text { aktivitását a szervezetben }\end{array}$ & $\begin{array}{l}\text { CRITTENDEN \& } \\
\text { PLAYNE, } 1996\end{array}$ \\
\hline $\begin{array}{c}\text { Mannan- } \\
\text { oligoszacharidok }\end{array}$ & $\begin{array}{c}\text { immunmoduláló szerep } \\
\text { patogének kolonizációjának gátlása a bélben }\end{array}$ & $\begin{array}{l}\text { DELGADO et al., } \\
\quad 2011\end{array}$ \\
\hline $\begin{array}{l}\text { Gentio- } \\
\text { oligoszacharidok }\end{array}$ & bifidogén hatás & $\begin{array}{l}\text { RYCROFT et al., } \\
\quad 2001\end{array}$ \\
\hline Laktoszacharóz & bifidogén hatás & $\begin{array}{l}\text { CRITTENDEN \& } \\
\text { PLAYNE, } 1996\end{array}$ \\
\hline $\begin{array}{c}\text { Xilo- } \\
\text { oligoszacharidok }\end{array}$ & prebiotikus hatás & $\begin{array}{l}\text { VÁZQUEZet al., } \\
2000\end{array}$ \\
\hline $\begin{array}{l}\text { Izomalto- } \\
\text { oligoszacharidok }\end{array}$ & bifidogén hatás & $\begin{array}{l}\text { KANEKO } \text { et al. } \\
1994\end{array}$ \\
\hline $\begin{array}{c}\text { Izomaltulo- } \\
\text { oligoszacharidok }\end{array}$ & bifidogén hatás & $\begin{array}{l}\text { NAKAJIMA \& } \\
\text { NISHIO, } 1993\end{array}$ \\
\hline $\begin{array}{l}\text { Kitozán- } \\
\text { oligoszacharidok }\end{array}$ & $\begin{array}{l}\text { anti-mikrobás hatás } \\
\text { tumorsejtek növekedésének gátlása } \\
\text { antioxidáns hatás } \\
\text { zsírok adszorpciójának gátlása a bélben } \\
\text { vér koleszterinszintjének csökkentése } \\
\text { immunstimuláló hatás } \\
\text { vérnyomáscsökkentö hatás } \\
\text { antikoaguláns aktivitás }\end{array}$ & $\begin{array}{l}\text { KIM \& RAJAPAKSE, } \\
2005\end{array}$ \\
\hline $\begin{array}{c}\text { Anyatej } \\
\text { oligoszacharidok }\end{array}$ & $\begin{array}{l}\text { bifidogén hatás, } \\
\text { antiadhezív, } \\
\text { antimikróbás hatás } \\
\text { glikom-módosító szerep } \\
\text { immunmoduláló hatás }\end{array}$ & BoDE, 2006 \\
\hline
\end{tabular}

\subsubsection{Fiziko-kémiai tulajdonságok}

$\mathrm{Az}$ oligoszacharidok vízben oldódó vegyületek. Édesítő képességük a szacharóznál kisebb (kb. $30-60 \%)$. Az édesítő hatásuk függ a kémiai szerkezettől, az oligoszacharid polimerizációs fokától és a termékben jelen levő mono- és diszacharidok mennyiségétől (CRITTENDEN \& Playne, 1996; Voragen, 1998). Delzenne (2003) szerint a lánchossz növelésével csökken az oligoszacharidok édesítő értéke. E tulajdonságuk alkalmas lehet olyan élelmiszerek gyártásánál, ahol a szacharóz felhasználása korlátozott a túlzott édesítő képessége miatt. Az oligoszacharidok 
használhatók „duzzasztó” anyagként mesterséges édesítőszerekkel együtt (például aszpartám, szukralóz), ahol az adalékanyagok utóízének elfedése a cél.

Az oldatuk viszkozitása függ a polimerizáltságuktól: minél nagyobb a molekulatömegük annál viszkózusabbak. Az egyes oligoszacharid típusok stabilitása is nagymértékben eltér, ez függ a felépítő cukoregységektől, a gyürüs és anomer szerkezettől valamint a kötés típusától. Általában a $\beta$-kötés erősebb az $\alpha$-kötésnél, és a hexózok erősebben kötöttek, mint a pentózok (MUSSATTO \& MANCILHA, 2007). Az élelmiszerekben lévő oligoszacharidok azonban pH 4 alatt és hőkezelés, vagy hosszantartó szobahőmérsékletü tárolás hatására hidrolizálódhatnak, így elveszítve táplálkozási és fizikai-kémiai tulajdonságaikat (MUSSATTO \& MANCILHA, 2007).

Az oligoszacharidok használhatók mélyhütött élelmiszerek fagyasztási hőmérsékletének megváltoztatására és a hőkezelt termékek Maillard reakció által okozott barnulásának csökkentésére. Fokozott nedvesség-visszatartási képességgel is rendelkeznek, amely megakadályozza az élelmiszerek túlzott kiszáradását. Kis vízaktivitást biztosítanak, ami alkalmas lehet mikrobiológiai szabályozásra. Emellett az oligoszacharidok a keményítő retrogradáció erős inhibitorai (PRAPUlla et al., 2000; MusSATTO \& MANCILHA, 2007). Kimutatták azt is, hogy az oligoszacharidok segítik a mikroorganizmusok stabilitásának megőrzését a fagyasztva szárítás és tárolás során (CACELA \& HINCHA, 2006; SCHWAB et al., 2007; TYMCZYSZYN et al., 2012).

\subsection{Oligoszacharidok előállítása fizikai és kémiai módszerekkel}

A funkcionális oligoszacharidok egyre növekvő alkalmazása (az élelmiszer-, gyógyszer-, kozmetika- és agrokémiai iparban) szükségessé teszi a nagyléptékü gyártási technológiák kidolgozását.

A kémiai és fizikai módszerek alkalmazása nem terjedt el. Ennek elsődleges oka a heterogén termékszerkezet, szintézis kisfokú specifitása és a bonyolult többlépéses gyártástechnológia.

A következő fizikai módszerek ismertek: mikrohullámú besugárzás, ultrahang és ionizáló sugárzás (BEKERS et al., 2005; AL-ASSAF et al., 2007; GIESE et al., 2010). A kémiai módszerrel történő előállításra is többféle technika ismert. A hőmérséklet és a $\mathrm{pH}$ drasztikus változtatásával előállíthatók oligoszacharidok (SCHMID et al., 2001; CARVALHEIRO et al., 2004; MIYAZAWA \& FUNAZUKURI, 2006). Az oligoszacharidok kémiai szintézisének legnagyobb problémája a régioszelektivitás biztosítása. Ennek az az oka, hogy a szénhidrátoknak számos hasonló reaktivitással rendelkező hidroxil csoportja van, így a régioszelektivitás elérése komplex és költséges feladat. További probléma a viszonylag alacsonya hozam, a keletkezett izomerek elválasztása és a nehezen megoldható a léptéknövelés. Az irodalomban található (MÜLLER et al., 1995), néhány kutatási célra felhasznált biológiai jelentőségü szénhidrát/oligoszacharid kémiai előállítási eljárás (pl.a-(1-2)-kötésű diszacharid származék, cukorszármazék tartalmú szénhidrát- 
mimetikum). Általános vélemény, hogy a kémiai oligoszacharid szintézis ma még nem alkalmazható ipari léptékben az élelmiszer- illetve gyógyszeriparban (MAITIN \& RASTALL, 2007; WEIJERS et al., 2008).

A kémiai módszerek fejlesztésének új irányzata a szilárd fázisú oligoszacharid szintézis. A szilárd fázisú oligoszacharid szintézis előnye, hogy a felépülő molekula erősen kötődik az oldhatatlan hordozóhoz, így a termék kinyerése és tisztítása könnyen megvalósítható (egyszerü mosással és szüréssel), a reakció a szintézis bármely szakaszában megszakítható, a konverzió nagy reagens koncentrációval növelhető, és a felesleg a reakció lejátszódása után egyszerüen eltávolítható (PLANTE et al., 2001).

A kémiai módszerek közé sorolható az alkáli izomerizáció is, mellyel laktózból laktulóz szintetizálható. A reakció során a laktóz, glükóz részét fruktózzá alakítják (AIDER \& HALLEUX, 2007).

\subsection{Oligoszacharidok kinyerése természetes forrásból}

Az élelmiszerek és az élelmiszeripari nyersanyagok (zöldségek, gyümölcsök, tej, méz) természetes formában is tartalmazhatnak fontos oligoszacharidokat (GIESE et al., 2010). Ezen oligoszacharidok kinyerésének legegyszerübb formája az extrakció. Az extrakciós eljárás alkalmazásáról főként a szója és inulin alapú oligoszacharidok kinyerésével kapcsolatban jelentek meg közlemények (KU et al., 1976; KAUR \& GUPTA, 2002; KiM et al., 2003; HU et al., 2007; WANG et al., 2010).

A szójabab és más hüvelyes növények nagy mennyiségü galaktozil-szacharóz oligoszacharidokat (pl. raffinózt, sztachiózt) tartalmaznak, melyek kinyerése megvalósítható extrakcióval (KU et al., 1976; KIM et al., 2003; WANG et al., 2010). Az eljárást már ipari méretben is alkalmazzák a Calpis Food Industry Co. cégnél (Japán).

A természetben előforduló szénhidrátok másik jelentős képviselői a fruktánok (pl. inulin), melyek számos növényben (főként a Liliaceae, Amaryllidaceae, Gramineae és Compositae család tagjaiban) megtalálhatók. Az inulin extrakciója (a szója-oligoszacharidokhoz hasonlóan) is már iparilag megvalósított, melyhez fóként két alapanyagot alkalmaznak, a cikória (Cichorium intybus) és a csicsóka (Helianthus tuberosus) gumóját (KAUR \& GUPTA, 2002; HU et al., 2007). A kidolgozott technológia hasonló a cukorrépa alapú szacharóz előállításához (NINESS, 1999) . $\mathrm{Az}$ ipari inulin extrakciónak nagy jelentősége van az inulin alapú frukto-oligoszacharidok előállításában.

A xilo-oligoszacharid előállítás szubsztrátumát a xilán poliszacharidot szintén extrakcióval nyerik ki, főként kukoricacsutkából (CRITTENDEN \& PLAYNE, 1996, YANG et al., 2005). 


\subsection{Oligoszacharidok előállítása enzimes technológiával}

Az utóbbi években az enzimes oligoszacharid előállítás vált elsődlegessé a technológiai fejlesztésekben. Az enzimes szintézissel kiküszöbölhetők a kémiai eljárások problémái, mint pl. az izomerek keletkezése, a reakciólépések nagy száma, a régio- és sztereospecifitás hiánya (MORACCI et al., 2001; MAITIN \& RASTALL, 2007). Biokatalizátorok alkalmazásával akár egylépésben megoldható egyes oligoszacharidok specifikus előállítása. Az oligoszacharid szintézist katalizáló enzimek előállítása elsősorban szubmerz fermentációval történik. A rögzített biokatalizátorok folyamatos eljárásokban alkalmazhatók és néhány rögzítési módszernél a hordozók újrahasznosíthatók, így gazdaságossá tehető felhasználásuk. A biokatalízisben elsősorban glikozidázokat és glikoziltranszferázokat alkalmaznak.

\subsubsection{Glikozidázok (GH)}

A glikozidázok (glikozil hidrolázok, EC 3.2.1.X) széles körben előforduló hidrolázok, amelyek a glikozidos kötések hasításáért felelősek. Már többezer glikozidáz enzim ismert a természetben, amelyek segítségével gyakorlatilag minden glikán kötés lebontható. A biotechnológiai fejlesztéseknek köszönhetően ma már sok glikozidáz készítmény kapható kereskedelmi forgalomban. A GH-ok a glikobiológia számos területén alkalmazhatók. Segítségükkel információt szerezhetünk glikozidos kötésekről és/vagy egyszerüsíthetünk glikozidos szerkezeteket. Emellett figyelemre méltó a glikohidrolázok élelmiszeripari jelentősége is, különösen a tejipari folyamatokban való részvételük.

A glikozidázok szubsztrátum specifikussága igen változó. Néhány glikozidáz ipari alkalmazásánál előnyös lehet a kis szubsztrátum specifikusság, amely azt jelenti, hogy több fajta szubsztrátumot is termékké lehet alakítani. Emellett egyes glikozidázok nagy szubsztrátum specifikussággal rendelkeznek, ami hasznos lehet az egyes gyógyászatilag vagy iparilag fontos gliko-protein vagy más glikostruktúra szelektív módosításában, vagy komplex szerkezetek vizsgálatában (FILICE \& MARCIELLO, 2013). Mind az exo-, mind az endo-glikozidázok fontos biológiai folyamatok résztvevői. In vivo ezek az enzimek hasítják el a glikozidos kötéseket, in vitro azonban a reakciókörülmények és az enzimforrás gondos megválasztásával glikozidok szintézisére is alkalmazhatók (PALCIC, 1999; FILICE \& MARCIELlO, 2013). Szintézis céljára föként exo-glikozidázokat használnak.

A GH-ok több mint 100 különböző enzimcsaládot foglalnak magukban, melyek annak ellenére, hogy nagy diverzitást mutatnak térbeli szerkezetüket tekintve (pl. másodlagos fehérje szerkezet, aktív centrum) hasonló jellegzetességeket mutatnak. (HANCOCK et al., 2006; FILICE \& MARCIELLO, 2013). A glikohidroláz enzimek aktív centrumában, eredetüktől függetlenül, két 
eltérő disszociált állapotú karboxil oldallánc található, amelyek általánosan 7-11 Å (angström; $1 \AA$ = $0,1 \mathrm{~nm}$ ) távolságra helyezkednek el egymástól.

A glikozidázok megtartó és invertáló tulajdonságuk alapján is megkülönböztethetők, attól függően, hogy a donor molekula anomer kötésének sztereokémiája változatlan marad $(\alpha \rightarrow \alpha, \beta \rightarrow \beta)$ vagy invertálódik $(\alpha \rightarrow \beta)$. A glikozidázok által katalizált hidrolízis háromféle mechanizmus szerint játszódhat le. Mindháromra jellemző, hogy víz belépésével történő sav/bázis reakció katalizálta hasítás megy végbe, melyben a karboxil oldalláncok kulcsfontosságú szerepet játszanak (FILICE \& MARCIELLO, 2013).

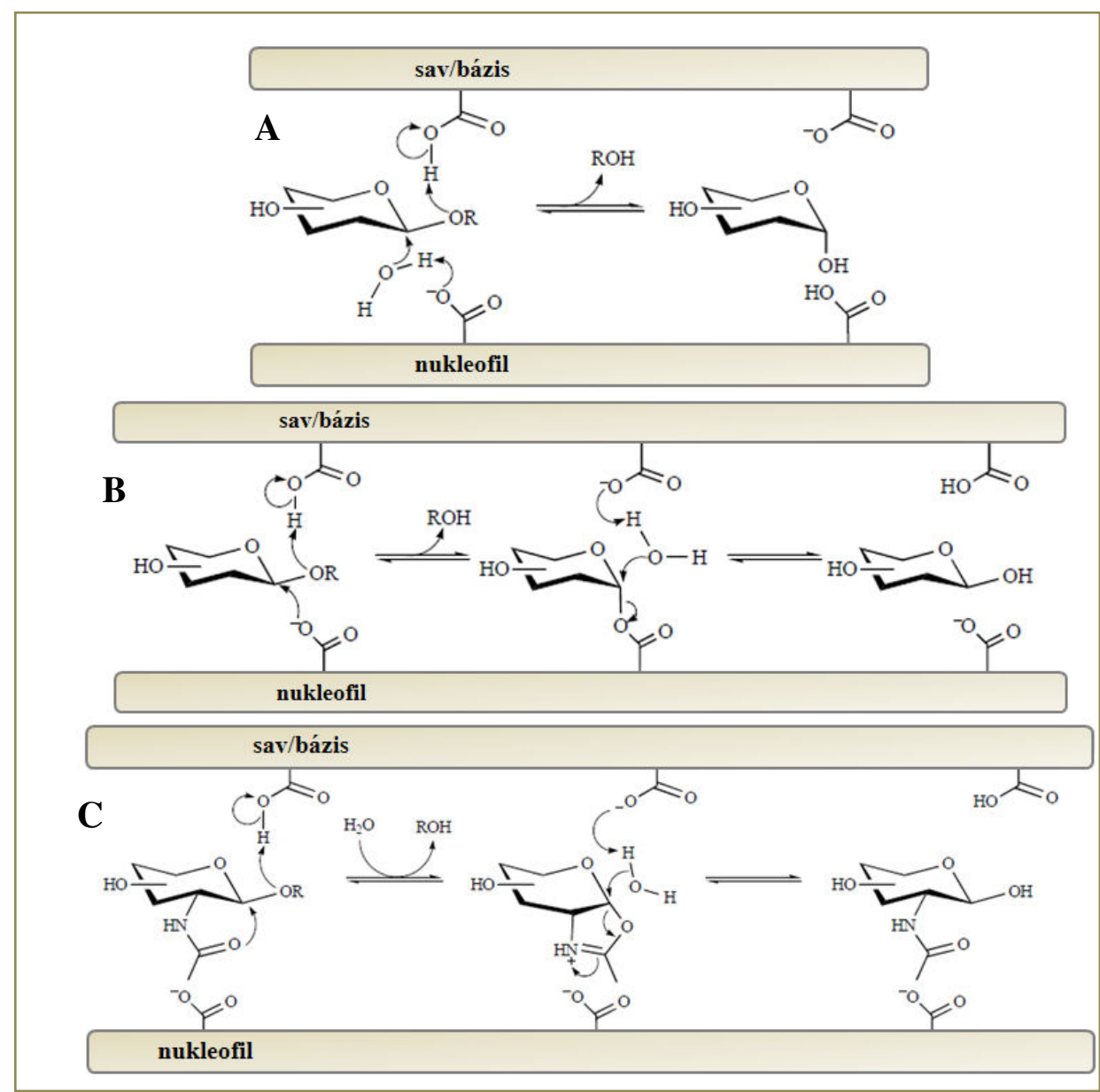

\section{4. ábra: A. Invertáló hidroláz mechanizmusa \\ B. Megtartó hidroláz mechanizmusa \\ C. $\beta$-N-acetil-hexózaminidáz mechanizmusa (FILICE \& MARCIELlo, 2013)}

Az invertáló mechanizmus egy közvetlen kicserélődési folyamat, ahol a glikozidos kötés hasítása közvetlenül egy aktivált vízmolekula által történik, amely az anomer szénatom inverziójához vezet (4.A. ábra).

A konformációt megtartó mechanizmust elöször KOSHLAND (1953) írta le. Ebben az esetben az enzimek egy kétlépéses, dupla kicserélődésen alapuló mechanizmussal katalizálnak, amely az anomer szénatom sztereokémiai szerkezetének a megtartásához vezet (4.B. ábra). 
A glikozidázok egyes tagjai egy úgynevezett szubsztrátum-támogatott („,substrate-assisted”) mechanizmus utat katalizálnak (4.C. ábra). E reakció során a szubsztrátum funkciós csoportja részt vesz a katalízisben. A folyamatot a donor molekula sztereokémiai állapotának megtartása jellemzi (DALL'ACQUA \& CARTER, 2000; FILICE \& MARCIELlO, 2013).

\subsubsection{Szintézis}

Az elmúlt években az oligoszacharidok enzimes előállítása vált számos kutató által választott módszerré (CANEDo et al., 1999; ChITRADON et al., 2000; HomAnn \& SEIBEL, 2009). Az oligoszacharidok e módon történő szintézise során ugyanis kiküszöbölhetők a kémiai módszernél fellépő problémák, mint pl. izomerek keletkezése, reakciólépések nagy száma, régio- és sztereospecifitás hiánya. További előnye, hogy változatos reakciókörülmények között alkalmazható (MORACCI et al., 2001; MAITIN \& RASTALL, 2007). Az enzimes technológiával akár egylépéses reakció segítségével megoldható az oligoszacharidok előállítása. A glikozidázok könnyen elérhetők különböző forrásokból (mikroorganizmusok, növényi és állati sejtek), ellenállóak különböző szerves oldószerekkel szemben, a reakcióhoz nem igényelnek kofaktorokat (PALCIC et al., 1999). Elönyük a glikoziltranszferázokkal szemben, hogy nem szükséges drága nukleotid aktivált donor szubsztrátum a reakcióhoz, valamint kevésbé drágák (ICHIKAWA et al., 1992). Hátrányuk azonban, hogy a szintetizált termék az enzim szubsztrátumává válhat és hidrolizálhatja azt. E problémára megoldást jelenthet a termékhidrolízis minimalizálása, amely a reakció körülmények ( $\mathrm{pH}$, donor molekula mennyiségének, kevert oldószer jelenlétének) optimálásával érhető el (AKAIKE et al., 2004; FiliCE \& MARCIELLO, 2013). Alkalmazásukat háttérbe szoríthatja az alacsony termékhozam, valamint az, hogy az általuk katalizált transzglikozilációs reakciók során régio-izomerek keletkezhetnek (az akceptor molekula szerkezetétől függően), ami problémát okozhat a termék tisztításánál (PALCIC, 1999; MoRACCI et al., 2001). A glikozidázok alkalmazását korlátozó tényezők elkerülésére a mutáns glikozidázok létrehozása, illetve a szubsztrátum mérnökség jelenthet megoldást. Már számos kutató foglalkozott mutáns glikozidázok, más néven glikoszintázok előállításával (OKUYAMA et al., 2002; PERUGINO et al., 2004).

Az oligoszacharidok szintézisére alkalmas legtöbb glikozidáz enzim exo-glikozidáz típusú, amelyek monoszacharid egység átvitelét katalizálják egy akceptor szubsztrátum nem-redukáló terminális monoszacharid egységére. A glikozidázok esetében a glikozil donor molekula lehet monoszacharid, oligoszacharid vagy aktivált glikozid. Mind az invertáló, mind a megtartó GH-ok képesek szénhidrát szintézisre, azonban különböző mechanizmussal. Az invertáló enzimek egy kondenzációs reakciót katalizálnak (egyensúly-kontrollált szintézis/reverz hidrolízis), a megtartó enzimek emellett képesek transzglikozilációs reakciót is katalizálni 
(kinetikailag kontrollált szintézis/transzglikoziláció) nagy akceptor koncentráció (ami nem víz) jelenlétében (PALCIC, 1999; MAITIN \& RASTALL, 2007).

Magyar kutatók, FEKETE és KISS (2012) elsőként cáfolták ezen megállapítást, ugyanis olyan invertáló mechanizmussal rendelkező Thermobifida fusca eredetű rekombináns $\beta$-D-xilozidázt állítottak elö, amely képes xilobióz és p-nitrofenil- $\beta$-D-xilopiranozid szubsztrátumokon transzxilozilációt katalizálni.

\section{Reverz hidrolízis}

A glikozidázok képesek a glikozidos kötések hasítására és létrehozására is. A reverz hidrolízis egy termodinamikailag kontrollált reakció, amely a glikozid hidrolízis megfordítását jelenti. A reverz hidrolízis sémája az 5. ábrán látható, ahol A és B glikozil egységeknek felelnek meg.

$$
\mathrm{A}-\mathrm{H}+\mathrm{B}-\mathrm{OH} \stackrel{\text { Glikozidáz }}{\rightleftharpoons} \mathrm{A}-\mathrm{B}+\mathrm{H}_{2} \mathrm{O}
$$

\section{5. ábra: Reverz hidrolízis reakció (MONSAN \& PAUL, 1995)}

Abból a célból, hogy a reakció egyensúlyát a termékképzés irányába fordítsák, különböző módszereket alkalmaznak. Az egyik legelterjedtebb módszer a hidrolízis termék (pl. monoszacharidok) koncentrációjának (70 - 80\%-ra) növelése (JOHANSSON et al., 1989; AJISAKA et al.,1995) és ezzel a vízaktivitás csökkentése. A víztartalom csökkentése szerves oldószerek alkalmazásával is megoldható (CROUT \& VIC, 1998; BALOGH et al., 2004). Hőmérséklet emelésével (50 - $60{ }^{\circ} \mathrm{C}$-ra) gyorsítható a reakció lejátszódása (AJISAKA et al.,1995; MAITIN \& RASTALL, 2007). A módszer előnye az egyszerüség, mellyel mind homo-, mind heterooligoaszacharidok szintézise lehetséges (RASTALL et al., 1992).

Reverz reakcióval már nagy hatékonysággal állítottak elő mannózból manno-oligoszacharidokat, a-mannozidáz enzim (EC 3.2.1.24) felhasználásával (DELZENNE \& RoBERFROID, 1994). A manno-oligoszacharidok előállítás jelentősége, hogy számos glikoprotein építőkövei és bizonyítottan anti-adheziós tulajdonsággal rendelkeznek (MAITIN \& RASTALL, 2007). A mannózból történő oligoszacharid szintézis egyik előnye, hogy a szubsztrátum jó oldhatóságának köszönhetően a nagy koncentráció alkalmazása nem okoz technológiai problémát. Eddigi tanulmányokban reverz hidrolízisre kardbab (Canavalia ensiformis) (JOHANSSON et al., 1989; RASTALl et al., 1992), mandula, tengeri kagyló (SINGH et al., 2000), Aspergillus phoenicus (Athanasopoulos et al., 2004), Aspergillus niger (SINGH et al., 2000), Penicillium citrinum (MAITIN \& RASTALL, 2004) eredetü $\alpha$-mannozidáz enzimeket vizsgáltak. A különböző eredetü $\alpha$-mannozidázokkal eltérő szerkezetü termékeket állítottak elö. Az $\alpha$ - és $\beta$-glükozidos kötéseket 
hasító enzimek valamint az $\alpha$-galaktozidáz (EC 3.2.1.22) is katalizálhatnak reverz hidrolízis reakciót, di- és oligoszacharidokat termelve (2. táblázat).

2. táblázat: Különböző eredetű glikozidázok és reverz hidrolízis termékeik

\begin{tabular}{|c|c|c|c|c|}
\hline Enzim & Eredet & Szubsztrátum & Termék & Referencia \\
\hline$\alpha$-mannozidáz & $\begin{array}{c}\text { közönséges } \\
\text { csészecsiga (Patella } \\
\text { vulgata) }\end{array}$ & mannóz & $\begin{array}{c}\text { mannobióz } \alpha(1-2) \text { és } \\
\alpha(1-3) \text { kötéssel }\end{array}$ & SINGH et al., 2000 \\
\hline$\alpha$-mannozidáz & $\begin{array}{l}\text { mandula liszt } \\
\text { (Prunus } \\
\text { amygdalus), }\end{array}$ & mannóz & $\begin{array}{l}\text { mannobióz } \alpha(1-6), \alpha(1-2) \\
\text { és } \alpha(1-3) \text { kötéssel }\end{array}$ & SINGH et al., 2000 \\
\hline a-mannozidáz & Aspergillus niger & mannóz & mannobióz $\alpha(1-6)$ & SINGH et al., 2000 \\
\hline a-mannzidáz & $\begin{array}{l}\text { Aspergillus } \\
\text { niger }\end{array}$ & mannóz & $\begin{array}{l}\text { mannobiózok } \alpha(1-2), \\
\alpha(1-3), \alpha(1-6) \text { kötéssel } \\
\text { mannotriózok } \alpha(1-2) \text { és } \\
\alpha(1-2)-\alpha(1-6) \\
\text { kötésekkel }\end{array}$ & $\begin{array}{l}\text { AJISAKA et al., } \\
1995\end{array}$ \\
\hline $\begin{array}{c}\text { 1,6- } \alpha- \\
\text { mannozidáz }\end{array}$ & $\begin{array}{l}\text { Aspergillus } \\
\text { phoenicis }\end{array}$ & mannóz & 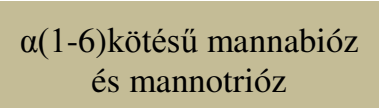 & $\begin{array}{l}\text { ATHANASOPOULOS } \\
\text { et al., } 2004\end{array}$ \\
\hline $\begin{array}{c}\text { 1,2- } \alpha- \\
\text { mannozidáz }\end{array}$ & $\begin{array}{l}\text { Aspergillus } \\
\text { phoenicis }\end{array}$ & mannóz & $\begin{array}{l}\alpha(1-2) \text { kötésü mannobióz } \\
\text { és mannotrióz }\end{array}$ & $\begin{array}{l}\text { SUWASONO \& } \\
\text { RASTALL, } 1996\end{array}$ \\
\hline$\beta$-glükozidáz & $\begin{array}{c}\text { Dalbergia } \\
\text { cochinchinensis }\end{array}$ & glükóz & glükobióz, glükotrióz & $\begin{array}{c}\text { SRISOMSAP et al., } \\
1999\end{array}$ \\
\hline$\beta$-glükozidáz & $\begin{array}{c}\text { Dalbergia } \\
\text { cochinchinensis }\end{array}$ & $\begin{array}{l}\text { glükóz } \\
\text { +fukóz }\end{array}$ & $\begin{array}{l}\alpha(1-6) \text { kötésű } \\
\text { fukozil-glükóz }\end{array}$ & $\begin{array}{l}\text { SRISOMSAP et al., } \\
1999\end{array}$ \\
\hline$\beta$-glükozidáz & $\begin{array}{c}\text { Trichoderma reesei } \\
\text { (E.coli } \\
\text { baktériumban } \\
\text { expresszálva) }\end{array}$ & glükóz & szoforóz, cellobióz & $\begin{array}{l}\text { SALOHEIMO et al., } \\
1999\end{array}$ \\
\hline -glükozidáz & $\begin{array}{c}\text { Bacillus } \\
\text { stearothermophilus }\end{array}$ & glükóz & $\begin{array}{l}\text { izomaltóz, nigeróz, } \\
\text { maltóz, kojibióz }\end{array}$ & $\begin{array}{c}\text { MALÁ \& KRÁLOVÁ, } \\
2000\end{array}$ \\
\hline glükoamiláz & Aspergillus niger & $\begin{array}{c}\text { glükóz } \\
+ \text { akceptorok }\end{array}$ & heterooligoszacharidok & $\begin{array}{c}\text { RASTALL et al., } \\
1991\end{array}$ \\
\hline $\alpha$-amiláz & $\begin{array}{l}\text { Aspergillus } \\
\text { licheniformis }\end{array}$ & $\begin{array}{l}\text { keményítő } \\
\text { +akceptorok }\end{array}$ & heterooligoszacharidok & $\begin{array}{l}\text { CHITRADON et al., } \\
2000\end{array}$ \\
\hline $\begin{array}{l}\text { cellobiohidroláz } \\
\text { endoglükanáz }\end{array}$ & Trichoderma reesei & glükóz & glüko-oligoszacharidok & $\begin{array}{c}\text { GAMA \& MOTA, } \\
1998\end{array}$ \\
\hline $\alpha$-galaktozidáz & $\begin{array}{c}\text { Candida } \\
\text { guilliermondii }\end{array}$ & galaktóz & $\begin{array}{c}\alpha(1-6), \alpha(1-3), \alpha(1-2) \\
\text { kötésü galaktobióz }\end{array}$ & $\begin{array}{l}\text { HASHIMOTO et al., } \\
2001\end{array}$ \\
\hline
\end{tabular}

A reverz hidrolízist kiterjedten alkalmazzák $O$-glikozidok előállítására is (VULFSON et al., 1990; Drouet et al., 1994; Vic \& CROUT, 1995; KosÁry et al., 1998; KobAYASHi et al., 2000; BALOGH et al., 2004). Az egyszerü cukrok (elsősorban glükóz) alifás alkoholokkal képzett $O$-glikozidjai a nem ionos, felületaktív anyagok egyik fontos csoportját képezik, antimikrobás tulajdonságokkal rendelkeznek, valamint biológiailag lebonthatók (PANINTRARUX et al., 1995). 


\section{Transzglikoziláció}

A katalízis olyan transzfer reakció, amelynél a végső akceptor a víz. Ezekben a reakciókban gyakran jelenik meg egy kovalens kötésű enzim-szubsztrátum intermedier. Ez az intermedier teszi lehetővé, hogy a glikozidáz enzimeket transzglikoziláció katalízisére használják (MONSAN \& PAUL, 1995). A transzfer reakcióban az enzim egy glikozid származékról glikozil egységet visz át egy hidroxil csoportot tartalmazó akceptor molekulára. A glikozidázok által katalizált transzglikozilációt a 6. ábra mutatja, ahol A-B a glikozid donor, E a glikozidáz és $\mathrm{C}$ az akceptor molekula.

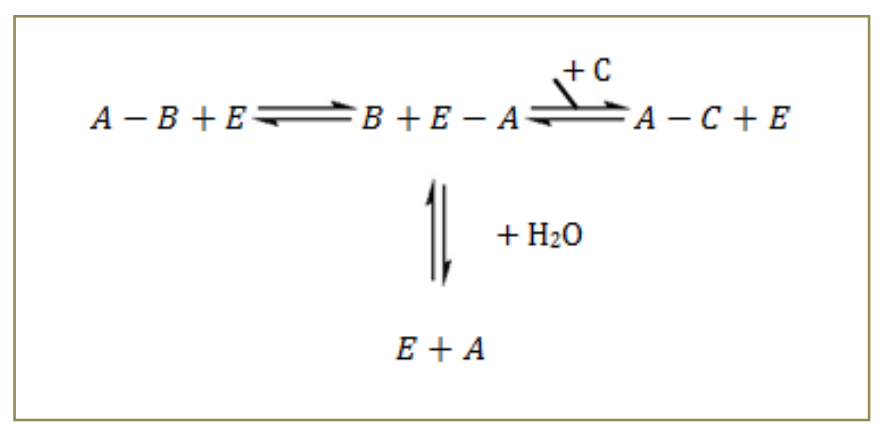

6. ábra: Transzglikozilációs reakció (MONSAN \& PAUL, 1995)

A kinetikailag kontrollált reakcióban a keletkezett A-C termék későbbi lehetséges szubsztrátuma a glikozidáz enzimnek. A végső hozam fokozható a donor-akceptor koncentráció növelésével, a vízaktivitás csökkentésével, a végső termék reakcióközegből történő folyamatos eltávolításával illetve a megfelelő szerkezetü akceptor molekula kiválasztásával, amellyel befolyásolható a keletkezett termék glikozidos kötésének a típusa is.

3. táblázat: Glikozidázok és transzglikozilációs termékeik

\begin{tabular}{|c|c|c|c|c|}
\hline Enzim & Donor & Akceptor & $\begin{array}{c}\text { Termék } \\
\text { Szerkezet }\end{array}$ & Referencia \\
\hline$\beta$-galaktozidáz & laktóz & laktóz & $\begin{array}{c}\text { galakto-oligoszacharidok } \\
\alpha-D-G l u-(1-4)-[\beta-D-G a l-(1-6)-] n\end{array}$ & TORRES et al., 2010 \\
\hline$\beta$-fruktofuranozidáz & szacharóz & szacharóz & $\begin{array}{c}\text { frukto-oligoszacharidok } \\
\alpha-D-G l u-(1-2)-[\beta-D-F r u-(1-2)-] n\end{array}$ & $\begin{array}{l}\text { CRITTENDEN \& } \\
\text { PLAYNE, } 1996\end{array}$ \\
\hline$\beta$-fruktofuranozidáz & szacharóz & laktóz & $\begin{array}{c}\text { lakto-szacharóz } \\
\beta \text {-D-Gal-(1-4)- } \alpha \text {-D-Glu-(1-2)- } \beta \text {-D- } \\
\text { Fru }\end{array}$ & $\begin{array}{c}\text { MUSSATTO \& } \\
\text { MANCILHA, } 2007\end{array}$ \\
\hline $\alpha$-glükozidáz & maltóz & glükóz & $\begin{array}{l}\text { izomalto-oligoszacharidok } \\
{[\alpha-D-G l u-(1-6)] n}\end{array}$ & $\begin{array}{l}\text { CRITTENDEN \& } \\
\text { PLAYNE, } 1996\end{array}$ \\
\hline$\beta$ - glükozidáz & glükóz & glükóz & $\begin{array}{c}\text { gentio-oligoszacharidok } \\
{[\beta \text {-D-Glu- }(1-6)] \mathrm{n}}\end{array}$ & $\begin{array}{c}\text { MUSSATTO \& } \\
\text { MANCILHA, } 2007\end{array}$ \\
\hline
\end{tabular}

A legtöbb esetben a glikohidrolázok transzglikozilációs reakcióját alkalmazzák oligoszacharidok előállításra, mivel ennek sebessége és hozama nagyobb a reverz hidrolízishez képest. Számos 
példa van a glikozidázok transzglikozilációs képességének alkalmazására az élelmiszeriparban is (3. táblázat).

A GH-ok közül a $\boldsymbol{\beta}$-galaktozidázok (EC 3.2.1.23) a legjelentősebbek az élelmiszeriparban, mivel alkalmazásukkal lebontható a tej laktóz tartalma illetve értékes galakto-oligoszacharidok szintetizáhatók. Ezen oligoszacharidokat a laktózból állítják elő a $\beta$-galaktozidáz (laktáz) enzim által katalizált transzgalaktozilációs reakcióval (NGUYEN et al., 2015). Szubsztrátumként általában tejsavóból kinyert nagy koncentrációjú laktózt alkalmaznak. A reakció fő termékei triszacharidok (4- vagy 6-galaktozil-laktóz), de szintetizálódhat négyes vagy annál nagyobb polimerizáltságú oligoszacharid is (MUSATTO \& MANCILHA, 2007; GosLING et al., 2010; TORRES et al., 2010). A $\beta$-galaktozidáz enzimek alkalmazásával nem csak oligoszacharidok szintetizálhatók. CARDEllE-COBAS és munkatársai (2008) kimutatták, hogy a Pectinex ultra SP-L kereskedelmi enzimkészítményben lévő (Aspergillus aculeatus eredetű) $\beta$-galaktozidáz enzim galakto-oligoszacharidok mellett képes glicerin jelenlétében galaktozil- és digalaktozilglicerolt is szintetizálni. Szintén bizonyították, hogy ez az enzim alkalmas laktulóz alapú oligoszacharidok előállítására is (CARDELLE-COBAS et al., 2008). Később ezt a képességet a Kluyveromyces lactis eredetü $\beta$-galaktozidázzal is igazolták (CARDELLE-COBAS et al., 2011).

$\mathrm{Az}$ oligoszacharidok másik jelentős csoportja a frukto-oligoszacharidok, amelyek előállítása szacharóz szubsztrátum felhasználásával történik (NGUYEN et al., 1999). A transzfruktozilációs reakció elve, hogy a $\boldsymbol{\beta}$-fruktofuranozidáz (EC 3.2.1.26) képes a szacharóz molekuláról egy fruktóz egységet átvinni egy másik szacharóz molekulára. Ennek eredményeként különböző polimerizáltsági fokú frukto-oligoszacharidok keletkezhetnek (1-kesztóz, 1-nisztóz, fruktozilnisztóz). Az irodalomban számos példa található $\beta$-fruktofuranozidáz enzim izolálására és oligoszacharid szintézisre (WIN et al., 2004; ÁlVARO-BENITO et al., 2007; YANG et al., 2008; YosHIKAWA et al., 2008). A frukto-oligoszacharidok szintézise során melléktermékként fruktóz, glükóz keletkezik és szacharóz is visszamarad a reakcióelegyben. A nem kívánatos szénhidrátokat kromatográfiás eljárással távolíthatók el a termékből (CRITTENDEN \& PLAYNE, 1996; KUHN et al., 2012).

A $\beta$-fruktofuranozidáz enzim másik felhasználási módja is ismert, a lakto-szacharóz szintézis. Ez esetben viszont a szacharóz fruktóz alkotója egy laktóz molekulához kapcsolódik. A triszacharid bifidogén hatása bizonyított (CRITTENDEN \& Playne, 1996, Musatto \& MANCilHA, 2007). Emellett jelentek meg tanulmányok arról, hogy $\beta$-fruktofuranozidáz enzimmel lehetőség van fruktozil-szteviozid (SUZUKI et al., 2002), tio-fruktofuranozid (NAKANO et al., 2000) és neofrukto-oligoszacharid (a glükóz és a fruktóz molekula között $\beta(2-6)$-kötés) előállítására is (GIMENO-PEREZ et al., 2014). 
A transzglikozilációs reakciót katalizáló enzimek közé sorolható az $\boldsymbol{\alpha}$-glükozidáz (EC 3.2.1.20) is, melyet az izomalto-oligoszacharidok előállítására alkalmaznak. E szénhidrátok előállítása kétlépéses enzimkatalízissel történik. Első lépésben a keményítő folyósítása történik $\alpha$-amilázzal, majd a második lépésben a folyósított keményítő kezelése $\beta$-amiláz és $\alpha$-glükozidáz enzim felhasználásával. A második fázisban a folyósított keményítőből képződött maltóz, az a-glükozidáz által katalizált transzglükoziláció révén átalakul izomalto-oligoszachariddá. Az izomalto-oligoszacharidok $\alpha(1-6)$ kötésű glükóz egységekből állnak, azonban a reakció során keletkezhetnek olyan oligoszacharidok is, amelyek $\alpha(1-4)$ kötést is tartalmaznak (pl. panóz). Az izomalto-oligoszacharidok bifidogének és prebiotikus élelmiszer-összetevőként alkalmazhatók (Mussatto \& MAnCilha, 2007; CRITTENDEN \& Playne, 2009). Az $\alpha$-glükozidázok transzferáz aktivitásának tanulmányozásával számos kutató foglalkozik. KURIMOTO és munkatársai (1997) biszubsztrátum rendszerben vizsgálták oligoszacharidok előállítását Aspergillus niger eredetü $\alpha$-glükozidázzal. Donor molekulaként maltotetraózt, akceptorként trehalózt alkalmaztak. Az általuk szintetizált termékek a következők voltak: $\alpha$-izomaltozil-glükozid, $\alpha$-izomaltotriozilglükozid és $\alpha$-izomaltozid. HUNG és munkatársai (2005) mélytengeri Geobacillus eredetü a-glükozidázzal kimutatták, hogy számos szénhidrátot képes szubsztrátumként felismerni (szacharóz, mint donor és akceptor, szorbóz mint akceptor), emellett akceptorai nem csak cukormolekulák lehetnek (pl. kloramfenikol, szalicin, kortizon). ANDREOTTI és munkatársai (2006) Aplysia fasciata eredetü $\alpha$-glükozidáz tanulmányozása során azt tapasztalták, hogy az enzim képes volt a szacharóz, a cellobióz, és a piridoxin glükozilálására, valamint pNP-di- és triszacharidok szintézisére.

A $\boldsymbol{\beta}$-glükozidáz (EC 3.2.1.21) enzim felhasználásával is lehetséges oligoszacharidok szintézise. A keményítő hidrolízisét követően a $\beta$-glükozidáz transzfer aktivitásával gentiooligoszacharidok képezhetők. A módszert már az iparban is alkalmazzák (MUSSATTO \& MANCILHA, 2007). Az enzim transzglikozilációs képessége felhasználható alkil-glükozidok előállítására is (SVASTI et al., 2003). Emellett kimutatták, hogy létezik olyan (Termotoga neapolitana eredetü) $\beta$-glükozidáz enzim, amely képes transzglükozil reakciót katalizálni cellobióz és laktóz szubsztrátumokon (PARK et al., 2005).

\section{Szintetikus szubsztrátumok alkalmazása}

A transzglikozilációs oligoszacharid szintézis egyik újabban vizsgált területe a különböző cukorszármazékok alkalmazhatóságának kutatása. Számos közlemény jelent meg az enzimológiában széles körben használt nitrofenil-cukrok alkalmazásáról (AJISAKA et al., 1994; MURATA et al., 1997). 
A nitrofenil-cukrok mellett két új típusú szintetikus szubsztrátumot, a glikozil-fluoridot és a cukor-oxazolint is vizsgálták. Ezeket a cukor származékokat a glikozilhidrolázok hatékonyan befogadják szubsztrátumként és használatuk számos előnnyel rendelkezik (FILICE \& MARCIELLO, 2013). A glikozil-fluorid esetén az enzimes reakció sorána fluor atom hidroxil csoportként viselkedik, így meg tud kötődni az enzim aktív centrumában. Emellett a glikozil-fluorid molekula stabilis szerkezete ellenére, az enzim vizes közegben is könnyen képes a glikozilfluorid C-F kötését hasítani (WILLIAMS \& WITHERS, 2000).

A cukor-oxazolin szintén hatékony glikozil-donor, mivel a megtartó reakció mechanizmusban az oxazol utánozza a szubsztrátum támogatott (ES) átmeneti állapotot. Gyakorlatilag kevesebb donor molekula jelenlétével növelhető a biokonverzió hatékonysága. Ezzel az egyszerü technikával már számos glikozil szerkezetet szintetizáltak (FILICE \& MARCIELLO, 2013).

Legújabban a glikozil-azidok is nagy figyelmet kaptak az oligoszacharidok szintézisében. Ez annak köszönhető, hogy könnyebben, nagyobb hozammal állíthatók elő mint a nitrofenilszármazékok. Emellett oldhatóságuk is nagyobb. E szénhidrát donort alkalmazva, a C-N kötés bontása oligoszacharid terméket eredményez. A reakcióban rész vesznek a $\beta$-N-acetilhexózaminidázok, $\alpha$-mannozidázok, $\beta$-glükozidázok és $\beta$-galaktozidázok (FIALOVÁ et al., 2005; BOJAROVÁ et al., 2007;COBUCCI-PONZANO et al., 2009).

\section{Mutáns glikozidázok (glikoszintázok) alkalmazása}

Kétségtelenül a glikozidázok alkalmazásának egyik legnagyobb hátránya, hogy az oligoszacharid szintézis során keletkező termék az enzim szubsztrátumává válik, így csak mérsékelten jó hozam érhető el. A hozamnövelés mutációs technikával megoldható, mellyel az enzimek egy új csoportja állítható elő, a glikoszintázok (GS-ok) (MACKENZIE et al., 1998). A glikoszintázok képesek nagy hozamú glikán szintézisre, az előállított termék hidrolízise nélkül. A mutáció során a katalitikus hely nukleofil részét egy nem-nukleofil részre (pl. alanin) cserélik, melynek köszönhetően az enzim nem képes hidrolízis reakciót katalizálni viszont alkalmas glikozidos kötések kialakítására (FILICE \& MARCIELLO, 2013).

A glikoszintázok hatásmechanizmusát tekintve is megkülönböztetünk endo- és exoglikoszintázokat illetve megtartó és invertáló glikoszintázokat (MACKENZIE et al., 1998; HONDA \& KITAOKA, 2006; UMEKAWA et al., 2010). Alkalmazásukkal oligoszacharidok, poliszacharidok és glikokonjugátumok széleskörü előállítása lehetséges. A glikoszintáz előállításról és alkalmazásról elsőként WITHER és kutatócsoportja (WANG et al., 1994, MACKENZIE et al., 1998) számolt be (Agrobacterium sp. $\beta$-glükozidáz mutáns). Kísérletükben az enzim katalitikus helyének nukleofil részét (Glu358) alaninra cserélték. Az így előállított glikoszintáz (Glu358Ala mutáns) elvesztette hidrolitikus aktivitását és képessé vált $\beta$-D-glikozil oligoszacharid 
származékok előállítására, $\alpha$-glikozil-fluorid ( $\alpha$-galaktozil-fluorid) és 4-nitrofenil-glikozid szubsztrátumok alkalmazásával. Ez 80\% feletti hozamot eredményezett. MAYER és munkatársai (2000) hasonló módon a nukleofil rész (Glu358) szerinre való cseréjével 24-szeresre növelték a szintézis hatékonyságát. Az mutáns enzim (Glu358Ser mutáns) felhasználásával a 4-nitrofenilacetil-glükózamint glikozilálták. A szintetizált 4-nitrofenil- $\beta$-N-acetillaktózamin értékes prekurzora a sejtfelszíni antigéneknek.

A $\beta$-D-mannozid kötések glikoszintázzal történő létrehozását szintén nagy érdeklődés övezi. Ez annak köszönhetö, hogy e kötéstípus számos biológiai rendszerben megtalálható (különösen a glikoproteinekben), és kémiai módszerrel az egyik legnehezebben elöállítható glikozidos kötés (GÜNTHER \& KunZ, 1992; Filice \& MARCIELlO, 2013). NASHIRU és munkatársai (2001) sikeresen állítottak elő mannoszintáz enzimet egy megtartó $\beta$-mannozidázt kódoló gén mutációjával. Az enzim felhasználásával $\alpha$-D-mannozil-fluoridból szintetizáltak $\beta(1-3)$ - és $\beta(1-4)$-mannozidokat nagy hozammal (70\%). JAHN és munkatársai (2003) ugyanazon szubsztrátum alkalmazásával $\beta(1-4)$ kötésủ manno-oligoszacharidok előállítását valósították meg a Cellvibrio japonicus eredetű mannánszintáz enzimmel. Ezen kívül számos új glikoszintázt állítottak elő, amellyel $\beta$-glikozidos kötések szintézise kivitelezhető.

Az a-glükozidáz mutánsok előállításával kapcsolatban is folynak kutatások. Elsőként OKUYAMA és munkatársai (2002) írták le az a-glükoszintáz reakciót. Schizosaccharomyces pombe a-glükozidáz enzimének Asp481 nukleofil csoportját cserélték glicinre. A mutáns enzim (D481G) felhasználásával $\alpha$-glükozidos kötéseket hoztak létre, azaz $\alpha$-konfigurációjú oligoszacharid származékok előállítását végezték $\beta$-glükozil-fluorid és 4-nitrofenil- $\alpha$-glükozid szubsztrátumok alkalmazásával.

\subsubsection{Hidrolízis}

Glikozidázok hidrolitikus aktivitását felhasználva is van lehetőség oligoszacharidok előállítására. Poliszacharidok hidrolízisével történő előállításuk endoglikozidázok alkalmazásával történik. A hidrolízis alkalmazásának a frukto-oligoszacharidok (inulin), a malto-oligoszacharidok (keményítő) illetve a xilo-oligoszacharidok (xilán) előállításában van jelentős szerepe (CRITTEnden \& Playne, 1996; Singh \& Singh, 2010). A glikozid hirolízis alkalmazására látható néhány példa a 4 . táblázatban. 


\section{4. táblázat: Példák enzimes hidrolízissel történő oligoszacharid előállításra}

\begin{tabular}{|c|c|c|c|}
\hline Glikozidáz & Szubsztrátum & Termékszerkezet & Referencia \\
\hline endo-inulináz & inulin & $\begin{array}{l}\text { frukto-oligoszacharidok } \\
\text { (fruktóz)n-glükóz } \\
\beta(2-1) \text { és } \alpha(1-2) \text { kötéssel }\end{array}$ & SINGH \& SINGH, 2010 \\
\hline endo-xilanáz & xilán & $\begin{array}{l}\text { xilo-oligoszacharidok } \\
\text { (xilóz)n } \\
\beta(1-4) \text { kötéssel }\end{array}$ & $\begin{array}{l}\text { CRITTENDEN \& } \\
\text { PLAYNE, } 1996\end{array}$ \\
\hline a-amiláz & keményítő & $\begin{array}{c}\text { malto-oligoszacharidok } \\
\text { (Glükóz)n } \\
\alpha(1-4) \text { kötéssel }\end{array}$ & $\begin{array}{l}\text { CRITTENDEN \& } \\
\text { PLAYNE, } 1996\end{array}$ \\
\hline kitozanáz & kitin/kitozán & $\begin{array}{c}\text { kitozán-oligoszacharidok } \\
\text { (2-acetamido-D-glükóz- } \\
\text { 2-amino-D-glükóz)n } \\
\beta(1-4) \text { kötéssel }\end{array}$ & $\begin{array}{l}\text { KIM \& RAJAPAKSE, } \\
2005\end{array}$ \\
\hline $\begin{array}{c}\text { endo-arabinanáz } \\
\text { arabino- } \\
\text { furanozidáz }\end{array}$ & arabinán & $\begin{array}{l}\text { arabino-oligoszacharidok } \\
\text { (arabinóz)n } \\
\alpha(1-5) \text { kötésü lánc, } \\
\alpha(1,2,3,5) \text { elágazásokkal }\end{array}$ & $\begin{array}{l}\text { WESTPHAL et al., } \\
2010\end{array}$ \\
\hline
\end{tabular}

Az inulin egy természetben előforduló poliszacharid, amelyet már sikeresen alkalmaznak fruktóz szirupok előállítására. Az endo-inulináz (EC 3.2.1.7) enzim felhasználásával azonban e szubsztrátumból frukto-oligoszacharidok állíthatók elő. Az inulin hidrolízisével kapott oligoszacharidoknak 2 típusa van: GFn (egy glükóz egységből és hozzá kapcsolódó fruktóz egységekből áll) és Fn típus (csak fruktózból felépülő OS) (VORAGEN, 1998, CHI et al., 2011). A GFn típus bemutatása már a transzfruktozilációs előállítás során megtörtént (2.4.1.1 fejezet). Számos kutató végzett tanulmányt e területen. YUN és munkatársai (1997) dália gumó eredetü inulin hidrolízisét végezték kereskedelmi inulináz enzim készítménnyel (Novozyme 230). A hidrolízis termékeként $\mathrm{DP}_{2}-\mathrm{DP}_{6}$ polimerizáltsági fokú oligoszacharidok képződtek. Ugyanebben az évben egy hasonló publikáció jelent meg a kutatócsoporttól, amelyben már anioncserélő gyantára (Diaion WA30) rögzített Pseudomonas sp. eredetű inulináz enzimet alkalmaztak az inulo-oligoszacharidok előállítására. Később YUN és munkatársai (2000) egy másik hordozót (polisztirénWofatit UF93) alkalmaztak az enzim rögzítéséhez. KIM és munkatársai (1997) szintén egy Pseudomonas sp. eredetü inulináz enzimmel állítottak elő oligoszacharidokat. A Pseudomonas sp. eredetű inulináz gént sikerült klónozni az E. coli HBlOl baktériumba, majd az expresszált enzim felhasználásával inulo-oligoszacharidot előállítani (YUN et al., 1999). NGUYEN és munkatársai (2011) endo-inulinázt rögzítettek és folyamatos biokonvezió segítségével kedvező összetételü oligofruktóz szirupot állítottak elő. A fentieken kívül számos mikrobiális endo-inulinázt vizsgáltak inulo-oligoszacharid előállítására: Penicillium sp. (NAKAMURA et al., 1997), Xanthomonas sp. (PARK et al., 1999), Xanthomonas oryzae (CHO et al., 2001), Aspergillus niger (MUTANDA et al., 2008), Aspergillus ficuum (ZHENGYU et al., 2005). Az inulin alapú ipari méretü inulo-oligoszacharid (Raftilose) előállítást az Orafti cég valósította meg. 
A malto-oligoszacharidok különböző számú glükóz egységekből épülnek fel, melyek $\alpha(1-4)$ glikozidos kötésekkel kapcsolódnak össze (CRITTENDEN \& PLAYNE 1996, SAKO et al., 1999). Előállításuk a keményítő izoamilázzal/pullulanázzal, majd szabályozott $\boldsymbol{\alpha}$-amilázos (EC 3.2.1.1) hidrolízisével történik. Az $\alpha$-amiláz enzim megválasztásának nagy szerepe van a maltooligoszacharidok előállításában, ugyanis a legtöbb $\alpha$-amiláz maltóz és glükóz terméket eredményez. Ma már számos közlemény jelent meg olyan $\alpha$-amilázokról, amelyek a keményítő hidrolízise során csak malto-oligoszacharidokat termelnek (TAKASAKIA et al., 1991a, 1991b; KoBAyASHi et al., 1992; KIM et al., 1995; SATOH et al., 1997; Ali et al., 2001; MesSAOUd et al., 2004; NAGARAJAN et al., 2006).

A malto-oligoszacharidok előnyös fizikai-kémiai tulajdonságainak köszönhetően széles körben alkalmazhatók az iparban bevonószerként, viszkozitás növelőként, kristályosodást gátló anyagként és a kenyér kiszáradását okozó retrogradációs folyamatok csökkentésére (PALACIOS et al., 2004, NAGARAJAN et al., 2006). Számos, elsősorban japán gyártmányú malto-oligoszacharid készítmény kapható a kereskedelmi forgalomban, pl. a Fuji-Oligo (Nihon Shokuhin Kako Inc.) és a Tetrup (Hayashibara Shoji Inc.) (CRITTENDEN \& PlaYne, 1996).

Xilo-oligoszacharidok előállítása az ipari technológiában xilán szubsztrátumból történik, az endo-xilanáz enzim (EC 3.2.1.8) felhasználásával. A xilánt főként kukoricacsutkából extrahálják (CRITTENDEN \& PlAYNE, 1996).

Napjainkban a kitozán-oligoszacharidok iránt is növekedik az érdeklődés. A kitozánoligoszacharidok a kitin vagy a kitozán (de-acetilezett kitin) savas vagy enzimes hidrolízisével állíthatók elő. A specifikusság miatt az enzimes technológiát részesítik előnyben. A kitin és kitozán hidrolízisére számos specifikus kitozanáz enzim (EC 3.2.1.132) (TANABE et al., 2000; CHEN et al., 2005), illetve más nem-specifikus glikozidázok, pl. cellulázok (XIA et al., 2008; LIN et al., 2009), lipázok (MUZZARELLI et al., 1995; SHIN et al., 2001), proteázok (KUMAR et al., 2004) állnak rendelkezésre.

$\mathrm{Az}$ arabino-oligoszacharidok szintén jelentős képviselői az oligoszacharidoknak, melyek prebiotikus tulajdonságát VAN LAERE és munkatársai (2000) bizonyították. Ezen oligomerek előállításával WESTPHAL és munkatársai foglalkoztak (2010). Az arabinán hidrolízisét Chrysosporium lucknowense eredetü arabinohidrolázokkal végezték és nyolc különböző oligoszacharidot sikerült előállítani.

\subsubsection{Glikoziltranszferázok (GT)}

A glikoziltranszferázok (EC 2.4.X.Y) az enzimek egy nagy családját alkotják, melyek monoszacharidok sztereo- és régiospecifikus átvitelét katalizálják egy donor szubsztrátum molekuláról egy akceptor szubsztrátumra (HU \& WALKER, 2002; WEIJERS et al., 2008). 
Különösen gyakoriak azok a GT-ok, amelyeknek müködéséhez aktivált donor molekulára (pl. cukor-nukleotid-foszfátra) van szükség (BRETON et al., 2006). A glikoziltranszferázok mind az oligoszacharidok, mind a poliszacharidok, mind a glikokonjugátumok szintézisében részt vesznek (TANIGUCHI et al., 2002). A glikozil-transzferázok funkciója széleskörü, a szintetizált termékek nagy diverzitással rendelkeznek. Szerepük van az energia raktározásban (glikogén szintézisben), a sejtmembránokat védő poliszacharidok szintézisében, a sejtfelszíni oligoszacharidok előállításában (HU \& WALKER, 2002; BRETON et al., 2006). In vivo körülmények között a glikoziltranszferázok felelősek a sejtfelszíni glikokonjugátumok szintéziséért is (BRETON et al., 2006, SchUMAN et al., 2007; TrinCONE \& GiORDANO, 2006). Akceptor szubsztrátumuk lehet akár a donor molekulával homológ egyszerü monoszacharid vagy egy komplex heteropoliszacharid, mely számos glikozidos kötést tartalmaz (WEIJERS et al., 2008).

Kutatások bizonyították, hogy az emlős glikoziltranszferázokra általánosan jellemző a meghatározott akceptor specifikusság. Ezzel szemben a bakteriális glikoziltranszferázok kevésbé specifikusak. A bakteriális galaktoziltranszferáz enzimeknek, számos akceptora lehet, melyekhez különböző kötésekkel ( $\beta(1-4), \beta(1-3), \alpha(1-3), \alpha(1-6))$ képes a galaktóz kötődni (HENNET, 2002). A bakteriális enzimekre általánosan jellemző, hogy vízben oldódnak, ezzel szemben az emlős GT-ok oldására detergenst kell alkalmazni. Számos emlős GT-t kódoló gént átvittek és expresszáltak már E. coli baktériumban (JOHNSON, 1999; SETO et al., 1999). A bakteriális kifejeztetési rendszer fermentációs költségei jóval alacsonyabbak, mint az eukariótákban vagy rovar sejtvonalban történő expresszálás (JOHNSON, 1999). Számos bakteriális glikoziltranszferázt izoláltak és jellemeztek már. A mikroba eredetű glikoziltranszferázok nagyfokú diverzitást mutatnak transzfer reakciójukat tekintve, és a forrásuk legföképp humán patogén baktériumok, kisebb részük szimbiota baktérium. A GT-ázok egyik jelentős képviselője az eukorióta (főként élesztő) eredetű mannoziltranszferáz (THOMSON et al., 2000). Jelenleg 60 családba sorolják az enzimek e csoportját COUTINHO és HENRISSAT (1999) által felállított szekvencia kritérium alapján. A glikoziltranszferázok mindegyikét jellemezték már a CAZy (Carbohydrate-Active enzymes) adatbázisban (COUTINHO et al., 2003; http://www.cazy.org).

A glikoziltranszferázokat csoportosíthatjuk a katalizált reakció sztereokémiája és a reakcióban résztvevő donor molekula típusa szerint.

A reakció sztereokémiáját tekintve (a glikozidázokhoz hasonlóan) megkülönböztetünk konformációt megtartó és invertáló enzimeket. A glikoziltranszferázok esetében azonban ez nem függ össze közvetlenül azzal, hogy egy adott glikoziltranszferáz mely szerkezeti családhoz tartozik. 


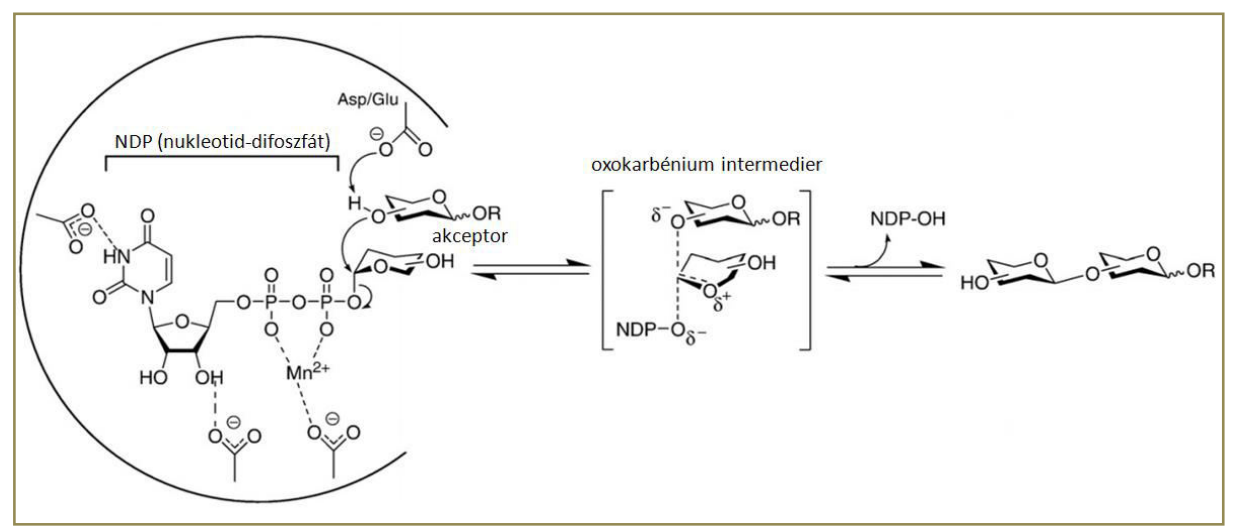

7. ábra: Invertáló glikoziltranszferáz mechanizmusa (WEIJERS et al., 2008)

Az invertáló glikoziltranszferázok esetében a reakciót egy bázisos karboxilát (Asp vagy Glu) indítja el, mely deprotonálja a glikozil akceptor molekulát a (nukleotid-cukor) donor molekula anomer szénatomjának $\mathrm{SN}_{2}$ nukleofil támadásához. Ezt követően, egy oxokarbénium átmeneti állapot jön létre a nukleotid-foszfát és a glikozil donor részvételével. Végül a cukor-donor és az akceptor között kialakuló glikozidos kötés a $C_{1}$ atom konfigurációjának inverziójához vezet (7. ábra).

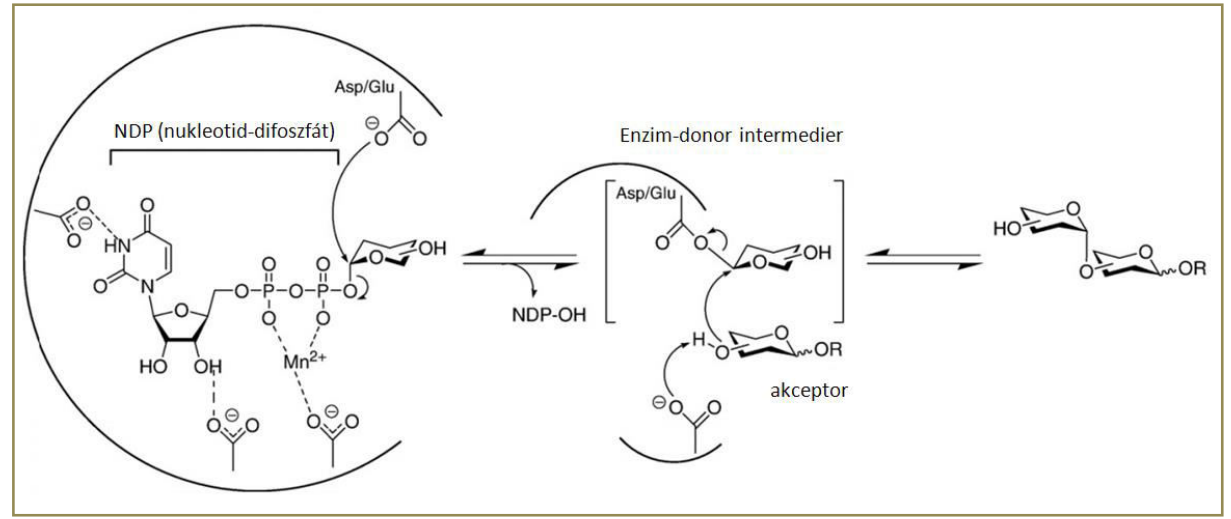

8. ábra: Megtartó glikoziltranszferáz mechanizmusa (WEIJERS et al.,2008)

A megtartó glikoziltranszferázok mechanizmusa a mai napig nem tisztázott teljesen, azonban a leginkább támogatott elmélet a „dupla kicserélődési mechanizmus”-on alapszik (8. ábra). Eszerint elsőként a karboxilát vég (Asp vagy Glu) közvetlen $\mathrm{SN}_{2}$ nukleofil támadása történik a cukor-nukleotid donor anomer szénatomjára ( $\beta$-enzim-glikozil intermedier, első inverzió), majd a glikozil akceptor (egy másik karboxilát vég által aktivált) másodlagos $\mathrm{SN}_{2}$ támadása következik az anomer szénatom ellenkező oldalára, ezáltal kialakítva az a-glikozidos kötésü oligoszacharid terméket (másodlagos térszerkezet inverzió).

A katalitikus reakcióban részt vevő donor molekula szerint megkülönböztetünk Leloir és non-Leloir transzferázokat. A Leloir glikoziltranszferázok esetében a donor molekulák aktivált 
szénhidrátok, azaz cukor-nukleotidok. E szubsztrátumok előállítása nukleozid mono- és difoszfátok (CMP, UDP, GDP, TDP) hozzáadásával történik. A non-Leloir transzferázok alkalmazásánál nincs szükség aktivált donor molekulára a transzfer reakció lejátszódásához. Ez esetben kétféle donor molekula lehetséges: cukor-foszfátok (amelyeket direkt foszforilációval hoznak létre) és nem aktivált szénhidrátok pl. szacharóz és keményítő származékok (WEIJERS et al., 2008).

\section{5. táblázat: Kereskedelmi forgalomban kapható glikoziltranszferáz enzimek} (WEIJERS et al., 2008)

\begin{tabular}{|c|c|c|}
\hline Enzim & Forrás & Forgalmazó \\
\hline$\beta(1-4)$-galaktoziltranszferáz & tehéntej eredet & Sigma-aldrich \\
\hline$\beta(1-4)$-galaktoziltranszferáz & $\begin{array}{c}\text { szarvasmarha/humán eredet, } \\
\text { rekombináns, } \\
\text { Saccharomyces cerevisiae-ben expresszálva }\end{array}$ & Sigma-aldrich \\
\hline ß (1-4)-galaktoziltranszferáz & $\begin{array}{l}\text { szarvasmarha/humán eredet, rekombináns, } \\
\text { Spodoptera frugiperda-ban expresszálva }\end{array}$ & $\begin{array}{l}\text { Calbiochem } \\
\text { /Merck }\end{array}$ \\
\hline $\begin{array}{l}\alpha-(1-3)- \\
\text { galaktoziltranszferáz }\end{array}$ & $\begin{array}{l}\text { rekombináns, } \\
\text { Escherichia coli baktériumban expresszálva }\end{array}$ & Sigma-aldrich \\
\hline$\alpha(1-3)$-fukoziltranszferáz & $\begin{array}{l}\text { rekombináns, } \\
\text { Pichia pastoris élesztőben expresszálva }\end{array}$ & Sigma-aldrich \\
\hline$\alpha(1-2)$-mannoziltranszferáz & $\begin{array}{l}\text { Saccharomyces cerevisiae eredet,rekombináns, } \\
\text { Escherichia coli baktériumban expresszálva }\end{array}$ & $\begin{array}{l}\text { Calbiochem } \\
\text { /Merck }\end{array}$ \\
\hline$\alpha(2-3)$-szialiltranszferáz & $\begin{array}{l}\text { patkány máj eredet,rekombináns, } \\
\text { Spodoptera frugiperda-ban expresszálva }\end{array}$ & $\begin{array}{l}\text { Calbiochem } \\
\text { /Merck }\end{array}$ \\
\hline$\alpha(2-6)$-szialiltranszferáz & $\begin{array}{l}\text { humán eredet, } \\
\text { rekombináns, } \\
\text { Spodoptera frugiperda-ban expresszálva }\end{array}$ & $\begin{array}{l}\text { Calbiochem } \\
\text { /Merck }\end{array}$ \\
\hline$\alpha(2-3)$-szialiltranszferáz & $\begin{array}{l}\text { Photobacterium phosphoreum eredet, } \\
\text { rekombináns, } \\
\text { E. coli baktériumban expresszálva }\end{array}$ & Japan Tobacco \\
\hline$\alpha(2-6)$-szialiltranszferáz & $\begin{array}{c}\text { Photobacterium damselae eredet, } \\
\text { rekombináns, } \\
\text { E. coli baktériumban expresszálva }\end{array}$ & Japan Tobacco \\
\hline fruktoziltranszferáz & Ismeretlen & X-Zyme \\
\hline
\end{tabular}

A régio- és sztereospecifitásuk, a magas hozam, a nagyfokú akceptor specifikusságuk miatt a GT-okat széleskörben alkalmazzák oligoszacharidok előállítására (MAITIN \& RASTALL, 2007). Új oligoszacharidok előállításában való alkalmazásukat azonban gátolja, hogy még kevés ismeret áll rendelkezésre arról, hogy a glikoziltranszferázok részére milyen mértékben kedveznek egyes szubsztrátumok. A GT-ázok szubsztrátum specifikusságának módosítását a kutatók eddig fehérjemérnökség segítségével próbálták megoldani, még kevés sikerrel (HOFFMEISTER et al., 2002). Napjainkban, a kereskedelmi forgalomban még csak korlátozott számú glikoziltranszferáz enzim áll rendelkezésre (5. táblázat). Ebből az következik, hogy a legtöbb esetben még nincs olyan GT enzim, amely segítségével egy kívánt glikozidos kötés kialakítása megvalósítható. 


\subsubsection{Szintézis non-Leloir glikoziltranszferázokkal}

A glikoziltranszferázok egyik nagy csoportját alkotják a non-Leloir glikoziltranszferázok.

Az ide tartozó transzferáz enzimek esetében a katalizált reakcióban a következő szubsztrátumok szerepelhetnek donor molekulaként: szacharóz, keményítőszármazékok és cukorfoszfátok.

Általánosan igaz e transzferáz csoportra, hogy emlős szervezetekben ritkán fordulnak elő. Számos non-Leloir enzim jellemzése még hiányzik, felhasználási lehetőségeik még feltáratlanok (WEIJERS et al., 2008, FilicE \& MARCIELLO, 2013). Ennek ellenére nagy biotechnológiai potenciállal rendelkeznek, mely annak köszönhetö, hogy az oligoszacharid szintézishez nem igényelnek nagyon drága aktivált donor szubsztrátumot. Hátrányuk, hogy mellékreakcióként hidrolízis reakciót is katalizálhatnak (SEIBEL et al., 2006, FILICE \& MARCIELLO, 2013).

A non-Leloir típusú transzferáz enzimeknek fő képviselői a glükoziltranszferázok, fruktoziltranszferázok és a ciklodextrin-glükanotranszferáz (FILICE \& MARCIELLO, 2013). Szükséges kiemelni, hogy a CAZy adatbázis szerint e három enzim típus nem a glikoziltranszferázok, hanem a glikozidázok csoportjába tartozik.

A fruktoziltranszferázok a szacharóz molekula fruktozil részének átvitelét katalizálják. A fruktoziltranszferázokat CAZy adatbázis a GH 32 és GH 68 glikohidroláz családba sorolja (http://www.cazy.org). Főbb képviselői: levánszukráz (EC 2.4.1.10), inuloszukráz (EC 2.4.1.9), szacharóz:szacharóz 1-fruktoziltranszferáz (EC 2.4.1.99), fruktán:fruktán 1-fruktoziltranszferáz (EC 2.4.1.100), szacharóz:szacharóz 6-fruktoziltranszferáz (EC 2.4.1.-), fruktán-fruktán 6Gfruktoziltranszferáz (EC 2.4.1.243.). Egyes frutkoziltranszferáz enzimek felhasználásával fruktooligoszacharidok szintetizálhatók. A fruktoziltranszferázok által katalizált reakció sémája a 9. ábrán látható.

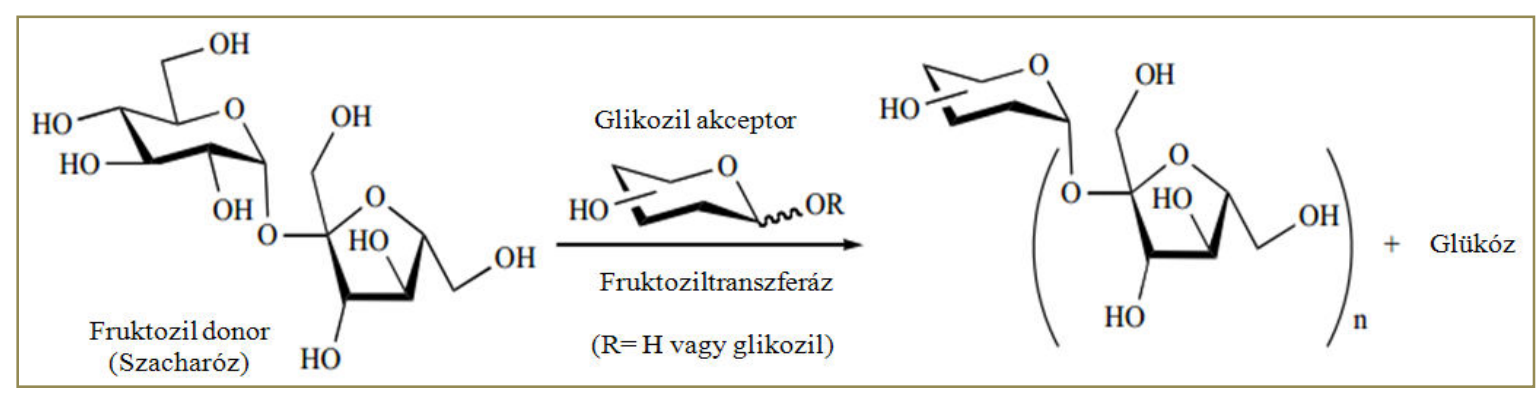

\section{9. ábra: A transzfruktoziláció mechanizmusa (FILICE \& MARCIELLO, 2013)}

A levánszukrázok a legjobban jellemzett fruktoziltranszferáz enzimek, amelyek a $\beta(2-6)$ kötésü fruktóz homopolimer (néhány $\beta(1-6)$-os elágazással), a leván szintéziséért felelősek. A levánok egyre nagyobb figyelmet kapnak kedvező élettani tulajdonságaiknak köszönhetően. Antikarcinogén és hipokoleszterinémiás tulajdonsággal rendelkeznek, továbbá jelentős az immunrendszerre gyakorolt kedvező hatásuk is. (PARK et al., 2003; GONCALVES et al., 2015). 
A leván a termelő organizmusok (főként baktéiumok) számára tartalék szénforrásként szolgál, emellett védi a sejtmembránt a szárazság és a magas hőmérséklet okozta stressz ellen (Chambert et al., 1974; Vijn \& SMEeKens, 1999; VAn Hijum et al., 2006). Már régóta ismert, hogy a levánszukrázok a transzfruktozil reakció során többféle szénhidrátot képesek akceptorként felismerni, akár monoszacharidokat is, amellyel különböző szacharóz analógok állíthatók elő (HESTRIN et al., 1956). A szacharóz analóg molekulák donor szubsztrátumai lehetnek az enzimnek, így különböző szerkezetü fruktozil-oligoszacharidok szintetizálhatók (TANAKA et al., 1981; SEIBEL et al., 2005).

A Bacillus megaterium DSM 319 levánszukráz ígéretes biokatalizátor frukto-oligoszacharidok előállítására, melyet elsőként a Braunschweigi Müszaki Egyetemen BIEDENDIECK (2007) azonosított. Az extracelluláris enzim molekulatömege kb. 52 kDa és 484 aminosavból áll (BIEDENDIECK, 2007). HOMANN (2009) és ZWERENZ (2011) rekombináns levánszukrázzal tanulmányozta az oligoszacharidok szintézisét. Megállapították, hogy az enzim képes fruktóz egység átvitelére mannózra, galaktózra, galakturonsavra, xilózra és fukózrailletve palatinózra. Kutatómunkámban ezen enzimet tanulmányoztam további lehetséges akceptorokat felhasználva (4.2.3 fejezet).

Az inuloszukráz és a szacharóz:szacharóz 1-fruktoziltranszferáz szintén jelentős fruktooligoszacharid előállítás szempontjából. Ezen enzim típusok (a $\beta$-fruktofuranozidázhoz hasonlóan) a szacharózból $\beta(1-2)$ kötésű oligoszacharidok szintézisét katalizálják. E két enzim típusnál, a szintetizált szénhidrátok polimerizáltsága eltérő (BALKEN et al., 1991).

A glükoziltranszferázok (dextránszukráz, mutánszukráz EC 2.4.1.5, alternánszukráz EC 2.4.1.140) szintén képesek a szacharózt szubsztrátumként felismerni. Müködésük során a szacharóz glükóz egységéből (a fruktóz molekula felszabadulása mellett) szintetizálnak oligoszacharidot. (PlOU et al., 2002; MONSAN \& AURIOL, 2004). Ezeket az extracelluláris enzimeket föként a Leuconostoc, Streptococcus és Lactobacillus fajok termelik (DUNICAN \& SEeley, 1963; ChludzinsK et al., 1974; ArgüEllo-Morales et al., 2000; PuRAMA \& GoyAl, 2005). A CAZy rendszer szerint ezek az enzimek a glikozid hidrolázok GH 70 családjába tartoznak (www.cazy.org).

A glükoziltranszferáz csoportba tartozó dextránszukráz enzim terméke az elágazó láncú glükóz heteropolimer, a dextrán. A kötések túlnyomó része (több mint 50\%-ban) a-(1-6)-os, kisebb részben $\alpha(1-2)$; $\alpha(1-3)$; $\alpha(1-4)$ glükozidos kötéseket is tartalmaz. Molekulatömege 500-6000 kDa tartományban változhat (MONSAN \& AURIOL, 2004). A mutánszukráz enzimek ugyanabba az enzimcsoportba (EC 2.4.1.5) tartoznak, ezek azonban a mután szintézisét katalizálják. A mután a dextránnal szemben föként $\alpha(1-3)$-as kötéseket tartalmaz (ARGÜELLO-MORALES et al., 2000). 
A glükoziltranszferázok aktív centruma nagyfokú specifitást mutat a szacharóz iránt, ezért szacharóz analógok nem vehetnek részt donor szubsztrátumként a reakcióban (SEIBEL et al., 2006; WEIJERS et al., 2008). E tulajdonságuk korlátozza oligoszacharid szintézisre való alkalmazhatóságukban. Lehetőség van azonban arra, hogy az enzim a szacharóz glükóz részét egy másik (szacharóztól eltérő kémiai szerkezetü) akceptor molekulára szállítsa, ezzel kis molekulatömegü oligoszacharidokat szintetizálva (ROBYT \& WALSETH, 1978; ROBYT \& EKLUND, 1983). Kimutatták már, hogy a fruktóz is lehet akceptora az enzimnek, és így leukróz diszacharid szintetizálható (REH et al., 1996; BuCHHOLz et al., 1998). Plou és munkatársai (2002) Leuconostoc mesenteroides eredetű dextránszukrázzal $\alpha(1-2)$ kötésű glükooligoszacharidokat szintetizáltak, 1-O- $\alpha$-D-glükopiranozid akceptor alkalmazásával.

Ismeretes olyan glükoziltranszferáz is, amely csak maltóz szubsztrátum jelenlétében képes oligoszacharidok (panóz, izomaltóz) szintézisére, az $\alpha$-glükozidáz mechanizmusához hasonlóan (HAYASHI et al., 1994).

A ciklodextrin-glükanotranszferáz (CGTáz, EC 2.4.1.19, GH 13 glikozidáz család) enzim a ciklomaltodextrin előállítására használt non-Leloir transzferáz. Ez az enzim a keményítő és a maltodextrin $\alpha(1-4)$-es kötésű szakaszait (6 - 9 glükóz molekula) nem redukáló láncvégekre viszi át, ciklikus, nem redukáló gyürüs ciklodextrineket képezve (TONKOVA, 1998; VAN DER MAAREL et al., 2002). Az így szintetizált termékek a 6, 7 vagy 8 glükóz egységből álló, $\alpha(1-4)$-es kötésü ciklikus oligoszacharidok, melyeket $\alpha, \beta$ vagy $\gamma$ ciklodextrineknek neveznek. A ciklodextrinek előállítására különböző ipari méretü eljárásokat valósítottak meg, köztük a Chinoin által kifejlesztett komplexálló oldószeres (toluol) eljárást. A legújabb fejlesztő kutatások eredménye a kombinált rögzített enzimeket alkalmazó folyamatos eljárás. A legnagyobb gyártók japán cégek (Nihon Shokuhin Kako, Ensuiko Sugar Refining Co., Asahi Kasei Kagyo Co.). Sokrétü felhasználhatósága miatt folyamatosan növekszik az igény a ciklodextrinek, elsősorban $\beta$-ciklodexrinek iránt. E szénhidrát képes a folyékony vagy illó anyagok stabilizálására mind élelmiszerek mind vegyszerek esetében, olajok és zsírok emulgálására. Használatával megakadályozható egyes anyagok oxidációja és fotodegradációja, emellett képes elfedni a keserü ízt a gyógyszerekben és élelmiszerekben. A CGT-áz enzimet a glükozil-szacharóz előállítására is alkalmazzák. E triszacharid szintéziséhez szacharóz és maltóz szubsztrátumokat alkalmaznak. A reakció során az enzim a maltóz glükóz részét a szacharózra viszi át (CRITTENDEN \& PLAYNE, 1996).

A CGTázok jellemzően mikroba eredetű (főként Bacillus fajok által termelt) extracelluláris enzimek. A ciklodextrin képzésben a CGTázoknak nagyobb affinitása van diszacharid szubsztrátmokra, mint monoszacharidokra, tehát az akceptor kötőhelye legalább 2 glükopiranóz egységet képes felismerni. Különböző diszacharidok, mint az izomaltóz, gentiobióz, turanóz, 
maltulóz, izomaltulóz, cellobióz és a szacharóz az enzim lehetséges akceptorai, míg a trehalóz és a melibióz (melyeknek szintén van glükóz része) nem (PLOU et al., 2002). Emellett SHIBUYA és munkatársai (2003) kimutatták, hogy Bacillus stearothermophilus eredetü CGTázzal lehetséges különböző transzfer termékek elöállítása, ciklomaltohexaóz donor és ciklikus tetraszacharid akceptor molekula alkalmazásával.

A foszforilázokat szintén a non-Leloir glikoziltranszferázok közé sorolják, melyek képesek glikozidos kötések hasítására illetve szintézisére. A CAZy rendszer szerinti besorolás alapján a foszforilázok egyes tagjai a glikozid hidrolázok (pl. szacharóz-foszforiláz EC 2.4.1.7, GH 13, lakto- $N$-bióz-foszforiláz EC 2.1.4.211, GH 112), míg mások a glikoziltranszferázok (pl. glikogén-foszforiláz EC 2.4.1.1, GT 35, trehalóz-foszforiláz EC 2.4.1.231, GT 35).

A foszforilázokat az teszi alkalmassá hatékony oligoszacharid előállításra, hogy az általuk katalizált defoszforilálási reakció reverzibilis (NAKAI et al., 2013). A reverz reakcióban a cukorfoszfát donor molekulaként szerepel, melyet az akceptor szénhidrát molekulával párosítva (nagy specifitással) oligoszacharidok szintetizálhatók (10. ábra). A legtöbb foszforiláz a glükozilkötések foszforilízisét katalizálja, $\alpha$ - vagy $\beta$-glükóz-1-foszfátot szintetizálva. Kisszámú képviselöik a galaktozil- vagy N-acetil-glükózaminil-kötések defoszforilálását végzik, azonban ha víz nem vesz részt a reakcióban és a glikozil-foszfát szubsztrátum kötési energiája alacsony, ez a reakció reverzibilis is lehet (WEIJERs et al., 2008).

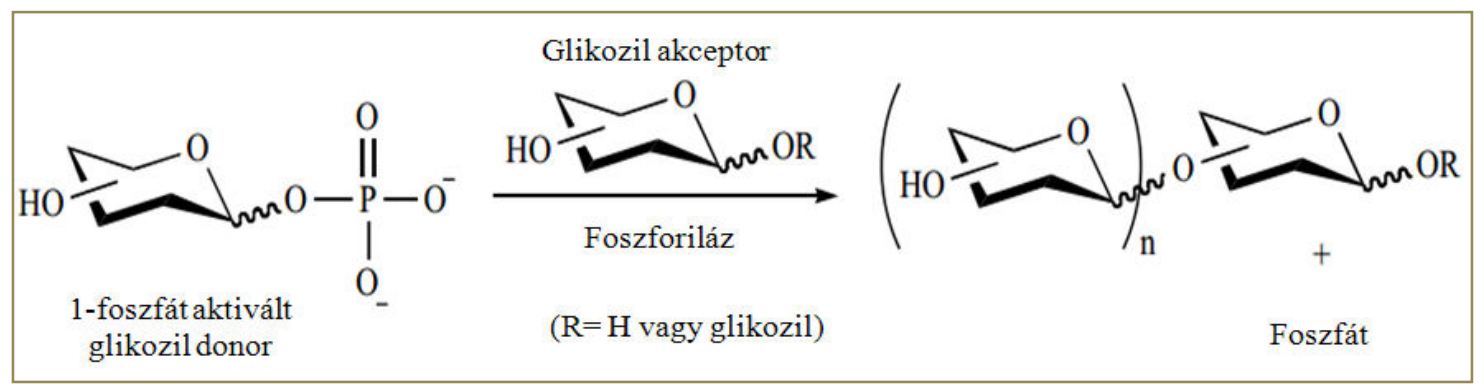

10. ábra: A foszforilázok hatásmechanizmusa (FILICE \& MARCIELLO, 2013)

A foszforiláz típusától függően a reakció végbemehet az anomer szénatom inverziójával és megtartásával is. Szubsztrátumai lehetnek $\alpha$ - és $\beta$-glikozidok, oligo- és poliszacharidok. Többségük a glükozil-foszforilázok családjába tartozik, amelyek a glükóz-1-foszfát és az akceptor glikozid, glikozil-glikoziddá és szervetlen foszfáttá történő reverzibilis konverzióját katalizálják. A foszforilázok mindegyike nagy specifitással rendelkezik a donor szubsztrátum iránt, de kevésbé specifikusak az akceptor molekulára, így az oligoszacharidok széles körét képesek előállítani. Egyes prokarióta eredetü glikoziltranszferázok donor molekulái lehetnek mono- és difoszfolipidek is (HU \& WALKER, 2002).A foszforilázok alkalmazása oligoszacharidok szintézisére még korlátozott, azonban napjainkban egyre növekszik a 
foszforilázokról szóló tudományos ismeretünk (LULEI-GOEDL \& NIDETZKY, 2010; NAKAI et al., 2010; NAKAI et al., 2013).

A non-Leloir enzimek nagy biotechnológiai potenciállal rendelkeznek, mivel nem igényelnek drága aktivált szubsztrátumokat. Hátrányuk, hogy mellékreakcióként hidrolízis is felléphet, amely akadályozza teljeskörü kiaknázásukat (WEIJERS et al., 2008).

\subsubsection{Szintézis Leloir glikoziltranszferázokkal}

A Leloir típusú glikoziltranszferázok felelősek az emlős szervezetekben a legtöbb sejtfelszíni glikokonjugátum illetve a növények, gombák és baktériumok sejtfalában található poliszacharidok szintéziséért. Az általuk katalizált reakciókban (11. ábra) aktivált nukleotidmono- vagy difoszfát szénhidrátok (pl. UDP-Glc, UDP-Gal, UDP-GlcNAc, UDP-GalNAc, UDP-Xyl, UDP-GlcA, GDP-Man, GDP-Fuc, CMP-sziálsav) szerepelnek donor molekulaként. A szubsztrátum nukleotid része nagy szerepet játszik a glikoziltranszfer reakció során. E molekularészletnek köszönhető a szubsztrátum enzimhez való kötődése (közvetlenül vagy divalens kation révén), továbbá nagy szerepet játszik (lehasítása után) az enzim eredeti állapotára való tekeredésben (SEIBEL et al., 2006).

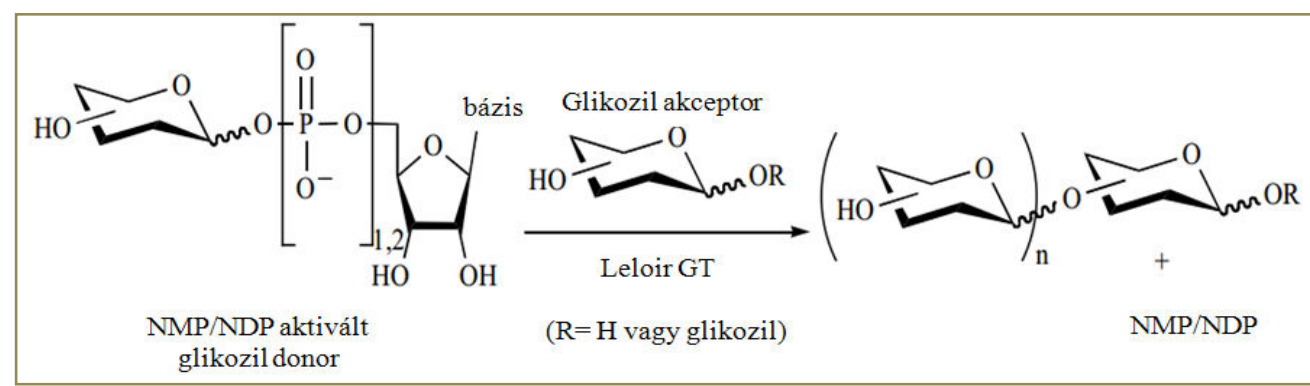

11. ábra: A Leloir glikoziltranszferázok mechanizmusa (FILICE \& MARCIELLO, 2013)

A Leloir transzferázok szerkezetük alapján két nagy szerkezeti „,szupercsalád”-ba oszthatók: GT-A és GT-B. A két csoport elsősorban másodlagos szerkezetben (eltérő fehérje feltekeredés), az aktív centrumban és katalitikus hatásmechanizmusban különbözik.

A Leloir transzferázok a befogadott szubsztrátum és a monoszacharid transzfer diverzitása alapján nagyon elönyösek, így ezekkel változatos oligoszacharid szintézis valósítható meg. Alkalmazásukat jelentősen gátolja a reakcióhoz szükséges cukor-nukleotid szubsztrátum, amely nagy mennyiségben még nem kapható a kereskedelmi forgalomban. Ez kritikus pontja a léptéknövelés megvalósításának. A probléma megoldására jelenleg is folynak kutatások két területre fókuszálva: (1) a természetes cukor-nukleotidok in situ regenerálása, (2) mesterséges cukor-nukleotidok előállítása, melyeknek szerkezete egyszerübb és olcsóbb az előállításuk (WEIJERS et al., 2008). A transzferáz enzimek közül a $\beta(1-4)$-galaktoziltranszferáz, $\alpha(2-3) /(2-6)$ - 


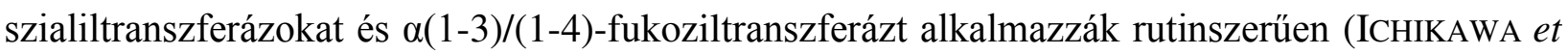
al., 1992; CROUT \& VIC, 1998).

\subsubsection{Bifidobacterium eredetü glikozidázok jelentősége}

A bifidobaktériumok nem spórázó, $\mathrm{Gram}^{+}$baktériumok, amelyek az emberi és állati bélrendszer lakói (PoKUSAEVA et al., 2011). E baktériumok táplálékául szolgálnak azon összetevők, amelyek a tápcsatorna felső szakaszán nem bomlanak le és nem szívódnak fel. A közlemények túlnyomó többsége egészségügyi hatásaikra, valamint az élelmiszergyártásba történő bevonásukra összpontosít, azonban az utóbbi időben egyre növekszik azon tanulmányok száma, amelyek a Bifidobacterium nemzetség glikozidáz enzimeivel foglalkozik. E hidrolázoknak amellett, hogy szerepük van a vastagbélbe jutó szénhidrátok hasznosításában, (akár új) prebiotikus szénhidrát/oligoszacharid szintézis biokatalizátorai is lehetnek.

Oligoszacharid szintézis kapcsán, eddigi tanulmányok főként a bifidobaktériumok $\alpha$ - és $\beta$-galaktozidáz enzimeivel kapcsolatban jelentek meg (6. táblázat).

RABIU és munkatársai (2001) különböző bifidobaktérium fajok/törzsek (Bifidobacterium angulatum, Bifidobacterium bifidum BB-12, Bifidobacterium adolescentis ANB-7, Bifidobacterium infantis DSM-20088, Bifidobacterium pseudolongum DSM-20099) felhasználásával $\beta$-galaktozidázt tartalmazó nyers enzimpreparátumot állítottak elő és alkalmazták galakto-oligoszacharid szintézisre. Fermentációs tesztekkel azt is bizonyították, hogy a bifidobaktérium eredetü $\beta$-galaktozidázzal szintetizált oligoszacharidokon a célmikroorganizmusok jobban szaporodnak, mint kereskedelmi forgalomban kapható galaktooligoszacharidon (Oligomate 55). Hasonló eredményt értek el TzORTzIS és munkatárssai (2005) akik a Bifidobacterium bifidum NCIMB41171 törzs teljes sejttömegét felhasználva szintetizáltak laktózból galakto-oligoszacharidot, feltehetően a sejt $\beta$-galaktozidáz enzimének köszönhetően. Ök szintén azt tapasztalták, hogy az általuk szintetizált oligoszacharidot jobban tudta hasznosítani a teszt organizmus, mint a kereskedelmi forgalomban kapható galaktooligoszacharid készítményeket. Ezek az eredmények is alátámasztják a Bifidobacterium eredetü enzimek oligoszacharid szintézisben játszott szerepének további tanulmányozásának jelentőségét. 
6. táblázat: Oligoszacharid szintézist mutató bifidobaktérium eredetű enzimek

\begin{tabular}{|c|c|c|}
\hline Enzim & Forrás & Referencia \\
\hline Q-galaktozidáz & Bifidobacterium adolescentis & VAN LAERE et al., 1999; RABIU et al., 2001 \\
\hline a-galaktozidáz & $\begin{array}{c}\text { Bifidobacterium adolescentis } \\
\text { (rekombináns) }\end{array}$ & VAN DEN BROEK et al., 1999 \\
\hline$\alpha$-galaktozidáz & Bifidobacterium breve (rekombináns) & ZHAO et al., 2008 \\
\hline 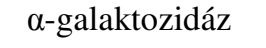 & Bifidobacterium bifidum & GoULAS et al., 2007 \\
\hline 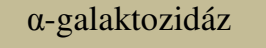 & Bifidobacterium bifidum (rekombináns) & GOULAS et al., 2009 \\
\hline$\beta$-galaktozidáz & Bifidobacterium angulatum & RABIU et al., 2001 \\
\hline$\beta$-galaktozidáz & Bifidobacterium bifidum & $\begin{array}{l}\text { TZORTZIS et al., } 2005 \\
\text { GOULAS et al., } 2007\end{array}$ \\
\hline$\beta$-galaktozidáz & Bifidobacterium infantis & $\begin{array}{l}\text { RABIU et al., } 2001 \\
\text { ROY et al., } 2002\end{array}$ \\
\hline$\beta$-galaktozidáz & Bifidobacterium infantis(rekombináns) & HUNG \& LEE, 2002 \\
\hline$\beta$-galaktozidáz & Bifidobacterium longum & $\begin{array}{c}\text { HSU et al., } 2007 \\
\text { SCHWAB et al., } 2011\end{array}$ \\
\hline$\beta$-galaktozidáz & Bifidobacterium pseudolongum & RABIU et al., 2001 \\
\hline$\alpha$-glükozidáz & Bifidobacterium breve & POKUSAEVA et al., 2009 \\
\hline $\begin{array}{l}\text { endo- } \alpha-\mathrm{N} \text {-acetil- } \\
\text { galaktózaminidáz }\end{array}$ & Bifidobacterium longum & ASHIDA et al., 2010 \\
\hline
\end{tabular}

PoKUSAEVA és munkatársai (2009) Bifidobacterium breve UCC2003 eredetü a-1,6-glükozidázzal szintetizáltak oligoszacharidokat palatinóz, trehalulóz, trehalóz, pannóz és izomaltotrióz szubsztrátumokon.

Reverz hidrolízis reakciót katalizáló bifidobaktérium eredetű glikozidázról ASHIDA és munkatársai (2010) számoltak be, Bifidobacterium longum eredetű endo- $\alpha$ - $N$-acetilgalaktózaminidázt állítottak elő és szintetizáltak e reakció felhasználásával oligoszacharidokat.

Még számos olyan Bifidobacterium eredetü enzim van, amelyet nem tanulmányoztak oligoszacharid szintézis céljából. Feltételezhető, hogy ezek az enzimek további transzglikozilációs és/vagy reverz hidrolízis reakciókban olyan di/oligoszacharidokat eredményeznek, amelyek integrált szinbiotikum összetevőjeként alkalmazhatók. Az integrált szinbiotikum kifejezés azt jelenti, hogy prebiotikus összetevőként a szinbiotikum olyan szénhidrátot tartalmaz, amelyet a probiotikus mikroorganizmus enzimével/enzimeivel szintetizálnak 


\subsubsection{Pectinex ultra enzimkészítmény}

A készítmény kereskedelmi forgalomban kapható, megfelel a FAO/WHO, JECFA és FFC által szabott követelményeknek, így az élelmiszergyártásban széles körben alkalmazzák. A készítményen forgalomba hozatal előtt steril szürést végeznek, így gyakorlatilag mikrobamentes. Főként gyümölcslevek gyártásánál használják léhozam növelése céljából. A specifikáció alapján a készítmény Aspergillus aculeatus eredetü pektin-transzeliminázt, poligalakturonázt és pektinészterázt valamint kis mennyiségben cellulázt és hemicellulázt tartalmaz.

Az utóbbi időben számos publikáció jelent meg arról, hogy a Pectinex ultra egyéb kísérő aktivitásokkal is rendelkezik, amelyek alkalmasak különböző oligoszacharidok előállítására (7. táblázat).

\section{7. táblázat: Pectinex ultra alkalmazása oligoszacharidok szintézisére}

\begin{tabular}{|c|c|c|c|}
\hline Enzim & Szubsztrátum & Termék & Referencia \\
\hline $\begin{array}{l}\text { szacharóz:szacharóz } \\
\text { 1-fruktoziltranszferáz }\end{array}$ & szacharóz & FOS & $\begin{array}{c}\text { HANG \& WOODAMS, } 1995 \\
\text { CSANÁDI \& SISAK, } 2006 \\
\text { GHAZI et al., } 2007\end{array}$ \\
\hline $\begin{array}{l}\text { szacharóz:szacharóz } \\
\text { 1-fruktoziltranszferáz }\end{array}$ & melasz (szacharóz) & FOS & GHAZI et al., 2006 \\
\hline $\begin{array}{l}\text { szacharóz:szacharóz } \\
\text { 1-fruktoziltranszferáz }\end{array}$ & $\begin{array}{l}\text { cukkorrépa eredetü } \\
\text { szirup (szacharóz) }\end{array}$ & FOS & GHAZI et al., 2006 \\
\hline$\beta$-galaktozidáz & laktóz & GOS & DEL-VAL et al., 2001 \\
\hline$\beta$-galaktozidáz & laktulóz & laktulóz-oligoszacharid & FERNANDEZ-RODRIGEZ et al., 2011 \\
\hline poli-galakturonáz & poli-galakturonsav & oligo-galakturonsav & Сомво et al., 2012 \\
\hline kitozanáz & kitozán & kito-oligoszacharid & CABRERA \& CUTSEM, 2005 \\
\hline
\end{tabular}

Elsőként HANG és WoODAMs 1995-ben írta le, hogy az enzimkészítmény képes transzfruktozilációs reakciót katalizálni, majd 1996-ban megállapították az oligoszacharid szintézis hőmérséklet $\left(65^{\circ} \mathrm{C}\right)$ és pH $(5,0$ - 6,0) optimumát. Később GHAZI és munkatársai (2007) tisztították és jellemezték a reakciót katalizáló fruktoziltranszferáz enzimet (szacharóz:szacharóz 1-fruktoziltranszferáz). HANG és WoODAMs (1995) által leírt eredményekhez képest ők szélesebb intervallumot állapítottak meg pH és hőmérséklet optimumnak (pH 5,0 - 7,0, 50 - 70 $\left.{ }^{\circ} \mathrm{C}\right)$. Továbbá meghatározták az enzim hő- és pH-stabilitását ( $\mathrm{pH}$ 5,0 - 7,0, $60{ }^{\circ} \mathrm{C}$ ), a kémiai stabilitását, kinetikai jellemzőit és szubsztrátum specifitását is. Eredményeik alapján az enzim szubsztrátuma lehet a szacharóz, raffinóz, 1-kesztóz és a nisztóz. Más szénhidrátok, pl. turanóz, cellobióz, melibióz, leukróz, metil- $\alpha$-D-glükopiranozid és sztachióz nem kiindulási anyagai a fruktoziltranszferáznak. A transzfrukotozilációs reakciót felhasználva szacharóz szubsztrátumon 1-kesztózt, nisztózt és fruktozil-nisztózt szintetizáltak. Magyar kutatók is alkalmazták az 
enzimkészítmény transzfruktozilációs reakcióját frukto-oligoszacharidok előállítására. CSANÁDI és SISAK 2006-ban sikeresen rögzítette az enzimkészítményt Amberlite IRA900 Cl anioncserélőn, melyet kombináltak az adszorbeált fehérjék közötti keresztkötéssel.

A Pectinex ultra $\beta$-galaktozidáz enzimet is tartalmaz, amelyet elöször DEL-VAL és munkatársai publikáltak (2001). Ök 6'-galaktozil-laktózt szintetizáltak az enzim segítségével. Később ASLAN és TANRISEVEN (2007) kovalens kötéssel rögzítette e $\beta$-galaktozidáz enzimet Eupergit C hordozóra. Megállapították, hogy rögzítés során nem változik az enzim hőmérséklet és pHoptimuma, viszont jobb stabilitást mutat. 2009-ben CARDELLE-COBAS és munkatársai (2009) különböző szénhidrát származékokat (galaktozil-glicerolt és digalaktozil-glicerolt) szintetizáltak e készítménnyel. FERNANDEZ-RODRIGEZ és társai (2011) megállapították, hogy az enzim által katalizált transzgalaktozilációs reakcióban lehetséges szubsztrátum a laktulóz.

A készítmény hidroláz aktivitásait is tanulmányozták már oligoszacharid előállítás céljából. CABRERA és CUTSEM (2005) kitozán hidrolízisével kito-oligoszacharidokat állítottak elő. COMBO és munkatársai (2012) a készítmény pektináz aktivitását felhasználva poligalakturonsavból oligogalakturonsavat képeztek.

\subsubsection{Maillard reakció}

A Maillard reakció kémiai kondenzációs reakció, amely sorána redukáló cukrok reakcióba lépnek fehérjék/enzimek/nukleinsavak/foszfolipidek szabad amino csoportjaival (REDDY \& BEYAZ, 2006). E reakció végbemenetele kedvező lehet egyes élelmiszerek előállításánál.Ez a hő hatására kialakuló folyamat felelős az élelmiszerek egyes íz- és aromaanyagainak kialakulásáért. A Maillard reakciónak köszönhetően az élelmiszerek textúrája is szabályozható (MONNIER, 2003).

Az elmúlt években azonban számos tanulmány jelent meg a Maillard reakció szerepéröl az öregedésben és a megbetegedésekben (BROWNLEE, 1992; BAILEY et al., 1998). A reakció során keletkező úgynevezett „előrehaladott glikációs végtermékek” (,advanced glycation endproducts”, AGEs) ugyanis nagy szerepet játszanak egyes betegségek kialakulásában, pl. az Alzheimer-kór, Parkinson-kór, diabétesz, szürkehályog stb. (REDDY \& BEYAZ, 2006). E betegségek kezelésére/megelőzésére, számos olyan vegyületet (pl. aminoguanidint) kifejlesztettek, amelyek képesek a Maillard reakció és így az AGE-k képződésének gátlására. Néhányuk már klinikai tesztelés alatt áll (REDDY \& BEYAZ, 2006).

A Maillard reakció hatással lehet az enzimes folyamatokra is, ugyanis az enzim fehérje szerkezetben található amino csoportok reagálhatnak az alkalmazott szubsztrátum redukáló végével, amelynek hatására megváltozhat az enzim szerkezete, és ez által elveszítheti aktivitását/stabilitását. BRUINS és munkatársai (2003b) Pyrococcus furiosus eredetű termostabil 
$\beta$-glikozidáz enzim esetébenazt tapasztalták, hogy $80{ }^{\circ} \mathrm{C}$ vagy annál magasabb hőmérsékleten az enzim cukor jelenlétében gyorsabban veszíti el aktivitását, mint anélküle. Ezt a hatást a Maillard reakciónak tulajdonították, amelyet a reakció közeg barnulása is megerősített. Később az enzim Eupergit $\mathrm{C}$ hordozóra történő kovalens rögzítésével próbálták a Maillard reakció gátlását, azonban sikertelenül (BRUINS et al., 2003b), talán azért, mert nem sikerült blokkolni az aktív aminocsoportokat.

Maitin és Rastall (2004) is végeztek hasonló kísérletet a Penicillium citrinum eredetü $\alpha$ mannozidáz enzim stabilitásának vizsgálatánál. Azt tapasztalták, hogy Maillard inhibitorok jelenlétében az enzim aktivitása kisebb mértékben csökken és azok alkalmazásával növelhető az oligoszacharid hozam (27 - 53\%-kal). 
DOI: 10.14267/phd.2015034 


\section{ANYAGOK ÉS MÓDSZEREK}

\subsection{Felhasznált anyagok}

\section{Enzimkészítmény}

- Aspergillus aculeatus eredetü Pectinex ultra SP-L enzimkészítmény (P2611, Sigma-Aldrich)

\section{Mikroorganizmusok}

- Escherichia coli BL21 (DE3) törzset alkalmaztam levánszukráz enzim termelésére, amelybe Braunschweigi Müszaki Egyetem Mikrobilógiai Tanszékének kutatócsoportja a Bacillus megateriumDSM 319 (DSMZ) eredetü levánszukráz enzimének génjét klónozta (BIEDENDIECK, 2007; HOMANNet al., 2007)

- Bifidobacterium longum Bb-46 (Christian-Hansen) törzset alkalmaztam Bifidobacterium eredetü enzimpreparátum előállítására

\section{Pufferek}

McIlvaine puffer (citrát-foszfát) puffer (MCILVAINe, 1921): $\quad$ pH 3,0 - 7,0

$0,1 \mathrm{M}$ citromsav oldat

$0,2 \mathrm{M} \mathrm{Na}_{2} \mathrm{HPO}_{4}$ oldat

Sörensen-féle foszfát puffer (SÖRENSEN, 1909): $\quad$ pH 6,6

$1 / 15 \mathrm{M} \mathrm{KH}_{2} \mathrm{PO}_{4}$ oldat

$1 / 15 \mathrm{M} \mathrm{Na}_{2} \mathrm{HPO}_{4}$ oldat

\section{Tápközegek}

Luria-Bertani (LB) tápoldat (SEZONOV et al., 2007):

- $10 \mathrm{~g} / \mathrm{l}$ pepton

- $5 \mathrm{~g} / \mathrm{l}$ élesztőkivonat

- $5 \mathrm{~g} / \mathrm{l} \mathrm{NaCl}$

TPY (Trypticase- Phyton- Yeast extract) tápoldat (SCARDOVI, 1981):

- $10 \mathrm{~g} / \mathrm{l}$ trypticase pepton

- $5 \mathrm{~g} / \mathrm{l}$ phyton pepton

- 5 g/l glükóz

- $2,5 \mathrm{~g} / 1$ élesztőkivonat

- $1 \mathrm{ml} / \mathrm{l}$ Tween80

- $0,5 \mathrm{~g} / \mathrm{l}$ cisztein- $\mathrm{HCl}$

- $2 \mathrm{~g} / \mathrm{l} \mathrm{K}_{2} \mathrm{HPO}_{4}$

- $0,5 \mathrm{~g} / \mathrm{l} \mathrm{MgCl} 2 * 6 \mathrm{H}_{2} \mathrm{O}$

- $0,25 \mathrm{~g} / \mathrm{ZnSO}_{4} * \mathrm{H}_{2} \mathrm{O}$

- $0,15 \mathrm{~g} / \mathrm{l} \mathrm{CaCl} 2$

- $0,03 \mathrm{~g} / \mathrm{FeCl}_{2}$

A tápközegek sterilezése $121{ }^{\circ} \mathrm{C}$-on, 15 percig történt. 


\section{Szénhidrátok}

A biokonverzióban alkalmazott szubsztrátumok analitikai minőségüek és különböző cégektől szereztem be (8. táblázat).

\section{8. táblázat: Felhasznált szénhidrátok}

\begin{tabular}{|c|c|c|}
\hline & Szénhidrát & Forgalmazó \\
\hline \multirow{20}{*}{ 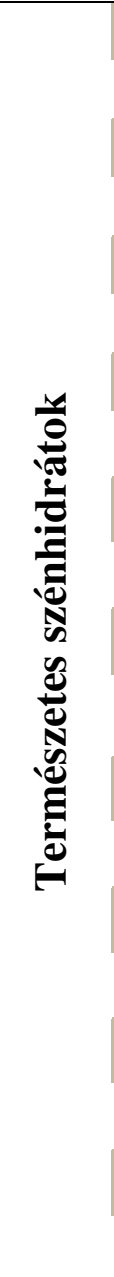 } & L-arabinóz & Reanal \\
\hline & D-fruktóz & Reanal \\
\hline & D-glükóz & Reanal \\
\hline & D-mannóz & Fluka \\
\hline & L-ramnóz & Reanal \\
\hline & L-szorbóz & Reanal \\
\hline & D-xilóz & Reanal \\
\hline & cellobióz: O- $\beta$-D-glükozil-(1-4)-D-glükóz & Fluka \\
\hline & laktóz: O- $\beta$-D-galaktozil-(1-4)-D-glükóz & Fluka \\
\hline & laktulóz: O- $\beta$-D-galaktozil-(1-4)-D-fruktóz & Sigma-Aldrich \\
\hline & maltotrióz: O- $\alpha$-D-glükozil-(1-4)- $\alpha$-D-glükozil-(1-4)-D-glükóz & Sigma-Aldrich \\
\hline & $\begin{array}{l}\text { maltotetraóz: O- } \alpha \text {-D-glükozil-(1-4)- } \alpha \text {-D-glükozil-(1-4)- } \alpha \text {-D- } \\
\text { glükozil -(1-4)-D-glükóz }\end{array}$ & Sigma-Aldrich \\
\hline & maltóz: O- $\alpha$-D-glükozil-(1-4)-D-glükóz & Sigma-Aldrich \\
\hline & maltulóz: O- $\alpha$-D-glükozil-(1-4)-D-fruktóz & Sigma-Aldrich \\
\hline & melibióz: O- $\alpha$-D-galaktozil-(1-6)-D-glükóz & Fluka \\
\hline & palatinóz: O- $\alpha$-D-glükozil-(1-6)-D-fruktóz & Sigma-Aldrich \\
\hline & raffinóz: O- $\alpha$-D-galaktozil-(1-6)-D-glükozil-(1-2)-D-fruktóz & Reanal \\
\hline & szacharóz: O- $\alpha$-D-glükozil-(1-2)- $\beta$-D-fruktóz & VWR \\
\hline & trehalóz: O- $\alpha$-D-glükozil-(1-1)- $\alpha$-D-glükóz & Sigma-Aldrich \\
\hline & turanóz: O- $\alpha$-D-glükozil-(1-3)-D-fruktóz & Sigma-Aldrich \\
\hline \multirow{5}{*}{ 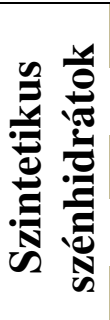 } & p-nitrofenil- $\alpha$-D-glükopiranozid & Sigma-Aldrich \\
\hline & p-nitrofenil- $\beta$-D-glükopiranozid & Sigma-Aldrich \\
\hline & p-nitrofenil- $\alpha$-D-galaktopiranozid & Sigma-Aldrich \\
\hline & p-nitrofenil- $\beta$-D-galaktopiranozid & VWR \\
\hline & p-nitrofenil- $\alpha$-D-mannopiranozid & Sigma-Aldrich \\
\hline
\end{tabular}

\section{Maillard inhibitorok}

- o-fenilén-diamin-dihidroklorid (OPD)

- szemikarbazid-hidroklorid (SMC)

- aminoguanidin-hidroklorid (AG)

A Maillard inhibitorok a Sigma-Aldrich Kft.-től származnak. 


\subsection{Mikrobiológiai eljárások}

\subsubsection{Bacillus megaterium eredetü levánszukráz elöállítása}

\section{Inokulum tenyészet készítése}

Először beoltottam az $50 \mu \mathrm{l}$ glicerines oldatban tárolt E. coli BL21 (DE3) sejteket $50 \mathrm{ml}, 0,5 \mathrm{mM}$ ampicillint tartalmazó LB tápközegbe. Ezt követően a sejteket $37{ }^{\circ} \mathrm{C}$-on, $160 \mathrm{rpm}$ fordulatszámon 24 óráig inkubáltam.

\section{Enzimfermentáció}

Az elkészített inokulumot hozzáadtam $500 \mathrm{ml}, 0,5 \mathrm{mM}$ ampicillint tartalmazó LB tápleveshez, majd 3 órán keresztül $\left(37{ }^{\circ} \mathrm{C}\right.$-on, $120 \mathrm{rpm}$ fordulatszámon) inkubáltam. Ezt követőena fehérjeexpresszió indukálása céljából hozzáadtam $0,5 \quad \mathrm{mM}$ IPTG-t (izopropil $\beta$-Dtiogalaktozidot) a tenyészethez. A hőmérsékletet ezután lecsökkentettem $30{ }^{\circ} \mathrm{C}$-ra, és tovább inkubáltam rázatás mellett 21 órán át.

\section{Levánszukráz enzim kinyerése $E$. coli BL21 (DE3) sejtekből}

A sejteket centrifugáltam $\left(10.000 \mathrm{rpm}, 4{ }^{\circ} \mathrm{C} 30\right.$ percig), majd a pelletet $30 \mathrm{ml}$ Sörensen-féle pufferrel $(50 \mathrm{mM}, \mathrm{pH}$ 6,6) mostam. Ezután újra centrifugáltam, és a pelletet 6,25 ml Sörensen pufferben szuszpendáltam. A sejtfeltárást ultrahanggal végeztem (Sonoplus, Bandelinelectronics sonotrode MS72), amelynek körülményei: 97\% erősség, 50\% idő, 5 perc. A sejtszuszpenziót feltárás közben jégben tároltam a hődenaturáció elkerülése végett. A feltárás után centrifugáltam a preparátumot $\left(8000 \mathrm{rpm}, 60\right.$ perc, $\left.4{ }^{\circ} \mathrm{C}\right)$. A kapott felülúszó tartalmazta a rekombináns levánszukráz (Ftf) enzimet. Enzim tárolása -20 C-on történt.

A levánszukráz enzim előállítása a Braunschweigi Műszaki Egyetem Müszaki Kémia Tanszékén került megvalósításra.

\subsubsection{Bifidobacterium longum eredetü enzimpreparátum elöállítása Inokulum tenyészet készítése}

A TPY tápközegben fenntartott törzs 24 órás tenyészetéből $1 \mathrm{ml}$-t oltottam be $20 \mathrm{ml}$ TPY tápközegbe, majd $37{ }^{\circ} \mathrm{C}$-on 24 óráig inkubáltam, anaerob körülmények között.

\section{Enzimfermentáció}

A preparátum előállításához $600 \mathrm{ml}$ térfogatú TPY tápközeget alkalmaztam, amelyben (az enzim indukálása céjából) a glükózt laktóz szénforrással helyettesítettem. A fermentáció indításához 1 tf \%-os 24 órás inokulum tenyészetet használtam. A fermentáció időtartama 21 óra volt.

\section{Enzimkinyerés Bifidobacterium longum Bb-46 sejtekből}

A sejteket centrifugáltam $\left(10000 \mathrm{rpm}, 4{ }^{\circ} \mathrm{C}, 10\right.$ perc $)$ és a pelletet kétszer mostam $125 \mathrm{ml}$ McIlvaine pufferrel ( $\mathrm{pH}$ 6,6). Ezt követően újra centrifugáltam a sejteket, majd $15 \mathrm{ml}$ puffer 
hozzáadásával szuszpendáltam. A sejtek feltárását French Press nagynyomású homogenizátorral végeztem (800 psi nyomással). A kapott preparátumot $-20^{\circ} \mathrm{C}$-on tároltam.

\subsection{Biokonverziós eljárások}

\subsubsection{Pectinex ultra enzimkészítménnyel}

\section{Szintézis vizsgálat monoszubsztrátumokon}

Az oligoszacharid szintézist $1 \mathrm{ml}$ térfogatú, 30 g/100ml szubsztrátum koncentrációjú (arabinóz, fruktóz, glükóz, mannóz, ramnóz, szorbóz, xilóz, cellobióz, laktóz, maltóz, maltulóz, melibióz, palatinóz, trehalóz, turanóz) oldatban vizsgáltam, a reakcióhoz szükséges hőmérsékletet $\left(60^{\circ} \mathrm{C}\right)$ vízfürdő segítségével biztosítottam, a pH 5,5-t McIlvaine pufferrel állítottam be. Az enzimes reakciót $0,15 \mathrm{mg}$ fehérje/g szénhidrát $(13 \mu \mathrm{l})$ enzimmennyiséggel indítottam. A 96 órás biokonverzió során napi mintavételezés történt. A mintákban 10 perces forralással inaktiváltam az enzimet. A biokonverzió nyomon követésére HPLC-RID technikát használtam.

\section{- Szubsztrátum hatása}

A szubsztrátum (mannóz) koncentráció hatását 10 - 80 g/100ml tartományban vizsgáltam pH 6,5 mellett. A további paramétereket nem változtattam.

- $\mathrm{pH}$ és hömérséklet hatása

Mindkét paraméter vizsgálatához $60 \mathrm{~g} / 100 \mathrm{ml}$ szubsztrátum koncentrációt alkalmaztam. A pH hatását pH 3,0 - 7,0 tartományban (melyet McIlvaine puffer felhasználásával),a hőmérséklet hatását $50-80{ }^{\circ} \mathrm{C}$ tartományban vizsgáltam. A hőmérséklet hatásának tanulmányozását pH 5,0 értéken hajtottam végre.

- Enzimmennyiség hatása

Az optimális enzimmennyiség megállapításához 60 g/100ml szubsztrátum koncentrációt, pH 5,0 (McIlvaine pufferrel) és $70{ }^{\circ} \mathrm{C}$ paramétereket alkalmaztam. Az enzimmennyiséget 0,8 - 3,9 mg fehérje/g szénhidrát $(40$ - $200 \mu \mathrm{l})$ tartományban változtattam.

- Maillard-reakció hatása

A Maillard inhibitorok hatását 60 g/100ml szubsztrátum koncentráció alkalmazásával vizsgáltam, pH 5,0-n (Sörensen-féle foszfát pufferrel) és $70^{\circ} \mathrm{C}$-on. A reakció indítása 3,1 mg fehérje/g szubsztrátum enzimmennyiséggel történt. A Maillard inhibitor vegyületek hatását $15 \mathrm{mM}$ koncentrációban tanulmányoztam.

A paraméterek hatását minden esetben 96. órás biokonverzió esetében tanulmányoztam, melyhez HPLC-RID technikát alkalmaztam. Egyes esetekben a szénhidrát termékek relatív oligoszacharid hozamát hasonlítottam össze a következő képlet szerint:

$$
\text { Relatív termék hozam }=\frac{\text { Termékek kromatogram területe (96.óra) }}{\text { Termékek maximális kromatogram területe }(96.0 ́ r a)} * 100 \text { [\%] }
$$




\section{Reverz hidrolízis vizsgálata biszubsztrátumokon}

A termékszintézist a következő paraméterek mellett valósítottam meg: 60 g/100ml szubszrátum koncentráció; pH 5,0 (McIlvaine puffer); $70{ }^{\circ} \mathrm{C}$. A reakciót 3,9 mg fehérje/g szubsztrátum enzimmennyiséggel indítottam. A biokonverziót 96 óráig tanulmányoztam. A reakció leállítása céljából 10 perces forralást alkalmaztam. Az egyes monoszacharid kombinációk összeállítása során 2:1 arányt (mannóz:arabinóz/glükóz/fruktóz/szorbóz/xilóz) használtam. A szénhidrát összetételt HPLC-RID és TLC módszerrel követtem nyomon.

\section{Transzglikoziláció vizsgálata biszubsztrátumokon}

Az oligoszacharid szintézist $5 \mathrm{ml}$ térfogatú $10 \mathrm{~g} / 100 \mathrm{ml}$ koncentrációjú szubsztrátum oldatban vizsgáltam, a reakcióhoz szükséges hőmérsékletet $\left(60^{\circ} \mathrm{C}\right)$ vízfürdő segítségével biztosítottam, a pH 5,5-t McIlvaine pufferel állítottam be. A biszubsztrátumok összeállításánál a szacharózt és a laktózt kombináltam különböző szénhidrátokkal (szacharóz, laktóz, maltóz, fruktóz, galaktóz, glükóz, mannóz, xilóz) 1:1 arányban. A reakciót $0,16 \mathrm{mg}$ fehérje/g szénhidrát enzimmennyiséggel indítottam. A biokonverzió során bizonyos időközönként mintát vettem, és 10 perces forralással inaktiváltam az enzimet. A szénhidrát összetételt HPLC-RID és TLC technikával vizsgáltam. A szubsztrátum arány hatását 1:9 - 9:1 arányoknál, az összes szénhidrát koncentráció hatását 10 - 70 g/100 ml tartományban vizsgáltam.

\subsubsection{Bacillus megaterium eredetü levánszukráz enzimmel}

Elvégeztem a biokonverziót a Bacillus megaterium eredetü levánszukráz enzimmel is biszubsztrátum rendszerben. A megvalósításhoz a szacharózt 2 másik diszachariddal; laktózzal és maltózzal; kombináltam 2:1 és 1:2 arányban. Kétféle szubsztrátum koncentrációt $30,75 \mathrm{~g} / 100 \mathrm{ml}$ és $61,5 \mathrm{~g} / 100 \mathrm{ml}$ alkalmaztam. Kontrol vizsgálatot is végeztem, melyben a szacharózt használtam egyedüli kiindulási anyagként, 6,84 és 17,1g/100ml koncentrációban. A vizsgálatokat az enzim optimum paraméterei mellett, pH 6,6-on (Sörensen-féle foszfát puffer) és $37{ }^{\circ} \mathrm{C}$-on végeztem. A bemért enzim mennyiség $5 \mathrm{U} / \mathrm{ml}$ volt. A biokonverziót 4 óráig vizsgáltam. A szénhidrát összetétel alakulását HPAEC-PAD módszerrel tanulmányoztam.

A Bacillus megaterium eredetü levánszukráz enzimmel végrehajtott biokonverziós vizsgálatokat a Braunschweigi Müszaki Egyetem Müszaki Kémia Tanszékén végeztem.

\subsubsection{Bifidobacterium longum eredetü enzimpreparátummal}

\section{Transzglikoziláció vizsgálata monoszubsztrátumokon}

Bifidobacterium longum Bb-46 eredetü fehérjével végzett biokonverziós kísérletet, $1 \mathrm{ml}$ térfogatban, $30 \mathrm{~g} / 100 \mathrm{ml}$ szénhidrát koncentráció, $40{ }^{\circ} \mathrm{C}$ és $\mathrm{pH}$ 6,6 paraméterek alkalmazásával hajtottam végre. A biokonverziót $1,08 \mathrm{mg}$ fehérje/g szénhidrát $(100 \mu \mathrm{l})$ enzimmennyiséggel 
indítottam és 96 óráig tanulmányoztam. A különböző időpontokban vett minták szénhidrát összetételét HPLC-RID módszerrel vizsgáltam.

\section{Transzglikoziláció vizsgálata biszubsztrátumokon}

Biszubsztrátum rendszereknél a monoszubsztrátumok esetében alkalmazott paramétereket használtam. Biszubsztrátumként laktóz:maltóz, laktóz:szacharóz, laktulóz:maltóz és laktulóz:szacharóz szénhidrát keverékeket alkalmaztam 1:1 arányban. A különböző időpontokban vett minták szénhidrát összetételét TLC és HPLC-RID módszerrel vizsgáltam.

A szacharóz:laktóz és maltóz:laktóz kombinációk esetén a szubsztrátum koncentráció és a szubsztrátum arány együttes hatásának vizsgálatát a következő táblázatban látható séma szerint valósítottam meg (9. táblázat).

9. táblázat: A Bifidobacterium longum eredetü preparátum biszubsztrátum rendszerekben történő vizsgálatánál alkalmazott szubsztrátum kombinációk

\begin{tabular}{|c|c|c|c|c|}
\hline & $\begin{array}{c}\text { Szubsztrátum } \\
\text { koncentráció }(\mathrm{g} / 100 \mathrm{ml})\end{array}$ & $\begin{array}{c}\text { Arányok } \\
\left(\mathbf{S z}: \mathbf{L} / \mathbf{M}: L^{*}\right)\end{array}$ & $\begin{array}{c}\text { Szacharóz/Maltóz } \\
(\mathrm{g} / 100 \mathrm{ml})\end{array}$ & $\begin{array}{c}\text { Laktóz } \\
(\mathrm{g} / 100 \mathrm{ml})\end{array}$ \\
\hline 1 & \multirow{5}{*}{10} & $0: 100$ & 0 & 10 \\
\hline 2 & & $25: 75$ & 2,5 & 7,5 \\
\hline 3 & & $50: 50$ & 5 & 5 \\
\hline 4 & & $75: 25$ & 7,5 & 2,5 \\
\hline 5 & & 100:0 & 10 & 0 \\
\hline 6 & \multirow{5}{*}{20} & $0: 100$ & 0 & 20 \\
\hline 7 & & $25: 75$ & 5 & 15 \\
\hline 8 & & $50: 50$ & 10 & 10 \\
\hline 9 & & $75: 25$ & 15 & 5 \\
\hline 10 & & 100:0 & 20 & 0 \\
\hline 11 & \multirow{5}{*}{30} & $0: 100$ & 0 & 30 \\
\hline 12 & & $25: 75$ & 7,5 & 22,5 \\
\hline 13 & & $50: 50$ & 15 & 15 \\
\hline 14 & & $3: 25$ & 22,5 & 7,5 \\
\hline 15 & & 100:0 & 30 & 0 \\
\hline 16 & \multirow{3}{*}{40} & $50: 50$ & 20 & 20 \\
\hline 17 & & $75: 25$ & 30 & 10 \\
\hline 18 & & 100:0 & 40 & 0 \\
\hline
\end{tabular}

Sz: szacharóz, L:laktóz, M: maltóz

\subsection{Analitikai módszerek}

\subsubsection{Enzimaktivitás meghatározása}

\subsubsection{A Pectinex utra és a Bifidobacterium longum eredetü preparátum aktivitásainak meghatározása}

A Pectinex ultra és a Bifidobacterium longum Bb-46 eredetü enzimpreparátum $\beta$-galaktozidáz, $\alpha$-galaktozidáz, $\alpha$-glükozidáz, $\beta$-glükozidáz aktivitásának meghatározásához különböző 15 mM-os kromoforoszubsztrátum (p-nitrofenil- $\beta$-D-galaktopiranozid, p-nitrofenil- $\alpha$-Dgalaktopiranozid, p-nitrofenil- $\alpha$-D-glükopiranozid, p-nitrofenil- $\beta$-D-glükopiranozid, p-nitrofenil$\alpha$-D-mannopiranozid) oldatokat használtam fel. A Pectinex ultra enzimkészítmény aktivitásainak 
meghatározásához pH 6,0 (McIlvaine puffer) és $60^{\circ} \mathrm{C}$, a Bifidobacterium longum Bb-46 eredetü preparátum aktivitásainak meghatározásához pH 6,6 (McIlvaine puffer) és $37{ }^{\circ} \mathrm{C}$ környezeti paramétereket alkalmaztam és a következő táblázatban látható összemérést végeztem el (10. táblázat).

$\mathrm{Az}$ enzimoldat hozzáadása előtt a reakcióelegyeket 5 percig inkubáltam, majd $0,2 \mathrm{ml}$ megfelelően hígított preparátummal indítottam az 5 perces reakciót. A reakció leállítása céljából $5 \mathrm{ml} 0,1 \mathrm{M} \mathrm{Na} \mathrm{CO}_{3}$ oldatot mértem a reakcióelegyhez. Spektrofotométerrel $405 \mathrm{~nm}$-en megmértem az oldat abszorbanciáját. Az aktivitást a felszabaduló p-nitrofenol mennyisége alapján határoztam meg. A felszabadult p-nitrofenol mennyiségének meghatározásához előzőleg standard sort készítettem 0,04 - 0,4 mM koncentráció tartományban (1 ml térfogatban). A kalibrációhoz készített megfelelő koncentrációjú hígítási tagokra szintén rámértem $5 \mathrm{ml}$ leállító oldatot.

Az aktivitás számításához a következő képeletet alkalmaztam:

$$
\text { Aktivitás }=\frac{(A M-A E V-A S V) * h * V r}{V m * t * a}(\mathrm{U} / \mathrm{ml})
$$

$\begin{array}{ll}A M: & \text { reakcióelegy abszorbanciája } \\ A E V: & \text { enzimvak oldat abszorbanciája } \\ A S V: & \text { szubsztrátumvak abszorbanciája } \\ h: & \text { enzimoldat hígítása }\end{array}$

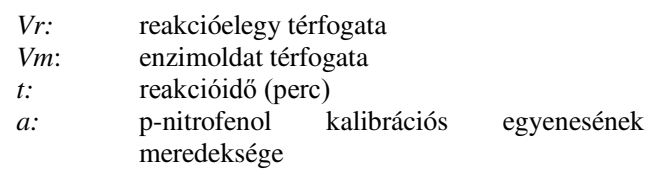

Egy enzimaktivitás egység az az enzimmennyiség, amely percenként $1 \mu$ mol p-nitrofenolt szabadít fel adott reakciókörülmények között.

A Pectinex ultra és Bifidobacterium longum $\beta$-fruktozidáz aktivitásának meghatározása szacharóz szubsztrátumon történt. Az aktivitásméréshez használt összemérések és a reakció körülményei megegyeztek a kromoforoszubsztrátumok esetében használtakkal. A $\beta$-fruktozidáz aktivitást a felszabaduló redukáló cukor mennyiségéből számoltam. A redukáló cukor tartalom méréséhez BCA módszert (REZESSY-SZABó et al., 2007) alkalmaztam, melyhez előzőleg glükóz standard sort készítettem (0,5 - 1 mM koncentráció tartományban).

10. táblázat: A Pectinex ultra és Bifidobacterium longum Bb-46 eredetü enzimkészítmény aktivitásainak meghatározásához használt összemérés

\begin{tabular}{|c|cccc|}
\hline & $\begin{array}{c}\text { Desztillált víz } \\
(\mathbf{m l})\end{array}$ & $\begin{array}{c}\text { Puffer } \\
(\mathbf{m l})\end{array}$ & $\begin{array}{c}\text { Szubsztrátum oldat } \\
(\mathbf{m l})\end{array}$ & $\begin{array}{c}\text { Enzim oldat } \\
(\mathbf{m l})\end{array}$ \\
\hline Müszervak & 0,7 & 0,3 & - & - \\
Szubsztrátum vak & 0,2 & 0,3 & 0,5 & - \\
Enzim vak & 0,5 & 0,3 & - & 0,2 \\
Reakcióelegy & - & 0,3 & 0,5 & 0,2 \\
\hline
\end{tabular}


Egy $\beta$-fruktozidáz aktivitás egység az az enzimmennyiség, amely percenként $1 \mu$ mol redukáló cukrot szabadít fel adott reakciókörülmények között.

Az enzimkészítmények aktivitás értékei a következő táblázatban láthatók (11. táblázat).

\section{1. táblázat: A Pectinex ultra és a Bifidobacterium longum Bb-46 eredetü preparátum hidroláz aktivitásai}

\begin{tabular}{|c|cc|}
\hline & $\begin{array}{c}\text { Pectinex ultra } \\
(\mathbf{U} / \mathbf{m l})\end{array}$ & $\begin{array}{c}\text { Bifidobacterium longum } \\
\text { eredetú preparátum }(\mathbf{U} / \mathbf{m l})\end{array}$ \\
\hline$\alpha$-glükozidáz & 1,5 & 2,0 \\
\hline$\beta$-glükozidáz & 1,4 & 0,3 \\
$\alpha$-galaktozidáz & 10,4 & 1,2 \\
$\beta$-galaktozidáz & 35,8 & 0,4 \\
$\alpha$-mannozidáz & 1,0 & 0 \\
$\beta$-fruktozidáz & 484,8 & 11,5 \\
\hline (paraméterek: $\quad$ Pectinex ultra enzimkészítmény esetén $\mathrm{pH} 6,0,60^{\circ} \mathrm{C}, 7,5 \mathrm{mM}$ szubsztrátum \\
Bifidobacterium longum Bb-46 esetén $\mathrm{pH} 6,5,37^{\circ} \mathrm{C}, 7,5 \mathrm{mM}$ szusbsztrátum)
\end{tabular}

\subsubsection{Bacillus megaterium eredetű levánszukráz akvitásának meghatározása}

A Bacillus megaterium eredetű levánszukráz aktivitásának meghatározását $0,5 \mathrm{M}$ szacharóz szubsztrátumon, $37{ }^{\circ} \mathrm{C}$ és $\mathrm{pH}$ 6,6 körülmények között végeztem. A következő összemérést alkalmaztam: $856 \mu \mathrm{l}$ szacharóz oldat $(40 \mathrm{~g} / 100 \mathrm{ml})+40 \mu \mathrm{l}$ enzimoldat $+1104 \mu \mathrm{l}$ puffer (Sörensen-féle foszfát puffer). A reakciót 30 percig követtem nyomon. A 0., 5., 10., 20. és 30. percben vettem mintát, amelyeket 10 percig forraltam a reakció leállítása céljából. Meghatároztam a minták redukáló cukor tartalmát DNS módszerrel (SUMER \& HowELL, 1935), amelyhez előzőleg glükóz standard sort készítettem 0,3 - 9 mM koncentráció tartományban. A kapott redukáló cukor tartalom értékeket ábrázoltam az idő függvényében és a pontokra egyenest illesztettem. Az egyenes meredekségét szorozva az enzim hígulásával (50x) megkaptam az aktivitás értéket, ami 339,3 U/ml volt.

Egy levánszukráz aktivitás egység az az enzimmennyiség, amely percenként $1 \mu$ mol redukáló cukrot szabadít fel adott reakciókörülmények között.

A levánszukráz aktivitásának meghatározását a Braunschweigi Müszaki Egyetem Műszaki Kémiai Tanszékén végeztem. 


\subsubsection{HPLC technikák}

\section{Surveyor HPLC-RID készülék:}

$\underline{\text { Részei }}$

- Pumpa: Surveyor négy csatornás pumpa

- Mintaadagoló: Surveyor automata mintaadagoló

- Detektor: Surveyor RI detektor

- Elválasztó oszlop: Agilent HiPlex H vagyAminex HPX-87H

Futtatás paraméterei

- Futtatási idő: 25 perc

- Eluens: 0,005n $\mathrm{H}_{2} \mathrm{SO}_{4}$

- Áramlási sebesség: 0,6 ml/perc

- Minta előkészítése: centrifugálás és 10-szeres hígítás

Mért szénhidrátok retenciós sorrendje:

maltotetraóz < maltotrióz, raffinóz < cellobióz, laktóz, laktulóz, maltóz, maltulóz, melibióz, palatinóz, szacharóz, turanóz, trehalóz < glükóz< szorbóz < arabinóz, fruktóz, galaktóz, mannóz, ramnóz, xilóz

\section{Dionex 3000 HPAEC-PAD készülék}

$\underline{\text { Részei }}$

- pumpa: Gradient Pump, Modell GPM-2, Fa. Dionex

- előoszlop: CarboPac PA1.4*50 mm, Fa. Dionex

- elválasztó oszlop: CarboPac PA1.4*250 mm, Fa. Dionex,

- detektor: PAD (Pulsed Amperometric Detector), Modell PAD-2, Fa. Dionex

- mintaadagoló: Series 200, Tefzel Rheodyne- Ventil, Fa. Perkin-Elmer

Futtatás paraméterei

- Futtatási idő: 30 perc

- Eluensek: A eluens: $100 \mathrm{mM}$ 50\% NaOH, B eluens: $100 \mathrm{mM} 50 \% \mathrm{NaOH}+$ 1 M Na-acetát

- Áramlási sebesség: $1 \mathrm{ml} /$ perc

- Oszlop regenerálása: $1 \mathrm{M} \mathrm{NaOH}$ oldattal

Mért szénhidrátok retenciós sorrendje:

fruktóz < glükóz <laktóz <szacharóz <maltóz

\subsubsection{TLC technika}

A szénhidrátok minőségi kimutatását vékonyréteg elválasztással is elvégeztem. Állófázisként TLC “szilika gél 60”-nal fedett alumínium lemezeket $(20 * 20 \mathrm{~cm})$ használtam (VWR). Mozgófázisként kloroform/ecetsav/víz 30/35/5 arányú elegyét alkalmaztam (UGRINOVITS, 1980). Az elöhívó a következő összetevőkből állt: 0,3 g/100 ml N-(1-naftil)-etilén-diamin-dihidroklorid, 5 (V/V)\% $\mathrm{H}_{2} \mathrm{SO}_{4}, 94,7$ (V/V)\% metanol (BounIAS, 1980). Az elválasztáshoz a megfelelően hígított (0,1-0,5 g/100 ml koncentrációjú) mintákból 1 $\mu$ l-nyi mennyiséget csepegtettem a TLC lemezre. A futtatási idő 2 óra volt. 


\subsubsection{MALDI-TOF-MS módszer}

A szénhidrát termék minták MALDI-TOF MS módszerrel történő vizsgálata a Debreceni Egyetem Szervetlen és Analitikai Kémiai Tanszékén került megvalósításra, GYÉMÁNT és munkatársai (2001) által leírt módszer szerint:

- Bruker Biflex III tömegspektrométer

- mátrix: 2,5-dihidroxi-benzoesav vagy 2,3,6-trihidroxi-acetofenon

- minta molekulák gáz fázisba juttatása és ionizálása nitrogén lézer, 3 ns impulzusidő alkalmazásával

- többszöri, általában 100 impulzus alkalmazása $19 \mathrm{kV}$ gyorsító és $20 \mathrm{kV}$ reflektron feszültség mellett.

- a vegyületek azonosítása az $[\mathrm{M}+\mathrm{Na}]^{+}$és $[\mathrm{M}+\mathrm{K}]^{+}$ionok csúcsai alapján történt

\subsubsection{Fehérjetartalom meghatározás}

Az enzimpreparátumok fehérjetartalmának meghatározásához a festékmegkötődésen alapuló Bradford módszert (BRADFORD, 1976) alkalmaztam. A reakció során a fehérje és a színező anyag (Coomassie Brilliant Blue G250) kék színű komplexet hoz létre, amely detektálható $595 \mathrm{~nm}$ tartományban spektrofotométer segítségével.

A meghatározáshoz a Bio-Rad cég által forgalmazott színező reagenst használtam. A kalibrációs egyenes felvételéhez hígítási sort készítettem $0,1-0,5 \mathrm{mg} / \mathrm{ml}$ koncentráció tartományban BSA (Bovine Serum Albumin) törzsoldat segítségével. A mérést mikrotiter lemezben hajtottam végre a gyártó által megadott útmutató alapján. Az abszorbanciákat mikrotiter lemezolvasó segítségével $595 \mathrm{~nm}$-en határoztam meg.A Pectinex ultra fehérjetartalma 11,52 mg/ml, a Bifidobacterium longum eredetű preparátum fehérje tartalma $3,22 \mathrm{mg} / \mathrm{ml}$ volt.

\subsection{Szénhidrát elválasztási módszer}

A termék szénhidrát elválasztásaBio-Gel P2 töltetü oszlopon történt.

- Oszlop mérete: $78 * 1,8 \mathrm{~cm}$

- Regenerálás: 1 1,3\%-os $\mathrm{H}_{2} \mathrm{O}_{2}$ oldattal, majd mosás 21 desztillált vízzel

- Eluens: desztillált víz

- 1 g szénhidrát felvitele az oszlopra

- Áramlási sebesség: 0,75 ml/perc

- Frakciók térfogata: $2 \mathrm{ml}$

- Tisztítás nyomonkövetése: HPLC-RID és TLC módszerrel 


\subsection{Statisztikai módszerek}

A Bifidobacterium longum $\mathrm{Bb}-46$ eredetü enzimpreparátummal végzett biokonverzió kísérleteim eredményei értékelése során, különböző modelleket hoztam létre. Mivel két független változó egyidejű hatását vizsgáltam, így háromdimenziós modellekhez jutottam. Az adatokra a modellillesztést a legkisebb négyzetek elvén alapuló módszerrel (Levenberg-Marquardt algoritmus) végeztem. Az értékelés során több modell illeszkedését vizsgáltam, mint lineáris, logaritmikus, exponenciális, polinomiális, valamint ezek kombinációját (többszörös lineáris, stb.) A legjobban illeszkedő modellt a kapott determinációs koefficiens $\left(\mathrm{R}^{2}\right)$ értéke alapján választottam ki.

A kiválasztott modelleket ezt követően tovább vizsgáltam abból a szempontból, hogy a modell együtthatói releváns információ tartalommal rendelkeznek-e, vagy esetleg elhagyhatóak a modellből (regressziós diagnosztika). Az együtthatók tesztelése során t-próbát alkalmaztam, amely a függő változó egy-egy magyarázó változótól való tesztelésére szolgál. Ha a t-próba eredménye nagyobb volt, mint a kritikus t-érték, akkor az együttható elhagyható a modellből. A kritikus t-értékeket a szabadsági fok alapján a Student-féle t-táblázatból olvastam ki. A t-próba eredménye mellett a p-értéket is jelöltem, ami azt mutatja, hogy mekkora az első fajú hiba valószínüsége, ha elfogadjuk a nullhipotézist, tehát hogy az együttható nincs hatással a függő változóra (REICZIGEL et al., 2010). A hibák normális eloszlását és függetlenségét minden esetben vizsgáltam, viszont a terjedelmi korlátok miatt nem jelöltem. A statisztikai vizsgálatokat a STATISTICA 9 (StatSoft) programcsomag segítségével végeztem. 
DOI: 10.14267/phd.2015034 


\section{KÍSÉRLETI EREDMÉNYEK ÉS ÉRTÉKELÉSÜK}

\subsection{Oligoszacharid szintézis monoszubsztrátumokon}

\subsubsection{Transzglikoziláció Pectinex ultra enzimkészitménnyel}

Az utóbbi időben számos publikáció jelent meg arról, hogy a Pectinex ultra a specifikációban szereplő enzimeken kívül egyéb olyan enzimeket tartalmaz (fruktoziltranszferáz és $\beta$-galaktozidáz) mellyel különböző oligoszacharidok szintetizálhatók (GHAZI et al., 2007; CARDELle-CoBAS et al., 2008). Ezen ismeretek adtak alapot annak, hogy az enzimkészítmény további szennyező aktivitásait feltérképezzem oligoszacharid szintézise céljából. Ennek megvalósítására biokonverziót indítottam különböző szubsztrátumokon, melyhez a készítményt tisztítás nélkül alkalmaztam. A transzglikozilációt különböző összetételü és kötésü diszacharidokon, a reverz hidrolízist különböző monoszacharidokon tanulmányoztam, pH 5,5, $60{ }^{\circ} \mathrm{C}, 30 \mathrm{~g} / 100 \mathrm{ml}$ paraméterek alkalmazásával.

\subsubsection{Glükozil-glükózok}

A Pectinex ultra transzglükozilációs képességét mind $\beta$-, mind $\alpha$ - kötésü glükobióz szénhidráton tanulmányoztam. A biokonverziót HPLC-RID technikával követtem nyomon. Eredményeimet a 12. táblázat mutatja.

12. táblázat: Szénhidrát összetétel változása a Pectinex ultra által katalizált transzglikozilációs reakciók során, glükobióz szubsztrátumokon

\begin{tabular}{|c|c|c|c|c|}
\hline Szubsztrátum & $\begin{array}{c}\text { Termék } \\
\text { retenciós ideje } \\
\text { (perc) }\end{array}$ & $\begin{array}{c}\text { Maximális } \\
\text { termék terület } \\
\left(\mu \mathrm{RIU}{ }^{*} \text { perc }\right)\end{array}$ & $\begin{array}{c}\text { Glükóz } \\
\text { koncentráció } \\
\text { növekedés } \\
(\mathrm{g} / \mathbf{1 0 0 m l}) \\
\end{array}$ & $\begin{array}{c}\text { Szubsztrátum } \\
\text { koncentráció } \\
\text { csökkenés } \\
(\mathrm{g} / 100 \mathrm{ml})\end{array}$ \\
\hline cellobióz & 6,786 & 2055271 & 1,3 & 3,1 \\
\hline maltóz & 6,81 & 1083377 & 26,8 & 27,6 \\
\hline trehalóz & 6,83 & 120250 & 0,8 & 0,93 \\
\hline
\end{tabular}

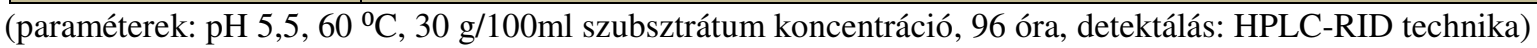

\section{Cellobióz}

Tekintve, hogy az enzimkészítmény specifikációja alapján tartalmaz cellulázt, illetve kimutattam $\beta$-glükozidáz aktivitását biokonverziós kísérletet végeztem cellobióz szubsztrátumon. A cellobióz egy $\beta(1-4)$ kötésủ glükóz diszacharid, amelyet már számos kutató alkalmazott szubsztrátumként oligoszacharid előállítására (YAN \& LIAU, 1998; BRUINS et al., 2003a). Az általam vizsgált enzimkészítmény esetében is kimutatható volt e szubsztrátumon oligoszacharid szintézisglükóz képződése mellett. 
A biokonverzió 96. órájában vett minta HPLC-RID vizsgálatánál a cellobióztól és glükóztól eltérő retenciós idejű (6,782 perc) terméket mutattam ki. Ez a retenció közel azonos a korábban vizsgált triszacharid standard-ek (maltotrióz, raffinóz) retenciós idejével, így feltételezhető, hogy a keletkezett termék trimer. Az egyes szénhidrátok mennyiségi változása alapján megfigyelhető, hogy míg a cellobióz koncentrációja csökken, a glükóz mennyisége növekszik. A szubsztrátum koncentrációjának csökkenése nagyobb volt, mind a glükóz koncentrációjának csökkenése, ez is alátámasztja új termék keletkezését.

A lejátszódó hidrolízis és transzfer reakció is igazolja a Pectinex ultra celluláz tartalmát. A készítmény oligoszacharid szintetizáló képességét cellobiózon azonban még nem bizonyították. Más, gomba eredetű celluláz enzim esetében végeztek hasonló kísérleteket, főként az általam is detektált $\beta$-glükozidáz alkalmazásával. GIRI és munkatársai (1954) Aspergillus flavus eredetü nyers micélium extraktummal 4-féle szénhidrát szintéziséről számoltak be. PANDEY és MISHRA (1997) Pichia etchellsii eredetü $\beta$-glükozidáz esetében mutattak ki transzglikozilációt, amellyel három különböző polimerizáltságú oligoszacharidot szintetizáltak. YAN és LIAU (1998) Aspergillus niger eredetü $\beta$-glükozidáz alkalmazásával cellobióz szubsztrátumon cellotriózt és gentiobiózt állítottak elő. A Pectinex ultra enzimkészítmény esetében is lehetséges a cellotrióz keletkezése. GAMA és MOTA (1998) Trichoderma reesei eredetű nyers celluláz (cellobiohidrolázt és endoglükanázt tartalmazó) készítmény esetében mutattak ki transzglükozilációs reakciót, cellobióz szubsztrátumon. A nyers enzimkészítménynek köszönhetően, a Pectinex ultra tartalmazhat több fajta celluláz enzimet, melyek együttesen katalizálhatják az oligoszacharid szintézist. SMAALI és munkatársai (2004) Sclerotinia sclerotiorum és Aspergillus niger eredetű $\beta$-glükozidáz enzimekkel szintetizáltak különböző glüko-oligoszacharidokat cellobióz szubsztrátumon, melyek szerkezetét is meghatározták: gentiobióz, cellotrióz, cellotetraóz.

\section{Maltóz}

A maltózt, az ipari izomalto-oligoszacharid előállítás szubsztrátumát, szintén fontos kiindulási anyagnak tartottam a Pectinex ultra oligoszacharid szintetizáló képességének tanulmányozásánál. Bizonyítottam, hogy az alkalmazott enzimkészítmény a maltózt is képes hidrolizálni,valamint azon glükozil transzfer reakciót katalizálni.

A keletkezett oligoszacharid a HPLC-RID vizsgálat során 6,805 percnél jelent meg. A retenciós idő alapján a szintetizált szénhidrát 3 glükóz egységből álló oligoszacharid. A hidrolitikus aktivitásnak köszönhetően a maltóz a biokonverzió 24. órájára szinte teljesen elfogyott és ezzel párhuzamosan nagy mennyiségü glükóz $(26,8 \mathrm{~g} / 100 \mathrm{ml})$ keletkezett. A keletkező glükóz mennyisége a cellobióz szubsztrátumon mért mennyiséghez képest kiemelkedő. Ez érdekesnek mondható, tekintve hogy a kromoforoszubsztrátumokon mért $\alpha$ - és $\beta$-glükozidáz aktivitás 
értékek közel azonosak voltak.Vélhetően ez esetben a reakció körülményei kedveztek a maltóz bontásnak vagy több olyan enzimet tartalmaz a készítmény melynek szubsztrátuma a maltóz.

A hidrolízis mellett transzglükozilációis végbe ment, amelynek köszönhetően az oligoszacharid maximális mennyisége szintén a 24. órában detektálható (terület=1083377 $\mu$ RIU*perc).

Eddig megjelent tanulmányokban, maltóz szubsztrátumon végbement transzglükozilációs reakciót az $\alpha$-glükozidáz (EC 3.2.1.20) (CRITTENDEN \& PLAYNE, 1996) és a glükoziltranszeráz

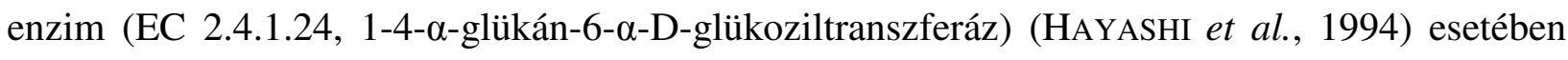
mutattak ki. Az $\alpha$-glükozidázok olyan exoenzimek, amelyek a terminális glikozidos kötéseket hasítják a szubsztrátum nem redukáló végén, ezzel $\alpha$-glükóz egységeket felszabadítva. Egy másik hidroláz enzim csoport, a glükoamilázok is képesek maltózt hidrolizálni, azonban nem képesek transzglikozilációs reakciót katalizálni (KRASIKOV et al., 2001). FERRER és munkatársai (2005) egy Ferroplasma acidiphilum eredetű $\alpha$-glükozidáz transzfer aktivitását tanulmányozva hasonló eredményt tapasztaltak, a reakció során szintén egy oligoszacharid terméket (maltotriózt) detektáltak. Az általam alkalmazott készítmény multienzim jellege miatt, ez esetben is felmerülhet több enzim együttes müködése.

\section{Trehalóz}

A trehalóz egy nem redukáló diszacharid, amely a legszélesebb körben megtalálható diszacharid gombákban, mind a vegetatív, mind a szaporodó gomba sejtjeiben (THEVELEIN, 1984). E szénhidrát jelentős szerepet játszik a gombák élettevékenységében. Nagy szerepük van a szénraktározásban, valamint a stressz elleni védelemben (JORGE et al., 1997).

$\mathrm{Az}$ általam alkalmazott enzimkészítmény gomba (Aspergillus acuelatus) eredetü, így mutat hidrolitikus aktivitást trehalóz szubsztrátumon is. Ezt bizonyítja, hogy a 96 órás biokonverzió során 0,6 g/100ml-röl 1,4 g/100ml-re növekedett a glükóz tartalom. A készítmény alkalmazásával csekély oligoszacharid képzés is megfigyelhető volt (kromatogram csúcs területe: $120250 \mu \mathrm{RIU} *$ perc), mely csak a biokonverzió 96. órájában volt kimutatható. A detektált termék a retenciója (6,83 perc) alapján feltételezhetően triszacharid.

A gombákban a trehalóz bioszintézise a trehalóz-6-foszfát-szintetáz és trehalóz-6-foszfátfoszfatáz enzimeknek köszönhető, hidrolízisüket a trehaláz ( $\alpha, \alpha$-trehalóz 1-D-glükohidroláz) enzim katalizálja (THEVELEIN, 1984). Már számos tanulmány beszámolt a gombákban található trehaláz enzimekről (HORIKOSHI \& IKEDA, 1966; D'ENFERT \& FONTAINE, 1997; D'ENFERT et al., 1999; PARrou et al., 2005). Ezen enzimek egyik fó jellemzője, hogy nem katalizálnak transzglikozilációs reakciót (DAHLQVIST, 1960). Korábban azt feltételezték, hogy az $\alpha$-glükozidázok nem képesek lebontani a trehalózban lévő $\alpha(1-1)$ glikozidos kötést (BERATIS et 
al., 1978), azonban újabb publikációk cáfolták ezt az elméletet (NAKAO et al., 1994; NASHIRU et al., 2001).

Esetünkben mind $\alpha$-glükozidáz, mind trehaláz enzim katalizálhatta a trehalóz hidrolízisét, ugyanis tisztítatlan formában használtam fel az enzimkészítményt. A trehalázokról ismert, hogy nem rendelkeznek transzferáz aktivitással, így az $\alpha$-glükozidáz enzim katalizálhatta a csekély transzfer reakciót.

Trehalóz oligoszacharidokról eddig kevés tanulmány jelent meg. KURIMOTO és munkatársai 1997-ben Aspergillus niger eredetü $\alpha$-glükozidáz enzim felhasználásával izomaltozil véget tartalmazó glikozil-trehalóz oligoszacharidokat szintetizáltak. Esetükben maltotetraózt alkalmaztak donorként és a trehalózt akceptorként.

\subsubsection{Glükozil-fruktózok}

Korábban azt tapasztaltam, hogy a Pectinex ultra készítmény képes glükobiózokon hidrolízis és transzfer reakciót katalizálni, illetve tanulmányok bizonyították a készítmény transzfruktozilációs aktivitását, ezért érdekesnek tartottam különböző glükozil-fruktózokon (turanózon, maltulózon, palatinózon) lejátszódó reakciókat megvizsgálni. A biokonverziók eredményeit a következő táblázat mutatja (13. táblázat).

13. táblázat: Szénhidrát összetétel változása a Pectinex ultra által katalizált transzglikozilációs reakciók során, glükozil-fruktóz szubsztrátumokon

\begin{tabular}{|c|c|c|c|c|c|}
\hline Szubsztrátum & $\begin{array}{l}\text { Termék } \\
\text { retenciós } \\
\text { ideje } \\
\text { (perc) }\end{array}$ & $\begin{array}{c}\text { Maximális } \\
\text { termék } \\
\text { terület } \\
\text { ( } \mu \text { RIU*perc) }\end{array}$ & $\begin{array}{c}\text { Glükóz } \\
\text { koncentráció } \\
\text { növekedés } \\
(\mathbf{g} / \mathbf{1 0 0 m l})\end{array}$ & $\begin{array}{c}\text { Fruktóz } \\
\text { koncentráció } \\
\text { növekedés } \\
\text { (g/100ml) }\end{array}$ & $\begin{array}{c}\text { Szubsztrátum } \\
\text { koncentráció } \\
\text { csökkenés } \\
\text { (g/100ml) }\end{array}$ \\
\hline turanóz & 6,87 & 668843 & 0,8 & 0,92 & 2,3 \\
\hline maltulóz & 6,86 & 1377514 & 0,69 & 1,1 & 3,22 \\
\hline palatinóz & 6,80 & 1476973 & 1,52 & 2,16 & 5,7 \\
\hline
\end{tabular}

(paraméterek: pH 5,5, $60{ }^{\circ} \mathrm{C}, 30$ g/100ml szubsztrátum koncentráció, 96 óra, detektálás: HPLC-RID technika)

\section{Turanóz}

A turanóz egy glükóz és egy fruktóz egységből álló redukáló diszacharid, amelyben $\alpha(1-3)$ glikozidos kötés található. Eredményeim bizonyítják, hogya Pectinex ultraenzimkészítmény alkalmazásával hidrolizálható a turanóz és oligoszacharid szintézis is megvalósítható.

A hidrolízis termékek mennyiségének alakulását elemezve megállapítható, hogy a fruktóz koncentrációjának növekedése $(0,92 \mathrm{~g} / 100 \mathrm{ml})$ kis mértékben, de nagyobb volt a glükóz koncentráció $(0,81$ g/100ml) emelkedésénél. Ennek az lehet az oka, hogy az enzimkészítmény transzglükozilációs reakciót valósított meg a turanózon. Az eredményt GHAZI és munkatársai 
(2007) által végzett tanulmány is alátámasztja, ugyanis megállapították, hogy a Pectinex ultra készítményben található fruktoziltranszferáznak nem szubsztrátuma a turanóz.

Az oligoszacharid képződés a maltóz szubsztrátumon elért eredményekhez képest kisebb volt (maximális terület érték: $668843 \mu$ RIU*perc, retenciós idő: 6,87), a legnagyobb oligoszacharid koncentráció a biokonverzió 48. órájában volt detektálható. A termék feltételezhetően hármas polimerizáltságú.

Eddigi tanulmányok főként a turanóz $\alpha$-glükozidáz enzimre kifejtett gátló hatásáról számoltak be (AuricChio \& Bruni, 1967; PALMER, 1971; GufFanTI \& CORPE,1976). Újabban már vannak adatok arról is, hogy egyes $\alpha$-glükozidáz enzimek a turanózt is képesek szubsztrátumként felismerni. TAKEWAKI és munkatársai (1993) méh rovarból izolált $\alpha$-glükozidáz enzim szubsztrátum specifitását vizsgálták és megállapították, hogy számos glükobióz mellett az enzim képes volt a turanózt is hidrolizálni. NASHIRU és munkatársai (2001) is közölték, hogy a Thermus caldophilus GK24 eredetü $\alpha$-glükozidáz enzim széles szubsztrátum specifikussággal rendelkezik. Ez az enzim izomaltózon mutatta a legnagyobb aktivitást, viszont turanóz szubsztrátumon is glükóz képződést detektáltak, amely csupán 54,8\%-a volt az izomaltózon elért hidrolitikus aktivitásnak. LUNINA és munkatársai (2003) Thermotoga neapolitana eredetű $\alpha$-glükozidázzal ugyancsak kimutattak hidrolitikus aktivitást turanózon. MiNAMI és munkatársai (1990) az oligoszacharid szintézist is tanulmányozták turanóz szubsztrátum jelenlétében. A Streptococcus mutans MT8148 és Streptococcus sobrinus 6715 törzsek glükoziltranszferáz enzimét vizsgálták különböző szacharóz analóg szénhidrátokon. Kimutatták (MINAMI et al., 1990), hogy a vizsgált diszacharidok mindegyike, a turanóz kivételével, szacharózzal kombinálva gátolja a transzfer reakciót. Turanóz és szacharóz együttes alkalmazásával azonban fokozni tudták az oligoszacharid képzését (MinAmi et al., 1990). RoBYT és EKLUND1983-ban (1983) a Leuconostoc mesenteorides eredetü dextránszukráz enzimet vizsgálták. Kimutatták, hogy szacharóz:turanóz biszubsztrátum rendszerben a turanóz akceptorként vehet részt. Egyes tanulmányok arról is írnak, hogy a ciklodextrin-glükanotranszferáz enzim által katalizált reakcióban is részt vehet akceptorként a turanóz (PLOU et al., 2002; WeIJERS et al., 2008).

A kísérleteimben nem egészítettük ki a turanózt más szénhidráttal. Így arra következtethetünk, hogy a turanóz diszacharidon mutatott transzglikoziláció a készítmény $\alpha$-glükozidáz enzimének tudható be.

\section{Maltulóz}

A doktori kutatásom során megvizsgáltam a készítmény hidroláz/transzferáz aktivitását maltulóz szubsztrátumon is. Az 16. ábrán bemutatott eredmények alapján megállapítható, hogy Pectinex ultra hidrolizálta a maltulózt és emellett transzglikozilációt katalizált (nagyobb polimerizáltságú 
oligoszacharidok detektálhatók). A transzglikozilációnak köszönhetően oligoszacharid szintetizálódott, amelynek maximális mennyiségét a 48. órában mértem (kromatogram csúcs területe: $1377514 \mu$ RIU*perc). A hidrolízis termékek közül, a fruktóz mennyiségének növekedése $(1,1 \mathrm{~g} / 100 \mathrm{ml}$, a reakció nagyobb mértékü volt, mint a glükóz koncentráció növekedése $(0,69 \mathrm{~g} / 100 \mathrm{ml})$ a reakció 96 . órájára. Ezek alapján feltételezhető a transzglükozilációs reakció végbemenetele.

A maltulózról, mind szubsztrátumként (hidrolízis), mind termékként (szintézis) főként az a-glükozidáz enzimmel kapcsolatban található irodalom (SUGAWARA et al., 1961; SUGAWARA, 1963; TÄUfEL et al., 1967; KANG et al., 2009; POKUSAEVA et al., 2009). E szubsztrátumot még nem vizsgálták oligoszacharid szintézis céljából.

\section{Palatinóz}

A palatinóz egy természetben is előforduló - egy glükóz és egy fruktóz molekulából álló diszacharid, amely $\alpha(1-6)$-os glikozidos kötést tartalmaz. A palatinóz-oligoszacharidok előállítása iparilag megvalósított, melyet a palatinóz intermolekuláris dehidratációjával állítanak elő (PRAPUlla et al., 2000). Megállapítottam, hogy a palatinóz is szubsztrátuma az enzimkészítménynek. A reakció során mind hidrolízis termékek, mind transzfer termékek megjelentek. A Pectinex ultra alkalmazásával a palatinózon vélhetően triszacharidokat (retenciós idő: 6,80 perc) állítottam elő. A keletkezett termék maximális mennyiségét (1476973 $\mu$ RIU*perc) a biokonverzió 24. órájában detektáltam. A monoszacharidok koncentrációjának alakulásából arra következtethetünk, hogy transzglükozilációs reakció ment végbe. Az általam vizsgált diszacharidok közül a palatinóz szubsztrátumon volt kimutatható a készítmény legnagyobb mértékű oligoszacharid szintézis, e diszacharid esetében detektáltam a legnagyobb termék terület értéket.

Eddig megjelent tanulmányok szerint a palatinóz szubsztrátumon történő hidrolízisért és a transzglükozilációs reakcióért az $\alpha$-glükozidáz enzim a felelős (PILLER et al., 1996; VAN DEN Broek 2003; LeHner et al., 2006; PoKusAeva et al., 2009). A kapott eredmények rámutattak arra, hogy a Pectinex ultra tartalmaz olyan $\alpha$-glükozidáz enzimet, amely széles szubsztrátum specifitással rendelkezik, így alkalmazásával lehetséges különböző összetételü/szerkezetü oligoszacharidok előállítása.

\subsubsection{Galaktozil-glükóz}

Az a-galaktozidos kötést tartalmazó oligoszacharidok (szója-oligoszacharidok) kimagasló részesei a kereskedelmi forgalomban kapható prebiotikus szénhidrátoknak. Az aktivtitásvizsgálat eredményei azt mutatták, hogy a készítmény jelentős mennyiségű (10,4 U/ml) a-galaktozidáz enzimet tartalmaz (10. táblázat). Az $\alpha$-galaktozidázok (E.C. 3.2.1.22) exo-glikozidáz enzimek, 
amelyek különböző oligo- és poliszachariok terminális galaktóz egységét hasítják le (NGUYEN et al., 2015). Emellett az $\alpha$-galaktozidáz az $\alpha$-galaktozidos kötések hidrolízise mellett azok létrehozására is alkalmas lehet. A transzglikozilációs reakciót melibióz szubsztrátum alkalmazásával tanulmányoztam.

14. táblázat: Szénhidrát összetétel változása a Pectinex ultra által katalizált transzglikozilációs reakció során, melibióz szubsztrátumon

\begin{tabular}{|c|c|c|c|c|c|}
\hline Szubsztrátum & $\begin{array}{l}\text { Termék } \\
\text { retenciós } \\
\text { ideje } \\
\text { (perc) }\end{array}$ & 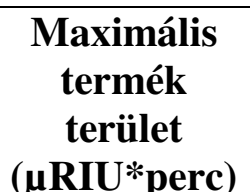 & $\begin{array}{c}\text { Glükóz } \\
\text { koncentráció } \\
\text { növekedés } \\
(\mathbf{g} / \mathbf{1 0 0 m l})\end{array}$ & $\begin{array}{c}\text { Galaktóz } \\
\text { koncentráció } \\
\text { növekedés } \\
(\mathbf{g} / \mathbf{1 0 0 m l})\end{array}$ & $\begin{array}{c}\text { Szubsztrátum } \\
\text { koncentráció } \\
\text { csökkenés } \\
(\mathrm{g} / \mathbf{1 0 0 m l})\end{array}$ \\
\hline melib & 6,92 & 3313266 & 4,6 & 2,77 & 10,71 \\
\hline
\end{tabular}

(paraméterek: pH 5,5, $60{ }^{\circ} \mathrm{C}, 30 \mathrm{~g} / 100 \mathrm{ml}$ szubsztrátum koncentráció, 96 óra, detektálás: HPLC-RID technika)

Eredményeim alapján megállapítottam (14. táblázat), hogy a Pectinex ultra $\alpha$-galaktozidáz enzime képes a melibiózt lebontani glükózzá és galaktózzá. Emellett megfigyelhető egy (feltételezhetően) 3-as polimerizáltságú oligoszacharid termék megjelenése is, amelynek a retenciós ideje HPLC-RID módszerrel 6,92 perc. A termék maximális mennyiségét a biokonverzió 48. órájában detektáltam (terület érték: $3313266 \mu$ RIU*perc). A szénhidrát összetétel alakulásából arra lehet következtetni, hogy az oligoszacharid termék szintézise transzgalaktozilációs reakciónak tudható be. Ezt bizonyítja, hogy a reakció során kisebb mértékü volt a galaktóz mennyiségi növekedése a glükózéhoz képest.

Már 1964-ben Li és SHETLAR (1964) egy Diplococcus pneumoniae eredetü a-galaktozidáz enzimmel különböző $\alpha$-galaktozidos kötést tartalmazó oligoszacharidokat szintetizáltak melibiózból. Esetükben 9 féle oligoszacharid szintetizálódott. HASHIMOTO és munkatársai 1995ben (1995) egy fö oligoszacharid terméket szintetizáltak Candida guilliermondii eredetü a-galaktozidáz enzim felhasználásával. TzORTZIS és munkatársai 2003-ban (2003) szintén hasonló eredményeket kaptak. Melibióz szubsztrátumon $\mathrm{DP}_{3}$ oligoszacharidot szintetizáltak Lactobacillus reuteri eredetủ a-galaktozidáz enzimmel (TzORTZIS et al., 2003). Meghatározták a termék szerkezetét is. A szintetizált oligoszacharid 6-galaktozil-melibióz volt. Ez a triszacharid a Penicillium oxalicum eredetű $\alpha$-galaktozidázzal szintén képezhető (KURAKAKE et al., 2011). Aspergillus aculeatus eredetű $\alpha$-galaktozidáz enzim transzfer aktivitásáról még nem jelent meg tanulmány, így a melibióz szubsztrátumon elért eredményem újnak tekinthető és alapjául szolgálhat $\alpha$-galaktozidos kötést tartalmazó szénhidrátok elöállításának. 


\subsubsection{Reverz hidrolízis Pectinex ultra enzimkészítménnyel}

A di- és oligoszacharidok előállításának egyik módja a reverz hidrolízis reakciók alkalmazása. Kutatómunkámban reverz hidrolízist is tanulmányoztam a következő monoszacharid szubsztrátumokkal: arabinóz, ramnóz, szorbóz, xilóz, fruktóz, glükóz és mannóz.

\section{5. táblázat: Szénhidrát összetétel változása Pectinex ultra által katalizált reverz} hidrolízis reakciók során, mannózon és glükózon

\begin{tabular}{|c|c|c|c|}
\hline Szubsztrátum & $\begin{array}{c}\text { Termék(ek) } \\
\text { retenciós ideje } \\
\text { (perc) }\end{array}$ & $\begin{array}{c}\text { Maximális } \\
\text { termék terület } \\
(\mu \mathrm{RIU} * \text { perc })\end{array}$ & $\begin{array}{c}\text { Szubsztrátum } \\
\text { koncentráció csökkenés } \\
(\mathrm{g} / \mathbf{1 0 0 m \mathrm { m } )} \\
\end{array}$ \\
\hline \multirow{2}{*}{ glükóz } & 7,39 & 281763 & \multirow{2}{*}{1,59} \\
\hline & 6,8 & 2269338 & \\
\hline mannóz & 7,57 & 1377345 & 1,98 \\
\hline
\end{tabular}

(paraméterek: $\mathrm{pH}$ 5,5, $60{ }^{\circ} \mathrm{C}, 30 \mathrm{~g} / 100 \mathrm{ml}$ szubsztrátum koncentráció, 96 óra, detektálás: HPLC-RID technika)

\section{Glïkóz}

A glükóz szubsztrátumon végzett biokonverziós kísérlet során különböző szénhidrát termékek szintetizálódtak, amelyek retenciós ideje (Termék1: 6,8 és Termék2: 7,32 perc) alapján di- és triszacharidok lehetnek (15. táblázat). Mennyiségük a 96. órás biokonverzió végén volt a legnagyobb (Termék1: $2269338 \mu$ RIU*perc, Termék2: $281763 \mu$ RIU*perc).

Az eddigi tanulmányok alapján, számos enzim esetében kimutattak már reverz hidrolízis reakciót glükóz szubsztrátumon. Főként $\beta$-glükozidáz enzim alkalmazásával kapcsolatban mutattak ki oligoszacharid szintézist (AJISAKA et al., 1987; SALOHEIMO et al., 2002; BRUINS et al., 2003a). Korábban bizonyításra került, hogy a készítmény rendelkezik $\beta$-glükozidáz aktivitással, amelynek köszönhetően képes a cellobióz bontására és e diszacharidon oligoszacharidot szintetizálni. Ezen enzim jelenléte magyarázhatja a glükóz monoszacharidon történő reverz hidrolízis reakciót.

Az $\alpha$-glükozidos kötést bontó enzimek szintén rendelkezhetnek reverz hidrolízis aktivitással (Pestlin et al., 1997; RASTAll et al., 1991; MAlÁ \& KRÁlovÁ, 2000; ChITRADON et al., 2000). Korábban bizonyításra került, hogy a Pectinex ultra készítmény $\alpha$-glükozidáz enzimet is tartalmaz, így ezen enzim is katalizálhatta a reakciót. MALÁ és KRÁLOVÁ 2000-ben (2000) Bacillus stearothermophilus eredetű $\alpha$-glükozidáz enzim segítségével szintetizáltak különböző a-glükozidos kötést tartalmazó diszacharidot. Termékek között megtalálható volt izomaltóz, nigeróz, maltóz és kojibióz. Annak megállapítására, hogy mely enzim katalizálta a reakciót, további vizsgálatokra lenne szükség. 


\section{Mannóz}

Napjainkban a mannóz alapú oligoszacharidok szintézisére nagy érdeklődés mutatkozik, ugyanis ezek a szénhidrátok jelen vannak számos glikoproteinben illetve jelentős anti-adhéziós tulajdonsággal is rendelkeznek. Gyakorlatban az $\alpha$-mannozidáz enzim segítségével állítják elő, így a munkámban célul tủztem a készítmény ezen aktivitásának vizsgálatát is.

Mannóz szubsztrátumot alkalmazva a biokonverzió során egy 7,57 perc retenciós idejü csúcs növekedését detektáltam (15. táblázat). Ez a komponens feltételezhetően diszacharid. A legnagyobb mennyiségben a 96. órában vett mintában volt kimutatható (területe: $1377345 \mu$ RIU*perc). A mannobióz képzését a Pectinex ultra készítményében található a-mannozidáz aktivitásának tulajdonítom, hiszen számos irodalmi példa van arra, hogy a-mannozidáz enzimek katalizálják az oligoszacharid szintézist (reverz hidrolízis reakcióval) mannózt tartalmazó közegben (JOHANSSON et al., 1986, 1989; AJISAKA et al., 1995; SiNGH et al., 2000; MAITIN \& RASTALL, 2007). A reverz hidrolízist elsősorban a gomba; Aspergillus niger (AJISAKA et al., 1995; Singh et al., 2000), Aspergillus phoenicus (ATHANASOPOUlOS et al., 2004), Penicillium citrium (MAITIN et al., 2004) eredetü $\alpha$-mannozidázoknál tapasztalták, de néhány növény eredetü; mandula (SINGH et al., 2000) és Canavalia ensiformis (egy babfajta) (JoHANSSON et al., 1986; 1989); is rendelkezik e tulajdonsággal.

A reverz reakció során keletkezett mannobiózt felépítő mannóz egységek többféleképpen kapcsolódhatnak egymáshoz: $\alpha(1-2), \alpha(1-3), \alpha(1-6)$ (MAITIN \& RASTALL, 2004). Egy adott a-mannozidáz enzim többféle kötés kialakítására is képes lehet, tehát többféle kötést tartalmazó termékek lehetnek jelen a reakcióelegyben, azonban vannak nagy régiospecifitást mutató $\alpha$-mannozidázok is. A szintetizált termékek további jellemzése a 4.1.5 fejezetben található.

A szintézis reakciót arabinóz, ramnóz, szorbóz, xilóz és fruktóz monoszacharidokon is vizsgáltam. E szubsztrátumok esetében nem detektáltam termékképzést.

\subsubsection{Transzglikoziláció Bifidobacterium longum eredetü enzimpreparátummal}

A bifidobaktérium eredetü glikozidáz enzimeknek jelentős szerepe van a prebiotikus szénhidrátok hasznosításában. Kutatómunkámban ezen enzimeket egy másik aspektusból, oligoszacharid szintézis szempontjából tanulmányoztam. Ehhez egy Bifidobacterium longum Bb-46 (probiotikum) eredetü enzimpreparátumot állítottam elő, melyhez előzőleg a törzset laktóz szénforrást tartalmazó tápközegben szaporítottam. Ennek köszönhetően a preparátum rendelkezett $\beta$-galaktozidáz aktivitással $(0,4 \quad \mathrm{U} / \mathrm{ml})$, számos más aktivitás mellett (pl. $\alpha$-glükozidáz, $\beta$-glükozidáz, $\alpha$-galaktozidáz, $\beta$-fruktozidáz). Az oligoszacharid szintézist különböző diszacharidokon, laktózon, laktulózon, maltózon és szacharózon tanulmányoztam, 30 g/100ml szubsztrátum koncentráció, pH 6,6 és $40{ }^{\circ} \mathrm{C}$ paraméterek alkalmazásával. 
Megállapítottam, hogy a preparátummal mindegyik vizsgált diszacharidon lehetséges oligoszacharidok előállítása (16. táblázat).

16. táblázat: Szénhidrát összetétel változása Bifidobacterium longum Bb-46 eredetü preparátummal végzett biokonverziók során

\begin{tabular}{|c|c|c|c|c|c|}
\hline Szubsztrátum & $\begin{array}{l}\text { Termék } \\
\text { retenciós } \\
\text { ideje } \\
\text { (perc) }\end{array}$ & $\begin{array}{c}\text { Maximális } \\
\text { termék } \\
\text { terület } \\
\text { ( } \mu \text { RIU*perc) }\end{array}$ & $\begin{array}{c}\text { Glükóz } \\
\text { koncentráció } \\
\text { növekedés } \\
\text { (g/100ml) }\end{array}$ & $\begin{array}{c}\text { Fru/Gal* } \\
\text { koncentráció } \\
\text { növekedés } \\
\text { (g/100ml) }\end{array}$ & $\begin{array}{c}\text { Szubsztrátum } \\
\text { koncentráció } \\
\text { csökkenés } \\
(\mathrm{g} / \mathbf{1 0 0 m l})\end{array}$ \\
\hline Laktóz & $\begin{array}{l}7,17 \\
8,24\end{array}$ & $\begin{array}{c}146247 \\
4664435\end{array}$ & 0,71 & 0,788 & 2,62 \\
\hline Laktulóz & $\begin{array}{l}7,16 \\
8,35\end{array}$ & $\begin{array}{c}130594 \\
3849667\end{array}$ & - & 0,87 & 1,95 \\
\hline Maltóz & $\begin{array}{l}7,22 \\
7,57 \\
8,35\end{array}$ & $\begin{array}{c}283600 \\
798240 \\
4527066\end{array}$ & 1,05 & - & 1,85 \\
\hline Szacharóz & $\begin{array}{l}7,31 \\
8,10\end{array}$ & $\begin{array}{l}5994260 \\
1526998\end{array}$ & - & 3,36 & 7,23 \\
\hline
\end{tabular}

(paraméterek: $\mathrm{pH} 6,6,40{ }^{\circ} \mathrm{C}, 30 \mathrm{~g} / 100 \mathrm{ml}$ szubsztrátum koncentráció, 96 óra, detektálás: HPLC-RID technika)

*Fru: fruktóz, Gal:galaktóz

HPLC-RID vizsgálattal a laktózon kétféle terméket detektáltam, melyek retenciós idejük alapján trimer $(8,24$ perc, $4664435 \mu$ RIU*perc) és tetramer (7,17 perc, $146247 \mu$ RIU*perc $)$ oligoszacharidok, amelyek maximális mennyisége a reakció 96. órájában volt mérhető. Továbbá kimutattam, hogy a reakció során nagyobb mennyiségben keletkezik glükóz, mint galaktóz. Ebből arra következtethetünk, laktózon transzgalaktozilációs reakció ment végbe, mely a korábban már kimutatott $\beta$-galaktozidáz enzim jelenlétének tudható be. Korábban Hsu és munkatársai (2007) hasonló eredményt kaptak. A Bifidobacterium longum BCRC15708 törzs $\beta$-galaktozidáz enzimével szintén tri- és tetramer galakto-oligoszacharidokat szintetizáltak.

Oligoszacharid szintézist tapasztaltam laktulóz szubsztrátumon is. Ez esetben a laktózon detektált termékekkel közel azonos retenciójú szénhidrátok jelentek meg. Ezek maximális terület értékei szintén a 96. órában voltak mérhetők, azonban mennyiségük kisebb volt (trimer: 8,35 perc, $3849667 \mu$ RIU*perc, tetramer: 7,16 perc, $130594 \mu$ RIU*perc). Az alkalmazott HPLCRID módszerrel a galaktóz és a fruktóz retenciója közel esnek egymáshoz, így nem következtethettem a laktulózon végbemenő transzglikozilációs reakció típusára. Eddig megjelent tanulmányokban azonban laktulóz szubsztrátumon történő oligoszacharid szintézisről csak a $\beta$-galaktozidázok által katalizált transzgalakozilációs reakció kapcsán számoltak be (CARDELLECOBAS et al., 2008; MARTÍNEZ-VILlALUENGA et al., 2008; GUERRERO et al., 2011).Véleményem szerint e biokonverziónál is a preparátum $\beta$-galaktozidáz enzime katalizálta az oligoszacharid szintézist. Bifidobacterium eredetű $\beta$-galaktozidáz esetében még nem számoltak be transzgalaktozilációs reakcióról. 
Maltózon transzglükozilációs reakció ment végbe, melynek köszönhetően 3 oligoszacharid terméket detektáltam. A három termék maximális mennyisége a biokonverzió 72. órájában volt mérhető (trimer: 8,35 perc, $4527066 \mu$ RIU*perc, trimer: 7,57 perc 798240 $\mu$ RIU*perc, tetramer: 7,22 perc $283600 \mu \mathrm{RIU}$ *perc). E reakciót vélhetően a preparátum $\alpha$-glükozidáz enzime katalizálta. Korábban VAN DEN BROEK és munkatársai (2003) a Bifidobacterium adolescentis DSM20083 $\alpha$-glükozidáz enzimének vizsgálatakor azt tapasztalták, hogy a mikroba kétféle $\alpha$-glükozidázos kötést bontó enzimet termel oligo-1,6-glükozidázt (EC 3.2.1.10) és $\alpha$-glükozidázt (EC 3.2.1.20). Az előbbi traszglükozilációval trehalózból és szacharózból volt képes oligoszacharidokat szintetizálni, ezzel szemben az utóbbi enzimnél maltózból, melicitózból és szacharózból figyeltek meg termékképzés.

Szacharóz szubsztrátumon szintén mutattam ki transzglükozilációs reakciót így a VAN DEN BROEK és munkatársai (2003) által kimutatott enzimek jelenléte feltételezhető az általam alkalmazott preparátumban is. E szubsztrátumon detektáltam a legnagyobb termék terület értékeket (trimer: 8,10 perc, $5994260 \mu$ RIU*perc, tetramer: 7,31 perc, $5994260 \mu$ RIU*perc), melyeket a maltóz szubsztrátumhoz hasonlóan a biokonverzió 72. órájában értem el, glükóz képződését nem detektáltam. Érdekes eredmény, hogy e szubsztrátum esetén a nagyobb polimerizáltságú termék keletkezett nagyobb mennyiségben.

\subsubsection{Különbözö paraméterek hatása a mannóz alapú di/oligoszacharidok szintézisére}

A 4.1.2 fejezetben a Pectinex ultra enzimkészítménnyel, mannóz szubsztrátumon elért eredmények illetve a mannóz alapú oligoszacharidok nagy jelentősége miatt e reakciót tartottam fontosnak tovább tanulmányozni, azon belül is különböző paraméterek hatását vizsgálni.

\subsubsection{Szubsztrátum koncentráció}

A szubsztrátum koncentrációnak meghatározó szerepe van az oligoszacharidok szintézisénél. Ismert tény, hogy a magas szubsztrátum koncentráció kedvezően befolyásolja mind a transzglikozilációs, mind pedig a reverz hidrolízis reakciót. A szubsztrátum koncentráció növelésével (vízaktivitás csökkenésével) a reverz reakciók esetében eltolható az egyensúly a szintézis irányába. Továbbá, a nagy szubsztrátum koncentráció másik fontos előnye, hogy megvédi az enzimet a hődenaturációtól.

A mannózon történő oligoszacharid szintézis optimális szubsztrátum tartalmának meghatározásához biokonverziós kísérleteket végeztem pH 6,5 és 60 C ${ }^{\circ}$ paraméterek mellett és a 96. órában mért relatív hozamokat hasonlítottam össze.

A szubsztrátum koncentráció emelésével (20 - 60\%) növekedett a mannobióz mennyisége (12. ábra). A legnagyobb termék hozam 60 g/100ml szubsztrátum koncentrációval érhető el. Ez 
az érték kisebb a szakirodalomban publikált eredményeknél. Az esetek többségében általában 70 - 85\% mannóz koncentráció tartományban határozták meg az optimumot (JOHANSSON et al., 1989, SuWASONO \& RASTAll, 1996). Vannak kivételek pl. AtHanASOPOUlos és munkatársai (2004) által publikált eredmények (40 - 45\%), akik az Aspergillus phoenicus eredetü $\alpha$-mannozidázt vizsgálták.

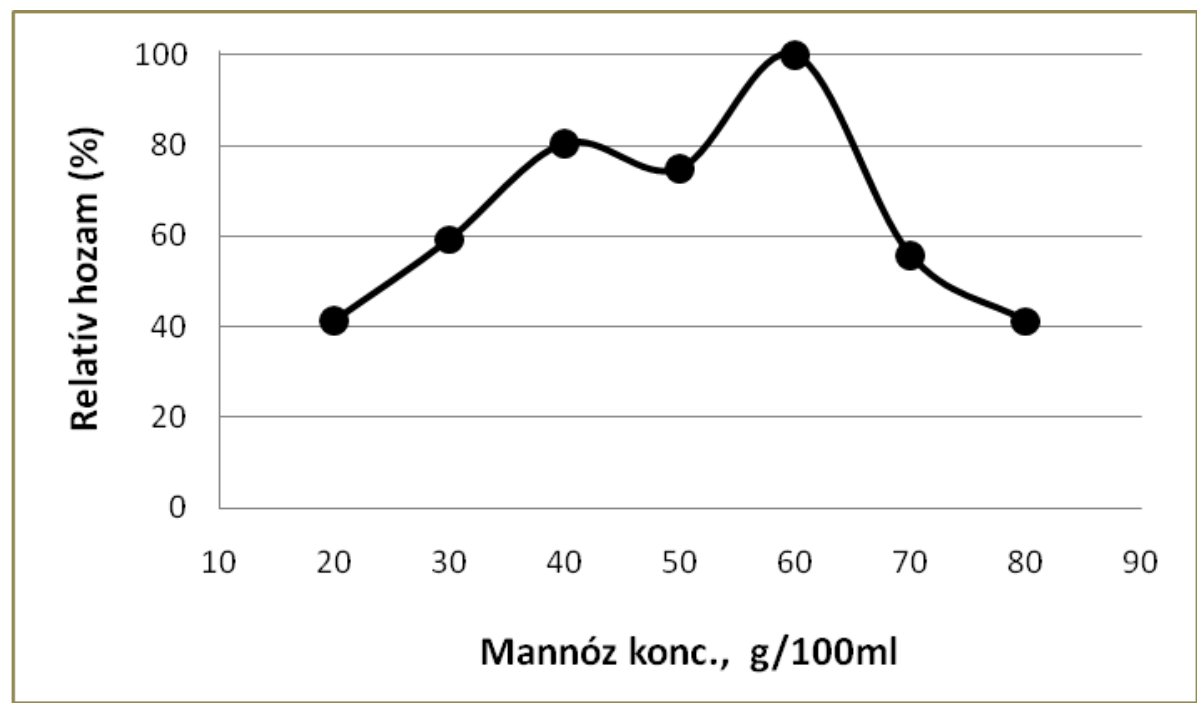

12. ábra: Mannóz koncentráció hatása a Pectinex ultra termék szintézisére (paraméterek: $\mathrm{pH} 6,5,60^{\circ} \mathrm{C}, 96$. óra, detektálás: HPLC-RID technika)

\subsubsection{2 pH és hőmérséklet}

A pH és hőmérséklet hatásának vizsgálatához az előző kísérletekhez hasonlóan 96 órás biokonverziót hajtottam végre, 60 g/100ml mannóz koncentráció alkalmazásával. A reakció további paramétereit nem változtattam. A 96. órában kapott relatív hozamokat hasonlítottam össze. A termék képzés szempontjából optimális pH meghatározásához McIlvaine puffereket alkalmaztam (pH 3,0 - 7,0).

A 13.A. ábrán jól látható, hogy a legnagyobb hozamot pH 5,0 érték alkalmazásával kaptam. Mind a savas mind a lúgos tartomány felé haladva gyors ütemü csökkenés tapasztalható. ATHANASOPOULOS és munkatársai (2004) Aspergillus phoenicus eredetű $\alpha$-mannozidáz esetében szintén vizsgálták a pH hatását, ők kis eltéréseket tapasztaltak a pH változtatásával. A hozam 14 - 18 w/w \% értékek között változott pH 3,5 - 6,0 tartományban. Az általuk meghatározott optimum pH 4,0 - 5,0 volt. Megjegyzem, hogy számos tanulmány nem vizsgálja a pH hatását, csupán az enzim hidrolitikus aktivitása esetén meghatározott optimumot alkalmazzák.

A hőmérséklet hatásának vizsgálata $50-80{ }^{\circ} \mathrm{C}$ tartományban került megvalósításra (13.B. ábra). A legnagyobb termék hozamot $70{ }^{\circ} \mathrm{C}$-on történő biokonverziónál kaptam. Az egyensúlyi szintézis reakciókat általában 50 - $60{ }^{\circ} \mathrm{C}$ tartományban hajtják végre (MAITIN \& RASTALL, 2007). 
ATHANASOPOULOS és munkatársai (2004) szintén ebben a tartományban határozták meg az Aspergillus phoenicus eredetü $\alpha$-mannozidáz hőmérséklet optimumát. A legnagyobb oligoszacharid hozamot $55^{\circ} \mathrm{C}$-on mutatta az enzim.

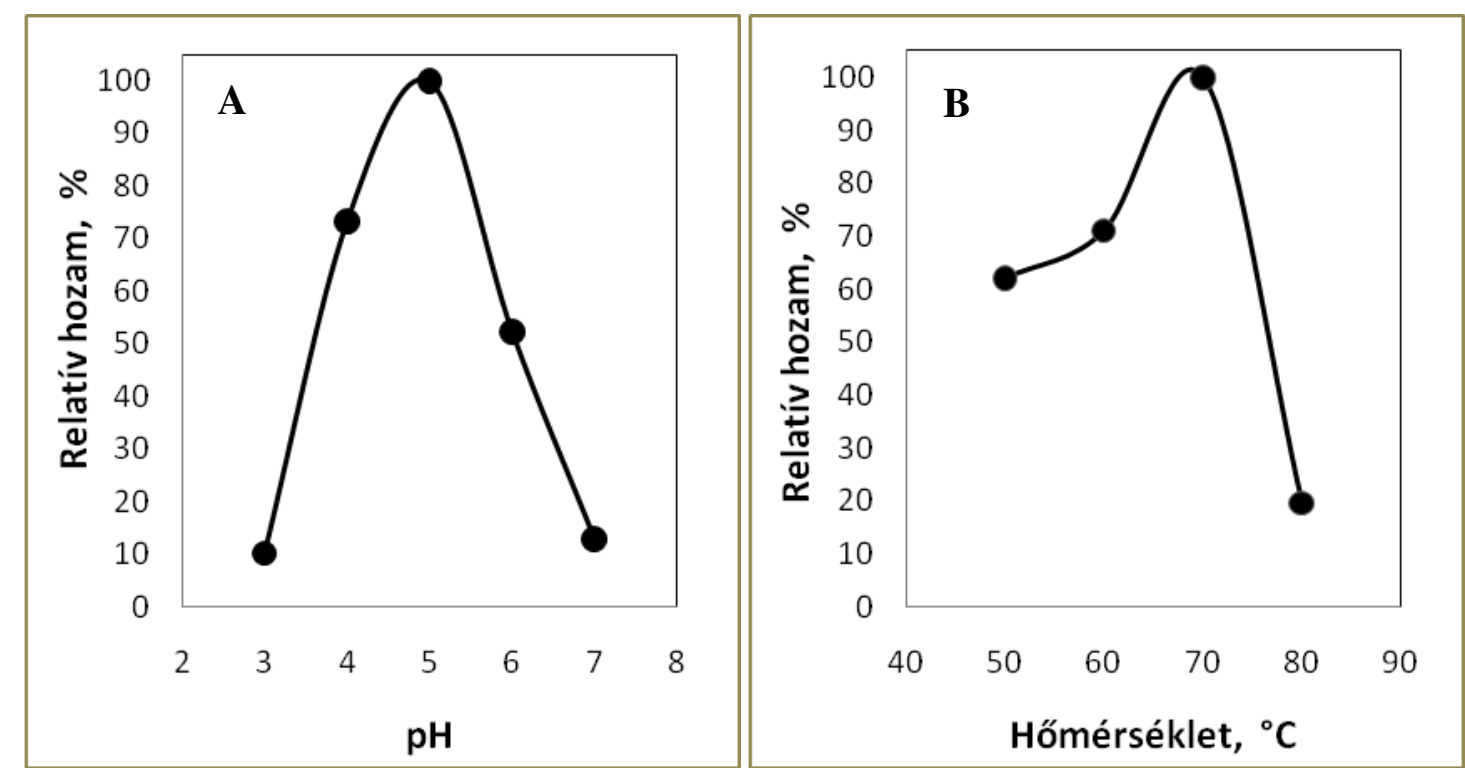

\section{3. ábra: A Pectinex ultra által katalizált mannóz alapú szintézis pH (A) és hőmérséklet (B) függése}

(paraméterek: $\mathrm{pH} 5,0$ hőmérséklet függés esetén, $60^{\circ} \mathrm{C} \mathrm{pH}$ függés esetén, 60 g/100ml mannóz koncentráció, 96. óra, detektálás: HPLC-RID technika)

\subsubsection{Enzim:szubsztrátum arány}

A mannóz szubsztrátumon végzett reverz hidrolízis reakció esetében vizsgáltam az enzimmennyiség hatását a termék szintézis fokozása érdekében. A vizsgált enzim:szubsztrátum arányok a következök voltak: 0,$77 ; 1,9 ; 2,7 ; 3,1 ; 3,5 ; 3,9 \mathrm{mg}$ fehérje/g szubsztrátum. A kiértékeléshez a 96. órában mért relatív össztermék hozamokat hasonlítottam össze.

A HPLC-RID vizsgálat során egy újabb, nagyobb polimerizáltságú terméket is detektáltam, amelynek retenciója 6,7 perc volt. Ez a szénhidrát az alkalmazott analitikai oszlop specifikáltsága alapján triszacharid lehetett és csak kis mennyiségben keletkezett a reakció során, kb. egy nagyságrenddel kisebb jelet adott (maximális kromatogram-csúcs területe: 782273 $\mu$ RIU*perc) a kromatogramon a már korábban detektált termékhez képest. Ez azzal magyarázható, hogy bizonyos enzim:szubsztrátum arányok alkalmazása fokozta a reverz hidrolízis reakciót magasabb polimerizáltságú termék megjelenését eredményezve. Az enzim:szubsztrátum arány hatásának vizsgálatakor a két termék együttes mennyiségét vettem figyelembe. Megállapítottam, hogy a maximális termék hozam (mannobióz és mannotrióz összege) a 3,1 mg fehérje/g enzim:szubsztrátum aránynál érhető el. Az enzim mennyiség tovább növelésével nem fokozható a hozam (14. ábra). 


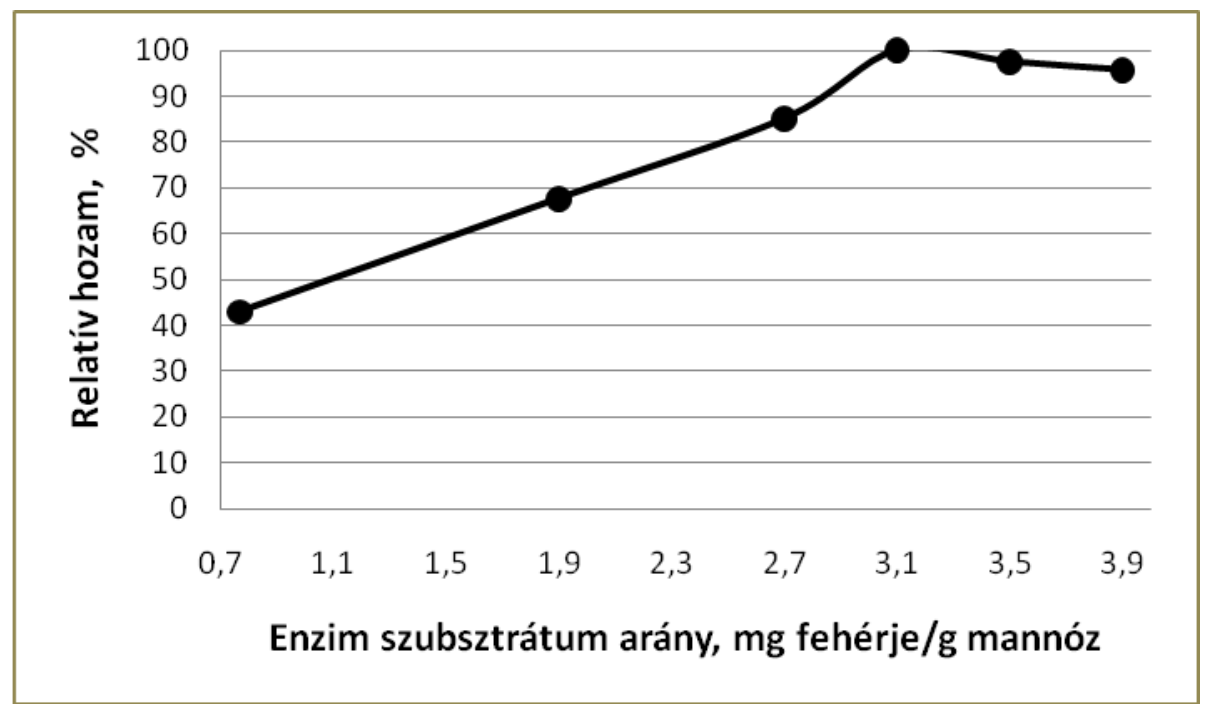

14. ábra: A Pectinex ultra mennyiségének hatása a mannobióz és mannotrióz szintézisre (paraméterek: $\mathrm{pH} 5,0,70{ }^{\circ} \mathrm{C}, 60 \mathrm{~g} / 100 \mathrm{ml}$ mannóz koncentráció, 96. óra, detektálás: HPLC-RID technika)

\subsubsection{Maillard inhibitorok hatása}

A szénhidrát szintézist gátolhatja a reakció során bekövetkező enzim-inaktiválódás. Ennek egyik oka lehet az enzim aminosav alkotói és a szubsztrátum között végbemenő Maillard reakció. A mannóz alapú szénhidrát szintézis során 3 Maillard reakciót gátló vegyület hatását vizsgáltam: o-fenilén-diamin-dihidroklorid (OPD), szemikarbazid-hidroklorid (SMC) és a aminoguanidinhidroklorid (AG). Megállapítottam, hogy a 3 inhibitor közül csupán az AG alkalmazásával növelhető a termékek szintézise. Az OPD és az SMC gátolták a termékek szintézisét.

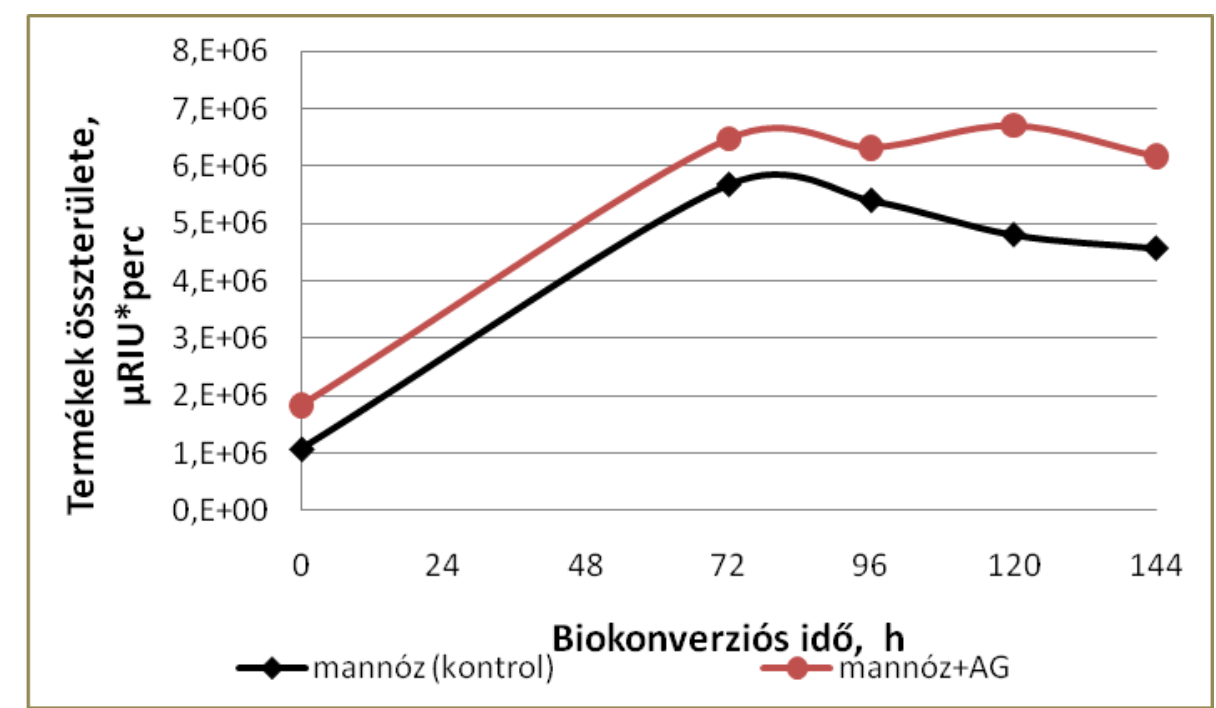

15. ábra: Az aminoguanidin hatása a mannóz alapú szénhidrát szintézisre (paraméterek: $\mathrm{pH} 5,0,70^{\circ} \mathrm{C}, 60 \mathrm{~g} / 100 \mathrm{ml}$ mannóz koncentráció, $15 \mathrm{mM} \mathrm{AG}$, detektálás: HPLC-RID technika) 
$\mathrm{Az}$ 15. ábrán a két termék kromatogram-csúcsának együttes területe látható az idő függvényében. Megfigyelhető, hogy míg a kontrol minta esetében a 72. óra után csökken a termékek mennyisége, az aminoguanidin jelenlétében kis mértékben, de tovább növekszik. Az alkalmazott Maillard inhibitorok hatását a MAITIN és RASTALL is vizsgálta (2004). Penicillium citrinum eredetü $\alpha$-mannozidáz enzim reverz hidrolízis aktivitását tanulmányozták mannóz szubsztrátumon. Az ő esetükben mindegyik inhibitor növelte a termék hozamot. A legjobb eredményt OPD alkalmazásával érték el. $10 \mathrm{mM}$ OPD tartalom 53\%-ban növelte a relatív hozamot. Az Aspergillus aculeatus eredetü enzimkészítmény aminoguanidin jelenlétében 35\%-kal növelte meg a termék hozamot (a 144. órát tekintve).

\subsubsection{A mannóz alapú di/oligoszacharidok elválasztása és jellemzése}

A mannóz alapú (di,oligo)szacharidok elválasztásához és jellemzéséhez nagyobb mennyiségü termékre volt szükségem, így léptéknövelési kísérletet hajtottam végre. Gyakorlatban az optimális körülményeket $\left(\mathrm{pH} 5,0,70{ }^{\circ} \mathrm{C}, 60 \mathrm{~g} / 100 \mathrm{ml}\right.$ mannóz koncentráció, 3,1 mg fehérje/g mannóz enzimmennyiség) alkalmazva $5 \mathrm{ml}$ térfogatban valósítottam meg egy 144 órás biokonverziót. A tisztításhoz BioGel-P2 töltetet alkalmaztam, eluensként 0,001\% Na-azidot tartalmazó desztillált vizet használtam, amelyet $0,75 \mathrm{ml} /$ perc térfogatárammal mostam át az oszlopon. A tisztítás során $2 \mathrm{ml}$ térfogatú frakciókat gyüjtöttem. A kapott frakciók szénhidrát összetételét TLC technikával vizsgáltam (16. ábra).

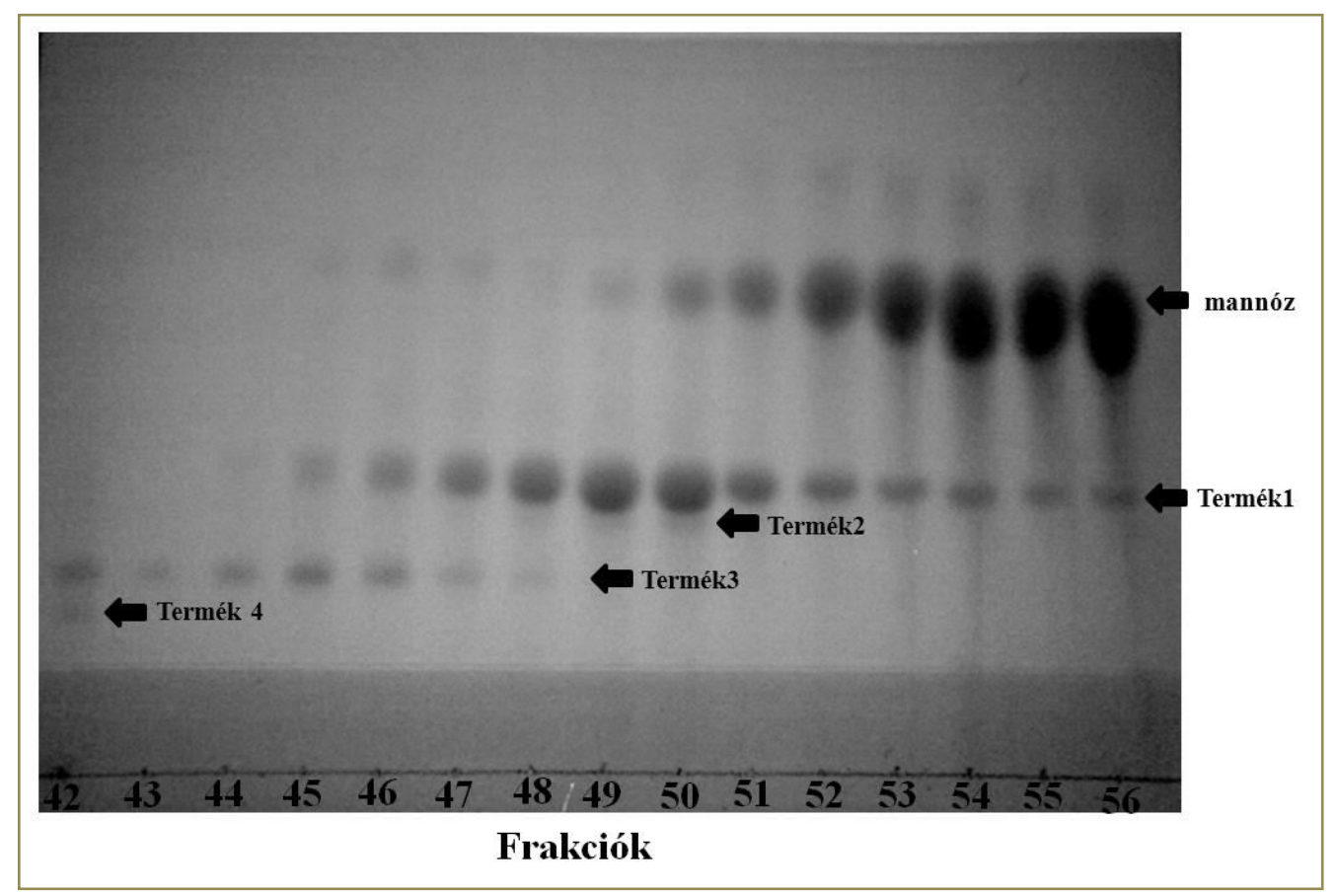

16. ábra: A mannóz alapú szénhidrátok tisztítása során kapott frakciók TLC analízissel detektált összetétele

(biokonverziós paraméterek: pH 5,0, $70{ }^{\circ} \mathrm{C}, 60$ g/100ml mannóz koncentráció, 144. óra) (tisztítás paraméterei: 78*1,8 cm BioGel-P2 oszlop, 0,75 ml/perc, $2 \mathrm{ml}$ frakció, eluens 0,001\% Na-azid ) 
A TLC analízissel 4 szintézis termék kimutatása volt lehetséges a frakciókban. Ezen kívül egyes frakciókban polimerek jelenléte volt megfigyelhető (ábrán nincs feltüntetve). Az első tisztítás során kapott frakciók szénhidrát összetétele alapján a Termék3 tisztítását tüztem ki célul. Ennek érdekében e terméket tartalmazó frakciókat összeöntöttem (az ábrán jelölt esetben a 42-48 frakciókat) és liofileztem.

Az kapott liofilizátumot visszaoldottam $1 \mathrm{ml}$ desztillált vízbe és ismét felvittem a BioGel-P2 oszlopra. A 2. tisztítási lépés során a Termék3 szénhidrátot a TLC vizsgálat alapján megfelelő tisztaságban sikerült kinyertem (17. ábra).

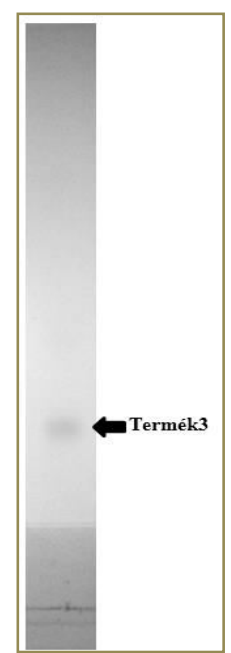

\section{7. ábra: Pectinex ultra enzimkészítménnnyel előállított tiszta mannóz alapú szintézis terméket tartalmazó oldat TLC képe \\ (biokonverziós paraméterek: $\mathrm{pH} 5,0,70{ }^{\circ} \mathrm{C}, 60 \mathrm{~g} / 100 \mathrm{ml}$ mannóz koncentráció, 144. óra) (tisztítás paraméterei: 78*1,8 cm BioGel-P2 oszlop, 0,75 ml/perc, $2 \mathrm{ml}$ frakció, eluens 0,001\% Na-azid )}

A kapott termék tisztaságát és polimerizáltságát a Debreceni Egyetem Szervetlen és Analitikai Kémiai Tanszéke ellenőrizte MALDI-TOF-MS technikával. A vizsgálat során fény derült arra, hogy a kinyert szénhidrát egy triszacharid (m/z=527,09, 18. ábra). Ez az eredmény alátámasztja, hogy Pectinex ultra rendelkezik mannozidáz aktivitással, amely segítségével különböző mannooligoszacharidok szintetizálhatók.

A 2. tisztítás során fennmaradó, termékeket tartalmazó frakciókat összeöntöttem, és szintén MALDI-TOF-MS analízisre küldtem. A 19. ábrán jól látható, hogy e módszerrel már 5 féle szénhidrát volt kimutatható. Az m/z értékek alapján dimer $(\mathrm{m} / \mathrm{z}=345,12 ; \mathrm{m} / \mathrm{z}=362)$, trimer $(\mathrm{m} / \mathrm{z}=527,18 ; \mathrm{m} / \mathrm{z}=543,12)$, tetramer $(\mathrm{m} / \mathrm{z}=689,16)$, pentamer $(\mathrm{m} / \mathrm{z}=867,18)$, hexamer $(\mathrm{m} / \mathrm{z}=1029)$ termékek keletkeztek a reakció során. Ez új eredménynek mondható, ugyanis eddigi tanumányokban mannóz alapú reverz hidrolízis esetében csak mannobióz, mannotrióz és mannotetraóz szintéziséről számoltak be (AJISAKA et al., 1995; SUWASONO \& RASTALL, 1996; Singh et al., 2000; ATHANASOPOULOS et al., 2004; MAITIN et al., 2004). 
COUTURIER és munkatársai (2013) $\beta$-mannanáz enzim transzmannozidáz aktivitásának felhasználásával $\beta$-kötésű manno-oligoszacharidokat szintetizáltak manno-pentaóz szubsztrátum alkalmazásával. A következő termékeket detektáltálták: M2, m/z 365.1; M3, m/z 527.1; M4, m/z 689.2; M5, m/z 851.2; M6, m/z 1013.3, M7, m/z 1175.3; M8, m/z 1337.3.

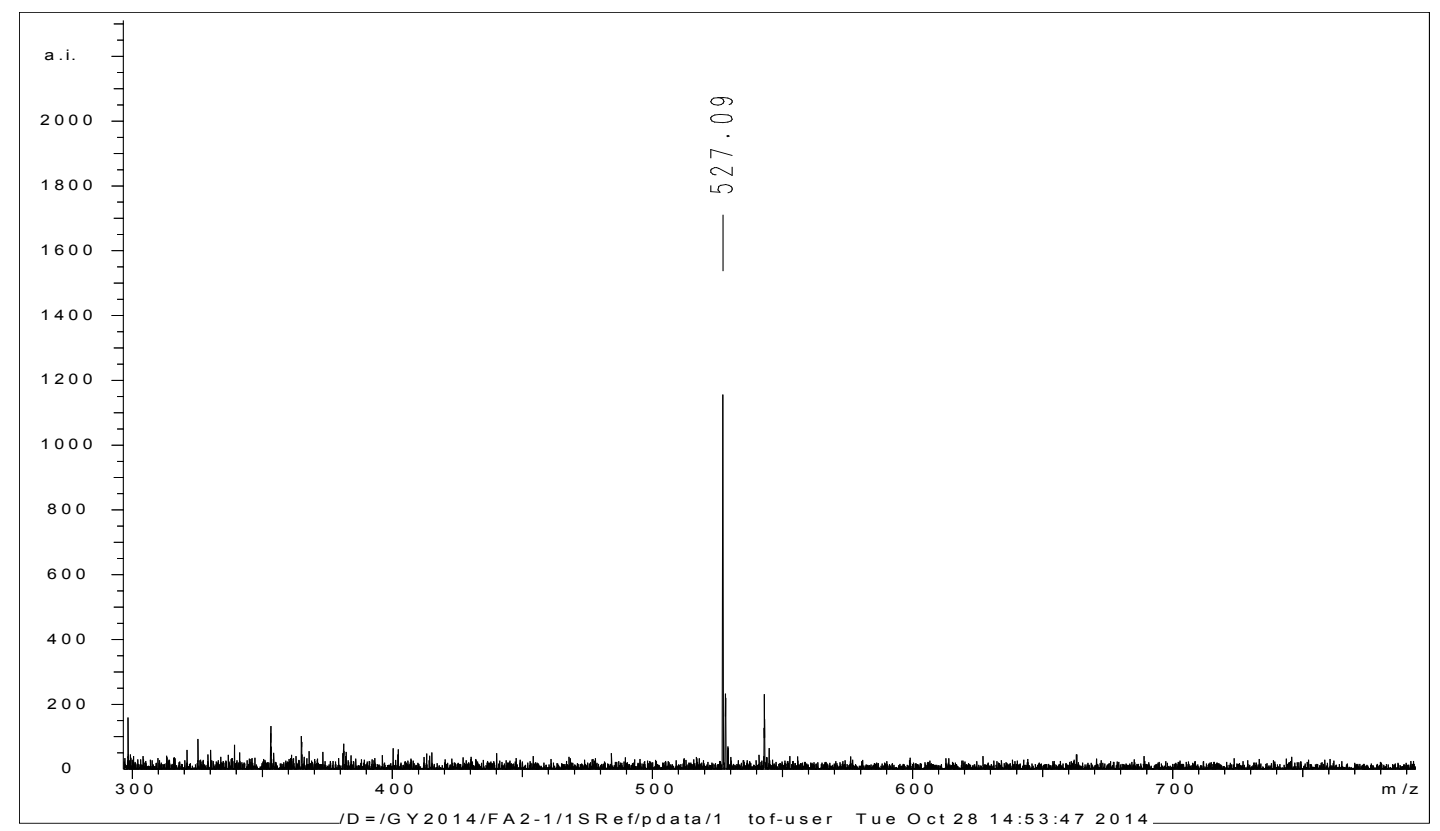

18. ábra: A BioGel-P2 oszloppal történő tisztítással kinyert Pectinex ultra-val szintetizált mannotrióz MALDI-TOF-MS spektruma

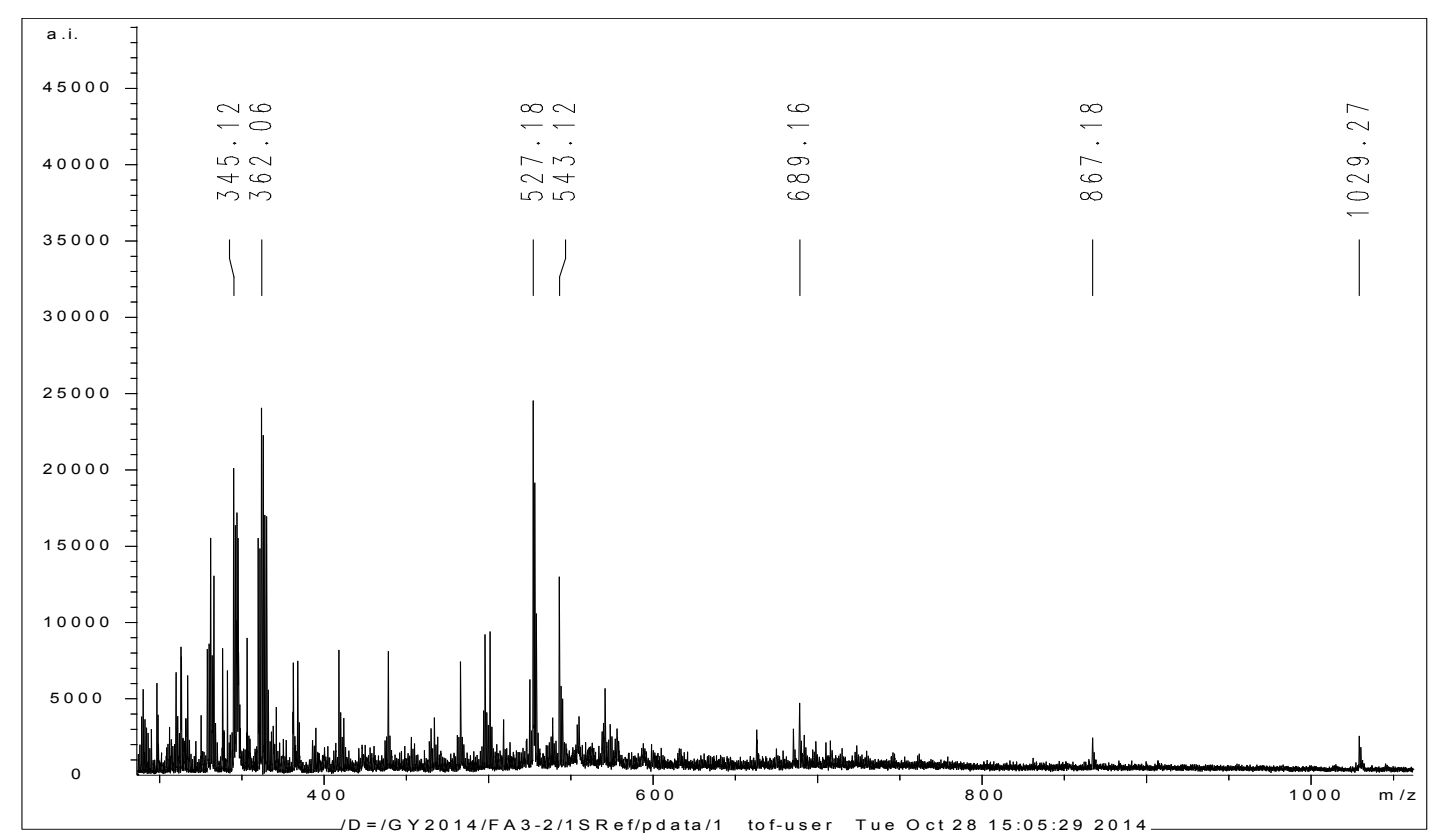

19. ábra: A Pectinex ultra enzimkészítménnyel mannózon szintetizált termékek MALDI-TOF-MS spektruma

Esetemben vélhetően $\alpha$-glikozidos kötéssel kapcsolódnak a mannóz egységek, mivel eddigi tanulmányokban csak az $\alpha$-mannozidáz enzim reverz hidrolízis reakciójáról számoltak be 
mannóz szubsztrátumon.Vannak olyan $\alpha$-mannozidázok, amelyek a reverz hidrolízis révén csak egyféle kötéstípus kialakítására képesek. Ilyen például az ATHANASOPOULOS és munkatársai (2004) által tanulmányozott $\alpha$-mannozidáz, amely csak $\alpha(1-6)$ kötésű termékeket eredményezett. SUWASONO és RASTALl (1996) pedig egy $\alpha(1-2)$ kötésre specifikus (Aspergillus niger eredetü) a-mannozidáz enzimről számoltak be. Emellett kis régiospecifitással rendelkező a-mannozidázokról is jelent meg tanulmány (AJISAKA et al., 1995; SINGH et al., 2000). E nem specifikus $\alpha$-mannozidázok háromféle kötéstípus kialakítására képesek: $\alpha(1-2), \alpha(1-3), \alpha(1-6)$.

Az általam alkalmazott $\alpha$-mannozidáz régiospecifitásának jellemzéséhez további vizsgálatokra (NMR) van szükség.

\subsection{Oligoszacharid szintézis biszubsztrátumú rendszerekben}

\subsubsection{Reverz hidrolizis Pectinex ultra enzimkészítménnyel}

A doktori kutatásomban az oligoszacharid szintézist különböző monoszacharidokat tartalmazó biszubsztrátum rendszerekben is megvizsgáltam. E két-szubsztrátumos rendszerek mannózt és különböző monoszacharidokat(arabinóz, fruktóz, glükóz, szorbóz és xilóz) tartalmaztak 2:1 arányban. A reakciókörülményeket a korábban meghatározott $\alpha$-mannozidáz enzim által katalizált reverz hidrolízis reakció optimum paramétereire állítottam be. Kontrol vizsgálatokat is végeztem, amelyekben monoszubsztrátumokkal indítottam reakciót. A biokonverzió különböző időpontjaiban vettem a mintákat és analizáltam. A 20. ábrán a 96. órában kapott hozamokat (dimer és oligomerek együttesen) hasonlítottam össze.

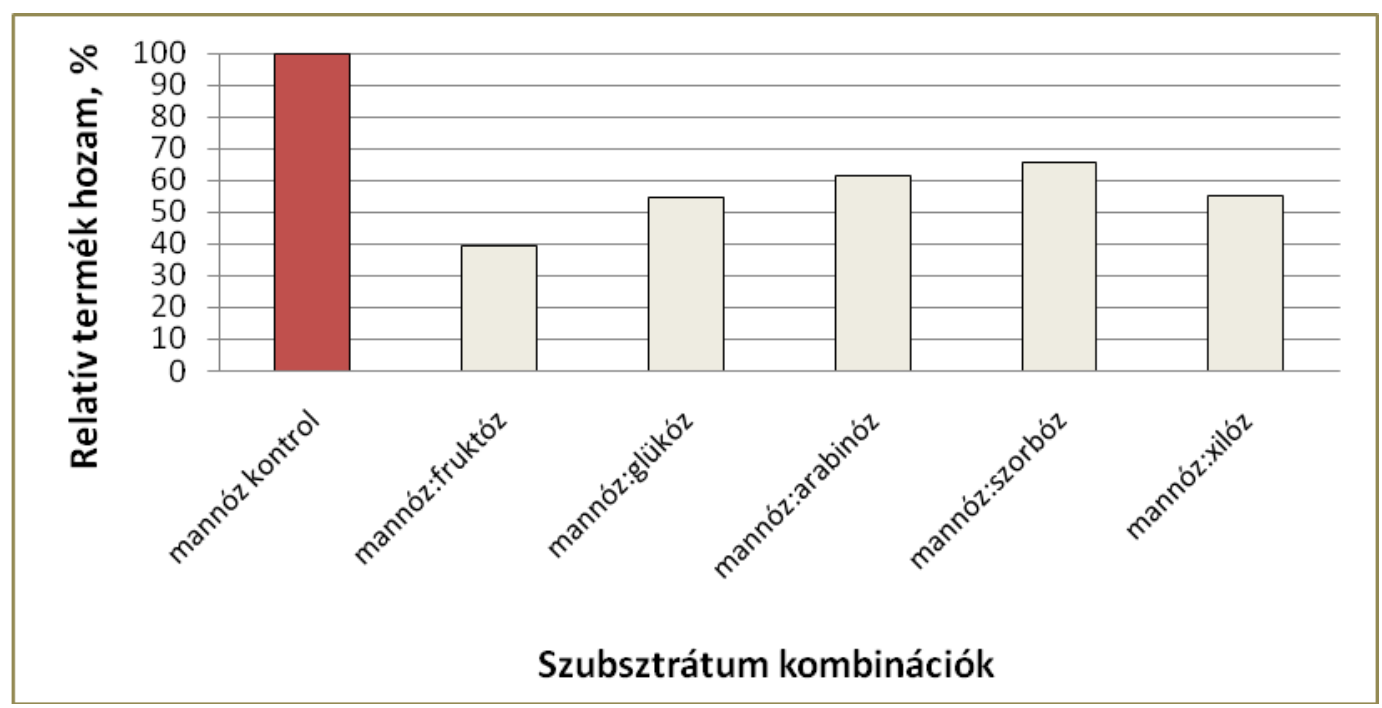

20. ábra: A Pectinex ultra által katalizált reverz hidrolízis termékeinek relatív hozama különböző biszubsztrátumokon

(paraméterek: , pH 5,0, $70{ }^{\circ} \mathrm{C}, 60 \mathrm{~g} / 100 \mathrm{ml}$ szubsztrátum koncentráció, szubsztrátum arány 2:1,96. óra, detektálás: HPLC-RID technika) 
Megállapítottam, hogy a mannóz:fruktóz, mannóz:glükóz, mannóz:arabinóz, mannóz:szorbóz és mannóz:xilóz kombinációk a tiszta mannóz szubsztrátumon elért oligomer hozam csupán 39\%-át (mannóz:fruktóz), 54\%-át (mannóz:glükóz), 61\%-át (mannóz:arabinóz), 65\%-át (mannóz:szorbóz) és 55\%-át (mannóz:xilóz) eredményezték. Tekintve, hogy a mannóz 1/3-ad részét helyettesítettem más monoszachariddal, feltételeztem, hogy a kontrol minta hozamának minimum 2/3-át elérem a készítmény $\alpha$-mannozidáz enzime által katalizált reverz hidrolízis reakciónak köszönhetően. Eredményeim alapján azonban az feltételezhető, hogy a Pectinex ultra mannozidáz enzime nagyfokú specifitást mutat a mannóz szubsztrátum felé, ezért nem volt képes olyan reverz hidrolízis reakciót katalizálni, melyben a mannózon kívül más monoszacharid is részt vesz. Ezt megerősítette a TLC vizsgálat eredménye is, mellyel nem volt megfigyelhető a mannóz alapú termékektől eltérő retenciójú szénhidrát jelenléte. Eredményeim alapján az is megfigyelhető, hogy a fruktóz gátolja az $\alpha$-mannozidáz müködését. Az alacsony termék hozam oka lehet, hogy a fruktóz negatívan befolyásolja az enzim stabilitását. MALÁ és KRÁLOVÁ (2000) Bacillus stearothermophilus eredetű $\alpha$-glükozidáz (által katalizált reverz hidrolízis) vizsgálatánál a mannóz és a xilóz kedvezőtlen hatását mutatták ki az enzim stabilitására.

Érdekes eredmény, hogy glükóz:mannóz biszubsztrátum esetén a vártnál kisebb termékszintézis (54\%) detektálható, tekintve, hogy monoszubsztrátumként mindkét szubsztrátumon kimutatható volt termékképzés (4.1.2 fejezet). Egyes $\alpha$-glükozidáz és $\alpha$-mannozidáz enzimek esetében lehetséges oligoszacharidok előállítása biszubsztrátum rendszerek alkalmazásával. RASTALL és munkatársai (1992) különböző biszubsztrátum rendszereket vizsgáltak a Canavalia ensiformis babfajta eredetű $\alpha$-mannozidázzal. Azt tapasztalták, hogy 50:50 arányban mannózt és arabinózt tartalmazó 45\% szénhidrát koncentrációjú közegben akár 145\% oligomer hozam is elérhető, a monoszubsztrátum rendszerekhez viszonyítva. Talán az a különbség, hogy ebben az esetben növényi eredetű mannozidázt alkalmaztak, amelyek általában aktívabbak a szintézis vagy transzfer reakciók irányába. Mikrobiális mannozidáz ilyen aktivitásáról nem találtam adatokat a szakirodalomban.

Multiszubsztrátum alapú reverz hidrolízissel történő oligoszacharid szintézisről PESTLIN és munkatársai (1997) is beszámoltak. Ök az Aspergillus niger eredetü glükoamilázról bizonyították, hogy képes oligoszacharidokat szintetizálni arabinóz/fruktóz/galaktóz/mioinozit/lixóz/mannóz/ribóz/xilóz és glükóz szubsztrátumok részvételével. MALÁ és KRÁLOVÁ (2000) pedig Bacillus stearothermophilus eredetű $\alpha$-glükozidáz enzimet vizsgáltak biszubsztrátum rendszerekben és azt tapasztalták, hogy a xilóz és a mannóz lehetséges akceptorok a reverz hidrolízis reakcióban. 


\subsubsection{Transzglikoziláció Pectinex ultra enzimkészítménnyel}

\subsubsection{Különböző szubsztrátum kombinációk}

Korábbi tanulmányokban bizonyításra került, hogy a Pectinex ultra enzimkészítmény nagymértékü $\beta$-galaktozidáz és fruktoziltraszferáz aktivitással rendelkezik, amelyet aktivitásmérési eredményeim is alátámasztottak (10. táblázat). Célom volt a traszglikoziláció biszubsztrátum rendszerben történő tanulmányozását e két aktivitásra fókuszálva megvalósítani, ezért a laktózt és a szacharózt különböző szénhidrátokkal (mono- és diszacharidokkal: fruktóz, galaktóz, glükóz, laktóz, maltóz, mannóz, szacharóz, xilóz) együtt alkalmazva hoztam létre biszubsztrátumos rendszereket. A reakció közegek 10 g/100ml koncentrációban tartalmaztak szénhidrátot, a szubsztrátumok 1:1 arányú jelenlétével. Eredményeimet a 21. ábra mutatja.

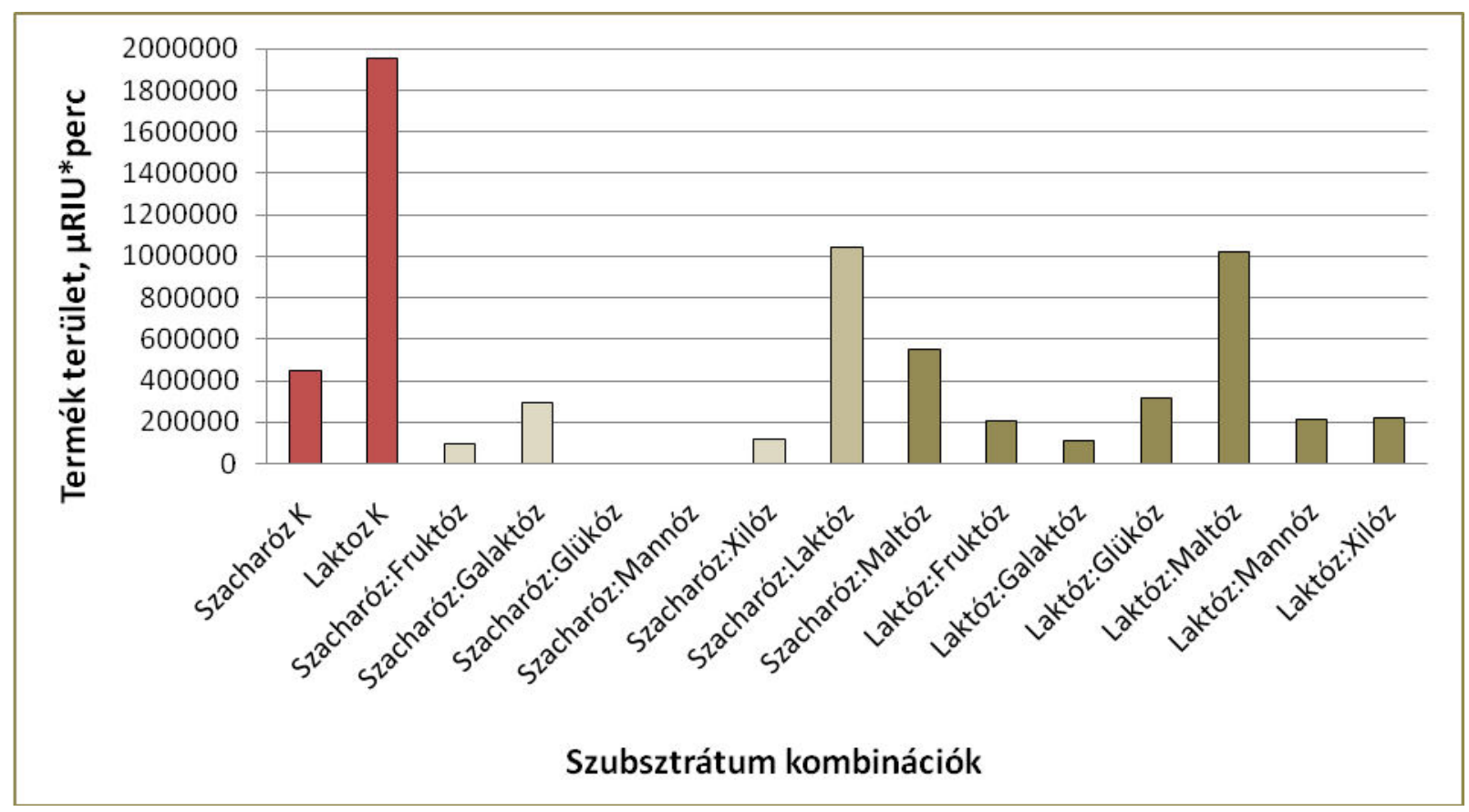

\section{1. ábra: A Pectiney ultra által katalizált transzglikozilációs reakciók termékeinek mennyisége különböző biszubsztrátum rendszerekben}

(paraméterek: pH 5,5, $60{ }^{\circ} \mathrm{C}, 10 \mathrm{~g} / 100 \mathrm{ml}$ szénhidrát tartalom, 1:1 arány, 96. óra, detektálás: HPLC-RID technika)

A kapott eredmények alapján megállapítható, azon kombinációk esetén, amelyekben a szacharózt vagy a laktózt monoszacharidokkal (glükóz, fruktóz, mannóz és xilóz) alkalmaztam együtt nem, vagy csak mininális oligoszacharid hozamot eredményeztek. A glükóz, mint a frukto-oligoszacharid előállítás melléktermékének, gátló hatásáról már számos tanulmány beszámolt (DUAN et al., 1994; SHEU et al., 2001). Továbbá a $\beta$-galaktozidáz enzimmel történő galakto-oligoszacharid előállítás során melléktermékként keletkező monoszacharidok (glükóz, galaktóz) transzglikozilációs reakcióra kifejtett gátló hatását is bizonyították már (NERI et al., 2009; AlbAYRAK \& YANG, 2002, KIM et al., 2001). Érdekesnek tartom azonban, hogy a 
szacharóz:mannóz és szacharóz:glükóz biszubsztrátmok esetén nem detektáltam termékképzést. Egy korábbi (4.1.2) fejezetben ugyanis bizonyítottam, hogy a Pectinex ultra enzimkészítmény képes reverz hidrolízis reakciót katalizálni e két monoszacharidon. Ebből arra következtetetek, hogy nem csak a glükóz és a mannóz gátolja a transzfruktozilációs reakció végbemenetelét, hanem a szacharóz is gátolja a mannózon illetve glükózon történő reverz hidrolízist.

Jobb eredmények érhetők el diszacharid szubsztrátumok alkalmazásával. Mind a laktóz:maltóz, mind a szacharóz:laktóz és mind a szacharóz:maltóz kombinációval kiemelkedő eredményt értem el.

A szacharóz és laktóz kombinációnál a laktóz kontrol a 45\%-át, a szacharóz kontrolnak pedig 233\%-át (termék terület: $1044021 \mu \mathrm{RIU}{ }^{*}$ perc) értem el. Itt a szacharóz konrolhoz mért nagy hozam vélhetően annak köszönhető, hogy a Pectinex ultra enzimkészítményben lévő $\beta$-galaktozidáz és fruktoziltranszferáz enzimek párhuzamos müködése ment végbe. A szacharóz kontrolhoz képest mért magas hozam azonban felveti a lehetőségét más szintézis utaknak. E biszubszrátum alkalmazásával már ipari méretekben állítanak elő egy bifidogén hatású oligoszacharidot, a laktószacharózt (Ensuiko Sugar Refining Co., Hayashibara Shoji Inc.; Japán), melynek alapja, hogy a $\beta$-fruktofuranozidáz enzim a szacharóz fruktóz részét a laktózra szállítja (CRITTENDEN\&Playne, 1996). SEO és munkatársai (2007) pedig egy olyan enzimes reakcióról számoltak be, amelyben a szacharóz glükóz részét vitték át a laktóz molekulára. Ezt a Leuconostoc citreum eredetü dextránszukráz enzimmel valósították meg, a szintetizált oligoszacharid pedig 6-glükózil-laktóz volt.

Szacharóz és laktóz biszubsztrátum rendszert Li és munkatársai (2009) is vizsgálták a Bacillus circulans eredetű $\beta$-galaktozidáz enzim transzgalaktozilációs reakciója esetében. Megállapították, hogy a vizsgált $\beta$-galaktozidáz enzim a laktóz (donor) szubsztrátumról galaktóz egység átvitelét katalizálta szacharóz (akceptor) molekulára különböző oligoszacharidokat szintetizálva.

A szacharóz:maltóz (termék terület: $547341 \mu \mathrm{RIU} *$ perc) és a laktóz:maltóz (termék terület: $1019156 \mu$ RIU*perc) együttes alkalmazásával is kiemelkedő eredményt értem el a kontrol minták esetében elért oligoszachrid tartalomhoz képest. E biszubsztrátumok esetében is felvetődik a kérdés, vajon a nagy oligoszacharid tartalom több enzim párhuzamos müködésének (szacharóz:maltóz esetében az fruktoziltranszferáz:a-glükozidáz, laktóz:maltóz esetében a $\beta$-galaktozidáz: $\alpha$-glükozidáz) vagy egy enzim képes többféle diszacharidot akceptorként felismerni. Ennek megállapítására a három kiemelkedő eredményt mutató biszubsztrátum rendszert TLC módszerrel is megvizsgáltam. A kapott eredményeket a 22. ábra szemlélteti. 


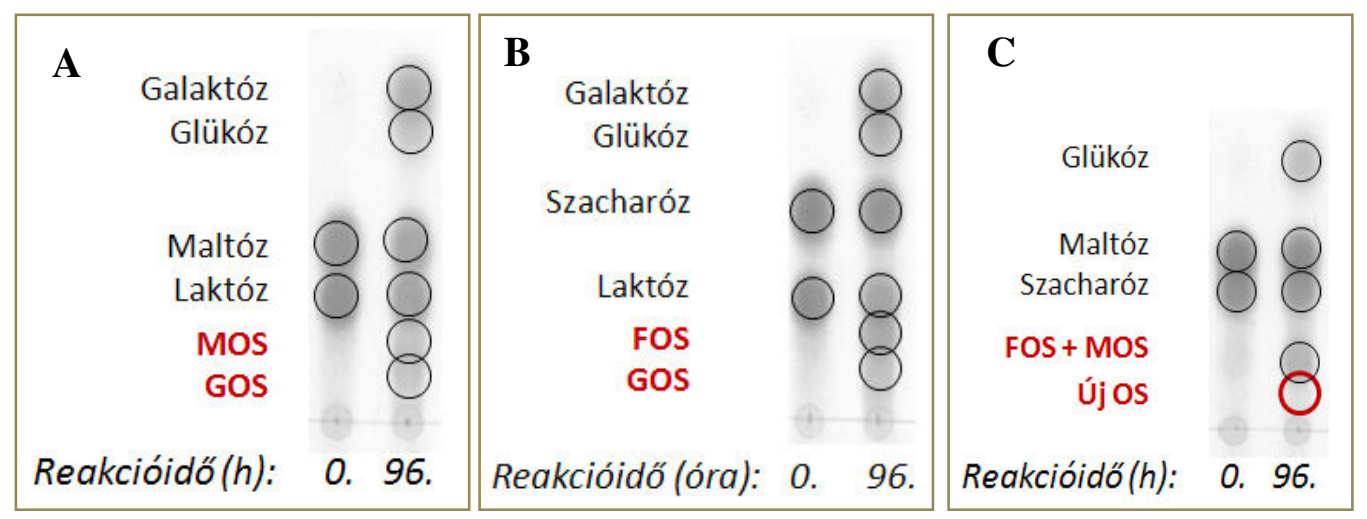

22. ábra: Laktóz:Maltóz (A), Szacharóz:Laktóz (B) és Szacharóz:Maltóz biszubsztrátumon Pectinex ultra enzimkészítménnyel végzett biokonverzió TLC képe (paraméterek: $\mathrm{pH} 5,5,60^{\circ} \mathrm{C}, 10 \mathrm{~g} / 100 \mathrm{ml}$ szubsztrátum koncentráció, $1: 1$ arány,96. óra) MOS: malto-oligoszacharid, GOS: galakto-oligoszacharid, FOS: frukto-oligoszachrid

A TLC vizsgálat eredményei azt mutatták, hogy a laktóz:maltóz (22.A. ábra) esetén egy galaktooligoszacharid és egy malto-oligoszacharid retenciójával megegyező oligoszacharid szintetizálódott a készítményben lévő fruktoziltranszferáz és a $\beta$-galaktozidáz enzim együttes müködése révén. A szacharóz:laktóz (22.B. ábra) esetében frukto-oligoszacharidok és galaktooligoszacharidok retenciójával megegyező termékek keletkeztek a fruktoziltranszferáz és a $\beta$-galaktozidáz enzim által katalizált transzglikozilációs reakcióknak köszönhetően. Egyik esetben sem mutatható ki új oligoszacharid képződése. Szacharóz:maltóz kombináció esetében azonban egy eltérő retencióval rendelkező terméket detektáltam (22.C. ábra; STYEVKó et al., 2013). A HPLC-RID vizsgálatok alapján megállapítható, hogy az új oligoszacharid trimer, amelynek szintézise 3 féle úton mehetett végbe:

a) a készítmény $\alpha$-glükozidáz enzimének köszönhetően transzglükoziláció ment végbe, amelyben a maltóz mint donor, a szacharóz mint akceptor molekula vett részt, így szintetizálva glükozil-szacharózt,

b) vagy transzglükoziláció ment végbe, amelyben a szacharóz mint donor, a maltóz mint akceptor molekula vett részt, így szintetizáltva glükozil-maltózt

c) vagy az fruktoziltranszferáz enzimének köszönhetően transzfrukozilációs reakció ment végbe, amelyben a szacharóz mint donor, a maltóz mint akceptor molekula vett részt, fruktozil-maltózt szintetizálva.

Korábbi tanulmányokban már számoltak be szacharóz és maltóz együttes alkalmazásáról. CANEDO és munkatársai korábban (1999) Bacillus subtilis eredetű levánszukráz felhasználásával olyan transzfruktozilációs reakciót végeztek, amelyben a szacharóz donorként, a maltóz akceptor molekulaként szerepelt. Ennek köszönhetően maltozil-fruktózt (erlózt) szintetizáltak.

Transzglükozilációs reakcióról is számoltak be korábban e biszubsztrátum kombináció esetében (CRittenden \& Playne, 1996; Dols et al., 1999; Demuth et al., 2002; Helmuth et al., 2008). 
A glükozil-szacharóz szintézise is e két szubsztrátum együttes alkalmazásával történik, mely már egy kereskedelmi forgalomban kapható szénhidrát (CRITTENDEN \& PLAYNE, 1996). E szénhidrát előállítása a ciklomaltodextrin-glükanotranszferáz enzimmel történik, mely a maltózról glükóz egységet szállít a szacharóz molekulára. HEINCKE és munkatársai (1999) a Leuconostoc mesenteroides NRRLB-512 F eredetü dextránszukráz enzim transzglükozilációs reakcióját tanulmányozták és kimutatatták, hogy az enzim olyan reakciót katalizál, amelyben a szacharóz glükózil-donorként, a maltóz pedig akceptor molekulaként vesz rész. Később ezt megerősítették további akceptor molekulák vizsgálata mellett is (DEMUTH et al., 2002). HELMUTH és munkatársai 2008-ban (2008) a Streptococcus oralis eredetű glükánszukráz enzim régiospecifitását és akceptor specifitását változtatták meg mutagenézis segítségével. Esetükben is a szacharóz volt a donor molekula, melyet sikeresen alkalmaztak különböző akceptor szénhidrátokkal.

\subsubsection{Szacharóz:maltóz arány hatása az oligoszacharid szintézisre}

Általánosan elfogadott tény, hogy az oligoszacharid hozam növelhető a donor:akceptor arány optimálásával. Az optimális arányt nagyban meghatározza az alkalmazott enzim eredete illetve a transzfer reakcióban részt vevő donor és akceptor molekulák összetétele (MAITIN \& RASTALL, 2007). A fent említett eredmények alapján a szacharóz és a maltóz különböző arányú kombinációinak az oligoszacharid szintézisre gyakorolt hatását vizsgáltam. A biokonverziót pH 5,5 és $60{ }^{\circ} \mathrm{C}$ körülmények között hajtottam végre 20 g/100ml szubsztrátum koncentrációval.

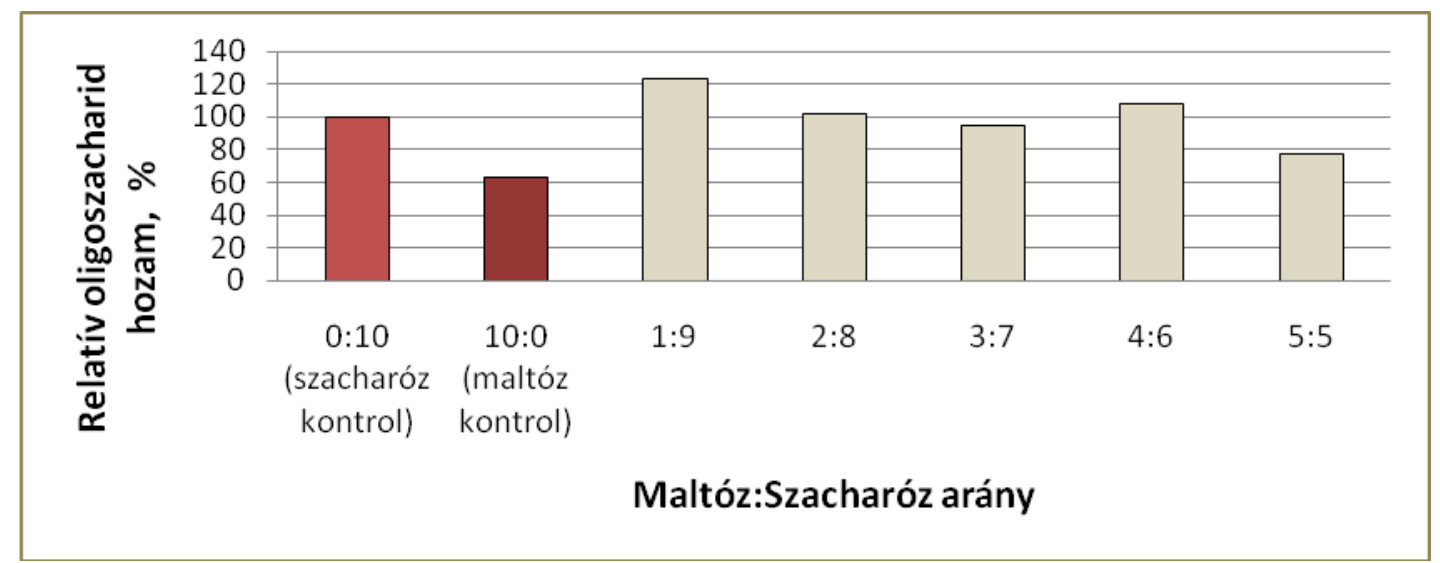

\section{3. ábra: Relatív oligoszacharid hozamok a Pectinex ultra által katalizált transzglikozilációs reakció 24. órájában,a szacharóz és maltóz különböző arányai esetében \\ (paraméterek: pH 5,5, $60^{\circ} \mathrm{C}, 20 \mathrm{~g} / 100 \mathrm{ml}$ szubsztrátum koncentráció, detektálás: HPLC-RID technika)}

A kapott eredményeket a 23. ábra mutatja. Jól látható, hogy a legkisebb oligoszacharid hozamot (a szacharóz kontrol 60\%-át) maltóz monoszubsztrátum esetén kaptam, a legmagasabbat pedig 1:9 arányú maltóz:szacharóz kombinációnál (STYEVKó et al., 2013). Az eredményem egyezik 
CANEDO és munkatársai (1999) által vizsgált levanszukráz enzim optimális maltóz:szacharóz arányával. Megjegyzem, hogy a 4:6 arányú összetétel (maltóz:szacharóz) is jó eredményt mutatott (108\%).

\subsubsection{Szubsztrátum koncentráció hatása az oligoszacharid szintézisre}

Az optimális szubsztrátum koncentráció meghatározására 20 - 70 g/100 ml tartományban vizsgáltam a biokonverziót. Az előző kísérletben elért eredmények alapján a maltóz:szacharóz 1:9 arányú összetételét alkalmaztam. Az oligoszacharid szintézist 192 óráig vizsgáltam pH 5,5 és $60{ }^{\circ} \mathrm{C}$ paraméterek mellett.

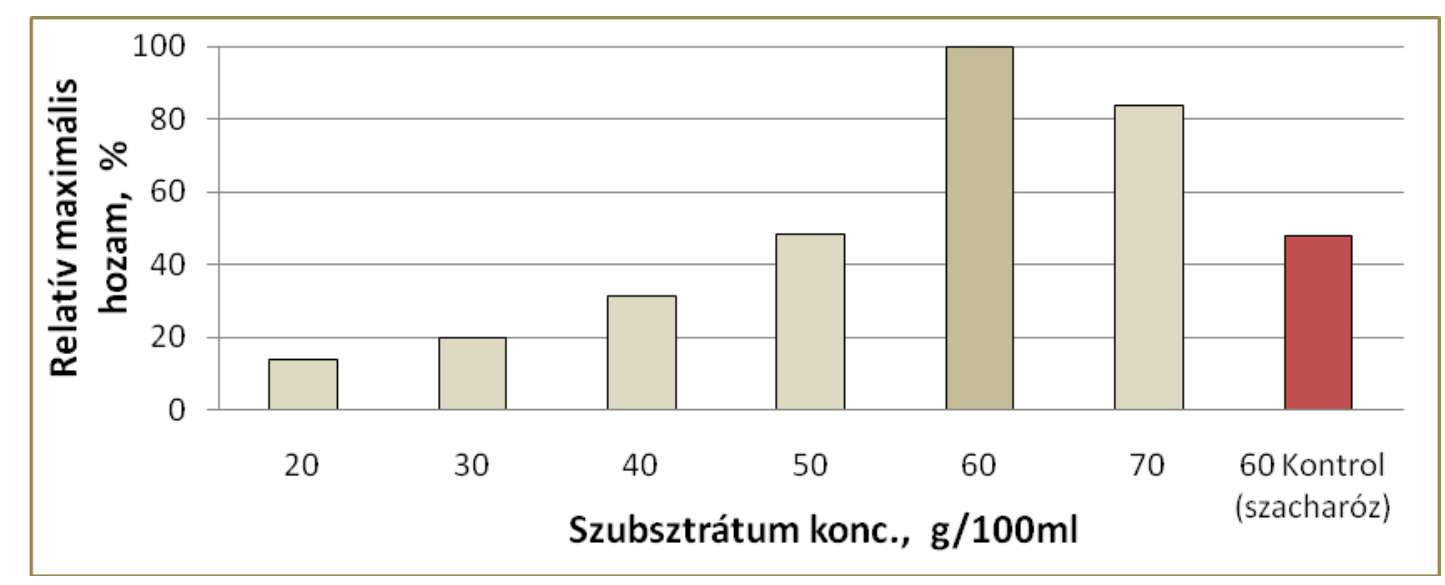

24. ábra: Relatív oligoszacharid hozamok a Pectinex ultra által a maltóz:szacharóz biszubsztrátumon katalizált transzglikozilációs reakció során, különböző szubsztrátum koncentrációk esetében

(paraméterek: pH 5,5, $60{ }^{\circ} \mathrm{C}, 192$ óra, maltóz:szacharóz arány 1:9, detektálás: HPLC-RID technika)

A 24. ábrán megfigyelhető, hogy a maltóz és szacharóz együttes alkalmazása esetén a szubsztrátum koncentráció növelése fokozza az oligoszacharid hozamát. A maximális hozamot a 60 g/100 ml szubsztrátum koncentrációnál mértem, azután csökkent (STYEVKÓ et al., 2013). Összevetve az előző fejezetben kapott eredménnyel, azt tapasztaltam, hogy az enzim kb. ötszörösen több oligoszacharidot szintetizált ebben az esetben, mint a 20g/100 ml szubsztrátum koncentráció esetén. Az eredményeim megegyeztek HANG és WoODAMS (1996) által közöltekkel. Az Aspergillus foetidus, Aspergillus niger és Aureobasidium pullulans eredetü fruktoziltranszferázok optimális szubsztrátum koncentrációja szintén 55 - 60 g/100ml intervallumban található. GHAZI és munkatársai (2007) tisztították a Pectinex ultra készítményben található fruktoziltranszferáz enzimet és szacharóz esetében vizsgálták a szubsztrátum koncentráció transzfer reakcióra gyakorolt hatását. Az ő esetükben szintén $60 \mathrm{~g} / 100 \mathrm{ml}$ körüli volt az optimum.

Érdekes eredménynek tartom, hogy a 60 g/100 ml biszubsztrátum koncentrációnál a 1:9 arányú maltóz:szacharóz kombináció esetén hozzávetőlegesen kétszeres oligoszacharid hozamot értem 
el a szacharóz kontrolhoz képest. Továbbá, csupán maltóz monoszubsztrátum alkalmazásánál 60 g/100ml koncentrációban nem volt detektálható oligoszacharid képzés. Ebből arra következtettük, hogy ilyen maltóz koncentráció már gátolta a Pectinex a-glükozidázának transzglükozilációs reakcióját. Így feltételezem, hogy $60 \mathrm{~g} / 100 \mathrm{ml}$ szénhidrát tartalom és a 1:9 szubsztrátum arány alkalmazásánál csupán transzfruktoziláció ment végbe, azaz a Pectinex ultra fruktoziltranszferáz enzime a szacharóz molekulákról fruktóz molekulát visz át maltóz és szacharóz molekulákra. A reakció során két féle termék képződhet: FOS és fruktozil-maltóz.

\subsubsection{Transzglikoziláció Bacillus megaterium eredetü levánszukráz enzimmel}

Kutatómunkámban a Bacillus megaterium eredetü levánszukrázt is vizsgáltam biszubsztrátum rendszerekben. Korábban a Branschweigi Müszaki Egyetem kutatócsoportja bizonyította, hogy ez az enzim a szacharóz mellett más szénhidrátokat is felismerhet akceptorként. Képes fruktóz egység átvitelére különböző monoszacharidokra, mannózra, galaktózra, xilózra és fukózra, és így különböző szacharóz analógok elöállítására (HOMANN, 2009). ZWERENZ 2011-ben ezt kiegészítve megállapította, hogy az enzim képes a galakturonsavat és palatinózt is akceptorként felismerni.

Kutatásom célja volt az enzim további lehetséges akceptorainak feltérképezése. Ennek megvalósítására a szacharózt két diszachariddal; maltózzal és laktózzal; kombináltam,kétféle szubsztrátum koncentrációt $(30,75 \mathrm{~g} / 100 \mathrm{ml}, 61,5 \mathrm{~g} / 100 \mathrm{ml})$ és két szubsztrátum arányt (2:1 és 1:2) alkalmazva.

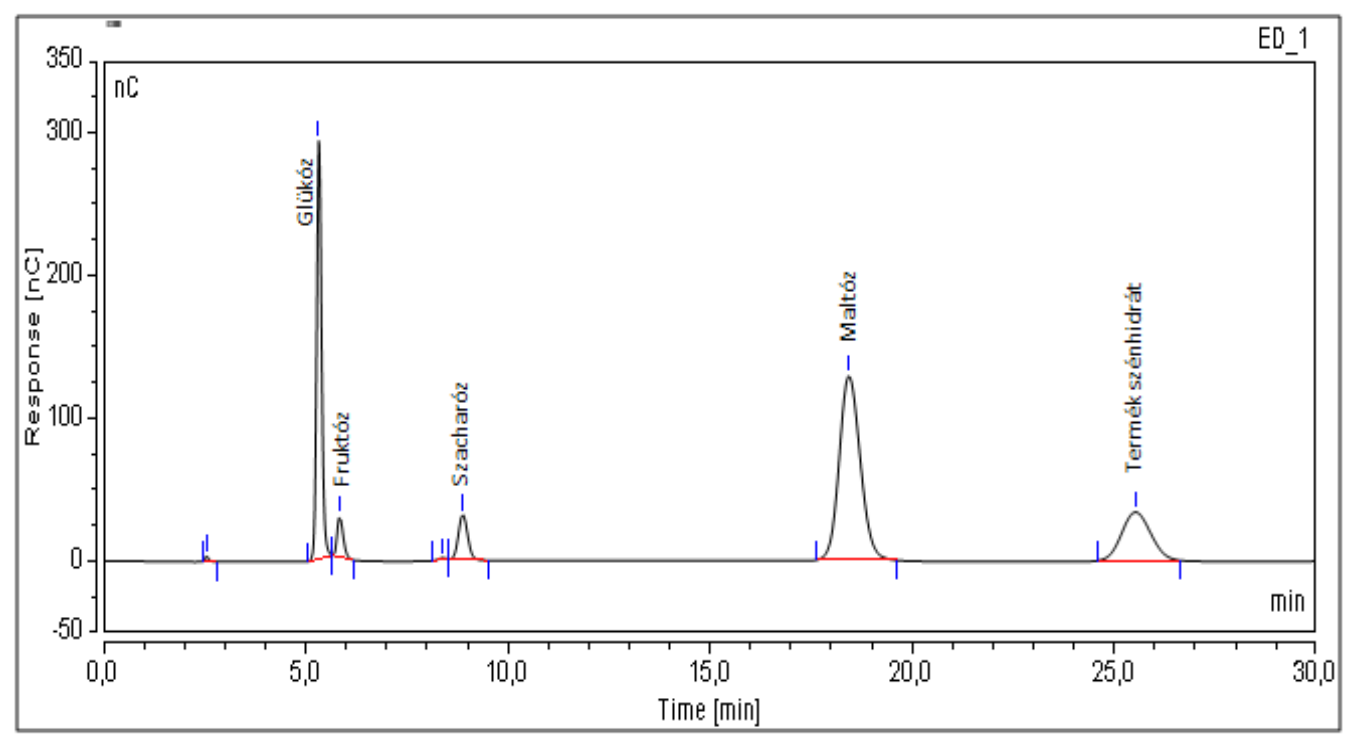

25. ábra: Szénhidrát összetétel a Bacillus megaterium eredetű levánszukrázzal, szacharóz:maltóz biszubsztrátumon végrehajtott biokonvezió 90. percében (paraméterek: $\mathrm{pH} 6,6,37^{\circ} \mathrm{C}, 61,5 \mathrm{~g} / 100 \mathrm{ml}$ szubsztrátum koncentráció, szacharóz:maltóz arány 2:1, detektálás: HPAEC-PAD technika) 
A szacharóz:maltóz biszubsztrátum esetén a HPAEC-PAD technikával egy 25,7 perces retenciójú csúcsot detektáltam (25. ábra) a biokonverzió 90. percében. E termék retenciója eltér a szacharóz monoszubsztrátum esetén szintetizált termék csúcsának megjelenésétől (17,9 perc és 18,9 perc).

Továbbá a reakció során a maltóz mennyiségének csökkenése is tapasztalható volt, tehát részt vesz a katalízisben. Ez alapján elmondható, hogy e két diszacharidot együtt alkalmazva egy eltérő szerkezetü oligoszacharid termék szintetizálható. A hidrolízis termékek közül a glükóz nagyobb mennyiségben keletkezett, amely alátámasztja, hogy a levánszukráz enzim által katalizált transzfruktoziláció ment végbe.

Termék mennyiségének alakulását elemezve azt tapasztalhatm, hogy minden általam vizsgált szubsztrátum koncentrációnál és aránynál a biokonverzió 90. percében mérhető a legnagyobb oligoszacharid koncentráció. Továbbá megállapítható, hogy a 61,5g/100ml szuszbsztrátum koncentráció és a szacharóz:maltóz 2:1 arányának alkalmazása a legkedvezőbb azoligoszacharid szintézis tekintetében (26. ábra).

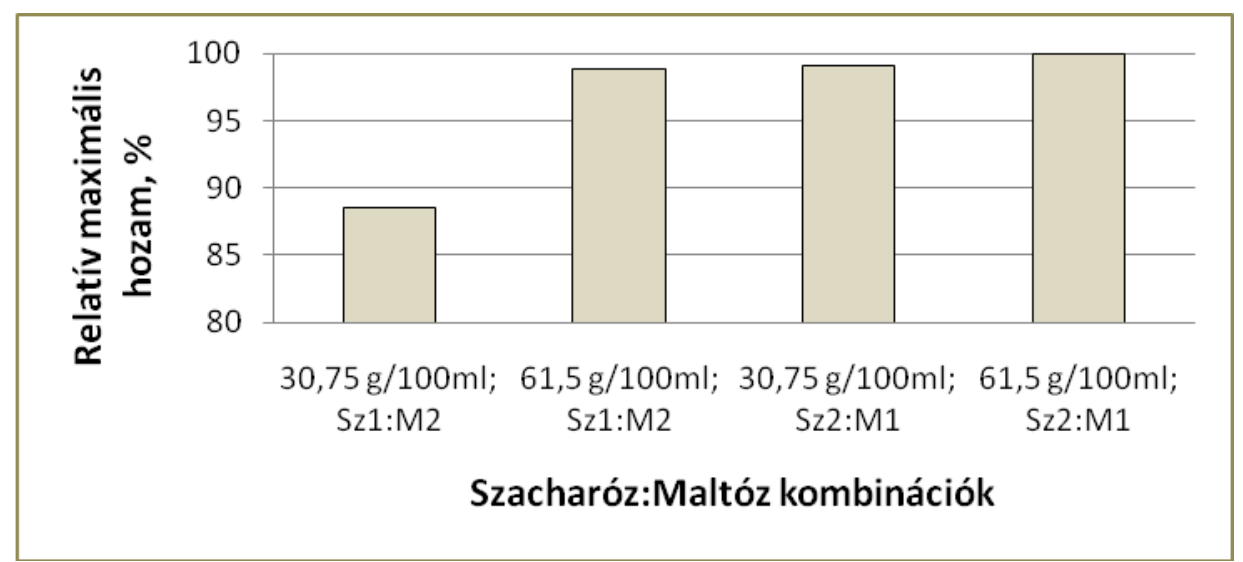

\section{6. ábra: A szacharóz:maltóz arányának hatása a Bacillus megaterium eredetű levánszukráz transzglikozilációs aktivitására (paraméterek: pH 6,6, $37^{\circ} \mathrm{C}, 4$ óra, detektálás: HPAEC-PAD technika) Sz: szacharóz, M: maltóz}

A 27. ábrán látható, hogy szacharóz laktózzal történő kombinálásával egy fő termék és két kis koncentrációban megjelenő termék szintézise volt megfigyelhető (15, 17,2 és 18,5 perces retenciós idővel a kromatogramon). A fő termék retenciója 15 perc, amely eltér a szacharóz monoszubsztrátumon detektált termék retenciójától. 


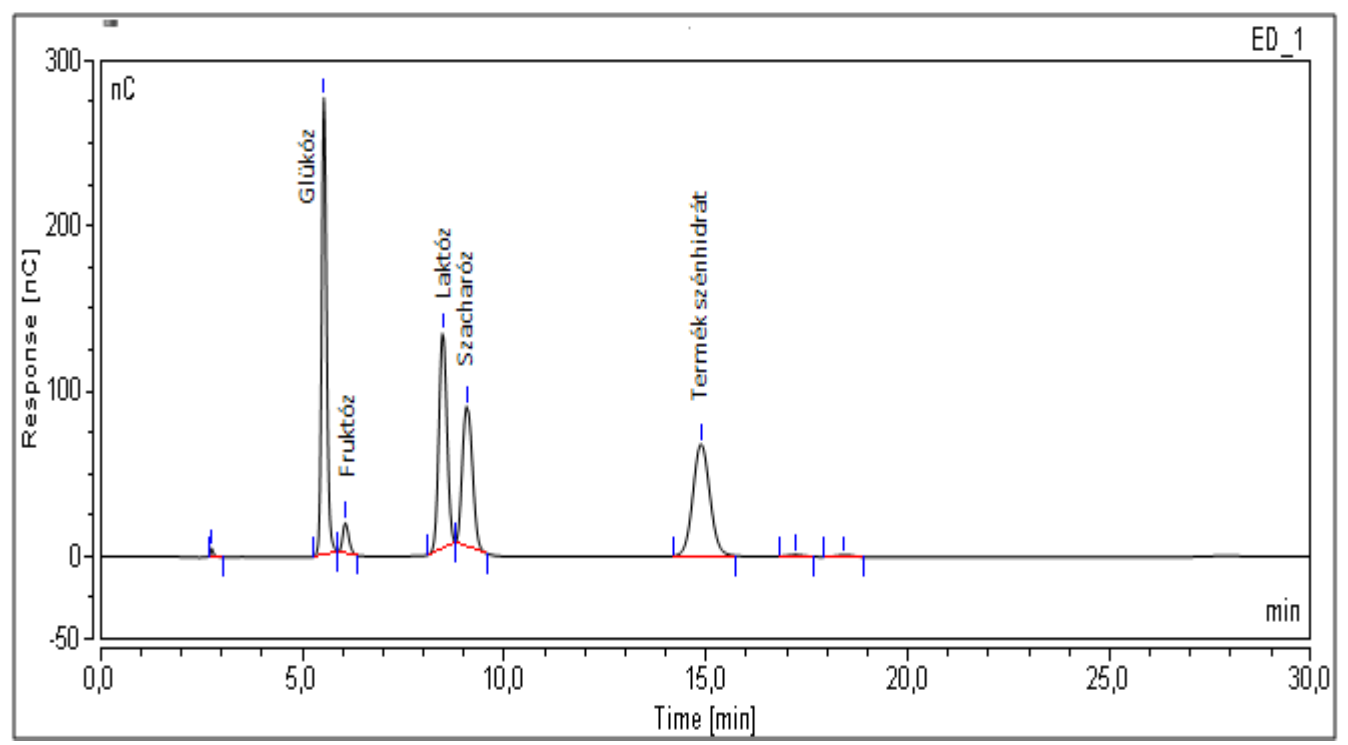

27. ábra: Szénhidrát összetétel a Bacillus megaterium eredetü levánszukrázzal, szacharóz:laktóz biszubsztrátumon végrehajtott biokonvezió 120. percében (paraméterek: $\mathrm{pH} 6,6,37^{\circ} \mathrm{C}, 61,5 \mathrm{~g} / 100 \mathrm{ml}$ szubsztrátum koncentráció, szacharóz:maltóz arány 1:2, detektálás: HPAEC-PAD technika)

A biokonverzió során mind a laktóz, mind a szacharóz mennyisége csökkent, a glükóz és a fruktóz mennyisége pedig növekedett. A glükóz nagyobb mennyiségben keletkezett, mint a fruktóz, tehát ez is bizonyítékként szolgál a transzfruktozilációs reakció végbemenetelére. Galaktóz képződés nem volt megfigyelhető, tehát az enzim nem képes a laktózt hidrolizálni, azonban mennyiségi csökkenése bizonyítja a reakcióban való részvételét. A kapott eredmények alapján megállapítható, hogy a Bacillus megaterium eredetủ levánszukráz szacharóz:laktóz biszubsztrátum rendszerben képes olyan transzfruktozilációs reakciót végrehajtani, amelyben a szacharóz donorként, a laktóz akceptorként vehet részt.

A szacharóz:laktóz arányok hatását vizsgálva megállapítható, hogy a $61,5 \mathrm{~g} / 100 \mathrm{ml}$ szusbsztrátum koncentráció és a szacharóz:laktóz 1:2 arányú közegében érhető el a legnagyobb hozam (28. ábra). E szubsztrátum kombináció esetében a 45. percben értem el a legnagyobb oligoszacharid mennyiséget $(21,36$ nC*perc). A 4 órás biokonverziót vizsgálva azt tapasztaltam, hogy a maximális termék koncentrációhoz szükséges idők az egyes szubsztrátum arányoknál eltérnek.

A levánszukráz enzimet már számos kutató tanulmányozta frukto-oligoszacharidok előállítása céljából (EUZENAT et al., 1997; ABDEL-FATTAH et al., 2005). A levánszukrázokról már bizonyították, hogy egyes szénhidrát akceptorok jelenlétében képesek oligoszacharidok szintézisére (TANAKA et al., 1981; OHTSUKA et al., 1992).

OHTSUKA és munkatársai (1992) kimutatták, hogy a Rahnella aquatilis eredetű levánszukráz által katalizált fruktozil-transzfer reakcióban szintén akceptorként szerepelhet a maltóz és a laktóz. PARK és munkatársai (2003) Microbacterium laevaniformans eredetű levánszukráz esetében ezt szintén kimutatták. A Bacillus megaterium eredetű rekombináns levánszukráz 
esetében azonban szacharóz:maltóz, mind szacharóz:laktóz biszubsztrátumokat még nem tanulmányozták, így eredményeimmel az enzim új felhasználási lehetőségeit tártam fel.

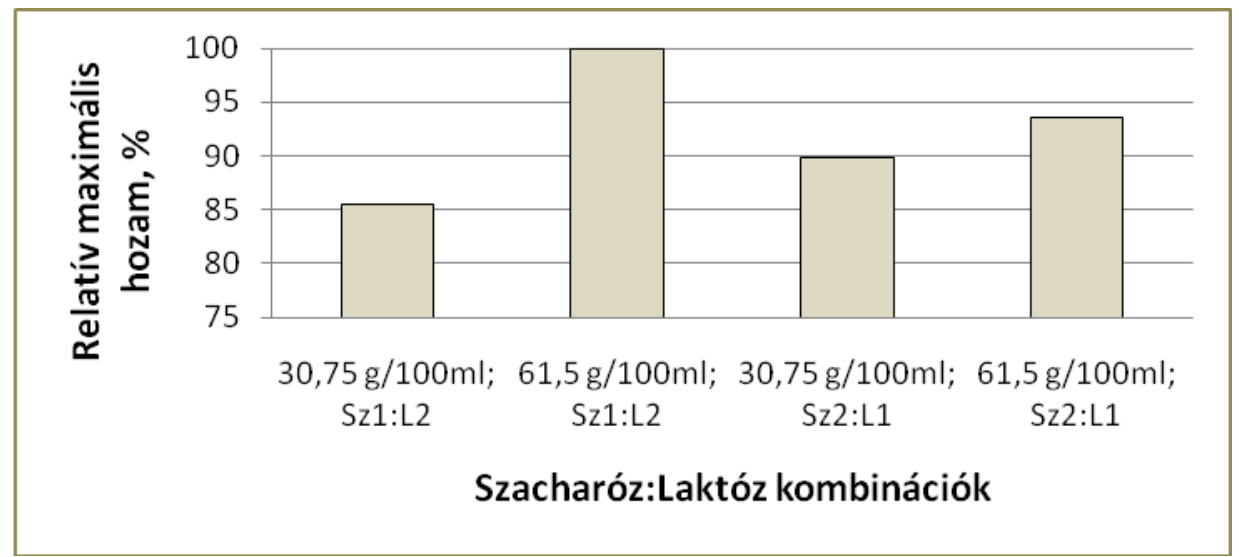

28. ábra: A szacharóz:laktóz arányának hatása a Bacillus megaterium eredetü levánszukráz transzglikozilációs aktivitására (paraméterek: $\mathrm{pH} 6,6,37^{\circ} \mathrm{C}, 4$ óra, detektálás: HPAEC-PAD technika)

Sz: szacharóz, L: laktóz

\subsubsection{Transzglikoziláció Bifidobacterium longum eredetü preparátummal}

\subsubsection{Különböző szubsztrátum kombinációk}

Doktori kutatásom során a Bifidobacterium longum Bb-46 eredetü preparátummal is végeztem biokonverziós kísérletet biszubsztrátum rendszerekben. A transzglikozilációs reakció vizsgálatához a laktózt és a laktulózt kombináltam maltózzal és szacharózzal, azok 1:1 arányát alkalmazva, 30 g/100ml szénhidráttartalmú közegben.

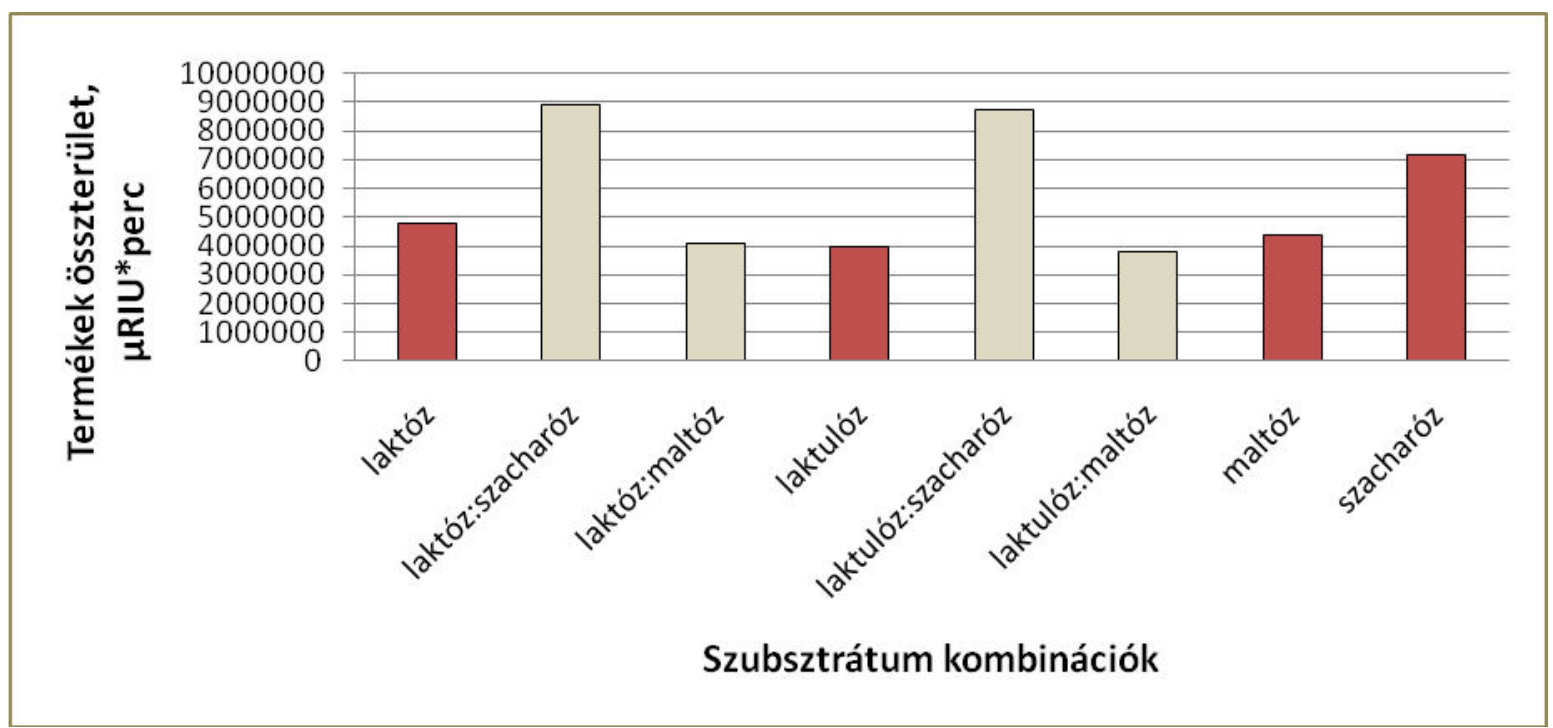

29. ábra: A 72. órában mért oligoszacharid tartalom a Bifidobacterium longum eredetü preparátumáltal katalizált transzglikozilációs reakciók esetén biszubsztrátum rendszerekben

(paraméterek: pH 6,6, $40^{\circ} \mathrm{C}, 30 \mathrm{~g} / 100 \mathrm{ml}$ szénhidrát tartalom, 1:1 arány, detektálás: HPLC-RID technika) 
A 29. ábra jól mutatja, hogy a laktózt és laktulóztszacharózzal való kombinálva kiemelkedő eredmény érhető el. A laktóz:szacharóz esetében $8907283 \mu$ RIU*perc, laktulóz:szacharóz $8748642 \mu \mathrm{RIU} *$ perc termék terület értéket értem el. Jó eredményt adtak a laktóz:maltóz (4079368 $\mu$ RIU*perc) és laktulóz:maltóz (3795981 $\mu$ RIU*perc) kombinációk is. Tekintve, hogy a preparátum minden alkalmazott monoszubsztrátumon katalizál transzglikozilációs reakciót, felvetődik a kérdés, a biszubsztrátumokon végbement oligoszacharid szintézis vajon több enzimnek köszönhetö-e.

Mivel több enzim van jelen a preparátumban és a Bifidobacterium eredetű enzimek transzglikozilációs reakcióiról is kevés ismeret áll rendelkezésre, így többféle reakció végbemenetelét tartom lehetségesnek a biszubsztrátumok alkalmazásával:

a) transzgalaktozilációval a laktóz/laktulóz galaktóz egysége átkerült egy másik laktóz/laktulóz molekulára

b) transzgalaktozilációval a laktóz/laktulóz galaktóz része átkerült maltózra/szacharózra

c) transzglükozilációval a maltóz/szacharóz glükóz egysége átkerült egy másik maltóz/szacharóz molekulára

d) transzglükozilációval a maltóz/szacharóz glükóz egysége átkerült a laktózra/laktulózra

\subsubsection{Optimális szubsztrátum koncentráció és szubsztrátum:szubsztrátum arány}

Biszubsztrátum rendszerek alkalmazásával elért eredményeim alapján érdemesnek tartottam további vizsgálatokat végezni. Egy kiemelkedő eredményt mutató (laktóz:szacharóz) és egy kevésbé kiemelkedő eredményt mutató (laktóz:maltóz) kombinációt választottam, hogy meghatározzam az optimális szubsztrátum koncentrációt és szubsztrátum arányt a maximális oligoszacharid hozamra nézve. A kísérleti eredmények értékelésére válaszfelületi módszert alkalmaztam a Statistica 9 programcsomag segítségével. A modellek illeszkedését regresszió analízissel elemeztem.

\section{Laktóz:szacharóz biszubsztrátum}

Alaktóz:szacharóz biszubsztrátum esetében, a regresszió analízis eredményeképpen a következő másodfokú polinom modell bizonyult megfelelőnek:

$$
\mathrm{z}=-2,60 \cdot 10^{6}+1,67 \cdot 10^{5} \cdot x+4,38 \cdot 10^{5} \cdot y-812,08 \cdot x^{2}-2711,71 \cdot x \cdot y-5403,12 \cdot y^{2}
$$

z: Oligoszacharid tartalom a 72. órában ( $\mu$ RIU*perc)

x: Laktóz arány (\%)

y: Szubsztrátum koncentráció $(\mathrm{g} / 100 \mathrm{ml})$

A modell determinációs állandója $\left(\mathrm{R}^{2}\right)$ 0,845, amit megfelelő illeszkedésnek tartottam. 
A regressziós analízis alapján mind a szubsztrátum koncentráció, mind a laktóz tartalom egyedüli, első- és másodfokú hatása valamint együttes hatásuk is szignifikánsan befolyásolja az oligoszacharid tartalom alakulását. Minden esetben a p-érték kisebb, mint a kritikus érték $(\alpha=0,05)$, valamint a t-próba értékei nagyobbak, mint a kritikus, tehát megállapítható, hogy a két faktor szignifikánsan befolyásolja az oligoszacharid szintézist. A regressziós analízis eredményeit a 17. táblázatban foglaltam össze.

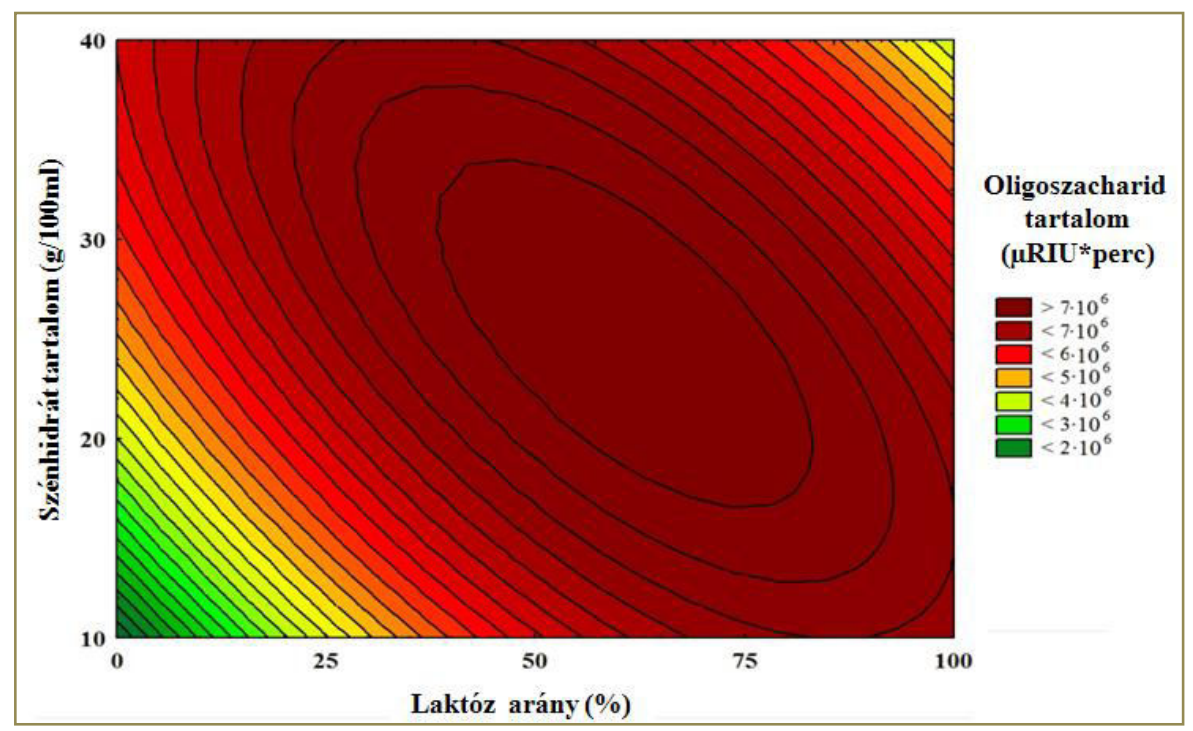

30. ábra: A szubsztrátum koncentráció és a laktóz:szacharóz arány hatása a Bifidobacterium longum eredetü preparátum oligoszacharid hozamára (paraméterek: $\mathrm{pH} 6,6,40^{\circ} \mathrm{C}, 72$. óra, detektálás: HPLC-RID technika)

17. táblázat: A regresszió analízis eredményei

\begin{tabular}{|cccc|}
\hline Változó & t-érték* & p-érték & t $_{\text {kritikus }}{ }^{* *}$ \\
\hline Laktóz arány $(\%)$ & 8,452 & $4,59 \cdot 10^{-11}$ & 1,676 \\
\hline Szubsztrátum konc. $(\mathrm{g} / 100 \mathrm{ml})$ & 4,898 & $1,14 \cdot 10^{-5}$ & 1,676 \\
\hline Laktóz arány $^{2}(\%)$ & 5,525 & $1,32 \cdot 10^{-6}$ & 1,676 \\
\hline Interakció $^{-5}$ & 5,545 & $1,23 \cdot 10^{-6}$ & 1,676 \\
Szubsztrátum konc. $^{2}(\mathrm{~g} / 100 \mathrm{ml})$ & 3,243 & 0,0022 & 1,676 \\
\hline
\end{tabular}

(paraméterek: Bifidobacterium longum eredetű preparátum, $\mathrm{pH} 6,6,40{ }^{\circ} \mathrm{C}$, 72 . óra, detektálás: HPLC-RID technika, laktóz:szacharóz arány 0:100 - 100:0 szubsztrátum koncentráció 10 - 40 g/100ml, értékelés: STATISTICA 9)

* t-értékek 48-as szabadsági fok mellett számított értékei

** Student-féle t-eloszlás táblázatból (szf=48)

A 30. ábrán látható kétdimenziós hatásfelület ábra jól mutatja a két független változó hatását az oligoszacharid tartalom változására.

A statisztikai próbák eredményei arról tanúskodnak, hogy a laktóz (szacharóz) aránynak van a legnagyobb hatása az oligoszacharid szintézisre, míg a szubsztrátum koncentráció négyzetének a legkisebb. A modell további együtthatói szintén jelentős hatással bírnak, így nem elhanyagolhatóak. 
A kapott modell alapján meghatározhatók a maximális oligoszacharid tartalom eléréséhez tartozó szubsztrátum koncentráció és laktóz arány, ami $25 \mathrm{~g} / 100 \mathrm{ml}$, valamint $61 \%$ laktóz (39\% szacharóz).

A termék spektrum analízisére TLC módszert alkalmaztam. A 31. ábrán látható, hogy szacharóz kontrol esetében 30 g/100ml koncentráció esetében 3 féle, 10 g/100ml szubsztrátum koncentráció esetében 4 féle oligoszacharid, valamint polimerek szintetizálódtak. Csak laktózt alkalmazva szubsztrátumként, 2 féle oligoszacharid termék állítható elő. A két szubsztrátumot együtt alkalmazva egy eltérő retencióval rendelkező oligoszacharidot detektáltam, amely $30 \mathrm{~g} / 100 \mathrm{ml}$ szubsztrátum koncentrációnál már a transzfer reakció fő terméke volt. A biokonverzió során csak fruktóz és glükóz keletkezett, így feltételezem, hogy transzgalaktozilációs reakcióval keletkezett az új termék szénhidrát. Tehát a Bifidobacterium longum eredetü enzimpreparátum ( $\beta$-galaktozidáz enzime) képes a laktóz molekulában lévő galaktózt a szacharózra átvinni. LI és munkatársai (2009) Bacillus circulans eredetü $\beta$-galaktozidáz esetében szintén vizsgálták ezt a biszubsztrátum rendszert különböző arányok esetében. Az általuk alkalmazott enzimmel lakto-szacharózt és annak különböző analógjait szintetizálták, az optimális laktóz:szacharóz arány 50:50 volt.

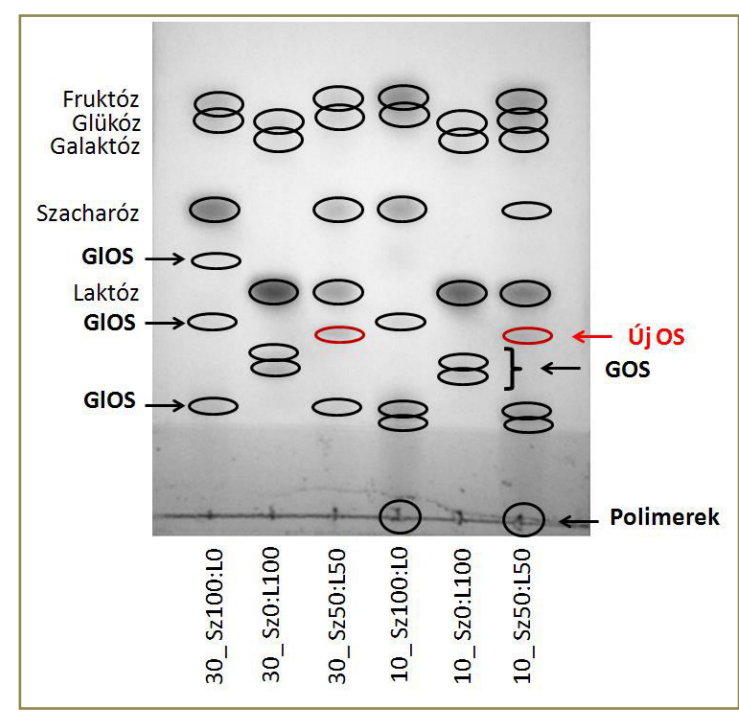

31. ábra: Szénhidrát összetétel Bifidobacterium longum eredetű preparátum által, a laktóz:szacharóz biszubsztrátum katalizált transzglikozilációs reakció 72. órájában (paraméterek: $\mathrm{pH} 6,6,40^{\circ} \mathrm{C}$, szubsztrátum koncentráció: $10 \mathrm{~g} / 100 \mathrm{ml}, 30 \mathrm{~g} / 100 \mathrm{ml}$, szacharóz:laktóz arányok: 100:0, 50:50, 0:100)

30_Sz100:L0: 30 g/100ml szacharóz,30_Sz0:L100: $30 \mathrm{~g} / 100 \mathrm{ml}$ szacharóz, 30_Sz50:L50: $15 \mathrm{~g} / 100 \mathrm{ml}$ szacharóz, 15 g/100ml laktóz,10_Sz100:L0: 10 g/100ml szacharóz,10_Sz0:L100: 10 g/100ml laktóz,10_Sz50:L50: 5 g/100ml szacharóz, 5 g/100ml laktóz 


\section{Laktóz:maltóz biszubsztrátum}

Munkámban megvizsgáltam a szubsztrátumok arányának és a szubsztrátum koncentráció hatását laktóz:maltóz biszubsztrátumon is. Az előző fejezethez hasonlóan ebben az esetben is válaszfelületi módszert alkalmaztam az adatok értékelésére. Az illesztett modell a következő:

\section{$z=-4,8581 E 5+27797,0904 * x+1,8099 E 5 * y-242,9663 * x * x-283,1376 * x * y-728,4469 * y * y$}

z: Oligoszacharid tartalom a 72. órában ( $\mu$ RIU*perc)

x: Laktóz arány (\%)

y: Szubsztrátum koncentráció $(\mathrm{g} / 100 \mathrm{ml})$

18. táblázat: A regresszió analízis eredményei

\begin{tabular}{|c|c|c|c|}
\hline Változó & t-érték & p-érték & t kritikus \\
\hline Laktóz arány (\%) & 3,057 & 0,00365 & 1,676 \\
\hline Szubsztrátum konc. (g/100ml) & 4,402 & 0,00006 & 1,676 \\
\hline Laktóz arány ${ }^{2}(\%)$ & 3,592 & 0,00077 & 1,676 \\
\hline Interakció & 1,258 & 0,21446 & 1,676 \\
\hline Szubsztrátum konc. ${ }^{2}(\mathrm{~g} / 100 \mathrm{ml})$ & 0,950 & 0,34694 & 1,676 \\
\hline
\end{tabular}

(paraméterek: Bifidobacterium longum eredetű preparátum, $\mathrm{pH} 6,6,40{ }^{\circ} \mathrm{C}$, 72 . óra, detektálás: HPLC-RID technika, laktóz:maltóz arány 0:100 - 100:0 szubsztrátum koncentráció 10 - 40 g/100ml, értékelés: STATISTICA 9)

A regressziós eredmények alapján (18. táblázat) a modell két tagja, az interakció és szubsztrátum koncentráció négyzetének hatása elhagyható, ugyanis e két változó esetében a $0,05 \leq p$ és t-érték $\leq$ t-kritikus. Így egy egyszerüsített modellt javaslok az oligoszacharidok hozamának leírására, a szubsztrátum arány és koncentráció függvényében:

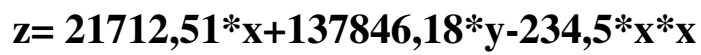

z: Oligoszacharid tartalom a 72. órában ( $\mu$ RIU*perc)

x: Laktóz arány $(\%)$

y: Szubsztrátum koncentráció $(\mathrm{g} / 100 \mathrm{ml})$

A Statistica program segítségével háromdimenziós hatásfelületi ábrát készítettem (32. ábra), mely szemlélteti a két független változó hatását az oligoszacharid tartalom változására. A modell determinációs állandója $\left(\mathrm{R}^{2}\right)$ 0,948, mely megfelelő illeszkedést jelent. 


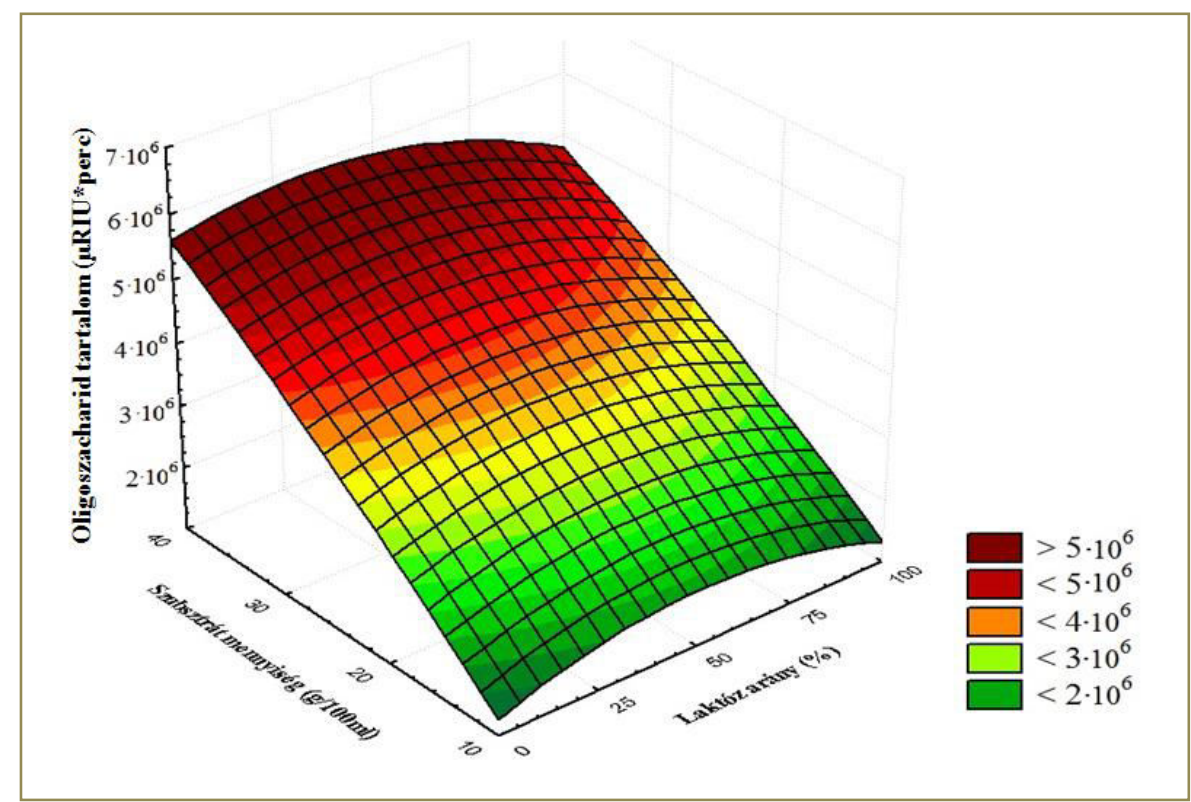

\section{2. ábra: A szubsztrátum koncentráció és a laktóz:maltóz arány hatása a Bifidobacterium longum eredetü preparátum oligoszacharid hozamára (paraméterek: $\mathrm{pH} 6,6,40^{\circ} \mathrm{C}, 72$. óra, detektálás: HPLC-RID technika)}

A korrigált modell regressziós analízisével kapott eredmények a 19. táblázatban láthatók, eszerint a laktóz aránynak első- és másodfokú, a szubsztrátum koncentrációnak elsőfokú hatása van az oligoszacharid hozamra. A kapott modell alapján az optimális szubsztrátum koncentráció 40 g/100ml és az optimális laktóz arány 33\% (maltóz 67\%) (a mérési tartományon belül).

19. táblázat: A regresszió analízis erdeményei az egyszerüsített modell esetében

\begin{tabular}{|lrrr|}
\hline Változó & t-érték & p-érték & t kritikus \\
\hline Laktóz arány (\%) & 3,645 & 0,000626 & 1,676 \\
\hline Szubsztrátum konc. (g/100ml) & 32,639 & 0,000000 & 1,676 \\
\hline Laktóz arány2 (\%) & 3,747 & 0,000457 & 1,676 \\
\hline
\end{tabular}

(paraméterek: Bifidobacterium longum eredetủ preparátum, $\mathrm{pH} 6,6,40^{\circ} \mathrm{C}, 72$. óra, detektálás: HPLC-RID technika, laktóz:maltóz arány 0:100 - 100:0 szubsztrátum koncentráció 10 - 40 g/100ml, értékelés: STATISTICA 9)

A TLC vizsgálat eredményei alapján (33. ábra) igazolt, hogy laktóz:maltóz kombinációval is keletkezik egy új, monoszubsztrátumok esetében nem detektált, oligoszacharid. A 30 g/100ml szubsztrátum koncentráció esetén csak a glükóz jelent meg, mint hidrolízis termék, ezért a laktóz:szacharóz kombinációhoz hasonlóan itt is valószínüsíthető a galaktóz transzfer végbemenetele. 


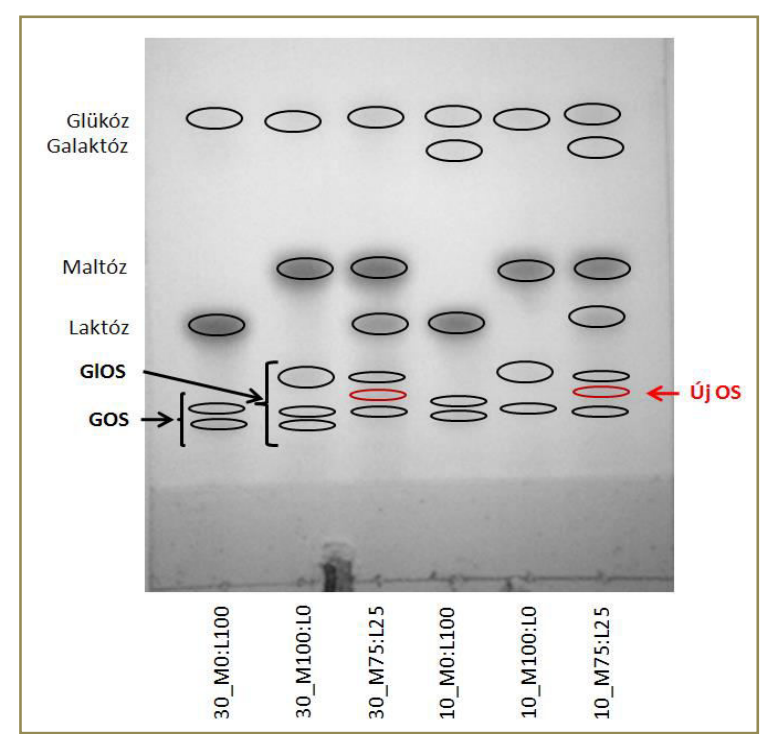

33. ábra: Szénhidrát összetétel Bifidobacterium longum eredetü preparátum által, a laktóz:Szacharóz biszubsztrátum katalizált transzglikozilációs reakció 72. órájában (paraméterek: $\mathrm{pH} 6,6,40^{\circ} \mathrm{C}$, szubsztrátum koncentráció: $10 \mathrm{~g} / 100 \mathrm{ml}, 30 \mathrm{~g} / 100 \mathrm{ml}$, szacharóz:laktóz arányok: 100:0, 50:50, 0:100)

(30_M100:L0: 30 g/100ml maltóz,30_M0:L100: 30 g/100ml laktóz, 30_M75:L25: 22,5 g/100ml maltóz, 7,5 g/100ml laktóz,10_M100:L0: 10 g/100ml maltóz,10_M0:L100: 10 g/100ml laktóz,10_M75:L25: 7,5 g/100ml maltóz, $2,5 \mathrm{~g} / 100 \mathrm{ml}$ laktóz)

SCHWAB és munkatársai (2011) állítottak elő Bifidobacterium longum eredetű $\beta$-galaktozidáz enzimet, majd megvizsgálták biokonverziós képességét biszubszrátum rendszerben. Az általuk alkalmazott fehérjepreparátum laktóz:mannóz, laktóz:fukóz és laktóz: $N$-acetil-glükózamin szubsztrátumokon szintetizált új oligoszacharidokat. A laktóz:szacharóz és laktóz:maltóz biszubsztrátumokat nem vizsgáltak még Bifidobacterium eredetü $\beta$-galaktozidázzal/preparátummal, azonban az általam illetve ScHWAB és munkatársai (2011) által elért eredményekből arra lehet következtetni, hogy a Bifidobacterium longum faj által termelt $\beta$-galaktozidázok kismértékü specifitást mutatnak az akceptor molekulára, így érdemes lehet további tanulmányozásuk új oligoszacharidok szintézise szempontjából.

\section{3 Új tudományos eredmények}

1. A Pectinex ultra SP-L enzimkészítménnyel sikeresen valósítottam meg transzglikozilezési és reverz hidrolízis reakciókat. A készítmény cellobiózon, maltózon, maltulózon, palatinózon, trehalózon és turanózon transzglükozil reakciót, melibiózon transzgalaktozil reakciót katalizált. Reverz hidrolízis reakciót mutattam ki glükóz és mannóz szubsztrátumon.

2. Meghatároztam a Pectinex ultra SP-L készítménnyel történő mannóz alapú oligoszacharid szintézis optimális paramétereit: 60 g/100ml szubsztrátum koncentráció, 
$\mathrm{pH} 5,0,70{ }^{\circ} \mathrm{C}, 3,1 \mathrm{mg}$ fehérje/g szénhidrát. Megállapítottam, hogy ezen a szubsztrátumon $\mathrm{DP}_{2}-\mathrm{DP}_{6}$ manno-oligomerek szintetizálhatók.

3. Bizonyítottam, hogy a Pectinex ultra SP-L enzimkészítmény transzglikozilációs reakciót katalizál maltóz:szacharóz biszubsztrátumon, mellyel egy a malto- és fruktooligoszacharidoktól eltérő retenciójú oligomer mutatható ki (TLC módszerrel).

4. A Bacillus megaterium eredetű rekombináns levánszukráz enzim új akceptorait fedeztem fel és bizonyítottam, hogy az enzim képes olyan transzfruktozilációs reakciót katalizálni, melyben a fruktóz a szacharózból a maltózra és a laktózra is átvihető.

5. Előállítottam egy Bifidobacterium longum Bb-46 eredetü $\beta$ enzimpreparátumot, és bizonyítottam, hogy képes transzglikozilációs reakciót katalizálni laktóz, laktulóz, maltóz és szacharóz szubsztrátumokon.

6. Bifidobacterium longum Bb-46 eredetű enzimpreparátum alkalmazásával biszubsztrátumos rendszerekben, laktóz:maltóz és laktóz:szacharóz esetében, optimáltam az oligoszacharidok $\left(\mathrm{DP}_{3}-\mathrm{DP}_{4}\right)$ szintézisét az oligoszacharid tartalomra nézve. Optimális szubsztrátum arányuk és koncentrációjuk: Laktóz:maltóz esetében 33:67 és 40 g/100ml, laktóz:szacharóz esetében 61:39 és 25 g/100ml. 
DOI: 10.14267/phd.2015034 


\section{KÖVETKEZTETÉSEK ÉS JAVASLATOK}

Doktori kutatómunkám célja különböző oligoszacharidok enzimes szintézisének a tanulmányozása volt mono- illetve biszubsztrátumok alkalmazásával. Ennek megvalósítására a kereskedelmi forgalomban kapható, Aspergillus aculeatus eredetü Pectinex ultra SP-L enzimkészítményt, a Bacillus megaterium eredetủ levánszukráz enzimet és egy Bifidobacterium longum eredetü fehérje preparátumot alkalmaztam.

A Pectinex ultra SP-L készítmény $\beta$-galaktozidáz és fruktozil-transzferáz kísérő enzimeit már számos kutató alkalmazta galakto- illetve frukto-oligoszacharidok előállítására. Kutatómunkám során azonban a készítmény további enzimeit bizonyítottam. Megállapítottam, hogy a készítmény alkalmazásával oligoszacharidok szintetizálhatók transzglükoziláció révén cellobióz, maltóz, maltulóz, palatinóz, turanóz és trehalóz diszacharidokon, transzgalaktozilációval melibiózon. Emellett reverz hidrolízis reakciót is katalizál a készítmény mannóz és glükóz monoszacharidokon. A készítmény újonnan igazolt aktivitásainak feltárása tovább bővítheti különböző oligoszacharidok előállítási lehetőségeit.

Megállapítottam, hogy a mannóz alapú szintézis során öt különböző polimerizáltságú szénhidrát termék szintetizálható, $\mathrm{DP}_{2}-\mathrm{DP}_{6}$. Korábban megjelent tanulmányokban maximálisan tetraszacharid oligomert szintetizáltak. Ezért az Aspergillus aculeatus eredetü $\alpha$-mannozidáz alkalmazása hasznos lehet nagy polimerizáltsági fokú manno-oligoszacharidok előállítására.

A készítményt biszubsztrátum rendszerekben vizsgálva megállapítottam, hogy maltóz:szacharóz kombinációjával a monoszubsztrátumok esetén detektált termékektől eltérő szerkezetü oligoszacharid állítható elő. A szénhidrát összetétel alakulását elemezve feltételezehető a transzfruktozilációs reakció végbemenetele, amelyben a szacharóz donorként, a maltóz akceptorként vesz részt. A Bacillus megaterium eredetủ levánszukráz eddig nem ismert új akceptorait (maltóz és laktóz) fedeztem fel. Bifidobacterium longum eredetű enzimpreparátum alkalmazásával oligoszacharidokat állítottam elő laktóz:maltóz és laktóz:szacharóz biszubsztrátumokon.

E biszubsztrátum rendszerek tanulmányozásával kapott eredményeim utat nyithatnak új oligoszacharidok előállításának technológiai kidolgozására. Az elállított termékek hasznosíthatóságának megállapítására, szükség lehet azok pontos szerkezetének meghatározása. Szükséges kutatási iránynak tartom annak vizsgálatát és bizonyítását, hogy a különböző probiotikus baktériumok képesek-e hasznosítani a szintetizált szénhidrátokat, illetve e szacharidok rendelkeznek-e prebiotikus vagy más kedvező 
fiziológiai tulajdonsággal. A munka további folytatásaként érdemes lenne a preparátumok szintézist katalizáló enzimeinek a tisztítása és jellemzése is. 


\section{6 ÖSSZEFOGLALÁS}

Az oligoszacharidok a biológiai rendszerek egy jelentős vegyületcsoportja, amely fontos szerepet tölt be a biológiai/biokémiai folyamatokban, a szerkezetek felépítésében, valamint az energiaraktározásban. Tudományos és klinikai bizonyítékok állnak rendelkezésre, hogy egyes oligoszacharidok jótékony fiziológiai hatással is rendelkeznek. Jelenleg számos oligoszacharid enzimes előállítása iparilag megvalósított. Emellett sorra jelennek meg új tanulmányok különböző összetételü és szerkezetű szénhidrátok/oligoszacharidok és szénhidrátszármazékainak előállításáról.

Doktori kutatómunkám célja különböző eredetü enzimpreparátumok transzglikozilációs és reverz hidrolízis aktivitásának tanulmányozása oligoszacharidok szintézis lehetőségeinek feltárására mono- és biszubsztrátum rendszerek használatával. Ennek megvalósításához kereskedelmi forgalomban kapható Aspergillus aculeatus eredetű enzimkészítményt (Pectinex ultra SP-L), Bacillus megaterium eredetű rekombináns levánszukráz enzimet, valamint egy Bifidobacterium longum eredetü preparátumot alkalmaztam.

Eredményeim bizonyították, hogy a Pectinex ultra a specifikációjában szereplő pektolitikus aktivitások mellett számos más mellékaktivitással rendelkező enzimet is tartalmaz, amelyek felhasználásával különböző oligoszacharidok szintetizálhatók. Igazoltam, hogy alkalmazásával transzglükozilációs reakció vihető véghez cellobióz, maltóz, maltulóz, palatinóz, trehalóz és turanóz szubsztrátumokon. Emellett megállapítottam, hogy a készítmény a $\beta$-galaktozidos kötések mellett, $\alpha$-galaktozidos kötést tartalmazó szubsztrátumon (melibiózon) is képes hidrolízis és transzglikozilációs reakciót katalizálni. Monoszacharidokon történő biokonverziós vizsgálatok során megállapítottam, hogy a készítmény reverz hidrolízissel glükózból és mannózból képes nagyobb polimerizáltságú szénhidrátok előállítására. Az alkalmazott körülmények között arabinózon, fruktózon, ramnózon, szorbózon és xilózon nem mutattam ki di/oligoszacharid szintézist.

Tekintve a manno-oligoszacharidok jelentős biológiai szerepét, a mannóz alapú szintézist tartottam érdemesnek részletesebben tanulmányozni. Vizsgáltam a reakció körülmények változtatásának hatását és a következő környezeti paraméterek között értem el a legnagyobb termék hozamot: 60 g/100ml mannóz koncentráció; pH 5,0; 70 º $\mathrm{C} ; 3,1 \mathrm{mg}$ fehérje/g szubsztrátum. A Maillard reakció gátlásának hatását is vizsgáltam. Munkámban 3 inhibitort teszteltem: o-fenilén-diamin-dihidroklorid, szemikarbazid-hidroklorid, aminoguanidinhidroklorid. Megállapítottam, hogy az aminoguanidin-hidroklorid alkalmazásával a kontrolhoz (inhibitor nélküli) képest nagyobb termékhozam érhető el. A többi inhibitor jelenléte nem fokozta a termék szintézist. 
A mannóz alapú szintézis termékeinek tisztítására BioGel-P2 töltetű oszlopot választottam.Az elválasztás során kinyert termékek MALDI-TOF-MS módszerrel (Debreceni Egyetem Szervetlen és Analitikai Kémiai Tanszékén) történő analízise során megállapítottam, hogy a mannóz szubsztrátumon reverz hidrolízissel 5 különböző polimerizáltságú termék $\left(\mathrm{DP}_{2}-\mathrm{DP}_{6}\right)$ állítható elő,. A BioGel-P2 oszlopon történő elválasztással 1 tiszta triszacharid terméket sikerült kinyernem. A termékszerkezet tanulmányozása jelenleg még folyik.

A Pectinex ultra készítményt biszubsztrátum rendszerekben vizsgálva megállapítottam, hogy maltóz:szacharóz párosításával olyan oligoszacharid termék állítható elő, mely a monoszubsztrátumok (szacharóz, maltóz) esetén nem detektálható TLC módszerrel. A két szubsztrátum optimális aránya 1:9 (maltóz:szacharóz), az optimális szubsztrátum koncentráció $60 \mathrm{~g} / 100 \mathrm{ml}$. E paramétereket alkalmazva a kontrolhoz képest kb. kétszeres oligoszacharid hozamot értem el. A szénhidrát összetétel alakulását elemezve feltételezehető a transzfruktozilációs reakció végbemenetele, melyben a szacharóz donorként, a maltóz akceptorként vesz részt.

A Bacillus megaterium eredetü levánszukráz enzimet is alkalmaztam oligoszacharid szintézisre, amelyet szacharóz:maltóz, illetve szacharóz:laktóz biszubsztrátum rendszerekben vizsgáltam. Megállapítottam, hogy e biszubsztrátumok esetén a transzfrukozilációs reakcióban a maltóz és a laktóz akceptorként vehet részt. A szacharóz:maltóz biszubsztrátummal 2:1 (szacharóz:maltóz) szubsztrátum arány és $61,5 \mathrm{~g} / 100 \mathrm{ml}$ szubsztrátum koncentráció esetén értem el a legnagyobb oligoszacharid hozamot, szacharóz:laktóz biszubsztrátummal ezek az értékek 1:2 arány és 61,5 $\mathrm{g} / 100 \mathrm{ml}$.

Tanulmányoztam a biszubsztrátum rendszereket Bifidobacterium longum eredetű enzimpreparátum alkalmazásával. A laktózt és laktulózt kombináltam maltóz és szacharóz szénhidrátokkal. Megállapítottam, hogy a monoszubsztrátumokhoz képest a laktulóz:szacharóz és laktóz:szacharóz biszubsztrátum rendszerekkel fokozható az oligoszacharid képzés.

A laktóz:szacharóz és laktóz:maltóz biszubsztrátum rendszerekben megállapítottam az optimális szubsztrátum arányt és szubsztrátum koncentrációt: laktóz:szacharóz esetében 61:39 és 25 g/100ml, laktóz:maltóz esetében 33:67 és $40 \mathrm{~g} / 100 \mathrm{ml}$ volt. Mindkét biszubsztrátum alkalmazásával a monoszubsztrátumok esetében detektált termékektől eltérő retenciójú terméket detektáltam TLC módszerrel. A szénhidrát összetétel alakulásából következtethető, hogy az új termékek transzgalaktozilációs reakcióval jöttek létre, amelyben a laktóz donorként a szacharóz vagy a maltóz akceptorként szerepelt.

Doktori kutatásom eredményei elsősorban tudományos alapismeretek és hozzájárulhatnak az oligoszacharid szintézisek katalitikus mechanizmusainak jobb megértéséhez, a biológiai 
funkciók feltárásához, valamint elősegíthetik kívánt funkciójú/szerkezetű termék(ek) előállítását szolgáló enzimes technológiák fejlesztését.

A Pectinex ultra enzimkészítmény sokrétü vizsgálata nyomán, távlati kutatási célként megfogalmazódhat a penészgomba eredetü készítmény kisérő enzimeinek termelésnövelésére irányuló biomérnöki, mikrobiológiai és molekuláris genetikai fejlesztő kutatás. 
DOI: 10.14267/phd.2015034 


\section{SUMMARY}

It is well known that oligosaccharides play an important role in biological systems. They are involved in many biological/biochemical processes, in conformation of different biomolecules, and serve as energy storage molecules. Additionally, many clinical and scientific evidences are available which prove that some oligosaccharides have beneficial physiological properties. Nowadays, enzymatic production of several oligosaccharides is implemented on industrial scale. Moreover, studies dealing with the synthesis of different types of carbohydrates, oligosaccharides or carbohydrate derivatives with special structures were carried out intensively worldwide.

My doctoral research focused on the study of the reverse hydrolysis and transglycosylation activities of different enzyme preparations using both mono- and bisubstrate systems for the production of oligosaccharides. Three enzyme preparations were applied: Pectinex ultra SP-L (commercially available enzyme preparation from Aspergillus aculeatus), levansucrase from Bacillus. megaterium, and crude enzymes from Bifidobacterium longum.

Based on my results, Pectinex ultra preparation has several activities to synthesize oligosaccharides. The preparation catalyzed transglycosyl reaction on cellobiose, maltose, maltulose, palatinose, trehalose and turanose. Interestingly, it was able to hydrolyse both alphagalactoside and beta-galactoside bonds, as well as to transfer galactose from one to another substrate molecule. Reverse hydrolysis reaction was observed on glucose and mannose substrates resulting carbohydrate products with higher polymerization degree. On the other hand neither disaccharides nor oligosaccharides were detected on arabinose, fructose, rhamnose, sorbose and xylose.

Taking into consideration the importance of manno-oligosaccharides, synthesis of mannose based saccharides was selected for detailed study. The effects of different conditions on the production of oligosaccharides were investigated. The highest oligosaccharide yield was obtained at $60 \mathrm{~g} / 100 \mathrm{ml}$ mannose concentration, $\mathrm{pH} 5.0,70{ }^{\circ} \mathrm{C}, 3.1 \mathrm{mg}$ protein $/ \mathrm{g}$ product. Three Maillard inhibitors (o-phenilene-diamine-dihydrochloride, semicarbazide-hydrochloride and aminoguanidine-hydrochloride) were tested to enhance the synthesis of oligosaccharide. Addition of aminoguanidine-hydrochloride increases the yield of product compared to control run (without inhibitor). The other two inhibitors had no effects on the production of oligosaccharides.

The mannose-based products were separated using gelfiltration with BioGel-P2 column, and the collected fractions were analysed by MALDI-TOF-MS technique (at the Department of 
Inorganic and Analytical Chemistry, University of Debrecen, Hungary). The results showed that at least five types of oligosaccharides with polymerisation degree of $\mathrm{DP}_{2}$ to $\mathrm{DP}_{6}$ were synthesized on mannose substrate via reverse hydrolysis reaction. Structural analyses of these products are in progress.

Transglycosylation activities of Pectinex ultra were also investigated in different bisubstrate systems. In case maltose and sucrose were present in the system, an oligosaccharide was detected that did not appaere in monosubstrate (sucrose or maltose) systems used as controls (according to TLC method). The optimal ratio of maltose:sucrose and the optimal substrate concentration were determined to be $1: 9$ and $60 \mathrm{~g} / 100 \mathrm{ml}$, respectively. Double oligosaccharide yield was achieved if optimal condition was applied. Based on the changes of carbohydrate composition and concentration, the synthesis of oligosaccharide on the maltose:sucrose bisubstrate system may be due to a transfructosyl reaction in which the sucrose acts as a donor and the maltose as an acceptor.

Production of oligosaccharides by levansucrase from Bacillus megaterium was also investigated. Two kinds of bisubstrate (sucrose:maltose and sucrose:lactose) were applied. This enzyme can catalyze transfructosyl reaction in both systems, and both maltose and lactose can be acceptors of levansucrase. While in the case of sucrose:maltose the highest yield was achieved at 2:1 substrate ratio and $61.5 \mathrm{~g} / 100 \mathrm{ml}$ substrate concentration, respectively, whereas in the case of sucrose:lactose at 1:2 ratio and $61.5 \mathrm{~g} / 100 \mathrm{ml}$ substrate concentration.

Transglycosylation by crude enzyme preparation of Bifidobacterium longum on bisubstrate system was also investigated. Lactose and lactulose were combined with maltose and sucrose. In the cases of lactulose:sucrose and lactose:sucrose bisubstrate systems, the yields of oligosaccharides were significantly higher than the ones observed in the cases of monosubstrates. The optimal substrate ratio and substrate concentration of the combination of lactose:sucrose were $61: 39$ and $25 \mathrm{~g} / 100 \mathrm{ml}$, respectively. In the case of lactose:maltose, these values were changed to be $33: 67$ and $40 \mathrm{~g} / 100 \mathrm{ml}$. In both cases of bisubstrate systems, a product with different retention (on TLC) was detected, which are not produced in monosubstrate systems.

According to the change of carbohydrate composition, the synthesis of these products may be caused by transgalactosylation reaction. In these reactions lactose can act as donor, maltose and sucrose as acceptor molecules.

Results that were generated in my doctoral research are fundamentals, but I believe they contribute to the better understanding of catalytic mechanisms, and biological functions (control and operation). Such basic knowledge will also contribute to the elaboration of enzymatic technologies that can provide products with the required function or structure. 
The perspective in case of Pectinex ultra enzyme preparation is the study and improvement of the production of newly detected enzymes by strain development or by molecular biological methods. 
DOI: 10.14267/phd.2015034 


\section{IRODALOMJEGYZÉK}

Abdel-Fattah A. F., Mahmoud D. A. R., Esawy M. A. T. (2005): Production of levansucrase from Bacillus subtilis NRC 33a and enzymic synthesis of levan and fructo-oligosaccharides. Current Microbiology, 51 (6): $402-$ 407. p. http://dx.doi.org/10.1007/s00284-005-0111-1

AIDER M., de Halleux D. (2007): Isomerization of lactose and lactulose production: review. Trends in Food Science \& Technology, 18: 356-364. p. http://dx.doi.org/10.1016/j.tifs.2007.03.005

AJISAKA K., Fujimoto H., Isomura M. (1994): Regioselective transglycosylation in the synthesis of oligosaccharides: comparison of $\beta$-galactosidases and sialidases of various origins. Carbohydrate Research, 259 (1): 103-115. p. http://dx.doi.org/10.1016/0008-6215(94)84201-9

AJISAKA K., Matsuo I., Isomura M., Fujimoto H., Shirakabe M., Okawa M. (1995): Enzymatic synthesis of mannobioses and mannotrioses by reverse hydrolysis using $\alpha$-mannosidase from Aspergillus niger. Carbohydrate Research, 270 (2): 123-130. p. http://dx.doi.org/10.1016/0008-6215(95)00015-L

AJISAKA K., Nishida H., Fujimoto H. (1987): The synthesis of oligosaccharides by the reversed hydrolysis reaction of $\beta$-glucosidase at high substrate concentration and at high temperature. Biotechnology Letters, 9 (4): 243-248. p. http://dx.doi.org/10.1007/BF01027157

AKAIKe E., Tsutsumida M., Osumi K., fujita M., Yamanoi T., Yamamoto K., Fujita K. (2004): High efficiency of transferring a native sugar chain from a glycopeptide by a microbial endoglycosidase in organic solvents. Carbohydrate Research, 339 (3): 719-722. p. http://dx.doi.org/10.1016/j.carres.2003.12.007

Al-Assaf S., Phillips G. O., Williams P. A., du Plessis T. A. (2007): Application of ionizing radiations to produce new polysaccharides and proteins with enhanced functionality. Nuclear Instruments and Methods in Physics Research Section B: Beam Interactions with Materials and Atoms, 265: 37-43. p. http://dx.doi.org/10.1016/j.nimb.2007.08.015

ALbaYRAK N., Yang S-T. (2002): Production of galacto-oligosaccharides from lactose by Aspergillus oryzae $\beta$ galactosidase immobilized on cotton cloth. Biotechnology and Bioengineering, 77 (1): 8-19. p. http://dx.doi.org/10.1002/bit.1195

ALI M. B., Mhiri S., Meghani M., Bejar S. (2001): Purification and sequence analysis of the atypical maltohexaoseforming $\alpha$-amylase of the B. stearothermophilus US100. Enzyme and Microbial Technology, 28 (6): 537-542. p. http://dx.doi.org/10.1016/S0141-0229(01)00294-0

Áĺlvaro-Benito M., de Abreu M., Fernández-Arrojo L., Plou F. J., Jiménez-Barbero J., Ballesteros A., Polaina J., Fernández-Lobato M. (2007): Characterization of a $\beta$-fructofuranosidase from Schwanniomyces occidentalis with transfructosylating activity yielding the prebiotic 6-kestose. Journal of Biotechnology, 132 (1): 75-81. p. http://dx.doi.org/10.1016/j.jbiotec.2007.07.939

AndreotTi G., Giordano A., Tramice A., Mollo E., Trincone A. (2006): Hydrolyses and transglycosylations performed by purified $\alpha$-D-glucosidase of the marine mollusc Aplysia fasciata Journal of Biotechnology, 122: 274-284. p. http://dx.doi.org/10.1016/j.jbiotec.2005.10.002

Argüello-Morales M. A., Remaud-Simeon M., Pizzut S., Sarçabal P., Willemot R-M., Monsan P. (2000): Sequence analysis of the gene encoding alternansucrase, a sucrose glucosyltransferase from Leuconostoc mesenteroides NRRL B-1355. FEMS Microbilogy Letters, 182: 81-85. p. http://dx.doi.org/10.1111/j.1574$\underline{6968.2000 . t b 08878 . x}$

ASHIDA H., Ozawa H., Fujita K., Suzuki S., Yamamoto K. (2010): Synthesis of mucin-type $O$-glycopeptides and oligosaccharides using transglycosylation and reverse-hydrolysis activities of Bifidobacterium endo- $\alpha-\mathrm{N}-$ acetylgalactosaminidase. Glycoconjugate Journal, 27 (1): 125-132. p. http://dx.doi.org/10.1007/s10719-009-9247$\underline{8}$

ASLAN Y., Tanriseven A. (2007): Immobilization of Pectinex Ultra SP-L to produce galactooligosaccharides. Journal of Molecular Catalysis B: Enzymatic, 45: 73-77. p. http://dx.doi.org/10.1016/j.molcatb.2006.12.005

Athanasopoulos V. I., Niranjan K., Rastall R. A. (2004): Regioselective synthesis of mannobiose and mannotriose by reverse hydrolysis using a novel 1,6- $\alpha$-D-mannosidase from Aspergillus phoenicis. Journal of Molecular Biocatalysis B: Enzymatic, 27 (4-6): 215-219. p. http://dx.doi.org/10.1016/j.molcatb.2003.12.001

AuricChio F., Bruni C. B. (1967): Purification of an acid $\alpha$-glucosidase by dextran-gel filtration. Biochemical Journal, 105: 35-38. p.

BAILEY A. J., Paul R. G., Knott L. (1998): Mechanisms of maturation and ageing of collagen. Mechanisms of Ageing and Development, 106 (1-2): 1-56. p. http://dx.doi.org/10.1016/S0047-6374(98)00119-5

Balken J. A. M., van Dooren J. G. M., van den Tweel W. J. J., Kamphuis J., Meijer E. M. (1991): Production of 1 kestose with intact mycelium of Aspergillus phoenicis containing sucrose- $1^{\mathrm{F}}$-frucotsyltransferase. Applied Microbiology and Biotechnology, 35: 215-221. p. http://dx.doi.org/10.1007/BF00184689

BALOGH T., Boross L., Kosáry J. (2004): Novel reaction systems for the synthesis of O-glucosides by enzymatic reverse hydrolysis. Tetrahedron, 60: 679-682. p. http://dx.doi.org/10.1016/j.tet.2003.10.098

BeKERS M., Upite D., Kaminska E., Laukevics J., Grube M., Vigants A., Linde R. (2005): Stability of levan produced by Zymomonas mobilis. Process Biochemistry, 40: 1535-1539. p. http://dx.doi.org/10.1016/j.procbio.2004.01.052 
Beratis N. G., Labadie G. U., Hirschhorn K. (1978): Characterization of the molecular defect in infantile and adult acid alpha-glucosidase deficiency fibroblasts. The Journal of Clinical Investigation, 62 (6): 1264-1274. p. http://dx.doi.org/10.1172/JCI109247.

BIEDENDIECK R. (2007): Bacillus megaterium: Versatile tool for production, secretion and purification of recombinant proteins. Phd. értekezés, TU Braunschweig

BODE L. (2006): Recent advances on structure, metabolism, and function of human milk oligosaccharides. Journal of Nutrition, 136 (8): 2127-2730. p.

Bojarová P., Petrásková L., Ferrandi E. E., Monti D., Pelantová H., Kuzma M., Simerská P., Křen V. (2007): Glycosyl azides - An alternative way to disaccharides. Advanced synthetic Catalysis, 349: 1514 - 1520 . p. http://dx.doi.org/10.1002/adsc.200700028

BouHNIK Y., Vahedi K., Achour L., Attar A., Salfati J., Pochart P., Marteau P., Flourie B., Bornet F., Rambaud J-C. (1999): Short-chain fructo-oligosaccharide administration dose-dependently increases fecal bifidobacteria in healthy humans. Journal of Nutrition, 129 (1): 113-116. p.

BOUNIAS M. (1980): N-(1-naphthyl)-ethylenediamine dihydrochloride as a new reagent for nanomole quantification of sugars on thin layer plates by a mathematical calibration process. Analytical Biochemistry, 106: 291-295. p. http://dx.doi.org/10.1016/0003-2697(80)90523-0

BRADFORD M. M. (1976): A rapid and sensitive method for thequantitation of microgram quantities of protein utilizing the principle of protein-dye binding. Analytical Biochemistry, 72: 248. p. http://dx.doi.org/10.1016/00032697(76)90527-3

BRETON C., Šnajdrová L., Jeanneau C., Koča J., Imberty A. (2006): Structures and mechanism of glycosyltransferases. Glycobiology, 16 (2): 29-37. p. http://dx.doi.org/10.1093/glycob/cwj016

BROWNLEE M. (1992): Glycation and diabetic complications. Diabetes, 43 (6): $836-841 . \quad$ p. http://dx.doi.org/10.2337/diab.43.6.836

BRUINS M. E., Strubel M., van Lieshout J. F. T., Janssen A. E. M., Boom R. M. (2003a): Oligosaccharide synthesis by the hyperthermostable $\beta$-glucosidase from Pyrococcus furiosus: kinetics and modelling. Enzyme and Microbial Technology, 33 (1): 3-11. p. http://dx.doi.org/10.1016/S0141-0229(03)00096-6

Bruins M. E., Thewessen A. J. H., Janssen A. E. M., Boom R. M. (2003b): Enzyme inactivation due to Maillard reactions during oligosaccharide synthesis by a hyperthermophilic glycosidase: influence of enzyme immobilisation. Journal of Molecular Catalysis B: Enzymatic, 21 (1-2): 31-34. p. http://dx.doi.org/10.1016/S1381$\underline{1177(02) 00131-5}$

BUCHHOLZ K., Noll-Borchers M., Schwengers D. (1998): Production of leucrose by dextransucrase. Starch, 50 (4): 164-172. p. http://dx.doi.org/10.1002/(SICI)1521-379X(199804)50:4<164::AID-STAR164>3.0.CO;2-J

Cabrera J. C., Van Cutsem P. (2005): Preparation of chitooligosaccharides with degree of polymerization higher than 6 by acid or enzymatic degradation of chitosan. Biochemical Engineering Journal, 25 (2): 165-172.p. http://dx.doi.org/10.1016/j.bej.2005.04.025

CACELA C., Hincha D. K. (2006): Monosaccharide composition, chain length and linkage type influence the interactions of oligosaccharides with dryphosphatidylcholine membranes. Biochimica et Biophysica Acta (BBA) Biomembranes, 1758 (5): 680-691. p. http://dx.doi.org/10.1016/j.bbamem.2006.04.005

CAMPbell J. M., Fahey G. C., Bryan W. W. (1997): Selected indigestible oligosaccharides affect large bowel mass, cecal and fecal short-chain fatty acids, $\mathrm{pH}$ and microflora in rats. Journal of Nutrition, 127 (1): 130-136. p.

CANedo M., Jimenez-Estrada M., Cassani J., López-Munguía A. (1999): Production of maltosylfructose (erlose) with levansucrase from Bacillus subtilis. Biocatalysis and Biotransformation, 16: $475-485 . \quad \mathrm{p}$. http://dx.doi.org/10.3109/10242429909015223

CARDelle-Cobas A., Martínez-Villaluenga C., Sanz M. L., Montilla A. (2009): Gas chromatographic-mass spectrometric analysis of galactosyl derivatives obtained by the action of two different $\beta$-galactosidases. Food Chemistry, 114 (3): 1099-1105. p. http://dx.doi.org/10.1016/j.foodchem.2008.10.057

Cardelle-Cobas A., Corzo N., Martínez-Villaluenga C., Olano A., Villamiel M. (2011): Effect of reaction conditions on lactulose-derived trisaccharides obtained by transgalactosylation with $\beta$-galactosidase of Kluyveromyces lactis. European Food Research and Technology, 233: 89-94. p. http://dx.doi.org/10.1007/s00217-011-1496-7

Cardelle-Cobas A., Martínez-Villaluenga C., Villamiel M., Olano A., Corzo N. (2008): Synthesis of oligosaccharides derived from lactulose and Pectinex Ultra SP-L. Journal of Agricultural Food Chemistry, 56 (9): 3328-3333. p. http://dx.doi.org/10.1021/jf073355b

Carvalheiro F., Esteves M. P., ParajoJ. C., Pereira H., Gírio F. M. (2004): Production of oligosaccharides by autohydrolysis of brewery's spent grain. Bioresource Technology, 91: 93-100. p. http://dx.doi.org/10.1016/S0960$\underline{\text { 8524(03)00148-2 }}$

CASElato De Sousa V. M., dos Santos E. F., Sgarbieri V. C. (2011): The importance of prebiotics in functional foods and clinical practice. Food and Nutrition Sciences, 2: 133-144. p. http://dx.doi.org/10.4236/fns.2011.22019

Chambert R., Treboul G., Dedonder R. (1974): Kinetic studies of levansucrase from Bacillus subtilis. European Journal of Biochemistry, 41 (2): 285-300. p. http://dx.doi.org/10.1111/j.1432-1033.1974.tb03269.x

Chen H., Liu L-J., Zhu J-J., Xu B., Li R. (2010): Effect of soybean oligosaccharides on blood lipid, glucose levels and antioxidant enzymes activity in high fat rats. Food chemistry, 119 (4): 1633-1636. p. http://dx.doi.org/10.1016/j.foodchem.2009.09.056 
CHEN X., Xia W., Yu X. (2005): Purification and characterization of two types of chitosanase from Aspergillus sp. CJ22-326. Food Research International, 38 (3): 315-322. p. http://dx.doi.org/10.1016/j.foodres.2004.04.012.

Chen Z-J., Suzaki E., Morino-Kohno E., Kataoka K. (1993): A histochemical study on glycoconjugates in epithelial cells in the distal colonic mucosa of adult and developing mice. Archives of Histology and Cytology, 56 (1): $101-$ 108. p. http://dx.doi.org/10.1679/aohc.56.101

ChI Z-M., Zhang T., Cao T-S., Liu X-Y., Cui W., Zhao C-H. (2011): Biotechnological potential of inulin for bioprocesses. Bioresource Technology, 102: 4295-4303. p. http://dx.doi.org/10.1016/j.biortech.2010.12.086

Chitradon L., Mahakhan P., Bucke C. (2000): Oligosaccharide synthesis by reversed catalysis using $\alpha$-amylase from Bacillus licheniformis. Journal of Molecular Catalysis B: Enzymatic, 10 (1-3): 273-280. p. http://dx.doi.org/10.1016/S1381-1177(00)00110-7

ChludzinsK A. M., Germaine G. R., Schachtele C. F. (1974): Purification and properties of dextransucrase from Streptococcus mutans. Journal of Bacteriology, 118 (1): 1-7. p.

Chо Y. J., Sinha J., Park J. P., Yun J. W. (2001): Production of inulooligosaccharides from chicory extract by endoinulinase from Xanthomonas oryzae No. 5. Enzyme and Microbial Technology, 28: 439-445. http://dx.doi.org/10.1016/S0141-0229(00)00341-0

Cobucci-Ponzano B., Conte F., Bedini E., Corsaro M. M., Parrilli M., Sulzenbacher G., Lipski A., Piaz F. D., Lepore L., Rossi M., Moracci M. (2009): $\beta$-Glycosyl azides as substrates for $\alpha$-glycosynthases: preparation of efficient $\alpha$-L-fucosynthases. Chemistry and Biology, $16 \quad$ (10): 1097-1108. p. http://dx.doi.org/10.1016/j.chembiol.2009.09.013

Combo A. M. M., Aguedo M., Goffin D., Wathelet B., Paquot M. (2012): Enzymatic production of pectic oligosaccharides from polygalacturonic acid with commercial pectinase preparations. Food and Bioproducts Processing, 90 (3): 588-596. p. http://dx.doi.org/10.1016/j.fbp.2011.09.003

Coutinho P. M., Deleury E., Davies G. J., Henrissat B. (2003): An evolving hierarchical family classification for glycosyltransferases. Journal of Molecular Biology, 328: 307-317. p. http://dx.doi.org/10.1016/S0022$\underline{2836(03) 00307-3}$

Coutinho P. M., Henrissat B. (1999): Carbohydrate-active enzymes server at URL: http://afmb.cnrsmrs.fr/CAZY/index.html

Couturier M., Roussel A., Rosengren A., Leone P., Stälbrand H., Berrin J-G. (2013): Structural and biochemical analyses of glycoside hydrolase families 5 and $26 \beta-(1,4)$-mannanases from Podospora anserina reveal differences upon manno-oligosaccharide catalysis. The Journal of Biological Chemistry, 288: 14624-14635. p. http://dx.doi.org/10.1074/jbc.M113.459438

CRITTEnden R. G., Playne M. J. (1996): Production, properties and applications of food-grade oligosaccharides. Trends in Food Science \& Technology, 7: 353-361. p. http://dx.doi.org/10.1016/S0924-2244(96)10038-8

CritTenden R., Playne M. J. (2009): Prebiotics. In: Lee Y. K. \& Salminen S. (Szerk.): Handbook of Probiotics and Prebiotics, John Wiley \& Sons Inc., Hoboken, New Jersey, 533-582. p.

Crout D. H. G., Vic G. (1998): Glycosidases and glycosyl transferases in glycoside and oligosaccharide synthesis. Current Opinion in Chemical Biology, 2 (1): 98-111. p. http://dx.doi.org/10.1016/S1367-5931(98)80041-0

CSANÁDI Zs., Sisak Cs. (2006): Immobilization of Pectinex SP-L pectinase and its application to production of fructo-oligosaccharides. Acta Alimentaria, 35: 205-212. p. http://dx.doi.org/10.1556/AAlim.35.2006.2.7

D'Enfert C., Bonini B. M., Zapella P. D. A., Fontaine T., Da Silva A. M., Terenzi H. F. (1999): Neutral trehalases catalyse intracellular trehalose breakdown in the filamentous fungi Aspergillus nidulans and Neurospora crassa. Molecular Microbiology, 32 (3): 471-483. p. http://dx.doi.org/10.1046/j.1365-2958.1999.01327.x

D'ENFERT C., Fontaine T. (1997): Molecular characterization of the Aspergillus nidulans treA gene encoding an acid trehalase required for growth on trehalose. Molecular Microbiology, 24 (1): 203-216. p. http://dx.doi.org/10.1046/j.1365-2958.1997.3131693.x

DAHLQVIST A. (1960): Characterization of hog intestinal trehalase. Acta Chemica Scandinavica, 14: 9-16. p.

DALL'ACQUA W., Carter P. (2000): Substrate-assisted catalysis: Molecular basis and biological significance. Protein Science, 9: 1-9. p. http://dx.doi.org/10.1110/ps.9.1.1

DE VReSE M., Marteau P. R. (2007): Probiotics and prebiotics: effects on diarrhea. Journal of Nutrion, 137 (3): 803-811. p.

DÉKÁNY Gy., Champion E., Schroven A., Hederos M. (2012): Method for generating human milk oligosaccharides (HMOs) or precursors thereof. US 20140234912 A1

Delgado G. T. C., Tamashiro W. M. S. C., Junior M. R. M., Moreno Y. M. F., Pastore G. M. (2011): The putative effects of prebiotics as immunomodulatory agents. Food Research International, 44: 3167-3173. p. http://dx.doi.org/10.1016/j.foodres.2011.07.032

DEL-VAL M. I., Hill Jr C. G., Jimenez-Barbero J., Otero C. (2001): Selective enzymatic synthesis of 6'-galactosyl lactose by Pecitnex ultra SP in water. Biotechnology Letters, 23: 1921-1924. p. http://dx.doi.org/10.1023/A:1013794019371

DELZenNe N. M. (2003): Oligosaccharides: state of art. Proceedings of the Nutrition Society, 62: 177-182. p. http://dx.doi.org/10.1079/PNS2002225

DELZENNE N. M., Roberfroid M. R. (1994): Physiological effects of non-digestible oligosaccharides. LWT - Food Science and Technology, 27: 1-6. p. http://dx.doi.org/10.1006/fstl.1994.1001 
DEMUTH K., Jördening H-J., Buchholz K. (2002): Oligosaccharide synthesis by dextransucrase: new unconventional acceptors. Carbohydrate Research, 337 (20): 1811-1820. p. http://dx.doi.org/10.1016/S0008-6215(02)00272-0

DiGabriele A. D., Lax I., Chen D. I., Svahn C. M., Jaye M., Schlessinger J., Hendrickson W. A. (1998): Structure of a heparin-linked biologically active dimer of fibroblast growth factor. Nature, 393: 812-817. p. http://dx.doi.org/10.1038/31741

Dols M., Remaud-Simeon M., Willemot R-M., Demuth B., Jördening H-J., Buchholz K., Monsan P. (1999): Kinetic modeling of oligosaccharide synthesis catalyzed by Leuconostoc mesenteroides NRRL B-1299 dextransucrase. Biotechnology and Bioengineering, 63 (3): 308-315. p. http://dx.doi.org/10.1002/(SICI)10970290(19990505)63:3<308::AID-BIT7>3.0.CO;2-2

DROUET P., Zhang M., Legoy M. D. (1994): Enzymatic synthesis of alkyl $\beta$-D-xylosides by transxylosylation and reverse hydrolysis. Biotechnology and Bioengineering, 43: 1075-1080. p. http://dx.doi.org/10.1002/bit.260431110

DuAn K. J., Chen J. S., Sheu D. C. (1994): Kinetic studies and mathematical model for enzymatic production of fructooligosaccharides from sucrose. Enzyme and Microbial Technology, 16 (4): 334-339. p. http://dx.doi.org/10.1016/0141-0229(94)90176-7

DuniCAN L. K., Seeley H. W. (1963): Temperature-sensitive dextransucrase synthesis by a Lactobacillus. Journal of Bacteriology, 86: 1079-1083. p.

ENRíQuez-GUEvara E. A., Aispuro-Hernández E., Vargas-Arispuro I., Martínez-Téllez M. Á. (2010): Cell wall oligosaccharine derivatives: biological activity and participation in the response of plant defense. Revista Mexicana de Fitopatología, 28 (2): 144-155. p.

Euzenat O., Guibert A., Combes D. (1997): Production of fructo-oligosaccharides by levansucrase from Bacillus subtilis C4. Process Biochemistry, 32 (3): 237-243. p. http://dx.doi.org/10.1016/S0032-9592(96)00058-1

FEKETE Cs. A., KISS L. (2012): Purification and characterization of a recombinant $\beta$-D-xylosidase from Thermobifida fusca TM51. The Protein Journal, 31:641-650. p. http://dx.doi.org/10.1007/s10930-012-9440-7

FERNANDEZ-Rodrigez M., Cardelle -Cobas A., Villamiel M., Banga J. R. (2011): Detailed kinetic model describing new oligosaccharides synhtesis using different $\beta$-galactosidases. Journal of Biotechnology, 153: 116124. p. http://dx.doi.org/10.1016/j.jbiotec.2011.03.012

Ferrer M., Golyshina O. V., Plou F. J., Timmis K. N., Golyshin P. N. (2005): A novel $\alpha$-glucosidase from the acidophilic archaeon Ferroplasma acidiphilum strain $\mathrm{Y}$ with high transglycosylation activity and an unusual catalytic nucleophile. Biochemical Journal, 391: 269-276. p. http://dx.doi.org/10.1042/BJ20050346

Fialová P., Carmona A. T., Robina I., Ettrich R., Sedmera P., Prikřylová V., Petrasková-husáková L, Křen V. (2005): Glycosyl azide - a novel substrate for enzymatic transglycosylations. Tetrahedron Letters, 46: 8715-8718. p. http://dx.doi.org/10.1016/j.tetlet.2005.10.040

FILICE M., Marciello M. (2013): Enzymatic synthesis of oligosaccharides: A powerful tool for a sweet challenge. Current Organic Chemistry, 17: 701-718. p. http://dx.doi.org/10.2174/1385272811317070006

GAGNEUX P., Varki A. (1999): Evolutionary considerations in relating oligosaccharide diversity to biological function. Glycobiology, 9 (8): 747-755. p.

GAMA F. M., Mota M. (1998): Cellulases for oligosaccharide synthesis: a preliminary study. Carbohydrate Polymers, 37: 279-281. p. http://dx.doi.org/10.1016/S014486179800071X

GHAzI I., Fernandez-Arrajo L., Garcia-Arellano H., Ferrer M., Ballesteros A., Plou J. F. (2007): Purification and kinetic characterization of a fructosyltransferase from Aspergillus aculeatus. Journal of Biotechnology, 128: 204211. p. http://dx.doi.org/10.1016/j.jbiotec.2006.09.017

Ghazi I., Fernandez-Arrojo L., Gómez de Segura A., Alcalde M., Plou F. J., Ballesteros A. (2006): Beet sugar syrup and molasses as low-cost feedstock for the enzymatic production of fructo-oligosaccharides. Journal of Agricultural and Food Chemistry, 54 (8): 2964-2968. p. http://dx.doi.org/10.1021/jf053023b

GiESE E. C., Barbosa A. M., Dekker R. F. H. (2010): Pathways to bioactive oligosaccharides: biological functions and potential applications. In: Ito R., Matsuo Y. (Szerk.): Handbook of Carbohydrate Polymers, Nova Science Publishers Inc., 279-309. p.

Gimeno-Perez M., Santos-Moriano P., Fernández-Arrojo L., Poveda A., Jiménez-Barbero J., Ballesteros A. O., Fernández-Lobato M., Plou F. J. (2014): Regioselective synthesis of neo-erlose by the $\beta$-fructofuranosidase from Xanthophyllomyces dendrorhous. Process Biochemistry, 49: 423-429. p. http://dx.doi.org/10.1016/j.procbio.2013.12.018

GIRI, K. V., Nigam, V. N., Srinivasan, K. S. (1954): Synthesis of oligosaccharides during enzymatic hydrolysis of cellobiose by Aspergillus flavus. Nature, 173 (4411): 953-954. p.

Goncalves B. C. M., Baldo C., Celliogi M. A. P. C. (2015): Levan and levansucrase- A mini review. International Journal of Scientific \& Technology Research, 4 (5): 100-104. p.

Gosling A., Stevensa G. W., Barberc A. R., Kentisha S. E., Gras S. L. (2010): Recent advances refining galactooligosaccharide production from lactose. Food Chemistry, 121: 307-318. p. http://dx.doi.org/10.1016/j.foodchem.2009.12.063

Goulas A., Tzortzis G., Gibson G. R. (2007): Development of a process for the production and purification of $\alpha$ and $\beta$-galactooligosaccharides from Bifidobacterium bifidum NCIMB 41171. International Dairy Journal, 17 (6): 648-656. p. http://dx.doi.org/10.1016/j.idairyj.2006.08.010 
Goulas T., Goulas A., Tzortzis G., Gibson G. R. (2009): A novel $\alpha$-galactosidase from Bifidobacterium bifidum with transgalactosylating properties: gene molecular cloning and heterologous expression. Applied Microbiology and Biotechnology, 82 (3): 471-477. p. http://dx.doi.org/10.1007/s00253-008-1750-5

Guerrero C., Vera C., Illanes A. (2013): Optimisation of synthesis of oligosaccharides derived from lactulose (fructosyl-galacto-oligosaccharides) with $\beta$-galactosidases of different origin. Food Chemistry, 138 (4): 2225 2232. p. http://dx.doi.org/10.1016/j.foodchem.2012.10.128

Guffanti A. A., Corpe W. A. (1976): Partial purification and characterization of alpha-glucosidase from Pseudomonas fluorescens W. Archives of Microbiology, $107 \quad$ (3): 269-276. p. http://dx.doi.org/10.1007/BF00425338

GüNTHER W., Kunz H. (1992): Synthesis of $\beta$-D-mannosides from $\beta$-D-glucosides via an intramolecular SN2 reaction at C-2. Carbohydrate Research, 228 (1): 217-241. p. http://dx.doi.org/10.1016/S0008-6215(00)90561-5

GYÉMÁNT Gy., Tóth A., Bajza I., Kandra L., Lipták A. (2001): Identification and structural analysis of synthetic oligosaccharides of Shigella sonnei using MALDI-TOF MS. Carbohydrate Research, 334: 315-322. p. http://dx.doi.org/10.1016/S0008-6215(01)00197-5

HANCOCK S. M., Vaughan M. D., Withers S. G. (2006): Engineering of glycosidases and glycosyltransferases. Current Opinion in Chemical Biology, 10: 509-519. p. http://dx.doi.org/10.1016/j.cbpa.2006.07.015.

HANG Y. D., Woodams E. E. (1995): Fructosyl-transferase activity of commercial enzyme preparations used in fruit juice processing. Biotechnology Letters, 17: 741-744. p. http://dx.doi.org/10.1007/BF00130361

HANG Y. D., Woodams E. E. (1996): Optimization of enzymatic production of fructo-oligosaccharides from sucrose. LWT-Food Science and Technology, 29: 578-580. p. http://dx.doi.org/10.1006/fstl.1996.0089

Hashimoto H., Katayama C., Goto M., Okinaga T., Kitahata S. (1995): Transgalactosylation catalyzed by $\alpha$ galactosidase from Candida guilliermondii H-404. Bioscience, Biotechnology and Biochemistry, 59 (4): $619-623$. p. http://dx.doi.org/10.1271/bbb.59.619

Hashimoto H., Yamashita A., Ikura K., Katayama C., Goto M., Yasuno S., Kamei M., Kitahata S. (2001): Production of the positional isomers of alpha-galactobiose by the reverse reaction of alpha-galactosidase from Candida guilliermondii H-404. Journal of Applied Glycoscience, 48: 3. p.

HAYASHI S., Hayashi T., Takasaki Y., Imada K. (1994): Purification and properties of glucosyltransferase from Aureobasidium. Journal of Industrial Microbiology, 13 (1): 5-9. p. http://dx.doi.org/10.1007/BF01569655

HEINCKE K., Demuth B., Jördening H-J., Buchholz K. (1999): Kinetics of the dextransucrase acceptor reaction with maltose-experimental results and modeling. Enzyme and Microbial Technology, 24 (8-9): 523-534. p. http://dx.doi.org/10.1016/S0141-0229(98)00150-1

Hellmuth H., Wittrock S., Kralj S., Dijkhuizen L., Hofer B., Seibel J. (2008): Engineering the glucansucrase GTFR enzyme reaction and glycosidic bond specificity: toward tailor-made polymer and oligosaccharide products. Biochemistry, 47: 6678-6684. p. http://dx.doi.org/10.1021/bi800563r

HenNeT T. (2002): The galactosyltransferase family. Cellular and Molecular Life Sciences, 59 (7): 1081-1095. p. http://dx.doi.org/10.1007/s00018-002-8489-4

HeSTRIN S., Feingold D. S., Avigad G. (1956): The mechanism of polisaccharide production from sucrose. 3. Donor-acceptor specificity of levansucrase from Aerobacter levanicum. Biochemical Journal, 64 (2): 340-351. p.

Hirayama M. (2002): Novel physiological functions of oligosaccharides. Pure and Applied Chemistry, 74: 12711279. p. http://dx.doi.org/10.1351/pac200274071271

HofFMeister D., Wilkinson B., Foster G., Sidebottom P. J., Ichinose K., Bechthold A. (2002): Engineered urdamycin glycosyltransferases are broadened and altered in substrate specificity. Chemistry and Biology, 9 (3): 287-295. p. http://dx.doi.org/10.1016/S1074-5521(02)00114-X

Homann A. (2009): En route to tailor-made oligosaccharides- chemoenzymatic synthesis and physiological functions of novel carbohydrate structures. PhD. értekezés, TU Braunschweig

HomanN A., Biedendieck R., Götze S., Jahn D., Seibel J. (2007): Insights into polymer versus oligosaccharide synthesis: mutagenesis and mechanistic studies of a novel levansucrase from Bacillus megaterium. Biochemical Journal, 407: 189-198. p. http://dx.doi.org/10.1042/BJ20070600

HomanN A., Seibel J. (2009): Towards tailor-made oligosaccharides- chemoenzymatic approaches by enzyme and substrate engineering. Applied Microbiology and Biotechnology, 83: 209-216. p. http://dx.doi.org/10.1007/s00253009-1989-5

HONDA Y., Kitaoka M. (2006): The first glycosynthase derived from an inverting glycoside hydrolase. Journal of Biological Chemistry, 281: 1426-1431. p. http://dx.doi.org/10.1074/jbc.M511202200

HoRIKOSHI K., Ikeda Y. (1966): Trehalase ín conidia of Aspergillus oryzae. Journal of Bacteriology, 91 (5): 1883 1887. p.

Hsu C. A., Lee S. L., Chou C. C. (2007): Enzymatic production of galactooligosaccharides by $\beta$-galactosidase from Bifidobacterium longum BCRC 15708. Journal of Agricultural and Food Chemistry, 55 (6): 2225-2230. p. http://dx.doi.org/10.1021/jf063126

HU J., Jin Z-Y., Wang J. (2007): Extraction and purification of inulin from Jerusalem artichoke. Food Science and Technology, 4. p.

Hu Y., Walker S. (2002): Remarkable structural similarities between diverse glycosyltransferase. Chemistry and biology, 9 (12): 1287-1296. p. http://dx.doi.org/10.1016/S1074-5521(02)00295-8 
Hung M. N., Lee B. (2002): Purification and characterization of a recombinant $\beta$-galactosidase with transgalactosylation activity from Bifidobacterium infantis HL96. Applied Microbiology and Biotechnology, 58 (4): 439-445. p. http://dx.doi.org/10.1007/s00253-001-0911-6

Hung V. S., Hatada Y., Goda S., Lu J., Hidaka Y., Li Z., Akita M., Ohta Y., Watanabe K., Matsui H., Ito S., Horikoshi K. (2005): $\alpha$-Glucosidase from a strain of deep-sea Geobacillus: A potential enzyme for the biosynthesis of complex carbohydrates. Applied Microbiology and Biotechnology, 68 (6): 757-765. p. http://dx.doi.org/10.1007/s00253-005-1977-3

ICHIKAWA Y., Look G. C., Wong C. (1992): Enzyme-catalyzed oligosaccharide synthesis. Analytical Biochemistry, 202: 215-238. p. http://dx.doi.org/10.1016/0003-2697(92)90099-S

JAhN M., Stoll D., Warren R. A. J., Szabó L., Singh P., Gilbert H. J., Ducros V. M-A., Davies G. J., Withers S. G. (2003): Expansion of the glycosynthase repertoire to produce defined manno-oligosaccharides. Chemical Communications, 12: 1327-1329. p. http://dx.doi.org/10.1039/B302380J

JENTOFT N. (1990): Why are proteins O-glycosylated? Trends in Biochemical Sciences, 15 (8): 291-294. p. http://dx.doi.org/10.1016/0968-0004(90)90014-3

JoHANSSON E., Hedbys L., Larsson P-O. (1986): Synthesis of mannose oligosaccharides via reversal of the $\alpha$ mannosidase reaction. Biotechnology Letters, 8 (6): 421-424. p. http://dx.doi.org/10.1007/BF01026746

JoHANSSON E., Hedbys L., Mosbach K., Larsson P-O. (1989): Studies of the reversed $\alpha$-mannosidase reaction in high concentrations of mannose. Enzyme and Microbial Technology, 11 (6): $347-352 . \quad$. http://dx.doi.org/10.1016/0141-0229(89)90018-5

JOHNSON K. F. (1999): Synthesis of oligosaccharides by bacterial enzymes. Glycoconjugate Journal, 16: 141-146. p. http://dx.doi.org/10.1007/978-1-4615-5257-4_5

Jorge J. A., Polizeli M. de L. T. M., Thevelein J. M., Terenzi H. F. (1997): Trehalases and trehalose hydrolysis in fungi. FEMS Microbiology Letters, 154 (2): 165-171. p. http://dx.doi.org/10.1111/j.1574-6968.1997.tb12639.x

KANG M-S., Okuyama M., Mori H., Kimura A. (2009): The first $\alpha$-1,3-glucosidase from bacterial origin belonging to glycoside hydrolase family $31 . \quad$ Biochimie, $91 \quad$ (11-12): $1434-1442 . \quad$ p. http://dx.doi.org/10.1016/j.biochi.2009.07.018

KANEKO T., Kohmoto T., Kikuchi H., Shiota M., Iino H., Mitsuoka T. (1994): Effects of Isomaltooligosaccharides with different degrees of polymerization on human fecal bifidobacteria. Bioscience, Biotechnology and Biochemistry, 58 (12): 2288-2290. p. http://dx.doi.org/10.1271/bbb.58.2288

KAUR N., Gupta A. K. (2002): Applications of inulin and oligofructose in health and nutrition. Journal of Biosciences, 27: 703-714. p. http://dx.doi.org/10.1007/BF02708379

KIM D. H., Choi Y. J., Song S. K., Yun J. W. (1997): Production of inulo-oligosaccharides using endo-inulinase from a Pseudomonas sp. Biotechnology Letters, 19 (4): 369-371. p. http://dx.doi.org/10.1023/A:1018311219788

KIM J-H., Lee D-H., Lee J-S. (2001): Production of galactooligosaccharide by $\beta$-galactosidase from Kluyveromyces maxianus var lactis OE-20. Biotechnology and Bioprocess Engineering, 6 (5): 337-340. p. http://dx.doi.org/10.1007/BF02933002

KIM S., Kim W., Hwang I.K. (2003): Optimization of the extraction and purification of oligosaccharides from defatted soybean meal. International Journal of Food Science and Technology, 38: 337-342. p. http://dx.doi.org/10.1046/j.1365-2621.2003.00679.x

KIM S-K., Rajapakse N. (2005): Enzymatic production and biological activities of chitosan oligosaccharides (COS): A review. Carbohydrate Polymers, 62 (4): 357-368. p. http://dx.doi.org/10.1016/j.carbpol.2005.08.012

Kim T. U., GU B. G., JeOng J. Y., BYUn S. M., SHIN Y. C. (1995): Purification and characterization of a maltotetraose-forming alkaline $\alpha$-amylase from an alkalophilic Bacillus strain, GM8901. Applied and Environmental Microbiology, 61 (8): 3105-3112. p.

KobaYASHI T., Adachi S., Nakanishi K., Matsuno R. (2000): Synthesis of alkyl glycosides through $\beta$-glucosidasecatalyzed condensation in an aqueous-organic biphasic system and estimation of the equilibrium constants for their formation. Journal of Molecular Catalysis B: Enzymatic, 11 (1): 13-21. p. http://dx.doi.org/10.1016/S1381$\underline{1177(00) 00190-9}$

KobaYASHI T., Kanai H., Hayashi T., Akiba T., Akaboshi R., Horikoshi K. (1992): Haloalkaliphilic maltotrioseforming $\alpha$-amylase from the Archaebacterium Natronococcus sp. strain Ah-36. Journal of Bacteriology, 174 (11): 3439-3444. p.

Kosáry J., Stefanovits-Bányai É., Boross L. (1998): Reverse hydrolytic process for O-alkylation of glucose catalysed by immobilized $\alpha$ - and $\beta$-glucosidases. Journal of Biotechnology, 66: 83-86. $p$. http://dx.doi.org/10.1016/S0168-1656(98)00160-6

KOSHLAND D. E. (1953): Stereochemistry and mechanism of enzymatic reactions. Biological Reviews, 28: $416-436$. p. http://dx.doi.org/10.1111/j.1469-185X.1953.tb01386.x

Kovács I., Bajza I., Hederos M., Dékány Gy., Demkó S., Khanzhin N. (2012): Synthesis of HMO core structures. US201400235850 A1

Krasikov V. V., Karelov D. V., Firsov L. M. (2001): $\alpha$-Glucosidases. Biochemistry (Moscow), 66 (3): 267-281. p. http://dx.doi.org/10.1023/A:1010243611814

KU S., Wei L. S., Steinberg M. P., Nelson A. I., Hymowitz T. (1976): Extraction of oligosaccharides during cooking of whole soybeans. Journal of Food Science, 41 (2): 361-364. p. http://dx.doi.org/10.1111/J.13652621.1976.TB00619.X 
KuHN R. C., Mazutti M. A., Filho F. M. (2012): Kinetic and mass transfer effects for adsorption of glucose, fructose, sucrose and fructooligosaccharides into X zeolite. LWT - Food Science and Technology, 48 (1): $127-133$. p. http://dx.doi.org/10.1016/j.lwt.2012.02.010

Kumar M. N. V. R., Muzzarelli R. A. A., Muzzarelli C., Sashiwa H., Domb A. J. (2004): Chitosan chemistry and pharmaceutical perspectives. Chemical Reviews, 104 (12): 6017-6084. p. http://dx.doi.org/10.1021/cr030441b

KURAKAKE M., Moriyama Y., Sunouchi R., Nakatani S. (2011): Enzymatic properties and transglycosylation of $\alpha$ galactosidase from Penicillium oxalicum SO. Food Chemistry, $126 \quad$ (1): 199-182. p. http://dx.doi.org/10.1016/j.foodchem.2010.10.095

KURIMOTO M., Nishimoto T., Nakada T., Chaen H., Fukuda S., Tsujisaka Y. (1997): Synthesis by an $\alpha$-glucosidase of glycosyl-trehaloses with an isomaltosyl residue. Bioscience, Biotechnology, and Biochemistry, 61 (4): 699-703. p. http://dx.doi.org/10.1271/bbb.61.699

Lehner A., Riedel K., Rattei T., Ruepp A., Frishmann D., Breeuwer P., Diep B., Eberl L., Stephan R. (2006): Molecular characterization of the alpha-glucosidase activity in Enterobacter sakazakii reveals the presence of a putative gene cluster for palatinose metabolism. Systematic and Applied Microbiology, 29 (8): 609-625. p. http://dx.doi.org/10.1016/j.syapm.2006.02.002

Li W., Xiang X., Tang S., Hu B., Tian L., Sun Y., Ye H., Zeng X. (2009): Effective enzymatic synthesis of lactosucrose and its analogues by $\beta$-D-galactosidase from Bacillus circulans. Journal of Agricultural Food Chemistry, 57: 3927-3933. p. http://dx.doi.org/10.1021/jf9002494

LI Y-T., Shetlar M. R. (1964): Galactosyl transfer reactions catalysed by pneumococcal $\alpha$-galactosidase. Archives of Biochemistry and Biophysics, 108 (2): 301-313. p. http://dx.doi.org/10.1016/0003-9861(64)90391-1

LiN S-B., Lin Y-C., Chen H-H. (2009): Low molecular weight chitosan prepared with the aid of cellulase, lysozyme and chitinase: Characterisation and antibacterial activity. Food Chemistry, 116 (1): 47-53. p. http://dx.doi.org/10.1016/j.foodchem.2009.02.002

LOo J. V. (2006): Inulin-type fructans as prebiotics. In: Gibson G. R., Rastall R. A. (Szerk.): Prebiotics: development and application. John Wiley\& Sons Inc, Hoboken NJ, 57-100. p.

Loo J. V., Cummings J., Delzenne N., Englyst H., Franck A., Hopkins M., Kok N., Macfarlane G., Newton D., Quigley M., Roberfroid M., Vliet T., van den Heuvel E. (1999): Functional food properties of non-digestible oligosaccharides: a consensus report from the ENDO project (DGXII AIRII-CT94-1095). British Journal of Nutrition, 81: 121-132. p. http://dx.doi.org/10.1017/S0007114599000252

LULEY-GOEDL C., Nidetzky B. (2010): Carbohydrate synthesis by disaccharide phosphorylases: Reactions, catalytic mechanisms and application in the glycosciences. Biotechnology Journal, 5 (12): 1324-1338. p. http://dx.doi.org/10.1002/biot.201000217

Lunina N. A., Berezina O. V., Veith B., Zverlov V. V., Vorobjeva I. P., Chekanovskaya L. A., Khromov I. S. Raasch C., Liebl W., Velikodvorskaya G. A. (2003): A cluster of Thermotoga neapolitana genes involved in the degradation of starch and maltodextrins: the expression of the $\operatorname{agl\mathrm {B}}$ and aglA genes in E. coli and the properties of the recombinant enzymes. Molecular Biology, 37 (5): 686-694. p. http://dx.doi.org/10.1023/A:1026028825448

MACFARLANE G. T., Macfarlane S. (2007): Models for intestinal fermentation: association between food components, delivery systems, bioavailability and functional interactions in the gut. Current Oponion in Biotechnology, 18: 156-162. p. http://dx.doi.org/10.1016/j.copbio.2007.01.011

МАС̈ H., Volkin D. B., Burke C. J., Middaugh R. (1993): Nature of the interaction of heparin with acidic fibroblast growth factor. Biochemistry, 32: 5480-5489. p. http://dx.doi.org/10.1021/bi00071a026

MACKenZIE L. F., Wang Q., Warren R. A. J., Withers S. G. (1998): Glycosynthases: Mutant glycosidases for oligosaccharide synthesis. Journal of the American Chemical Society, $120(22)$ : 5583-5584. p. http://dx.doi.org/10.1021/ja980833d

MAITIN V. \& Rastall R. A. (2007): Enzymatic synthesis of oligosaccharides: Progress and recent trends. In: Shetty K., Paliyath G., Pometto A. L., Levin R. E. (Szerk.) Functional Foods and Biotechnology, CRC Press, Boca Raton, Florida

MAITIN V., Athanasopoulos V., Rastall R. A. (2004): Synthesis of FimH receptor-active manno-oligosaccharides by reverse hydrolysis using $\alpha$-mannosidases from Penicillium citrinum, Aspergillus phoenicis and almond. Applied Microbiology and Biotechnology, 63: 666-671. p. http://dx.doi.org/10.1007/s00253-003-1416-2

MaITIN V., Rastall R. A. (2004): Enzyme glycation influences product yields during oligosaccharide synthesis by reverse hydrolysis. Journal of Molecular Biocatalysis B: Enzymatic, $30 \quad$ (5-6): 195-202. p. http://dx.doi.org/10.1016/j.molcatb.2004.05.004

MALÁ S., Králová B. (2000): Heterooligosaccharide synthesis catalyzed by $\alpha$-glucosidase from Bacillus stearothermophilus. Journal of Molecular Catalysis B: Enzymatic, $10 \quad$ (6): 617-621. p. http://dx.doi.org/10.1016/S1381-1177(00)00185-5

Martínez-Villaluenga C., Cardelle-Cobas A., Olano A., Corzo N., Villamiel M., Jimeno M. L. (2008): Enzymatic synthesis and identification of two trisaccharides produced from lactulose by transgalactosylation. Journal of Agricultural and Food Chemistry, 56 (2): 557-563. p. http://dx.doi.org/10.1021/jf0721343

MAYER C., Zechel D. L., Reid S. P., Warren R. A. J., Withers S. G. (2000): The E358S mutant of Agrobacterium sp. $\beta$-glucosidase is a greatly improved glycosynthase. FEBS Letters 466 (1): 40-44. http://dx.doi.org/10.1016/S0014-5793(99)01751-2 
MCILVAINE T. C. (1921): A buffer solution for colorimetric comparison. Journal of Biological Chemistry, 49: 183186. p.

Messa oud E. B., Ali M. B., Elleuch N., Masmoudi N. F., Bejar S (2004): Purification and properties of a maltoheptaose- and maltohexaose-forming amylase produced by Bacillus subtilis US116. Enzyme and Microbial Technology, 34 (7): 662-666. p. http://dx.doi.org/10.1016/j.enzmictec.2004.03.002

MinAMI T., Fujiwara T., Ooshima T., Nakajima Y., Hamada S. (1990): Interaction of structural isomers of sucrose in the reaction between sucrose and glucosyltransferases from mutans streptococci. Oral Microbiology and Immunology, 5 (4): 189-194. p. http://dx.doi.org/10.1111/j.1399-302X.1990.tb00644.x

MiYazAWA T., Funazukuri T. (2006): Noncatalytic hydrolysis of guar gum under hydrothermal conditions, Carbohydrate Research, 341: 870-877. p. http://dx.doi.org/10.1016/j.carres.2006.02.014

MONNIER V. M. (2003): Intervention against the Maillard reaction in vivo. Archives of Biochemistry and Biophysics, 419 (1): 1-15. p. http://dx.doi.org/10.1016/j.abb.2003.08.014

Monsan P. F., Auriol D. (2004): Dextran and Glucooligosaccharides, in Neeser J-R., Bruce J. Bioprocess and biotechnology for functional foods and nutraceuticals. Marcel Dekker, Inc.135-150. p.

MONSAN P., Paul F. (1995): Enzymatic synthesis of oligosaccharides. FEMS Microbiology Reviews, 16: 187-192. p. http://dx.doi.org/10.1111/j.1574-6976.1995.tb00165.x

MORACCI M., Trincone A., Rossi M. (2001): Glycosynthases: new enzymes for oligosaccharide synthesis. Journal of Molecular Catalysis B: Enzymatic, 11: 155-163. p. http://dx.doi.org/10.1016/S1381-1177(00)00084-9

Muchmore A. V., Sathymamoorthy N., Decker J., Sherblom A. P. (1990): Evidence that specific high-mannose oligosaccharides can directly inhibit antigen-driven T-cell responses. Journal of Leukocyte Biology, 48: 457-464. p.

Murata T., Akimoto S., Horimoto M., Usui T. (1997): Galactosyl transfer onto p-nitrophenyl $\beta$-D-glucoside using $\beta$-D-galactosidase from Bacillus circulans. Bioscience Biotechnology and Biochemistry, 61 (7): 1118-1120. p. http://dx.doi.org/10.1271/bbb.61.1118

MusSATto S. I., Mancilha I. M. (2007): Non-digestible oligosaccharides: A review. Carbohydrate Polimers, 68: 587-597. p. http://dx.doi.org/10.1016/j.carbpol.2006.12.011

Mutanda T., Wilhelmi B. S., Whiteley C. G. (2008): Response surface methodology: Synthesis of inulooligosaccharides with an endoinulinase from Aspergillus niger. Enzyme and Microbial Technology, 43 (4-5): 362-368. p. http://dx.doi.org/10.1016/j.enzmictec.2008.06.005

Muzzarelli R. A. A., Xia W., Tomasetti M., Ilari P. (1995): Depolymerization of chitosan and substituted chitosans with the aid of a wheat germ lipase preparation. Enzyme and Microbial Technology, 17 (6): 541-545. p. http://dx.doi.org/10.1016/0141-0229(94)00015-J

MüllER G., Kitas E., Wessel H. P. (1995): Novel oligosaccharide mimetics by solid-phase synthesis. Journal of the Chemical Society, 23: 2425-2426. p. http://dx.doi.org/10.1039/C39950002425

NAgarajan D. R., Rajagopalan G., Krishnan C. (2006): Purification and characterization of a maltooligosaccharide-forming $\alpha$-amylase from a new Bacillus subtilis KCC103. Applied Microbiology and Biotechnology, 73 (3): 591-597. p. http://dx.doi.org/10.1007/s00253-006-0513-4

NaKaI H., Hachem M. A., Petersen B. O., Westphal Y., Mannerstedt K., Baumann M. J., Dilokpimol A., Schols H. A., Duus J., Svensson B. (2010): Efficient chemoenzymatic oligosaccharide synthesis by reverse phosphorolysis using cellobiose phosphorylase and cellodextrin phosphorylase from Clostridium thermocellum. Biochimie, 92 (12): 1818-1826. p. http://dx.doi.org/10.1016/j.biochi.2010.07.013

NAKaI H., Kitaoka M., Svensson B., Ohtsubo K. (2013): Recent development of phosphorylases possessing large potential for oligosaccharide synthesis. Current Opinion in Chemical Biology, 17 (2): 301-309. p. http://dx.doi.org/10.1016/j.cbpa.2013.01.006

NAKAJIMA Y., Nishio K. (1993): 'Isomaltulose' in oligosaccharides. Production, properties and applications. Japanese Technology Reviews, 3 (2): 107-1 17. p.

Nakamura T., Shitara A., Matsuda S., Matsuo T., Suiko M., Ohta K. (1997): Production, purification and properties of an endoinulinase of Penicillium sp. TN-88 that liberates inulotriose. Journal of Fermentation and Bioengineering, 84 (4): 313-318. p. http://dx.doi.org/10.1016/S0922-338X(97)89250-1

Nakano H., Murakami H., Shizuma M., Kiso T., de Araujo T. L., Kitahata S. (2000): Transfructosylation of thiol group by $\beta$-fructofuranosidases. Bioscience, Biotechnology, and Biochemistry, 64 (7): 1472-1476. p. http://dx.doi.org/10.1271/bbb.64.1472

NAKAO M., Nakayama T., Kakudo A., Inohara M., Harada M., Omura F., Shibano Y. (1994): Structure and expression of a gene coding for thermostable $\alpha$-glucosidase with a broad substrate specificity from Bacillus sp. SAM1606. European Journal of Biochemistry, 220 (2): 293-300. p. http://dx.doi.org/10.1111/j.1432$\underline{1033.1994 . t b 18625 . x}$

NASHIRU O., Zechel D. L., Stoll D., Mohammadzadeh T., Warren R. A. J., Withers S. G. (2001): $\beta$-mannosynthase: Synthesis of $\beta$-mannosides with a mutant $\beta$-mannosidase. Angewandte Chemie, 113 (2): 431-434. p. http://dx.doi.org/10.1002/1521-3757(20010119)113:2<431::AID-ANGE431>3.0.CO;2-Z

Neri D. F. M., Balcão V. M.., Costa R. S., Rocha I. C. A. P., Ferreira E. M. F. C., Torres D. P. M., Rodrigues L. R. M., Jr. L. B., Teixeira J. A. (2009): Galacto-oligosaccharides production during lactose hydrolysis by free Aspergillus oryzae $\beta$-galactosidase and immobilized on magnetic polysiloxane-polyvinyl alcohol. Food Chemistry, 115: 92-99. p. http://dx.doi.org/10.1016/j.foodchem.2008.11.068 
NguYen D. Q., Bujna E., Styevkó G., Rezessy-Szabó J. M., Hoschke Á. (2015): Fungal biomolecules for food industry. In: Vijai K. \& Gupta S. (Szerk): Fungal biomolecules: Sources, applications and recent developments. John Wiley \& Sons, Oxford UK, 11-38. p.

NGUYEN D. Q., Matter F., Hoschke Á., Rezessy-Szabó J., Bhat M. K. (1999): Production, purification and identification of fructooligosaccharides produced by $\beta$-fructofuranosidase from Aspergillus niger IMI 303386. Biotechnology Letters, 21 (3): 183-186. p. http://dx.doi.org/10.1023/A:1005429525865

NGUYEN D. Q., Rezessy-Szabó J. M., Czukor B., Hoschke Á. (2011): Continuous production of oligofructose syrup from Jerusalem artichoke juice by immobilized endo-inulinase. Process Biochemistry, 46 (1): 298-303. p. http://dx.doi.org/10.1016/j.procbio.2010.08.028

NINESS K. R. (1999): Inulin and oligofructose: what are they? The Journal of Nutrition, 129: 1402-1406. p.

OHTSUKA K., Hino S., Fukushima T., Ozawa O., Kanematsu T., Uchida T. (1992): Characterization of levansucrase from Rahnella aquatilis JCM-1683. Bioscience, Biotechnology, and Biochemistry, 56 (9): 1373-1377. p. http://dx.doi.org/10.1271/bbb.56.1373

OKU T., Nakamura S. (2002): Digestion, absorption, fermentation, and metabolism of functional sugar substitutes and their available energy, Pure and Applied Chemistry, 74: 1253-1261. p. http://dx.doi.org/10.1351/pac200274071253

OKuYAMA M., Mori H., Watanabe K., Kimura A., Chiba S. (2002): $\alpha$-Glucosidase mutant catalyzes " $\alpha$ glycosynthase"-type reaction. Bioscience, Biotechnology, and Biochemistry, 66 (4): 928-933. p. http://dx.doi.org/10.1271/bbb.66.928

Palacios H. R., Schwarz P. B., D’Appolonia B. L. (2004): Effects of $\alpha$-amylases from different sources on the firming of concentrated wheat starch gels: relationship to bread staling. Journal of Agricultural and Food Chemistry, 52 (19): 5987-5994. p. http://dx.doi.org/10.1021/jf030384n

Palcic M. M. (1999): Biocatalytic synthesis of oligosaccharides. Current Opinion in Biotechnology, 10: 616-624. p. http://dx.doi.org/10.1016/S0958-1669(99)00044-0

PALMer T. N. (1971): The substrate specificity of acid a-glucosidase from rabbit muscle. Biochemical Journal, 124: 701-711.p.

PANDEY M., Mishra S. (1997): Expression and characterization of Pichia etchellsii $\beta$-glucosidase Escherichia coli. Gene, 190 (1): 45-51. p. http://dx.doi.org/10.1016/S0378-1119(96)00712-3

PanintraruX C., Adachi S., Araki Y., Kimura Y., Matsuno R. (1995): Equilibrium yield of n-alkyl- $\beta$-d-glucoside through condensation of glucose and n-alcohol by $\beta$-glucosidase in a biphasic system. Enzyme and Microbial Technology, 17: 32-40. p. http://dx.doi.org/10.1016/0141-0229(94)00082-3

Park H-E., Park N. H., Kim M-J., Lee T. H., Lee H. G., Jang J-Y., Cha J. (2003): Enzymatic synthesis of fructosyl oligosaccharides by levansucrase from Microbacterium laevaniformans ATCC 15953. Enzyme and Microbial Technology, 32: 820-827. p. http://dx.doi.org/10.1016/S0141-0229(03)00062-0

Park J. P., Bael J. T., You D. J., Kim B. W., Yun J. W. (1999): Production of inulooligosaccharides from inulin by a novel endoinulinase from Xanthomonas sp. Biotechnology Letters, 21: 1043-1046. p. http://dx.doi.org/10.1023/A:1005632526442

PARK N-Y., Baek N-I., Cha J., Lee S-B., Auh J-H., Park C-S. (2005): Production of a new sucrose derivative by transglycosylation of recombinant Sulfolobus shibatae $\beta$-glycosidase. Carbohydrate Research, 340 (6): 1089 1096. p. http://dx.doi.org/10.1016/j.carres.2005.02.003

Parodi A. J. (2000): Protein glucosylation and its role inprotein folding. Annual Review of Biochemistry, 69: 69-93. p. http://dx.doi.org/10.1146/annurev.biochem.69.1.69

Parrou J. L., Jules M., Beltran G., Francois J. (2005): Acid trehalase in yeasts and filamentous fungi: Localization, regulation and physiological function. FEMS Yeast Research, 5 (6-7): 503-511. p. http://dx.doi.org/10.1016/j.femsyr.2005.01.002

Perugino G., Trincone A., Rossi M., Moracci M. (2004): Oligosaccharide synthesis by glycosynthases. Trends in Biotechnology, 22: 31-37. p. http://dx.doi.org/10.1016/j.tibtech.2003.10.008

Pestlin S., Prinz D., Starr J. N., Reilly P. J. (1997): Kinetics and equilibria of condensation reactions between monosaccharide pairs catalyzed by Aspergillus niger glucoamylase. Biotechnoogy and Bioengineering, 56 (1): 922. p. http://dx.doi.org/10.1002/(SICI)1097-0290(19971005)56:1<9::AID-BIT2>3.0.CO;2-O

PILler K., Daniel R. M., Petach H. H. (1996): Properties and stabilization of an extracellular $\alpha$-glucosidase from the extremely thermophilic archaebacteria Thermococcus strain AN 1: enzyme activity at $130{ }^{\circ} \mathrm{C}$. Biochimica et Biophysica Acta - Protein Structure and Molecular Enzymology, 1292 (1): 197-205. p. http://dx.doi.org/10.1016/0167-4838(95)00203-0

Plante O. J., Palmacci E. R., Seeberger P. H. (2001): Automated Solid-Phase Synthesis of Oligosaccharides. Science, 291: 1523-1527. p. http://dx.doi.org/10.1126/science.1057324

Plou F. J., Martín M. T., de Segura A. G., Alcalde M., Ballestoros A. (2002): Glucosyl-transferases acting on starch or sucrose for synthesis of oligosaccharides. Canadien Journal of Chemistry, 80: 743-752. p. http://dx.doi.org/10.1139/v02-104

Pokusaeva K., Fitzgerald G. F., van Sinderen D. (2011): Carbohydrate metabolism in Bifidobacteria. Genes \& Nutrition, 6 (3): 285-306. p. http://dx.doi.org/10.1007/s12263-010-0206-6 
Pokusaeva K., O’Conell-Motherway M., Zomer A., Fitzgerald G. F., van Sinderen D. (2009): Characterization of two novel $\alpha$-glucosidases from Bifidobacterium breve UCC2003. Applied and Environmental Microbiology, 75 (4): 1135-1143. p. http://dx.doi.org/10.1128/AEM.02391-08

Prapulla S. G., Subhaprada V., Karanth N. G. (2000): Microbial production of oligosaccharides: A review. Advances in Applied Microbiology, 47: 299-343. p. http://dx.doi.org/10.1016/S0065-2164(00)47008-5

Prieto P. A. (2005): In vitro and clinical experiences with a human milk oligosaccharides, lacto-N-neotetraose, and fructooligosaccharides. Food and Food Ingredients Japan, 210: 1018-1030.

PURAma R. K., Goyal A. (2005): Dextransucrase production by Leuconostoc mesenteroides. Indian Journal of Microbiology, 45 (2): 89-101. p.

QIANG X., YongLie C., QianBing W. (2009): Health benefit application of functional oligosaccharides. Carbohydrate Polymers, 77: 435-441.p. http://dx.doi.org/10.1016/j.carbpol.2009.03.016

RABIU B. A., Jay A. J., Gibson G. R., Rastall R. A. (2001): Synthesis and fermentation properties of novel galactooligosaccharides by $\beta$-galactosidases from Bifidobacterium species. Applied and Environmental Microbiology, 67 (6): 2526-2530. p. http://dx.doi.org/10.1128/AEM.67.6.2526-2530.2001

RASTALl R. A., Adlard M. W., Bucke C. (1991): Synthesis of hetero-oligosaccharides by glucoamilase in reverse. Biotechnology Letters, 13 (7): 501-504. p. http://dx.doi.org/10.1007/BF01049207

RASTAll R. A., Rees N. H., Wait R., Adlard M. W., Bucke C. (1992): $\alpha$-mannosidase-catalysed synthesis of novel manno-, lyxo-, and heteromanno-oligosaccharides: A comparison of kinetically and thermodynamically mediated approaches. Enzyme and Microbial Technology, 14 (1): 53-57. p. http://dx.doi.org/10.1016/0141-0229(92)90026$\underline{\mathrm{K}}$

REDDY V. P. Beyaz A. (2006): Inhibitors of the Maillard reaction and AGE breakers as therapeutics for multiple diseases. Drug Discovery Today, 11 (13-14): 646-654. p. http://dx.doi.org/10.1016/j.drudis.2006.05.016

10.1016/j.drudis.2006.05.016

REH K-D., Noll-Borchers M., Buchholz K. (1996): Productivity of immobilized dextransucrase for leucrose formation. Enzyme and Microbial Technology, 19 (7): 518-524. p. http://dx.doi.org/10.1016/S0141$\underline{0229(96) 80003-\mathrm{E}}$

REICZIGEL, J., Harnos, A., Solymosi, N. (2010): Biostatisztika, nem statisztikusoknak. Nagykovácsi: Pars Kft.

RezesSY-Szabó J., Nguyen D. Q., Hoschke Á., Braet C., Hajós Gy., Claeyssens M. (2007): A novel thermostable $\alpha$-galactosidase from the thermophilic fungus Thermomyces lanuginosus CBS 395.62/b: Purification and characterization. Bichimica et Biophysica Acta (BBA) - General subjects, 1770 (1): 55-62. p. http://dx.doi.org/10.1016/j.bbagen.2006.06.022

ROBYT J. F., Eklund S. H. (1983): Relative, quantitative effects of acceptors in the reaction of Leuconostoc mesenteroides B-512F dextransucrase. Carbohydrate Research, $121 \quad$ (16): 279-286. p. http://dx.doi.org/10.1016/0008-6215(83)84024-5

ROBYT J. F., Walseth T. F. (1978): The mechanism of acceptor reactions of Leuconostoc mesenteroides B-512F dextransucrase. Carbohydrate Research, 61 (1): 433-445. p. http://dx.doi.org/10.1016/S0008-6215(00)84503-6

RoY D., Daoudi L., Azaola A. (2002): Optimization of galacto-oligosaccharide production by Bifidobacterium infantis RW-8120 using response surface methodology. Journal of Industrial Microbiology and Biotechnology, 29 (5): 281-285. p. http://dx.doi.org/10.1038/sj.jim.7000319

RYCROFT C. E., Jones M. R., Gibson G. R., Rastall R. A. (2001): Fermentation properties of gentiooligosaccharides. Letter of Applied Microbiology, 32 (3): 156-161. p. http://dx.doi.org/10.1046/j.1472$\underline{765 x .2001 .00875 . x}$

SAKO T., Matsumoto K., Tanaka R. (1999): Recent progress on research and applications of non-digestible galactooligosaccharides. International Dairy Journal, 9: 69-80. p. http://dx.doi.org/10.1016/S0958-6946(99)00046-1

SAloheimo M., Kuja-Panula J., Ylösmäki E., Ward M., Penttilä M. (2002): Enzymatic properties and intracellular localization of the novel Trichoderma reesei - glucosidase BGLII (Cel1A). Applied and Environmental Microbiology, 68 (9): 4545-4553. p. http://dx.doi.org/10.1128/AEM.68.9.4546-4553.2002

Saloheimo M., Lund M., Penttilä M. E. (1999): The protein disulphide isomerase gene of the fungus Trichoderma reesei is induced by endoplasmic reticulum stress and regulated by the carbon source. Molecular and General Genetics MGG, 262: 35-45. p. http://dx.doi.org/10.1007/s004380051057

SánChez O., Guio F., Garcia D., Silva E., Caicedo L. (2008): Fructooligosaccharides production by Aspergillus sp. N74 in a mechanically agitated airlift reactor. Food and Bioproducts Processing, 86 (1): 109-115. http://dx.doi.org/10.1016/j.fbp.2008.02.003

SATOH E., Uchimura T., Kudo T., Komagata K. (1997): Purification, characterization, and nucleotide sequence of an intracellular maltotriose-producing $\alpha$-amylase from Streptococcus bovis 148. Applied and Environmental Microbiology, 63 (2): 4941-4944. p.

ScARdovi V. (1981): The genus Bifidobacterium. In: Stan M. P., Stolp H., Triiper H. G., Balows A., Schlegel H. G. (Szerk): The prokaryotes. A handbook on habitats, isolation, and identification of bacteria, Springer-Verlag, New York

SchMID F., Stone B. A., McDougall B. M., Bacic A., Martina K. L., Brownleed R. T. C., Chaie E., Seviour R. J. (2001): Structure of epiglucan, a highly side-chain/branched $(1 \rightarrow 3 ; 1 \rightarrow 6)$ - $\beta$-glucan from the micro fungus Epicoccum nigrum Ehrenb. ex Schlecht. Carbohydrate Research, 331: 163-171. p. http://dx.doi.org/10.1016/S0008-6215(01)00023-4 
Schuman B., Alfaro J. A., Evans S. V. (2007): Glycosyltransferase structure and function. Topics in Current Chemistry, 272: 217-257. p. http://dx.doi.org/10.1007/128_2006_089

Schwab C., Lee V., Sörensen K. I., Gänzle M. G. (2011): Production of galactooligosaccharides and heterooligosaccharides with disrupted cell extracts and whole cells of lactic acid bacteria and bifidobacteria. International Dairy Jounal, 21 (10): 748-754. p. http://dx.doi.org/10.1016/j.idairyj.2011.04.010

SCHWAB C., Vogel R., Gänzlea M. G. (2007): Influence of oligosaccharides on the viability and membrane properties of Lactobacillus reuteri TMW1.106 during freeze-drying. Cryobiology, 55: 108-112. p. http://dx.doi.org/10.1016/j.cryobiol.2007.06.004

SEIBEL J., Beine R., Moraru R., Behringer C., Buchholz K. (2006): A new pathway for the synthesis of oligosaccharides by the use of non-Leloir glycosyltransferases. Biocatalysis and Biotransformation, 24 (1-2): $157-$ 165. p. http://dx.doi.org/10.1080/10242420500538274

SEIBEL J., Moraru R., Götze S. (2005): Biocatalytic and chemical investigations in the synthesis of sucrose analogues. Tetrahedron, 61 (30): 7081-7086. p. http://dx.doi.org/10.1016/j.tet.2005.05.063

Sellers L. A., Allen A., Morris E. R., Ross-Murphy S. B. (1988): Submaxillary mucins. Intermolecular interactions and gel-forming potential of concentrated solutions. Biochemical Journal, 256: 599-607. p.

SEO D. M., Kim S. Y., Eom H. J., Han N. S. (2007): Synbiotic synthesis of oligosaccharides during milk fermentation by addition of leuconostoc starter and sugars. Journal of Microbiology and Biotechnology, 17 (11): 1758-1764. p.

SERVIN A. L., Cocconier M. H. (2003): Adhesion of probiotic strains to the intestinal mucosa and interaction with pathogens. Best Practice \& Research Clinical Gastroenterology, 17: 741-764. p. http://dx.doi.org/10.1016/S15216918(03)00052-0

SETo N. O. L., Compston C. A., Evans S. V., Bundle D. R., Narang S. A., Palcic M. M. (1999): Donor substrate specificity of recombinant human blood group A, B and hybrid A/B glycosyltransferases expressed in Escherichia coli. European Journal of Biochemistry, 259 (3): 770-775. p. http://dx.doi.org/10.1046/j.1432-1327.1999.00086.x

SEzonov G., Joseleau-Petit D., D’Ari R. (2007): Escherichia coli physiology in Luria-Bertani broth. Journal of Bacteriology, 189 (23): 8746-1879. p. http://dx.doi.org/10.1128/JB.01368-07

SHeU D. J., Lio P. J.,Chen S. T., Lin C. T., Duan K. J. (2001): Production of fructooligosaccharides in high yield using a mixed enzyme system of $\beta$-fructofuranosidase and glucose oxidase. Biotechnology Letters, 23: 1499-1503. p. http://dx.doi.org/10.1023/A:1011689531625

ShibuYa T., Aga H., Watanabe H., Sonoda T., Kubota M., Fukuda S., Kurimoto M., Tsujisaka Y. (2003): Transglycosylation of glycosyl residues to cyclic tetrasaccharide by Bacillus stearothermophilus cyclomaltodextrin glucanotransferase using cyclomaltodextrin as the glycosyl donor. Bioscience, Biotechnology, and Biochemistry, 67 (5): 1094-1100. p. http://dx.doi.org/10.1271/bbb.67.1094

SHIN S., Lee Y., Lee C. (2001): The degradation of chitosan with the aid of lipase from Rhizopus japonicus for the production of soluble chitosan. Journal of Biochemistry, 25 (4): 307-321. p. http://dx.doi.org/10.1111/j.17454514.2001.tb00742.x

SINGH R. S., Singh R. P. (2010): Production of fructooligosaccharides from inulin by endoinulinases and their prebiotic potential. Food Technology and Biotechnology, 48 (4): 435-450. p.

SingH S., Scigelova M., Crout D. H. G. (2000): Glycosidase-catalysed synthesis of mannobioses by the reverse hydrolysis activity of $\alpha$-mannosidase: partial purification of $\alpha$-mannosidases from almond meal, limpets and Aspergillus niger. Tetrahedron: Asymmetry, 11 (1): 223-229. p. http://dx.doi.org/10.1016/S09574166(99)00532-7

SMAALI M. I., Michaud N., Marzouki N., Legoy M. D., Maugard T. (2004): Comparison of two $\beta$-glucosidases for the enzymatic synthesis of $\beta-(1-6)-\beta-(1-3)$-gluco-oligosaccharides. Biotechnology Letters, 26 (8): 675-679. p. http://dx.doi.org/10.1023/B:BILE.0000023029.81600.91

SörenSEN S. P. L. (1909): Über die Messung und die Bedeutung der Wasserstoffionenkonzentration bei enzymatischen Prozessen. Biochemische Zeitschrift, 21: 131-200. p.

SRISOMSAP C., Subhasitanont P., Techasakul S., Surarit R., Svasti J. (1999): Synthesis of homo- and heterooligosaccharides by Thai rosewood $\beta$-glucosidase. Biotechnology Letters, 21: 947-951. p. http://dx.doi.org/10.1023/A:1005626209655

StakHelin C., Forsberg L. S., D’Haeze W., Gao M-Y., Carlson R. W., Xie Z-P., Pellock B. J., Jones K. M., Walker G. C., Streit W. R., Broughton W. J. (2006): Exo-oligosaccharides of Rhizobium sp. strain NGR234 are required for symbiosis with various legumes. Journal of Bacteriology, 188 (17): 6168-6178. p. http://dx.doi.org/10.1128/JB.00365-06

STYEvKó G., Styevkó Cs., Hoschke Á., Nguyen D. Q. (2013): Oligosaccharide synthesized by glycosyltransferase activity from Pectinex ultra SP-L enzyme preparation. Acta Alimentaria, 42 (1): 99-106. p. http://dx.doi.org/10.1556/AAlim.42.2013.Suppl.12

SUGAWARA S. (1963): Studies on mode of occurrence of $\alpha$-glucosidase activities in mold (Aspergillus oryzae). Journal of the Faculty of Agriculture, 52 (3): 257-321. p.

SugAwARA S., Nakamura Y., Shimomura T. (1961): Substrate specificity and some properties of crystalline mold maltase. Agricultural and Biological Chemistry, 25 (5): 358-361. p.

SuMER J. B., Howell S. F. (1935): A method of determination of invertase activity. Journal of Biology and Chemistry, 108: 51-54. p. 
SuWASONO S., Rastall R. A. (1996): A highly regioselective synthesis of mannobiose and mannotriose by reverse hydrolysis using specific 1,2- $\alpha$-mannosidase from Aspergillus phoenicis. Biotechnology Letters, 18 (7): 851 856. p. http://dx.doi.org/10.1007/BF00127901

SuzUKI K., Fukumura T., Shibasaki-Kitakawa N., Yonemoto T. (2002): Kinetic model for synthesis of fructosylstevioside using suspended $\beta$-fructofuranosidase. Biochemical Engineering Journal, 10 (3): 207-215. p. http://dx.doi.org/10.1016/S1369-703X(01)00183-8

SvaSTI J., Phongsak T., Sarnthima R. (2003): Transglucosylation of tertiary alcohols using cassava $\beta$-glucosidase. Biochemical and Biophysical Research Communications, 305: 470-475. p. http://dx.doi.org/10.1016/S0006291X(03)00793-9

TAKASAKI Y., Shinoharaa H., Tsuruhisaa M., Hayashia S., Imadaa K. (1991a): Maltotetraose-producing amylase from Bacillus sp. MG-4. Agricultural and. Biological Chemistry, 55 (7): 1715-1720. p.

TAKASAKI Y., Kitajimaa M., Tsurutaa T., Nonguchia M., Hayashia S., Imadaa K. (1991b): Maltotriose-producing amylase from Microbacterium imperial. Agricultural and. Biological Chemistry, 55 (3): 687-692. p.

TAKEWAKI S., Kimura A., Kubota M., Chiba S. (1993): Substrate specificity and subsite affinities of honeybee $\alpha$ glucosidase II. Bioscience, Biotechnology, and Biochemistry, $57 \quad$ (9): 1508-1513. p. http://dx.doi.org/10.1271/bbb.57.1508

TANABE T., Kawase T., Watanabe T., Uchida Y., Mitsutomi M. (2000): Purification and characterization of a 49$\mathrm{kDa}$ chitinase from Streptomyces griseus HUT 6037. Journal of Bioscience and Bioengineering, 89 (1): 27-32. p. http://dx.doi.org/10.1016/S1389-1723(00)88046-9

TANAKA T., Yamamoto S., Ol S., Yamamoto T. (1981): Structures of heterooligosaccharides synthesized by levansucrase. Journal of Biochemistry, 90 (2): 521-526. p.

TANiguCHI N., Honke K., Fukada M. (2002): Handbook of glycosyltransferases and related genes. Springer Verlag, Tokyo

TäUFEL A., Ruttloff H., Täufel K. (1967): Synthesis of maltulose by intestinal $\alpha$-D-glucosidases. Carbohydrate Research, 5 (2): 223-225. p. http://dx.doi.org/10.1016/S0008-6215(00)86047-4

TheVELEIN J. M. (1984): Regulation of trehalose mobilization in fungi. Microbiological Reviews, 48 (1): $42-59$. p.

Thomson L. M., Bates S., Yamazaki S., Arisawa M., Aoki Y., Gow N. A. R. (2000): Functional characterization of the Candida albicans MNT1 mannosyltransferase expressed heterologously in Pichia pastoris. The Journal of Biological Chemistry, 275: 18933-18938. p. http://dx.doi.org/10.1074/jbc.M909699199

TonkovA A. (1998): Bacterial cyclodextrin glucanotransferase. Enzyme and Microbial Technology, 22 (8): 678686. p. http://dx.doi.org/10.1016/S0141-0229(97)00263-9

TorRes D. P. M., Gonçalves M. P. F., Teixeira J. A., Rodrigues L. R. (2010): Galacto-oligosaccharides: production, properties, applications, and significance as prebiotics. Comprehensive Reviews in Food Science and Food Safety, 9: 438-454. p. http://dx.doi.org/10.1111/j.1541-4337.2010.00119.x

Trincone A., Giordano A. (2006): Glycosyl hydrolases and glycosyltransferases in the synthesis of $\begin{array}{lllllll}\text { oligosaccharides. } \quad \text { Current } & \text { Organic } & \text { Chemistry, } & 10 & (10): & 1161-193 . & \text { p. }\end{array}$ http://dx.doi.org/10.2174/138527206777698075

Tsavkelova E. A., Klimova S. Y., Cherdyntseva T. A., Netrusov A. I. (2006): Hormones and hormone-like substances of microorganisms: a review. Applied Biochemistry and Microbiology, 42 (3): 229-235. p. http://dx.doi.org/10.1134/S000368380603001X

TzorTzIS G., Goulas A. K., Gibson G. R. (2005): Synthesis of prebiotic galactooligosaccharides using whole cells of a novel strain, Bifidobacterium bifidum NCIMB 41171. Applied Microbiology and Biotechnology, 68 (3): $412-$ 416. p. http://dx.doi.org/10.1007/s00253-005-1919-0

Tzortzis G., Jay A. J., Baillon M. L. A., Gibson G. R., Rastall R. A. (2003): Synthesis of $\alpha$ galactooligosaccharides with $\alpha$-galactosidase from Lactobacillus reuteri of canine origin. Applied Microbiology and Biotechnology, 63 (3): 286-292. p. http://dx.doi.org/10.1007/s00253-003-1426-0

TyMCzyszyn E. E., Sosab N., Gerbinoa E., Hugoa A., Gómez-Zavagliaa A., Scheborb C. (2012): Effect of physical properties on the stability of Lactobacillus bulgaricus in a freeze-dried galacto-oligosaccharides matrix. International Journal of Food Microbiology, 166: 217-221. p. http://dx.doi.org/10.1016/j.ijfoodmicro.2012.02.008

UMeKAwA M., Li C., Higashiyama T., Huang W., Ashida H., Yamamoto K., Wang L-X. (2010): Efficient glycosynthase mutant derived from Mucor hiemalis endo- $\beta-N$-acetylglucosaminidase capable of transferring oligosaccharide from both sugar oxazoline and natural $N$-glycan. Journal of Biological Chemistry, 285: 511-521. p. http://dx.doi.org/10.1074/jbc.M109.059832

URGINOVITS M. (1980): Zuckeranalyse mit GC, HPLC, DC und enzymatisch- Ein Vergleich der Methoden. Chormatographia, 13: 386-394. p.

VAN DEN Broek L. A. M., Ton. J., Verdoes J. C., Van Laere K. M. J., Voragen A. G. J., Beldman G. (1999): Synthesis of $\alpha$-galacto-oligosaccharides by a cloned $\alpha$-galactosidase from Bifidobacterium adolescentis. Biotechnology Letters, 21 (5): 441-445. p. http://dx.doi.org/10.1023/A:1005542521708

VAN DEN BROEK L., Strujis K., Verdoes J., Beldman G., Voragen A. (2003): Cloning and characterization of two $\alpha$ glucosidases from Bifidobacterium adolescentis DSM20083. Applied Microbiology and Biotechnology, 61 (1): 55-60. p. http://dx.doi.org/10.1007/s00253-002-1179-1 
VAN DER MAAREL M. J. E. C., van der Veen B., Uitdehaag J. C. M., Leemhuis H., Dijkhuizen L. (2002): Properties and applications of starch-converting enzymes of the $\alpha$-amylase family. Journal of Biotechnology, 94 (2): $137-$ 155. p. http://dx.doi.org/10.1016/S0168-1656(01)00407-2

VAN HIJUM S. A. F. T., Kralj S., Ozimek L. K., Dijkhuzien L., Geel-Schutten I. G. H. (2006): Structure-function relationships of glucansucrase and fructansucrase enzymes from lactic acid bacteria. Microbiology and Molecular Biology Reviews, 70 (1): 157-176. p. http://dx.doi.org/10.1128/MMBR.70.1.157-176.2006

VAn LAere K. M. J., Hartemink R., Beldman G., Pitson S., Dijkema C., Schols H. A., Voragen A. G. J. (1999):

Transglycosidase activity of Bifidobacterium adolescentis DSM $20083 \alpha$-galactosidase. Applied

Microbiology and Biotechnology, 52 (5): 681-688. p. http://dx.doi.org/10.1007/s002530051579

VAN LAERE K. M. J., Hartemink R., Bosveld M., Schols H. A., Voragen A. G. J. (2000): Fermentation of plant cell wall derived polysaccharides and their corresponding oligosaccharides by intestinal bacteria. Journal of Agricultural and Food Chemistry, 48 (5): 1644-1652. p. http://dx.doi.org/10.1021/jf990519i

VARKI A. (1993): Biological roles of oligosaccharides: all theories are correct. Glycobiology, 3 (2): 97-130. p. http://dx.doi.org/10.1093/glycob/3.2.97

VÁzQUez M. J., Alonso J. L., Domínguez H., Parajó J. C. (2000): Xylooligosaccharides: manufacture and applications. Trends in Food Science \& Technology, 11 (11): 387-393. p. http://dx.doi.org/10.1016/S09242244(01)00031-0

VIC G., Crout D. H. G. (1995): Synthesis of allyl and benzyl $\beta$-d-glucopyranosides, and allyl $\beta$-D-galactopyranoside from D-glucose or D-galactose and the corresponding alcohol using almond $\beta$-D-glucosidase. Carbohydrate Research, 279: 315-319. p. http://dx.doi.org/10.1016/0008-6215(95)00301-0

VIJN I., Smeekens S. (1999): Fructan: more than a reserve carbohydrate. Plant Phisiology, 120 (2): 351-360. p. http://dx.doi.org/10.1104/pp.120.2.351

VORAGEN A. G. J. (1998): Technological aspects of functional food-related carbohydrates. Trends in Food Science \& Technology, 9: 326-335. p. http://dx.doi.org/10.1016/S0924-2244(98)00059-4

Vulfson E. N., Patel R., Beecher J. E., Andrews A. T., Law B. A. (1990): Glycosidases in organic solvents: I. Alkyl- $\beta$-glucoside synthesis in a water-organic two-phase system. Enzyme and Microbial Technology, 12: 950954. p. http://dx.doi.org/10.1016/0141-0229(90)90115-7

WANG Z., Zhou W., Xu Z., Hu T. (2010): The extraction technology of water-soluble oligosaccharide from Smallanthus sonchifolius. Guizhou Agricultural Science, 2

Wang Q., Graham R. W., Trimbur D., Warren R. A. J., Withers S. G. (1994): Changing enzymatic reaction mechanism by mutagenesis: conversion of a retaining glucosidase to an inverting enzyme. Journal of American Chemical Society, 116: 11594- 11595. p. http://dx.doi.org/10.1021/ja00104a060

WeiJers C. A. G. M., Frassen M. C. R., Visser G. M. (2008): Glycosyltransferase-catalyzed synthesis of bioactive oligosaccharides. Biotechnology Advances, 26: 436-456. p. http://dx.doi.org/10.1016/j.biotechadv.2008.05.001

WestPhal Y., Kühnel S., de Waard P., Hinz S. W. A., Schols H. A., Voragen A. G. J., Gruppen H. (2010): Branched arabino-oligosaccharides isolated from sugar beet arabinan. Carbohydrate Research, 345 (9): 11801189. p. http://dx.doi.org/10.1016/j.carres.2010.03.042

Williams J. S., Withers S. G. (2000): Glycosyl fluorides in enzymatic reactions. Carbohydrate Research, $327: 27-$ 46. p. http://dx.doi.org/10.1016/S0008-6215(00)00041-0

WiN T. T., Isono N., Kusnadi Y., Watanabe K., Obae K., Ito H., Matsui H. (2004): Enzymatic synthesis of two novel non-reducing oligosaccharides using transfructosylation activity with $\beta$-fructofuranosidase from Arthrobacter $\quad$ globiformis. $\quad$ Biotechnology $\quad$ Letters, $26 \quad$ (6): $\quad 499-503 . \quad$ p. http://dx.doi.org/10.1023/B:BILE.0000019557.44196.63

WORMALD M. R., Dwek R. A. (1999): Glycoproteins: glycan presentation and protein stability. Structure, 7: 155160. p. http://dx.doi.org/10.1016/S0969-2126(99)80095-1

XIA W., Liu P., Liu J. (2008): Advance in chitosan hydrolysis by non-specific cellulases. Bioresource Technology, 99 (15): 6751-6762. p. http://dx.doi.org/10.1016/j.biortech.2008.01.011

YAN T-R., Liau J-C. (1998): Synthesis of alkyl $\beta$-glucosides from cellobiose with Aspergillus niger $\beta$-glucosidase II. Biotechnology Letters, 20 (7): 653-657. p. http://dx.doi.org/10.1023/A:1005362305545

YANG R., Xua S., Wanga Z., Yang W. (2005): Aqueous extraction of corncob xylan and production of xylooligosaccharides, LWT - Food Science and Technology, 38: 677-682. p. http://dx.doi.org/10.1016/j.lwt.2004.07.023

YANG Y-1., Wang J-h., Teng D., Zhang F. (2008): Preparation of high-purity fructo-oligosaccharides by Aspergillus japonicus $\beta$-fructofuranosidase and successive cultivation with yeast. Journal of Agricultural and Food Chemistry, 56 (8): 2805-2809. p. http://dx.doi.org/10.1021/jf703586q

Yoshikawa J., Amachi S., Shinoyama H., Fujii T. (2008): Production of fructooligosaccharides by crude enzyme preparations of $\beta$-fructofuranosidase from Aureobasidium pullulans. Biotechnology Letters, 30 (3): 535-539. p. http://dx.doi.org/10.1007/s10529-007-9568-2

Yun J. W., Kim D. H., Uhm T. B., Song S. K. (1997): Production of high-content inulo-oligosaccharides from inulin by a purified endoinulinase. Biotechnology Letters, $19 \quad$ (9): 935-938. p. http://dx.doi.org/10.1023/A:1018366410586 
Yun J. W., Park J. P., Song C. H., Lee C. Y., Kim J. H., Song S. K. (2000): Continuous production of inulooligosaccharides from chicory juice by immobilized endoinulinase. Bioprocess Engineering, 22: 189-194. p. http://dx.doi.org/10.1007/s004490050718

YUN W. J., Choi Y. J., Song C. H., Song S. K. (1999): Microbial production of inulo-oligosaccharides by an endoinulinase from Pseudomonas sp. expressed in Escherichia coli. Journal of Bioscience and Bioengineering, 87 (3): 291-295. p. http://dx.doi.org/10.1016/S1389-1723(99)80034-6

Zhao H., Lu L., Xiao M., Wang Q., Lu Y., Liu C., Wang P., Kumagai H., Yamamoto K. (2008): Cloning and characterization of a novel $\alpha$-galactosidase from Bifidobacterium breve 203 capable of synthesizing Gal- $\alpha-1,4$ linkage. FEMS Microbiology Letters, 285 (2): 178-183. p. http://dx.doi.org/10.1111/j.1574-6968.2008.01246.x

ZHENGYU J., Jing W., Bo J., Xueming X. (2005): Production of inulooligosaccharides by endoinulinases from Aspergillus ficuum. Food Research International, $38 \quad$ (3): $\quad 301-308 . \quad$ p. http://dx.doi.org/10.1016/j.foodres.2004.04.011

ZOPF D., Roth S. (1996): Oligosaccharide anti-infective agents. The Lancet, 347: 1017-1021. p. http://dx.doi.org/10.1016/S0140-6736(96)90150-6

ZWERENZ A. M. (2011): Produktion hochwertiger Oligosaccharide aus nachweisenden Rohstoffen. PhD. értekezés, TU Braunschweig. 


\section{PUBLIKÁCIÓS JEGYZÉK}

\section{Impakt faktoros folyóiratcikk}

Styevkó G., Styevkó Cs., Hoschke Á., Nguyen Q. D. (2013) Novel oligosaccharide synhtetizes by glycosyltransferase activity from Pectinex ultra SP-L enzyme preparation. Acta Alimentaria, 42: 99-106. (IF: 0,427, 2013)

Havas P., Kun Sz., Styevkó G., Slacanac V., Hardi J., Rezessy-Szabó J. (2014) Fruit and Vegetable juice fermentation with Bifidobacteria. Acta Alimentaria, 43: 64-72. (IF: 0,274, 2014)

Szöllősi A., Narr L., Kovács A. G., Styevkó G. (2015) Relationship between kinetics of growth and production of exo-electrons: case study with Geobacter toluenoxydans. Microbiologica et Immunologica Hungarica, 62 (3) (elfogadva közlésre) (IF:0,780, 2014)

\section{Nem impakt faktoros magyar folyóiratcikk}

Styevkó Cs., Styevkó G., Hoschke Á., Nguyen Q. D. (2014) Pectinex ultra enzimkészítmény transzglikozil aktivitása. Élelmiszertudomány Technológia, 2: 22-27.

\section{Idegen nyelvü könyvrészlet}

Nguyen Q. D., Bujna E., Styevkó G., Rezessy-Szabó J.M., Hoschke Á. (2015) Fungal biomolecules for the food industry. Fungal biomolecules: sources, applications and recent developments. Ed.:V.K. Gupta, R.I. MashJohn Wiley \& Sons, UK, 11-39.

\section{$\underline{\text { Hazai konferencia összefoglaló }}$}

Styevkó G., Hoschke Á., Nguyen D.Q. (2013) Maltóz és szacharóz alapú oligoszacharidok biokatalitikus előállítása. 350. Tudományos kollokvium, Budapest

Styevkó G., Rezessy-Szabó J. M., Hoschke Á., Nguyen D.Q. (2012) Frukto-oligoszacharidok alkalmazhatósága szinbiotikum tervezésében. Táplálkozástudományi kutatások II. InnovációTáplálkozás-Egészség- Marketing, Kaposvár

Havas P., Styevkó G., Nguyen D.Q., Rezessy-Szabó J.M. (2010) Probiotikus Bifidobacterium lactis Bb-12 törzs karbohidrolázainak vizsgálata. Probiotikumok-Emberbarát baktériumok Szimpózium, Budapest

Styevkó G., Rezessy-Szabó J.M., Nguyen D. Q. (2009) Bifidobaktériumok inulináz aktivitása.Lippay- Ormos-Vas Tudományos Ülésszak, Budapest

Styevkó G (2009) Szinbiotikum létrehozásának kísérleti megalapozása, (2009) XXIX. OTDK Agrártudományi Szekció, Gödöllő

\section{Nemzetközi konferencia összefoglaló}

Styevkó G., Nguyen V. D., Hoschke Á., Nguyen Q. D. (2014) Mannotriose and manniobiose synthesis by a commercial enzyme preparation from Aspergillus aculeatus. A Magyar Mikrobiológiai Társaság 2014 évi Nagygyülése, Keszthely

Styevkó G., Nguyen V. D., Hoschke Á., Nguyen Q. D. (2014) Oligosaccharide synthesis on different substrates by commercial enzyme preparation from Aspergillus aculeatus. Conference of Chemical Engineering '14, Veszprém 
Styevkó G., Styevkó Cs., Hoschke Á., Nguyen Q. D. (2013) Effect of substrate concentration on synthesis activity of Pectinex ultra SP-L. $4^{\text {th }}$ Central European Forum for Microbiology, Keszthely

Styevkó G., Styevkó Cs., Hoschke Á., Nguyen Q. D. (2013) Effect of maltose and sucrose as bisubstrate systems on glycosyltransferase activity of Pectinex ultra SP-L. Conference of Chemical Engineering '13, Veszprém

Styevkó G., Styevkó Cs., Hoschke Á., Nguyen Q. D. (2012) Effects of substrate concentration and organic-aquous biphasic media on fructosyltransferase activity of Pectinex ultra. A Magyar Mikrobiológiai Társaság 2012 évi Nagygyülése, Keszthely

Styevkó G., Hoschke Á., Nguyen Q. D. (2011) Fructosyl transferase activity of Pectinex ultra for production of novel oligosaccharides. $16^{\text {th }}$ International Congress of the Hungarian Society for Microbiology, Budapest

Styevkó G., Hoschke Á., Nguyen Q. D. (2010) Effects of pH and substrate concentration on biosynthesis of fructo-oligosaccharides. A Magyar Mikrobiológiai Társaság 2010 évi Nagygyülése, Keszthely

\section{Nemzetközi konferencia teljes anyag}

Styevkó G., Styevkó Cs., Hoschke Á., Nguyen Q. D. (2013) Glycosyltransferase and reverse hydrolytic activity of Pectinex ultra SP-L on different substrates. Food Science Conference, Budapest 


\section{Köszönetnyilvánítás}

Hálával tartozom témavezetőmnek Dr. Nguyen Duc Quang egyetemi docensnek, aki szakmai tudásával, hasznos tanácsaival segítette munkámat, támogatott diplomamunkám kezdete óta.

Bátorítása és belém vetett bizalma nélkül nem jutottam volna el ide.

Köszönöm másik témavezetőmnek Prof. Dr. Hoschke Ágoston professzor emeritusnak, hogy segítette kutatómunkám elvégzését, publikációim és értekezésem elkészítését.

Köszönöm hallgatóim Styevkó Csilla, Kilin Ákos, Boross Judit lelkes munkáját, akik hozzájárultak eredményeim megszületéséhez.

Köszönetemet szeretném kifejezni a Sör- és Szeszipari Tanszék dolgozóinak, különösen Rezessyné Dr. Szabó Juditnak, Dr. Bujna Erikának, Dr. Kun-Farkas Gabriellának, Dr. Kun Szilárdnak és Nagy Edinának, a munkám során nyújtott önzetlen segítségükért.

Hálás vagyok doktorandusz társaimnak Dr. Havas Petrának, Farkas Csillának, Fogarasi Attilának, Kovács Attilának, Nguyen Duc Vuongnek, Szöllősi Attilának támogatásukért és hogy kellemes légkört teremtetve segítették munkámat.

Köszönöm Prof. Dr. Hans-Joachim Jördeningnek és Dr. Anja Zwerenznek, hogy lehetővé tették munkámat a Braunschweigi Müszaki Egyetem Müszaki Kémiai Tanszékén, és hozzájárultak a szénhidrát analitikai ismereteim bővítéséhez.

Köszönöm Dr. Gyémánt Gyöngyi egyetemi docensnek, hogy lehetővé tette a MALDI-TOFMS vizsgálatokat a Debreceni Egyetem Szervetlen és Analitikai Kémiai Tanszékén.

Végezetül szeretném megköszönni szüleimnek, testvéreimnek és páromnak a sok-sok türelmet és biztatást. 